\title{
GEOLOGY, GEOCHEMISTRY AND GEOCHRONOLOGY OF THE EAST BAY GOLD TREND, RED LAKE, ONTARIO, CANADA
}

\author{
BY \\ SHAUN VINCENT GALLAGHER
}

\author{
A Thesis \\ Submitted to the Faculty of Graduate Studies $\mathbb{R} \mathbb{R}$

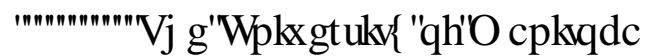 \\ In Partial Fulfillment of the Requirements

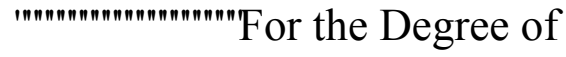 \\ MASTER OF SCIENCE \\ Department of Geological Sciences \\ The University of Manitoba \\ Winnipeg, Manitoba
}

Copyright (C) 201, Shaun Gallagher 


\begin{abstract}
The Red Lake greenstone belt is considered to be one of Canada's premier gold producing regions with the Red Lake Gold Mines having produced $>24$ million ounces of gold to date. The East Bay Trend is a large structural corridor that parallels the East Bay of Red Lake, Ontario and is interpreted to be a manifestation of the regional $\mathrm{D}_{1}$ structure that crosscuts this complexly folded greenstone belt. The southernmost $8 \mathrm{~km}$ of this corridor is host to a variety of small gold deposits that demonstrate an assortment of mineralization styles. This study aims to: (1) better define veining styles and characterize the mineralizing fluids using petrography, fluid inclusions, geochronology and stable isotopes, (2) compare barren and auriferous veins from deposits along the East Bay Trend, and (3) compare the fluid history of the East Bay Trend to the Campbell-Red Lake gold deposit to determine the gold potential along this trend.
\end{abstract}




\section{Acknowledgements}

The author would like to thank Goldcorp Inc., Red Lake Gold Mines for the opportunity of working on this project and for their generous financial and technical assistance throughout. Thanks are also given to the Natural Sciences and Engineering Research Council (NSERC) for providing this project with a Collaborative Research \& Development (CRD) grant, allowing for this research to take place.

Goldcorp, Red Lake Gold Mines Regional Exploration staff provided support throughout this project. Special thanks to Dean Crick and Ken Williamson, who came up with the original idea for the project, and with the initial financial support, Mark Epp for his ongoing support and discussions, and the ongoing support from Chris Osiowy and Bill Paterson. Thanks are also given to Anthony Steistechen, Godfrey Mason-Apps, Lou Chastko, Nicolay Kerkelov and Mitch Dumoulin for their input and support during the summer field seasons. I would also like to thank everyone from the Regional Exploration department including Debra Shushack, Jennifer Brewer, Stephen Brookings, Pascal Chatigny, Sonja Lednicky, Benjamin Howes, Greg Morris and the core shack staff. They were a great help and aided with mapping, sample selection, project information and gave me their guidance while I worked on this study. Also, thanks to the Goldcorp summer students during the 2010 and 2011 field season, their assistance in the field was very much appreciated.

I would like to extend great thanks to my thesis advisors Alfredo Camacho and Mostafa Fayek for aiding me with this thesis and giving me guidance when it was needed. They were very helpful and always willing to review and discuss my work. Thanks is also given to all technical and support staff at the University of Manitoba, including Ravinder Sidhu, Neil Ball, Misuk Yun, Panseok Yang, and Yasir Abdu for their assistance on all of the analytical instruments.

Finally, a big thanks to my friends and family for their support and understanding throughout my research and while I was away during my field seasons. 


\section{Table of Contents}

Abstract
Acknowledgements
Table of Contents
List of Tables
List of Figures
List of Copyrighted Materials for which Permission was Obtained

\section{CHAPTER 1 - INTRODUCTION, History \& OBJECTIVES}

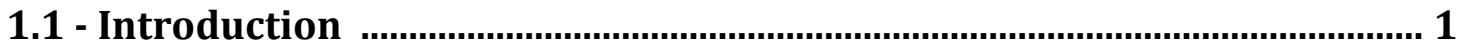

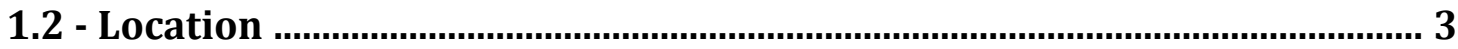

1.3 - Exploration \& Mining History …………………................................... 5

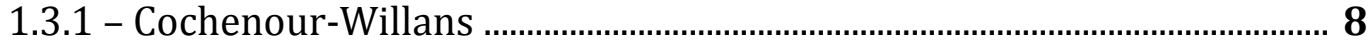

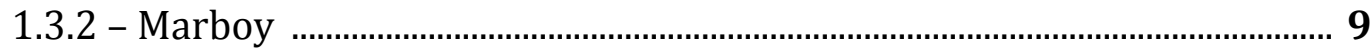

1.3.3 - Chevron Zone ................................................................................................. 10

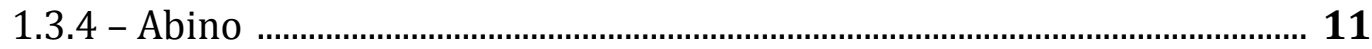

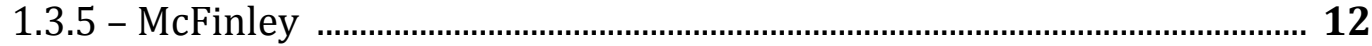

1.4 - Project Objectives ............................................................................... 14

\section{ChAPTER 2 - GeOLOGY}

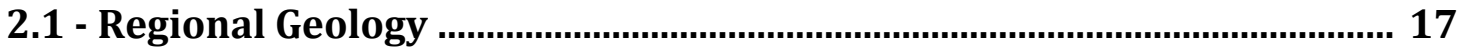

2.1.1 - Mesoarchean Rocks ............................................................................ 17

2.1.2 - Neoarchean Rocks .......................................................................................... 18

2.1.3 - Deformation History ……………………………………………………… 20

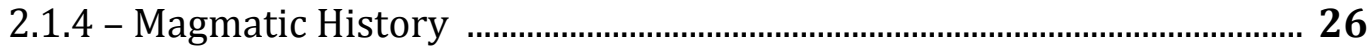

2.1.5 - Thermal History ........................................................................................... 27

2.2 - Geology of the East Bay Area ................................................................. 30

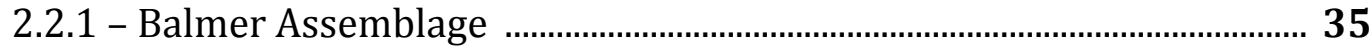

2.2.2 - Balmer Plutonic Suite ............................................................................. 36

2.2.3 - Granitic Plutonic Rocks ................................................................................ 37

2.2.4 - The East Bay Trend ………………………………………................................... 40

\section{Chapter 3 - Methodology}

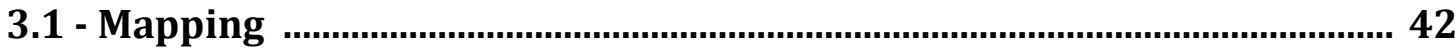

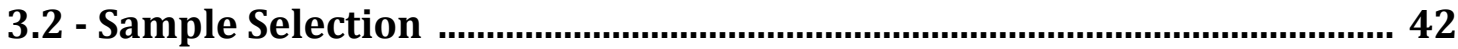

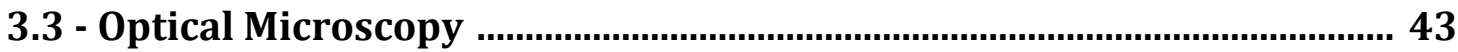

3.4 - Cathodoluminescence .......................................................................... 43

3.5 - Scanning Electron Microscope (SEM) …….............................................. 44

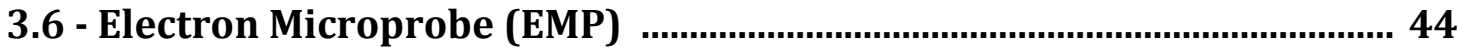


3.7 - X-Ray Diffraction ................................................................................... 46

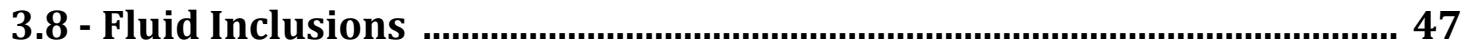

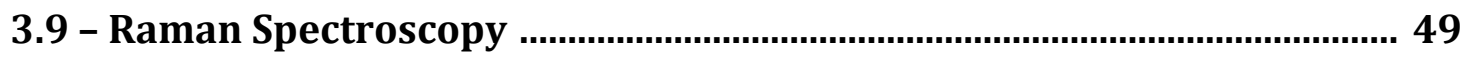

3.10 - Gas Source Mass Spectrometry ........................................................... 50

3.11 - Secondary Ion Mass Spectrometry ……............................................... 51

3.11.1 - Sulphur and Oxygen Isotopes .............................................................. 52

3.11.2 - Measurement of Standards and Unknowns .......................................... 52

3.11.3 - Standard Material Selection and Grain Mount Preparation .............. 53

3.12 - SHRIMP II Geochronology .................................................................... 55

\section{CHAPTER 4 - RESUlTS}

4.1 - Petrography

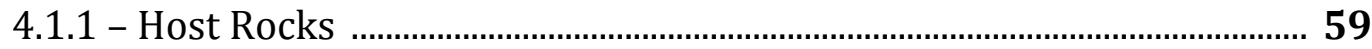

4.1.2 - Early Carbonate Veining ……………………………………………………...60

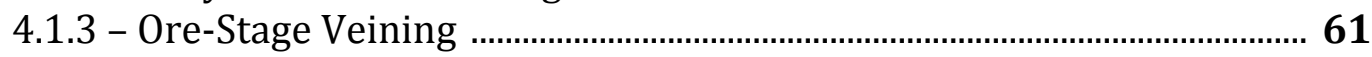

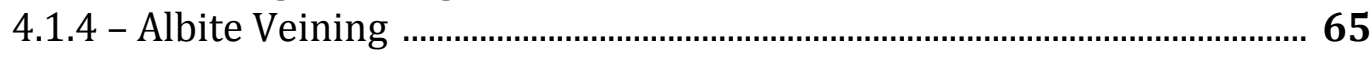

4.1.5 - Tourmaline-bearing Faults (Black Line) ................................................. 66

4.1.6 - Wall Rock Alteration ................................................................................. 67

4.2 - Microthermometric Data ……............................................................... 70

4.2.1 - Tuckers Knob Area ...................................................................................... 73

4.2.2 - Marboy (McMarmac) Area .......................................................................... 77

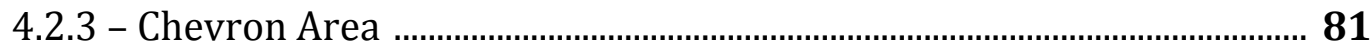

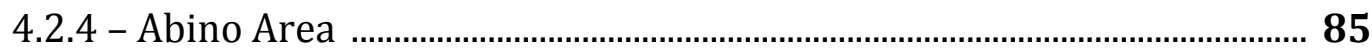

4.2.5 - McFinley Area - Duchesne GAZ Zone ........................................................ 88

4.2.6 - Cochenour Area ...........................................................................................90

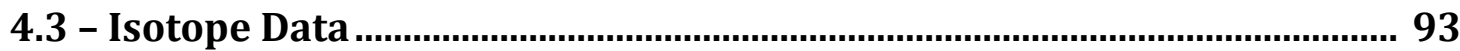

4.3.1 $-\delta^{13} \mathrm{C} \& \delta^{18} \mathrm{O}$ of Carbonate Veins ............................................................. 93

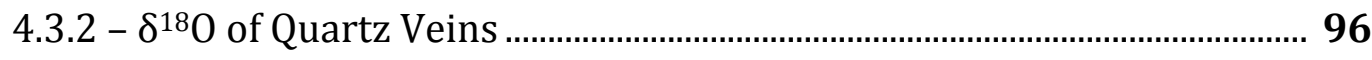

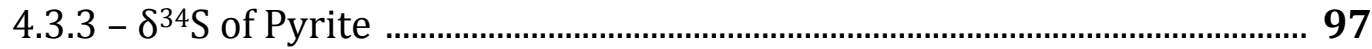

4.3.4 - $\delta^{18} \mathrm{O}$ of Quartz-Tourmaline Veins ......................................................... 100

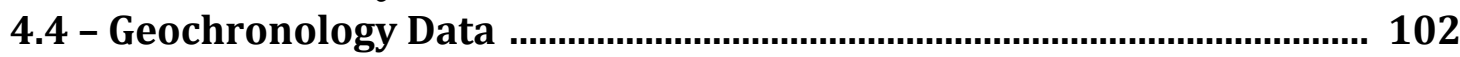

4.4.1 - U-Pb Geochronology using SHRIMP II ................................................... 102 


\section{ChAPTER 5 - DiscuSSION}

5.1 - Mechanisms for Gold Deposition ........................................................... 104

5.1.1 - Immiscibility ........................................................................................ 105

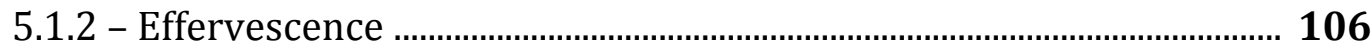

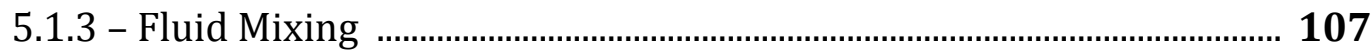

5.1.4 - Tuckers Knob ........................................................................................... 108

5.2 - Microthermometry and Gold Deposition ............................................ 109

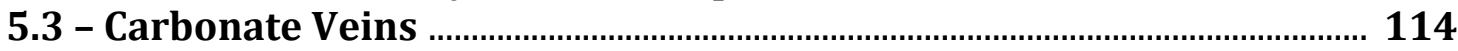

5.3.1 - Carbon Sources and Isotopic Composition ........................................... 116

5.4 - Early Quartz Veins ............................................................................................ 119

5.5 - Ore-Stage Quartz Veins ………………………………………………… 120

5.5.1 - Source and Isotopic Signature of Auriferous Quartz Veins .............. 121

5.5.2 - Sulphur Source ......................................................................................... 123

5.6 - Post-Ore Veins ……………………………………………………………... 125

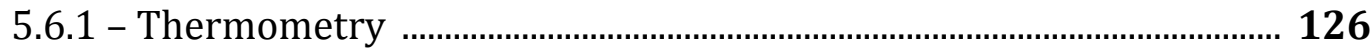

5.7 - East Bay Gold Deposits and Genetic Models ........................................... 127

5.8 - Comparison of the East Bay Trend to the Red lake Gold Mines, and Other World-Class Gold Deposits............................................................................................ 133

\section{ChAPTER 6 - DisCUSSION \& FUTURE WORK}

6.1 - Conclusions

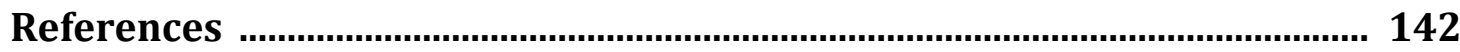

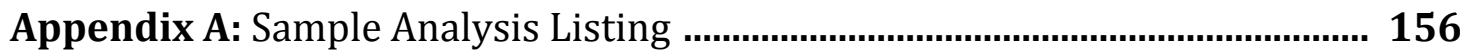

Appendix B: XRD Analyses ......................................................................... 161

Appendix C: Electron Microprobe Analyses ................................................... 169

Appendix D: Fluid Inclusion Data ..................................................................... 178

Appendix E: Stable Isotope Data - Gas-Source Mass-Spectrometry ................. 188

Appendix F: Stable Isotope Data - SIMS ………......................................... 190

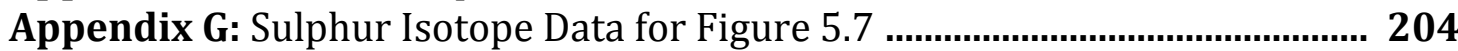

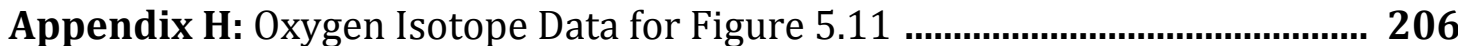

Appendix I: SHRIMP II Geochronology Data ....................................................... 209 


\section{List of Tables}

Table 1.1 - Historical and current gold production in Red Lake.................................... 7

Table 2.2 - Summary of the geological units in the Red Lake greenstone belt ..... 20

Table 2.3 - Timing of deformation and metamorphism in eastern Red Lake ........ 29

Table 2.4 - Summary the major intrusive bodies and minor dykes/stocks ............ 39

Table 3.1 - Elements and respective standards for EMPA analysis............................ 46

Table 4.1 - Carbonate vein $\delta^{18} \mathrm{O}$ and $\delta^{13} \mathrm{C}$ values ......................................................... 94

Table 4.2 - Average $\delta^{18} \mathrm{O}$ values from deposits and showings along the EBT ...... 97

Table 4.3 - Average $\delta^{34} \mathrm{~S}$ values from pyrite grains along the EBT ............................ 98

Table 4.4 - Quartz-tourmaline vein equilibrium temperatures and $\delta{ }^{18} 0$ value of

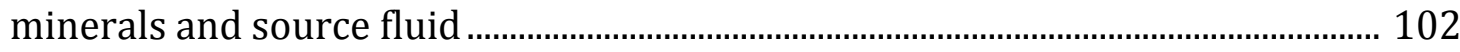

Table 5.1 - Summary of fluid inclusion and $\delta^{18} \mathrm{O}$ values from vein samples ....... 112

Table 5.2 - Characteristics of known gold deposit styles ........................................ 133

Table 5.3 - Characteristics of gold deposits $>20,000 \mathrm{oz}$ in the Red Lake camp with

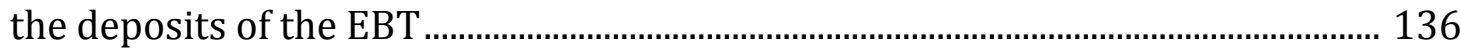

Table 5.4 - Geological characteristics of world-class gold deposits compared to the deposits of the EBT 


\section{List of Figures}

Figure 1.1 - Map of Ontario with location of Red Lake ................................................ 4

Figure 1.2 -Simplified map of Red Lake with Mine Trend and East Bay Trend ..... 5

Figure 1.3 - Map of the East Bay Deposit Occurences ................................................. 14

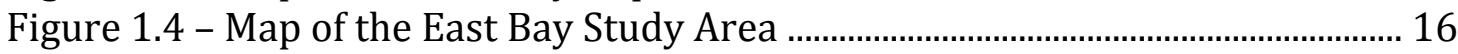

Figure 2.1 - Geological map of Superior Province and subprovince divisions ..... 19

Figure 2.2 - Red Lake Greenstone Belt regional geologic map .................................... 24

Figure 2.3 - Structural evolution of the Red Lake greenstone belt ............................ 25

Figure 2.4 - Red Lake Greenstone Belt airbourne magnetics highlighting the

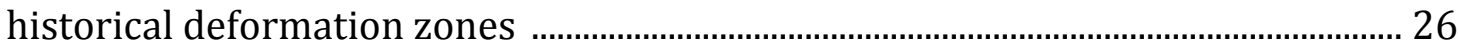

Figure 2.5 - Metamorphic map of the Red Lake Belt..................................................... 30

Figure 2.6 - Geology Map for the East Bay Study Area ……………………………… 32

Figure 3.1 - Depression of freezing point of water ....................................................... 49

Figure 4.1 - Generalized paragenesis for the East Bay Trend .................................... 58

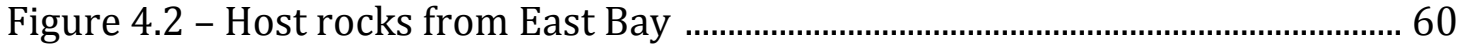

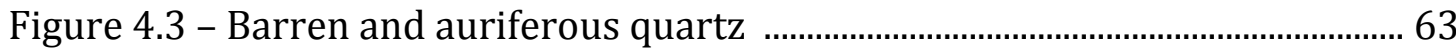

Figure 4.4 - Variety of Vein types from the East Bay Trend ........................................ 64

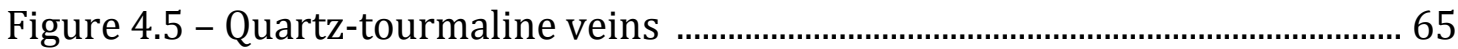

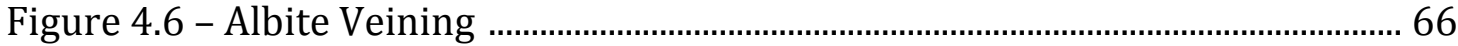

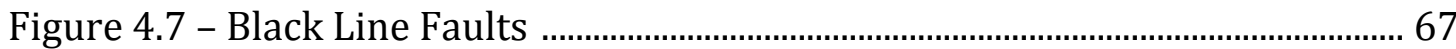

Figure 4.8 - Carbonate alteration zones in the Red lake Belt ...................................... 69

Figure 4.9 - Alteration zone mineralogy and fabric .................................................... 70

Figure 4.10 - Image of primary and secondary fluid inclusions ............................... 71

Figure 4.11 - Airphoto and Map of Tuckers Knob outcrop ...................................... 74

Figure 4.12 - Variable liquid-vapor ratios for inclusions from Tuckers Knob....... 75

Figure 4.13 - Tuckers Knob microthermometric graphs .................................... 76-77

Figure 4.14 - Marboy microthermometric graphs ..................................................... 79

Figure 4.15 - Variable liquid-vapor ratios for inclusions from Marboy ........... 80-81

Figure 4.16 - Chevron microthermometric graphs ............................................... 83-84

Figure 4.17 - Abino microthermometric graphs ................................................... 86-87

Figure 4.18 - McFinley/Duchesne microthermometric graphs .......................... 89-90

Figure 4.19 - Cochenour microthermometric graphs .......................................... 92-93

Figure 4.20 - Map of carbonate vein sample locations .............................................. 95

Figure $4.21-\delta^{13} \mathrm{C}$ vs $\delta^{18} \mathrm{O}$ plot of carbonate samples ............................................... 96

Figure 4.22 - Sulphide occurrence .............................................................................. 98

Figure 4.23 - Photomicrograph of pyrite with SIMS analytical points...................... 99

Figure $4.24-\delta \delta^{34}$ values of pyrite grains from the East Bay Trend ........................ 100

Figure 4.25 - Titanite grains ........................................................................................ 103

Figure 4.26 - Concordia diagram for vein titanite grains grains ............................. 103

Figure 5.1 - Temperature vs salinity plot for East Bay relative to known fields for gold deposits 
Figure 5.2 - Importance of ore depositional mechanisms for Archean lode-gold

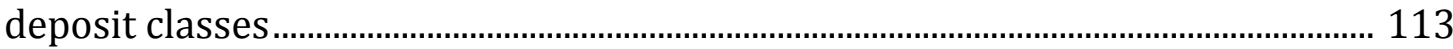

Figure 5.3 - Timing of gold mineralization in the Red Lake camp ................. 115-116 Figure 5.4 - Carbonates from Red Lake relative to carbonate from the Superior and Slave provinces 117

Figure 5.5 - Raman spectrum of the vapor phase of an aqueous inclusion ........ 119

Figure $5.6-\delta^{18} 0$ values from quartz veins from the East Bay Trend .................... 122

Figure $5.7-\delta^{34} \mathrm{~S}$ for East Bay pyrite with known ranges of magmatic sulphur 124

Figure $5.8-\delta^{34} S$ values for East Bay relative to other gold deposit sulphides .. 125

Figure 5.9 - Generalized sequence of fluid events in the East Bay.......................... 126

Figure 5.10 - Schematic representation of crustal environments for hydrothermal

gold deposits 130

Figure $5.11-\delta^{18} 0$ range for auriferous quartz East Bay compared to well-known epithermal and mesothermal deposits from around the world 135 


\section{List of Copyrighted Material for which Permission was Obtained}

Figure 1.1 - (After Dumoulin, 2009) ............................................................................. 4

Figure 1.2 - (After Sanborn-Barrie et al., 2004) ............................................................... 5

Table 1.1 - (After Lichtblau et al., 2012) ……................................................................. 7

Figure 1.4 - (After Sanborn-Barrie et al., 2004) ............................................................. 16

Figure 2.1 - (After Stott et al., 2010 and Stott \& Corfu, 1991) ..................................... 19

Figure 2.2 - (After Goldcorp Canada Inc.) ...................................................................... 24

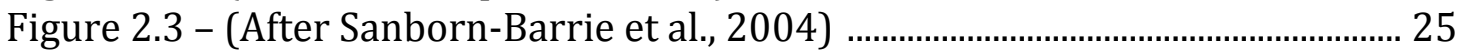

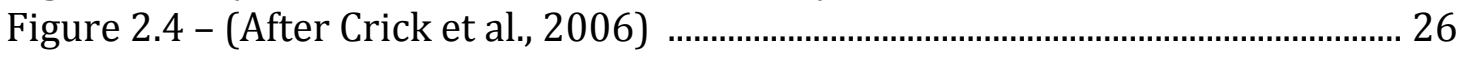

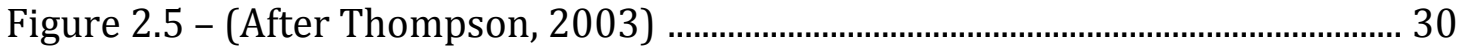

Figure 2.6 - (After Sanborn-Barrie et al., 2004) ............................................................ 32

Figure 5.2 - (After Mikucki, 1998) ............................................................................. 113

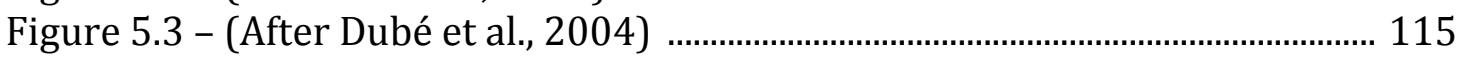

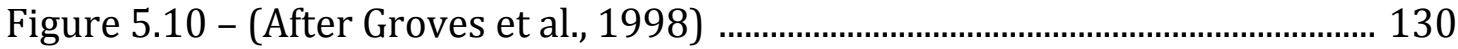

Figure 5.11 - (After Groves et al, 1998) ...................................................................... 135 


\section{CHAPTER 1 - INTRODUCTION}

\subsection{Introduction}

Greenstone belts older than 2.5 Ga represent a major source of gold accounting for approximately $60 \%$ of the World's cumulative gold production (Robert et al., 2005). In Canada, mesothermal (also termed mesozonal - Groves et al., 2003) greenstone-hosted (also known as quartz-carbonate vein, orogenic and lode gold) deposits are mainly located in the Archean greenstone belts of the Superior and Slave provinces and account for close to $20 \%$ of the World's cumulative gold production (Poulsen et al., 2000; Dubé and Gosselin, 2007).

These deposits generally form at intermediate depths within the crust $(\sim 5-10$ $\mathrm{km})$ and have significant vertical extent ( $\sim 2 \mathrm{~km}$ average). Lode gold deposits are typified by large vein systems (open space filling) with associated wall-rock alteration. This type of mineralization is classified as shear-zone hosted vein deposits and often contains quartz-carbonate veins that crosscut these shear-zones. These veins generally contain quartz with lesser quantities of albite, calcite, chlorite, sericite and tourmaline (Roberts, 1987). Sulphide minerals rarely comprise more than $5 \%$ of the vein, with pyrite/pyrrhotite as the dominant sulphide accompanied with lesser amounts of arsenopyrite, chalcopyrite and stibnite. Wallrock adjacent to the veins characteristically contains the mineral assemblage from the veins, as well as altered host rock minerals (Roberts, 1987). Ore grade gold is typically confined to the veins, where it occurs as free gold in quartz or associated with iron-sulphides. However, some deposits have gold concentrated along the adjacent wallrocks 
(Roberts, 1987). These deposits fall within the greenstone vein category of gold deposits, as defined by Dubé \& Gosselin (2007).

Various gold mineralization styles occur in Archean deposits, some of which include: quartz-carbonate veins, massive sulphide deposits, sulphide replacement of carbonate-quartz veins or banded iron formations (BIF), and stockwork or silicaflooded zones. Small deposits typically form from a single mineralization event, whereas many of the larger World Class deposits form due to the combination of multiple mineralizing events and complex structures that channel metal-rich fluids (Roberts, 1987). This is demonstrated in the Red Lake camp, which hosts a variety of deposits that each posses unique veining and metal characteristics, making it one of the richest gold camps in the world.

Red Lake, Ontario, is one of Canada's principal gold-producing regions and to date has produced over 27 million ounces of gold, most of which comes from the Red Lake Gold Mines (Lichtblau et al., 2012). In the Red Lake district, gold exploration has historically focused along an E-W corridor of variably deformed rocks (Dumoulin, 2009). This corridor is known as the 'Mine Trend' as it hosts the largest of the mines, leaving the NE-SW corridor (East Bay trend) reasonably under explored relative to the mine trend. Recent exploration of the East Bay trend (EBT) has yielded exciting results and may contain important gold reserves (Dumoulin, 2009). 


\subsection{Location}

The Red Lake Greenstone belt (RLGB), located in northwestern Ontario, represents the western portion of the Uchi Subprovince of the Archean Superior Province (further discussed in chapter 2). The belt is $48 \mathrm{~km}$ long, $26 \mathrm{~km}$ wide, and cover an area of $\sim 880 \mathrm{~km}^{2}$ (Sanborn, 1987).

The village of Cochenour is situated $182 \mathrm{~km}$ north of Vermillion Bay on Ontario Highway 105 and is also accessed by plane from Winnipeg and Thunder Bay (Fig 1.1). The EBT begins near the village of Cochenour, $6 \mathrm{~km}$ northeast of the town of Red Lake. An $8 \mathrm{~km}$ section of this trend that begins at Cochenour and continues northeast parallel to the East Bay of Red Lake is the focus of this project (Fig. 1.2), as there are a number of deposits, showings and former mines within this area. 


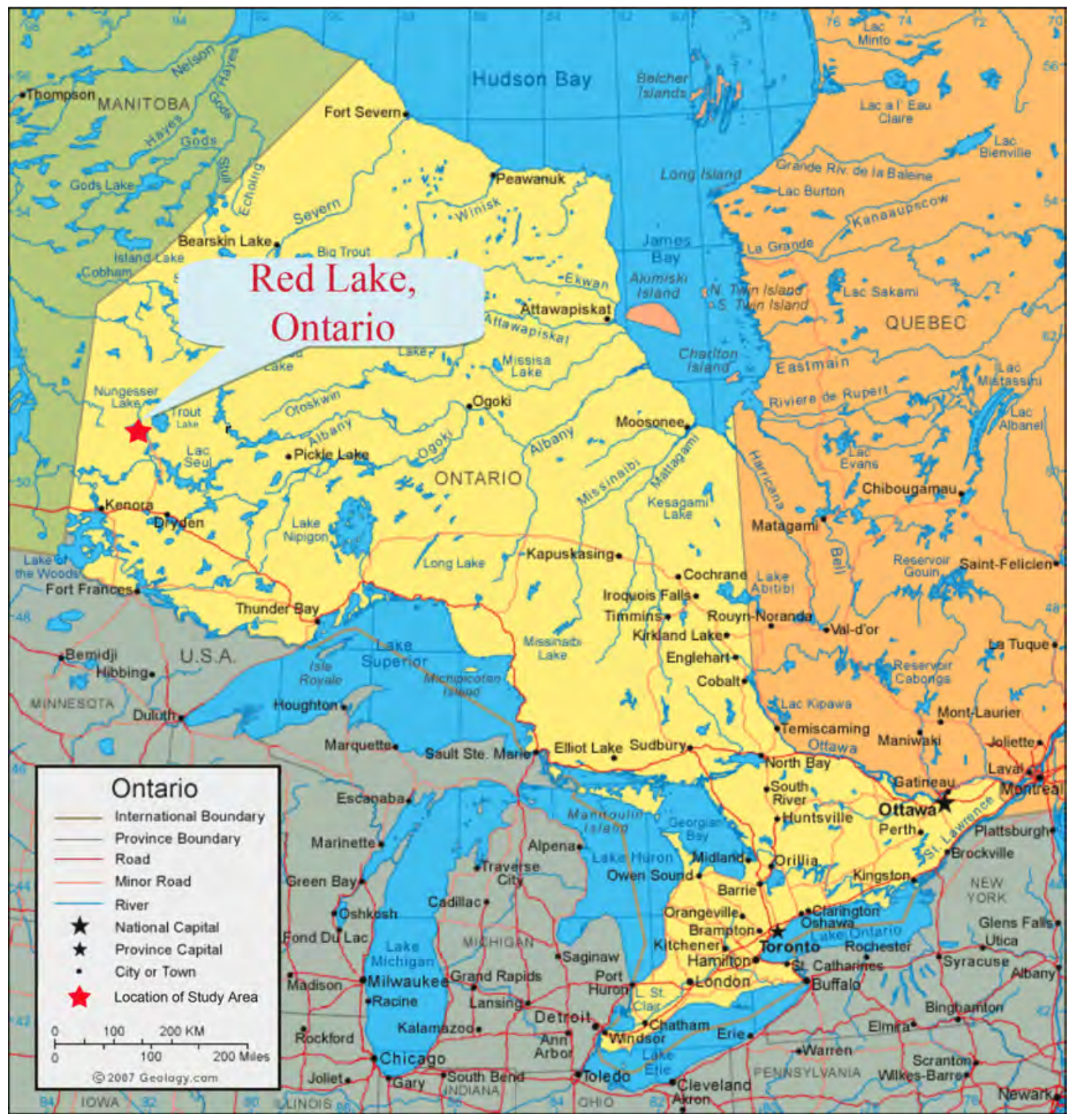

Figure 1.1 - Map of Ontario indicating the location of Red Lake, Ontario (in red) with roads and major cities indicated (modified after Dumoulin, 2009). 


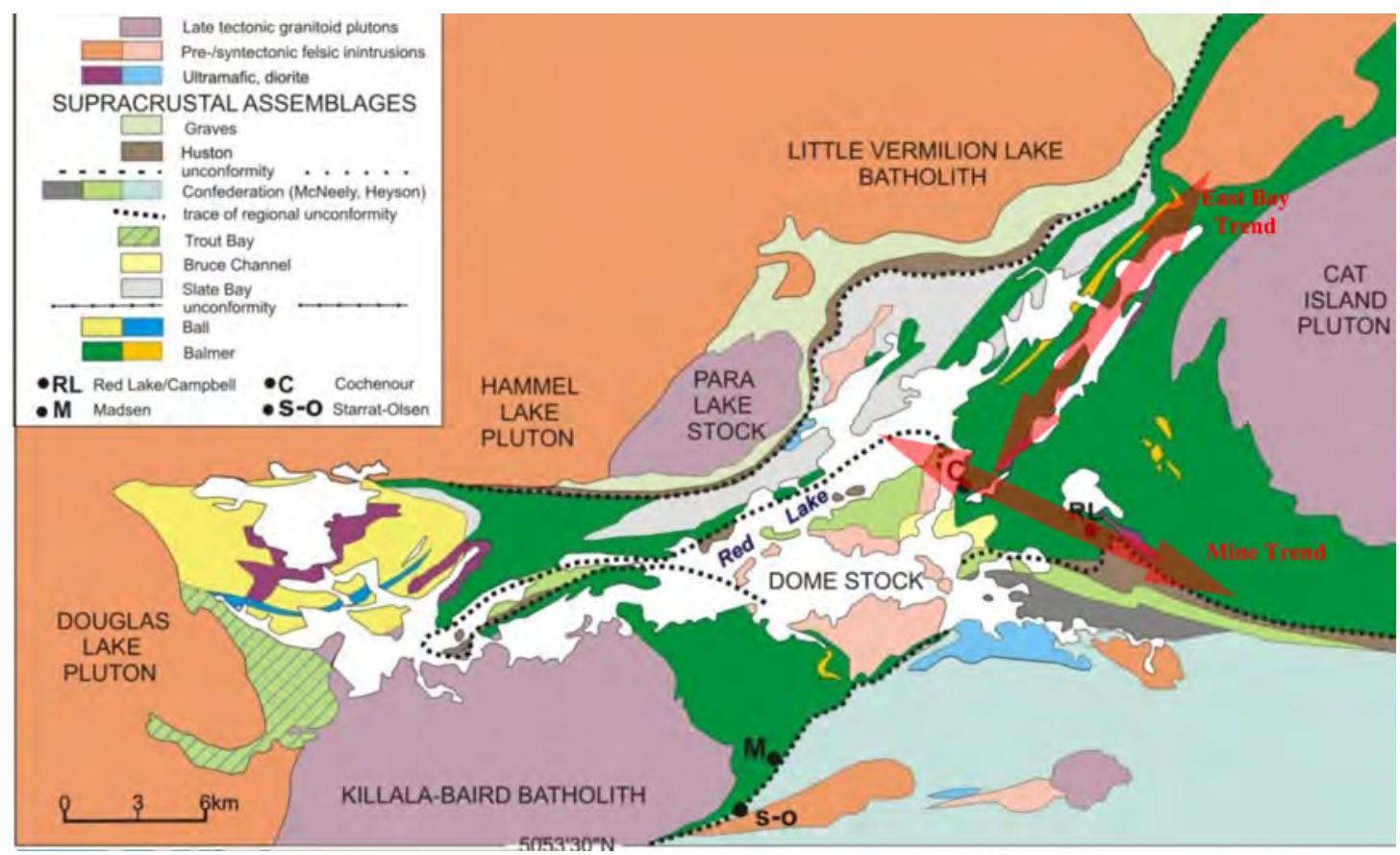

Figure 1.2 - Simplified geological map of the RLGB with the 'Mine Trend' and 'East Bay Trend' indicated. RL = Red Lake/Campbell; $\mathrm{C}=$ Cochenour; $\mathrm{M}=$ Madsen; $\mathrm{S}-\mathrm{O}=$ Starratt-Olsen (Modified after Sanborn-Barrie et al., 2004).

\subsection{Exploration and Mining History}

Prospecting in the Red Lake region began in the late 1800's after small traces of gold were noted when the first geological map was produced in 1894 by D.B. Dowling of the Geological Survey of Canada. This was one of the only geological documents available until further exploration occurred in the 1920's (Horwood, 1940). Gold was first discovered in the area in 1897, however the first gold rush did not begin until 1926. This first rush uncovered gold zones within the townsite of Red Lake but most exploration endevours were unsuccessful at this time. The belt did not see much success until the second gold rush numerous discoveries were made in the eastern portion of the belt in the late 1930's. The discovery of free gold on the shore of Balmer Lake led to drilling that identified many gold intersections in 
what has become the Balmertown area (Ferguson, 1966). These discoveries led to the founding of the Campbell and Dickenson (now Red Lake) mines, which began full production in 1949, and are still currently in production as one large mining operation known as the Red Lake Gold Mines (RLGM). Although the Cochenour mine opened in 1939, the regional structures of the "Mine Trend" and "East Bay Trend" were not yet recognized. Extensive mining would continue throughout the RLGB for decades with limited understanding of the geology or structures (Horwood, 1940). As of 2011, the Red Lake district has cumulatively produced 26,825,793 troy ounces of gold from 29 mines over the last 80 years (Lichtblau et al, 2012). The historical gold production of the Red Lake district is summarized in Table 1.1. Further details on the history and geology of the Red Lake greenstone belt can be found in Horwood (1940), Ferguson (1966), Sanborn-Barrie et al. (2000), and Sanborn-Barrie et al. (2001).

During the past 90 years, several deposits and mines were active throughout the EBT (Fig. 1.3). A summary of exploration and mining on each respective property is listed below, for a more detailed history please see Horwood (1940) or Ferguson (1966). 
Table 1.1 - Historical and current gold production in the Red Lake district (Lichtblau et al., 2012)

\begin{tabular}{|c|c|c|c|c|}
\hline \multirow{2}{*}{ Mine } & \multirow{2}{*}{ Years of Production } & \multirow{2}{*}{$\begin{array}{c}\text { Ore Milled } \\
\text { (Short Tons) }\end{array}$} & \multicolumn{2}{|c|}{ Gold Produced } \\
\hline & & & Troy Ounces & Ounces per Ton \\
\hline Red Lake Gold Mines & 2006-present ${ }^{(1)}$ & 4711640 & 3870690 & 0.822 \\
\hline Campbell Mine & $1949-2006^{(2)}$ & 19944241 & 11216443 & 0.564 \\
\hline Goldcorp (Dickenson) & $1948-2006^{(3)}$ & 9606894 & 5962948 & $0.621^{(4)}$ \\
\hline Madsen & $1938-1976,1997^{(5)}-1999$ & 8678143 & 2452388 & $0.283^{(6)}$ \\
\hline Cochenour-Willans & 1939-1971 & 2311165 & 1244279 & $0.538^{(7)}$ \\
\hline McKenzie Red Lake & $1935-1966$ & 2353833 & 651156 & 0.277 \\
\hline Howey & $1930-1941,1957^{(8)}$ & 4630779 & 421592 & $0.091^{(9)}$ \\
\hline Hasaga & $1938-1952$ & 1515282 & 218213 & 0.144 \\
\hline Starratt Olsen & $1948-1956$ & 907813 & 163990 & 0.181 \\
\hline Berens River & $1939-1948$ & 560607 & 157341 & 0.281 \\
\hline Uchi & $1939-1943$ & 757074 & 114467 & 0.151 \\
\hline Jason (Argosy) & $1934-1952$ & 276573 & 101875 & 0.368 \\
\hline H.G. Young & $1960-1963$ & 288179 & 55244 & 0.192 \\
\hline Sachigo River & $1938-1941$ & 46457 & 52560 & 1.131 \\
\hline McMarmac & $1940-1948$ & 152978 & 45246 & 0.296 \\
\hline Gold Eagle & $1937-1941$ & 180095 & 40204 & 0.223 \\
\hline Jackson Manion & $1934-1940$ & 105357 & 27142 & 0.258 \\
\hline Red Lake Gold Shore & $1936-1938$ & 86333 & 21100 & 0.244 \\
\hline Hudson Patricia & $1936-1937$ & 11228 & 1857 & 0.165 \\
\hline Buffalo & 1981-1982 & 31986 & 1656 & 0.052 \\
\hline Abino & $1985-1986$ & 2733 & 1397 & 0.511 \\
\hline Lake Rowan & $1986-1988$ & 13023 & 1298 & 0.100 \\
\hline Mount Jamie & 1976 & 972 & 377 & 0.388 \\
\hline Kostynuk Brothers & $1963-1966$ & 577 & 1126 & 1.951 \\
\hline Bobjo & 1929 & N/A & $362^{(10)}$ & N/A \\
\hline Bathurst & $1927-1937$ & 562 & 307 & 0.546 \\
\hline Red Summit & $1935-1936$ & 591 & 277 & 0.469 \\
\hline Sol d'Or & $1933-1936$ & 458 & 258 & 0.563 \\
\hline McFinley & 1987 & N/A & N/A & N/A \\
\hline \multicolumn{2}{|c|}{ TOTAL } & 57175573 & 26825793 & 0.469 \\
\hline
\end{tabular}

Notes: (1) Includes total production from the Red Lake complex from January 1, 2006, and production from the Campbell complex subsequent to May 12, 2006, the date of acquisition.

(2) Includes production figures under Placer Dome (CLA) Ltd., to May 12, 2006.

(3) For 1997, 1998 and 1999, no production due to strike by unionized employees.

(4) From 1970, includes production from Robin Red Lake.

(5) Includes clean up of ore and materials from the mine site.

(6) Historic grade, actual grade for 1999 was 0.14 ounce per ton gold.

(7) Includes production from Annco and Wilmar properties.

(8) Continuous production 1930 to 1941 ; includes 268 ounces recovered from clean up in 1957.

(9) The ore mined at Howey, before sorting, totalled 5158376 tons.

The average production from run-of-mine ore was therefore 0.0817 ounce per ton gold.

(10) Not included in total production figure.

N/A Data not available. 


\subsection{1 - Cochenour-Willans}

The Cochenour-Willans Mine became the seventh gold-producer in the RLGB on December 2, 1939. Thirteen original claims were staked during the gold rush of 1926-27 by W.M. Cochenour and his partners, forming the Cochenour Willans Syndicate in 1928 (Horwood, 1940). In 1932, Ventures Ltd. optioned the property and designed a surface drilling program. From 1934-35, Hollinger Consolidated Gold Mines Ltd. optioned the property sinking a 312-foot shaft and established levels at the 150- and 275-foot horizons. In 1939, the company shipped 4,959 tons of ore to the mill at the adjacent Gold Eagle Mines. This produced 2,360 ounces of gold at a grade of 0.48 ounces per ton. Hollinger Consolidated Gold Mines Ltd eventually built their own mill at the Cochenour-Willans mine (Horwood, 1940). Production was carried out by Cochenour-Willans from 1939 to 1971 and produced 2.31 million tons of ore containing 1.24 million ounces of gold for a head grade of 0.538 ounces per ton (Holt, 1988). The mine consisted of 2 shafts; the main shaft to 2,600 feet and the number 2 shaft to 475 feet.

Production ceased in 1971 due to increases in costs and the depletion of known ore, but the adjacent Wilmar property continued producing until 1975 (Holt, 1988). The mine has had many owners, including Wilanour Resources, Esso Minerals Canada, and Inco Gold Inc. and most recently Goldcorp Inc., who acquired the property in 1998 (Goldcorp, 2012). Little work was carried out on the property until 2002, when exploration drilling began. Drilling has increased every year, reaching over 15,000 metres in 2007. In 2008, Goldcorp Inc. acquired the Bruce Channel deposit from Gold Eagle Mines Ltd., which is adjacent to the CochenourWillans mine and is considered to be a down-dip extension of the same ore system. 
Goldcorp is currently rehabilitating and drilling the Cochenour-Willans mine with expected production to recommence in 2014 (Goldcorp, 2012).

\subsection{2 - Marboy}

The McMarmac mine became the eighth gold producer in the RLGB on October $18,1940$. It produced a total of 121,368 tons of milled ore (Ferguson, 1966). Exploration on the McMarmac mine property began in the 1920's and continued through 1927, when the Nortricia Mining Company Ltd. completed diamond drilling and underground exploration using an abandoned shaft (Horwood, 1940). Red Mammoth Gold Ltd. acquired the company in 1928 and completed a 2-compartment shaft to a depth of 75 feet and drove a 50-foot crosscut on the 65-foot level. In 1933 Margaret Mines Ltd. secured the property and deepened the shaft to 188 feet with up to 300 feet of exploration drifting along the 175 foot level (Horwood, 1940). By 1937 Margaret Mines Ltd began upgrading to a 3-compartment shaft. That same year 20 drill holes totaling 3,133 feet were drilled by Richmac Gold Mines on the adjacent property intersecting a 380-foot section of the carbonate zone, which had an average width of 23 feet (Horwood, 1940). In 1939, McKenzie Red Lake Gold Mines Ltd. optioned the property and deepened the 3-compartment shaft to a depth of 310 feet, where a 300-foot level was established. By 1940 McMarmac Red Lake Gold Mines was incorporated and acquired the property. They deepened the shaft to 475 feet before officially opening the mine and constructed a 75 ton per day mill (Horwood, 1940). Eventually the operation expanded to 5 working mine levels at $150,300,450,600$ and 750 feet, but ore grades decreased at the 600 - and 750 -foot levels (Ferguson, 1966). The mineralized carbonate veins were approximately 23 
feet wide (reaching nearly 40 feet in areas), had a length of approximately 2,400 feet, but only approximately 655 feet was mined. In most areas the veins narrowed to 5 feet or completely pinched out (Ferguson, 1966). In 1949 a 2,800-foot exploration crosscut was established between the 750 -foot level and the 450 -foot level to investigate the down-dip extension of the ore bodies. The mine ceased production in 1950 due to poor drilling results and still remains inactive.

\subsection{3 - Abino}

The Abino area surrounds the southern tip of East Bay which is the easternmost extension of Red Lake (Fig. 1.3). Within East Bay, between Kaymac Point and Abino Point, auriferous quartz veins were discovered hosted in a granodiorite intrusion (Mason-Apps, 2002).

Work began in the Abino area in 1939. It was not until the late 1950's that a small shaft was sunk at Abino Point (Mason-Apps, 2002). Drilling determined that mineralized zones were narrow, irregular, discontinuous and therefore subeconomic. These zones were composed of narrow, erratic quartz stringers that were often $1 \mathrm{~cm}$ wide. The shaft was later sealed in the early 1960's (Mason-Apps, 2002).

The best drilling results came from the Granodiorite Zone, composed of pre- to syn-tectonic plutonic rocks that are approximately $2.72 \mathrm{Ga}$ (Sanborn-Barrie et al., 2004). The mineralization is defined by fracture-filling auriferous quartz veins within the granodiorite. The Granodiorite Zone is oriented to the NE at approximately $40^{\circ}$ along strike of the East Bay trend adjacent to Abino Point with a dip of $70^{\circ} \mathrm{W}$. There are two definable vein types that occur; the $1 \mathrm{D}$ quartz stringers oriented parallel to strike and the 2D quartz stringers that are oriented 
approximately $020^{\circ}$ with an easterly dip (Mason-Apps, 2002).

\subsection{4 - Chevron Zone}

The Chevron zone is located at the southernmost point of East Bay, lying beneath a large marshland, and occurs within the Abino claim block. This area underwent similar preliminary exploration as the rest of the Abino property (Fumerton et al., 1990). Due to a lack of outcrop and the discoveries further north at Abino Point, this area remained relatively untouched for decades.

In 1989, Chevron Minerals Canada Ltd acquired a 50\% option on Goldquest Exploration's properties and began testing the East Bay structure with 7 surface drill holes. An extensive drilling program started in 1990 (Fumerton et al., 1990) to better define the East Bay Deformation Zone (EBDZ) and the Chevron Zone. Chevron Minerals Ltd dropped their option in 1991 and it returned to Goldquest. Goldcorp Inc. (owner of Goldquest) began a follow-up drilling project in 1993 on the Chevron Zone and determined that sections were very discontinuous and reserve determination would require tighter spacing of drill holes (Mason-Apps, 2002). In 1994 drilling continued extending the strike-length of the mineralization with an estimated 65,000 tons of ore at a grade of 9.0 gpt. Drilling continued between 1997 and 2001, but the mineralization was still considered too discontinuous and low grade (Sannes \& Dehn, 2000).

\subsection{5 - McFinley/Duchesne}

The McFinley mine has a long history of exploration and attempted mining, but never produced gold. The property was first staked in 1922, initially tracking a 
silver occurrence on McFinley peninsula. Trenching, sampling and shallow drilling by McCallum Red Lake Mines Ltd., identified extensive but erratic gold mineralization in cherty sediments. In 1941 the Wartime Minerals Evaluation program drilled several gold occurrences (Hogg, 2002). In 1944-46, McFinley Red Lake Gold Mines Ltd. carried out a ground magnetic survey and extensive surface drilling. In 1955, Little Long Lac Gold Mines sank a 428-foot shaft on McFinley peninsula with 1,358 feet of exploration drifting, but work terminated in 1956. In 1974-75 Sabina Industries proceeded with drilling and ground magnetic and electromagnetic surveys across the property. From 1980 to 1987 the property was under the ownership of several different companies (Thomas, 2009). From 1987 to 1989 a 150-ton per day mill and tailings area were constructed with underground development and drilling. Due to logistical problems the project ceased in 1989. In 2002 Rubicon Minerals, who began an exploration campaign involving drilling and airborne geophysics, optioned the property. Rubicon continued their exploration drilling programs for several years, focusing on the Phoenix Gold Project (Fig. 1.3), until they intersected the F2 zone in 2008 (Thomas, 2009). Rubicon has continued its drilling programs and the shaft has been dewatered and deepened to 338 metres allowing for the development of the 305-metre level. They are currently undergoing economic analyses and feasibility studies on the F2 zone. Rubicon is also in the process of completing all permits, including a mine closure plan and they are also preparing a tailings management facility (Thomas, 2009). Rubicon intends to begin production from the F2 zone with a fully operational mine site by 2014 (Russell, Pers. Comm., 2011). In early 2011, Rubicon extracted two 1,000 t bulk samples representing two underground areas on the 305 level. Further 
information on the history of the McFinley property can be found in Hogg (2002), Thomas (2009), and Smith et al. (2011).

(Removed due to Copyright)

Figure 1.3 - Map of the Eastern Red Lake Belt with mining properties indicated with yellow stars (Modified after Thomas, 2009) 


\section{4 - Thesis Objectives}

The Red Lake district is one of the most significant gold producers within the Superior Province, having produced over 27 million ounces (Lichtblau et al., 2012). The majority of the gold has been produced by the Red Lake Gold Mines (RLGM) operated by Goldcorp Inc. from localities along the "Mine Trend". In comparison, gold mineralization associated with the EBT is relatively poorly understood, as the structures, regional deformation zones, timing, depositional controls, and origin of gold mineralization have not been investigated or explored to the same extent as the RLGM.

The objectives of this study are: (1) identify the structures that host gold mineralization in the EBT and compare the structural styles with the other wellstudied structures in the Red Lake deposits along the mine-trend (e.g., Red Lake, Campbell Mine), (2) identify key differences between barren and auriferous veins, including alteration minerals, and (3) compare the ages and fluid chemistry of the mineralized zones along the East Bay trend with the deposits along the mine-trend. These data will characterize the time and geochemistry of auriferous and barren fluids, place these fluid events within the tectonic evolution of the Red Lake district, and develop a genetic model for these deposits. A detailed genetic model would assist in the targeting of areas that could host gold mineralization. 


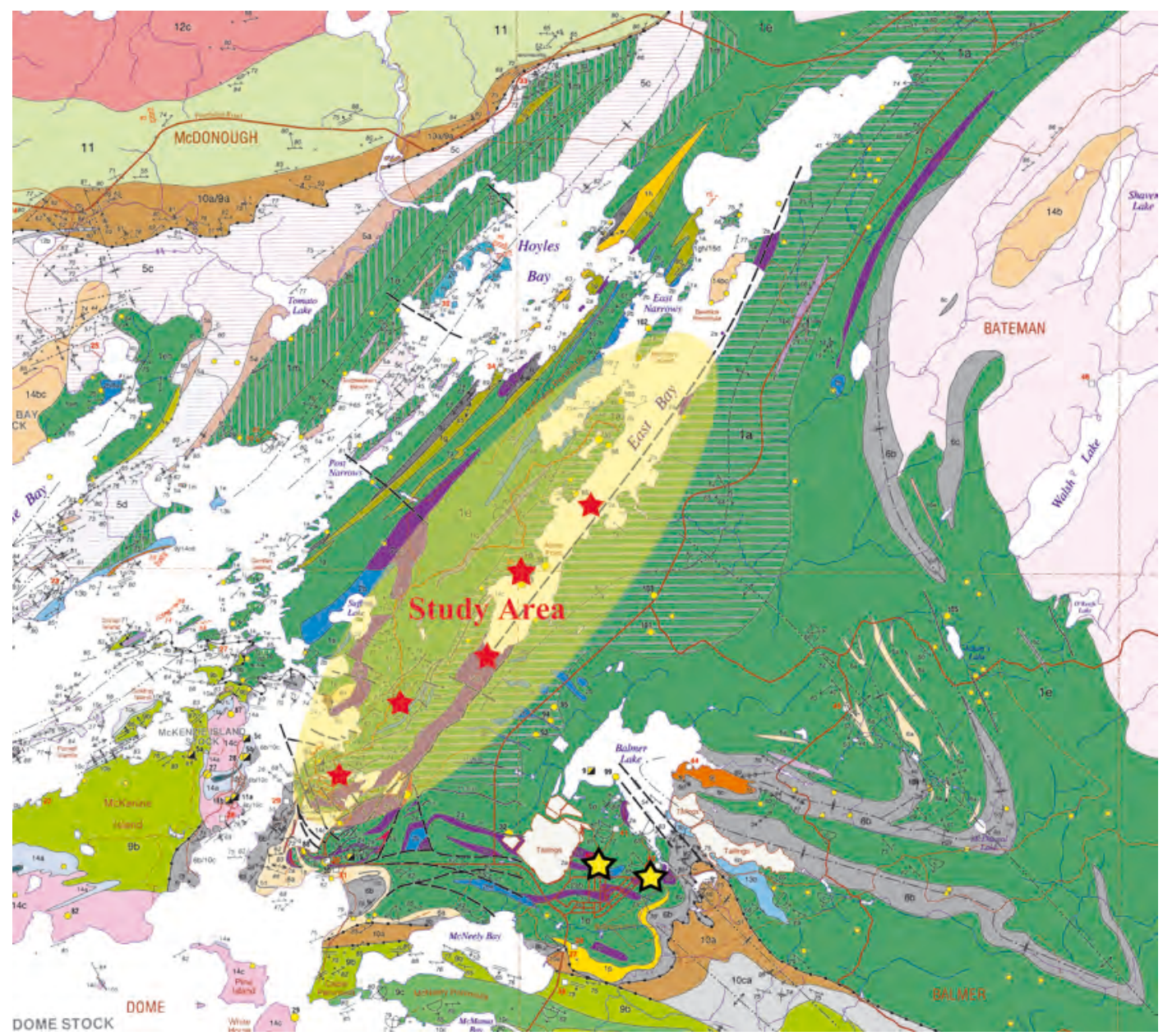

Figure 1.4 - Map of the eastern Red Lake Greenstone belt with the study area shown in red with the Red Lake Gold Mines indicated with small yellow stars (modified after Sanborn-Barrie et al., 2004) 


\section{Chapter 2 - GeologY}

\section{1 - Regional Geology}

The RLGB is located in the western portion of the Uchi Subprovince, Superior Province (Fig. 2.1), northwestern Ontario (Fig. 2.1; Dubé et al., 2004; Tarconai, 2000). The RLGB has an east-trend and covers an area of $\sim 1500$ square kilometers composed of Archean igneous and sedimentary rocks surrounded by granitoid plutons (Parker, 2000a). These rock units represent a magmatic and depositional history of nearly 300 million years beginning with the ca. 3.00 Ga Balmer volcanics and ending with the $\sim 2.70$ Ga post-tectonic plutonic rocks that form the English River assemblage (Sanborn-Barrie, 2004). The supracrustal rocks of the greenstone belt are divided into two distinct sequences; the Mesoarchean and the Neoarchean assemblages, when combined include 9 well-defined assemblages (Sanborn-Barrie, 2004). These assemblages are further summarized in table 2.1 and can be observed geographically at the regional scale in figure 2.2. Although the entire belt has undergone metamorphism, the prefix "meta" will not be used before the name of different lithologies, for simplicity.

\subsection{1 - Mesoarchean Rocks}

Mesoarchean assemblages dominate the belt and consist of: (I) Balmer assemblage ( $>2.99 \mathrm{Ga})$ mafic-ultramafic volcanic rocks; (II) Ball assemblage $(\sim 2.92$ to $\sim 2.94 \mathrm{Ga}$ ) flows and pyroclastic rocks of intermediate to felsic calc-alkaline composition that are only seen in the western extremity of the belt and have been significantly pinched out; (III) Slate Bay Assemblage ( $<2.92 \mathrm{Ga})$ clastic-dominated 
sequences that disconformably overlies the Balmer Assemblage, as much of the Ball Assemblage has been removed or pinched out; (IV) Bruce Channel Assemblage $(\sim 2.89 \mathrm{Ga})$ of intermediate calc-alkaline pyroclastic rocks overlain by clastic sedimentary rocks and banded iron-formation and; (V) Trout Bay Assemblage ( 2.85 Ga) of volcano-sedimentary rocks with very little exposure (Fig. 2.2) (Pirie, 1981; Sanborn-Barrie et al., 2001; Dubé et al., 2004).

\subsection{2 - Neoarchean Rocks}

A regional angular unconformity separates the basal sequences of the Mesoarchean rocks from the upper Neoarchean volcanic rocks. The less equally represented Neoarchean rocks, commence with: (I) Confederation assemblage $(\sim 2.74$ to $\sim 2.75 \mathrm{Ga})$ of calc-alkaline and tholeiitic volcanics and volcaniclastic rocks that occur as the basal assemblage (adjacent to unconformity); (II) Huston assemblage $(<2.89$ to $>2.74 \mathrm{Ga}$ ) polymictic conglomerates and finer clastic sedimentary rocks, and; (III) Graves assemblage ( $\sim 2.73 \mathrm{Ga})$ of calc-alkaline rocks (Fig. 2.2) (Sanborn-Barrie et al., 2001; Sanborn-Barrie et al., 2004). 


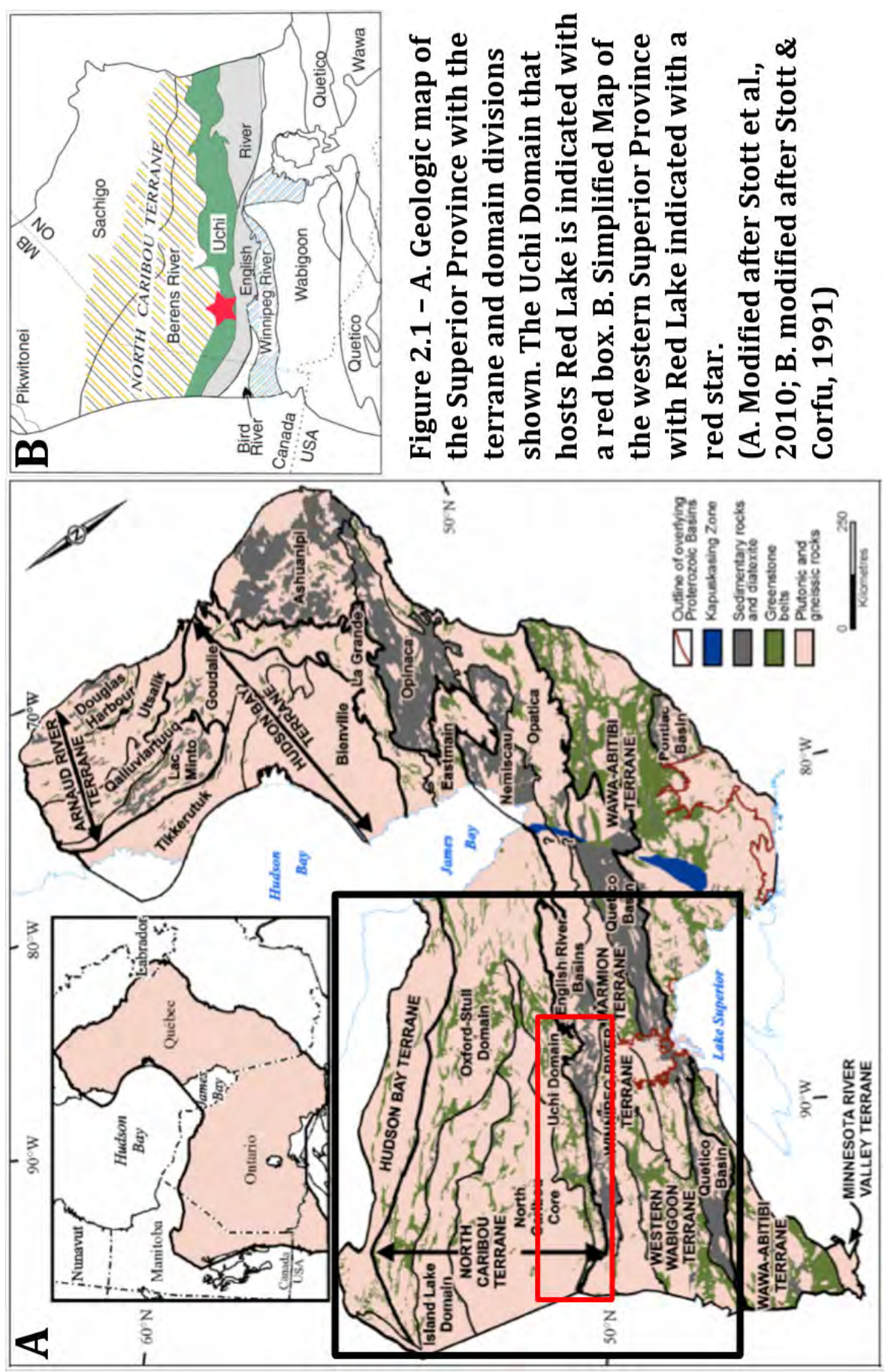


Table 2.1 - Summary of the geological units in the Red Lake greenstone belt. U-Pb zircon dating by Corfu and Wallace (1986) and Corfu and Andrews (1987) bracket the age of the individual assemblages. Irregular boundary between the Confederation and Huston Assemblages indicates an angular unconformity. Descriptions are from Sanborn-Barrie et al. (2001) and Parker (2000a) (Modified after Parker, 2000a)

\begin{tabular}{|c|c|c|}
\hline \multicolumn{3}{|c|}{ Main Geologic Units } \\
\hline Assemblage & Age & Description \\
\hline \multicolumn{3}{|l|}{ Mesoarchean } \\
\hline (I) Balmer & $>2.99 \mathrm{Ga}$ & $\begin{array}{l}\text { Submarine tholeiitic basaltic and ultramafic rocks, with minor felsic } \\
\text { volcanic, iron formations and fine-grained clastic rocks. The Balmer } \\
\text { basalts have high Ti content up to } 2 \mathrm{wt} \% \text {. }\end{array}$ \\
\hline (II) Ball & $\begin{array}{l}\sim 2.94-2.92 \\
\mathrm{Ga}\end{array}$ & $\begin{array}{l}\text { Basalt, andesite, dacite, rhyolite, minor komatiite flows, } \\
\text { conglomerate, quartzite and } \mathrm{m} \text { arbles. The basalts are low in titanium } \\
(<0.5 \mathrm{wt} \%) \text {. Restricted to the northwest portion of Red Lake district, } \\
\text { and in contact with the Balmer Assemblage. }\end{array}$ \\
\hline (III) Slate Bay & $\begin{array}{l}\sim 2.85-2.90 \\
\mathrm{Ga}\end{array}$ & $\begin{array}{l}\text { Clastic sequence that includes feldspathic wacke interbedded with } \\
\text { lithic wacke, argillite, and lenses of conglomerate. This assemblage } \\
\text { lies unconformably over the Balmer assemblage. }\end{array}$ \\
\hline $\begin{array}{l}\text { (IV) } \\
\text { Bruce Channel }\end{array}$ & $\sim 2.89 \mathrm{Ga}$ & $\begin{array}{l}\text { Volcaniclastic rocks }(<500 \mathrm{~m} \text { thick) overlain locally by chert-pebble } \\
\text { conglomerate, crossbedded wacke, siltstone, and quartz-magnetite } \\
\text { iron formation. }\end{array}$ \\
\hline (V) Trout Bay & $\sim 2.85 \mathrm{Ga}$ & $\begin{array}{l}\text { Volcano-sedimentary sequence dominated by basalts overlain by } \\
\text { clastic rocks, intermediate tuff, and chert-magnetite iron formations. } \\
\text { Gabbros and lesser ultramafics intrude these units and are prospective } \\
\text { for nickel, copper and platinum group elements. }\end{array}$ \\
\hline \multicolumn{3}{|l|}{ Neoarchean } \\
\hline $\begin{array}{l}\text { (I) } \\
\text { Confederation }\end{array}$ & $\begin{array}{l}\sim 2.75-2.74 \\
\mathrm{Ga}\end{array}$ & $\begin{array}{l}\text { Three temporally and spatially distinct magmatic units: McNeely calc- } \\
\text { alkaline sequence in central Red Lake district, Heyson tholeiitic } \\
\text { sequence in south-eastern Red Lake district and the Graves calc- } \\
\text { alkaline sequence to the north. }\end{array}$ \\
\hline (II) Huston & Ga & $\begin{array}{l}\text { Polymictic conglomerate with a few beds of argillite and turbiditic } \\
\text { wacke that marks the angular unconformity between the Mesoarchean } \\
\text { and the Neoarchean }\end{array}$ \\
\hline (III) Graves & $\sim 2.73 \mathrm{Ga}$ & $\begin{array}{l}\text { Calc-alkaline rocks, primarily andesite to dacite pyroclastic rocks and } \\
\text { synvolcanic diorite and tonalite. Represents shallow water to subaeriel } \\
\text { arc complex. }\end{array}$ \\
\hline
\end{tabular}

\subsection{3 - Deformation History}

The RLGB preserves evidence for several deformational episodes (Fig. 2.3)

that are synchronous with extensive hydrothermal activity and gold mineralization 
(Dubé et al., 2004). Large-scale folds and fault systems represent deformation corridors within the eastern RLGB. The main penetrative fabrics are associated with ductile deformation during $\mathrm{D}_{2}$ (Crick et al., 2006). The earliest deformation event $\left(D_{0}\right)$ in the RLGB is associated with recumbent folds and overturning of the Balmer assemblage prior to deposition at 2.75 Ga (Sanborn-Barrie et al, 2004), the age of the unconformably overlying Confederation assemblage tholeiitic sequences.

Neoarchean volcanism $(\sim 2.75 \mathrm{Ga})$ was followed by at least two generations of ductile deformation ( $\mathrm{D}_{1} \& \mathrm{D}_{2}$ ) (Fig. 2.3) (Sanborn-Barrie et al., 2001).

The first major ductile deformation $\left(D_{1}\right)$ involved the development of $F_{1}$ folds and generated a northeasterly plunging fold axis and associated fabrics $\left(\mathrm{S}_{1} \& \mathrm{~L}_{1}\right)$ (Crick et al., 2006). The $F_{1}$ folds are best observed in the clastic-dominated assemblages (Bruce Channel, Slate Bay, and Huston) with $S_{1}$ best developed in volcanic rocks, such as the Balmer Assemblage (Sanborn-Barrie et al., 2001). Overall $\mathrm{S}_{1}$ is weakly developed and trends $\sim 020-040^{\circ}$ and dips between $\sim 50-85^{\circ}$ to the northwest in the eastern portion of the belt (EB area). The belt-wide presence of $D_{1}$ structures suggests that $\mathrm{D}_{1}$ involved regional-scale, east-west shortening (SanbornBarrie et al., 2001). The $D_{1}$ event is constrained between the $F_{1}$ and $F_{2}$ folds that affect tuffs in the McNeely sequence of central Red lake $(\sim 2.74 \mathrm{Ga})$ and the lack of $\mathrm{D}_{1}$ structures recorded in the $\sim 2.73 \mathrm{Ga}$ Graves sequence, providing a minimum age for the deformational event (Sanborn-Barrie et al., 2001). O’Dea (1999) noted overprinting evidence and concluded that the northeast-trending East Bay domain was mainly developed during $\mathrm{D}_{1}$ deformation and was later overprinted by the southeast-trending $\mathrm{D}_{2}$ fabric. 
Northeast-southwest directed compression during $\mathrm{D}_{2}$ resulted in $\mathrm{F}_{2}$ folds and a $S_{2}$ penetrative fabric across the terrane that is strongly expressed in the Balmer assemblage (Crick et al., 2006). A series of south dipping, southeast to east-west striking shear zones associated with $\mathrm{D}_{2}$ fabric transect the greenstone belt and represent the main penetrative fabric (Fig. 2.3). The major gold deposits in the Red Lake Camp are located along moderately developed ductile $S_{2}$ fabrics with an orientation of $120-135^{\circ}$ and dipping $60-85^{\circ}$ to the southwest (known as "mine trend"; Crick et al., 2006). The ductile $S_{2}$ fabrics form a east-southeast striking $\left(\sim 110-120^{\circ}\right)$ corridor of variably strained rock that extends from Cochenour through Balmertown. On the west side of Red Lake, $S_{2}$ trends to the northeast (Fig. 2.3; Fig. 2.4) (Sanborn-Barrie et al., 2001). The $\mathrm{D}_{2}$ deformational event is constrained between the deformed $\sim 2.74$ Ga Confederation volcanics, providing a maximum age, and the limited deformation of the $\sim 2.72$ Ga intra-belt plutons related to $D_{2}$, such as the Dome Stock that offers a minimum age (Sanborn-Barrie et al., 2001).

Sanborne-Barrie et al. (2001) interpreted the northeast-trending fabric on the west side of Red Lake and the southeast-trending $\mathrm{D}_{2}$ fabrics on the east side formed coevally, but were rotated into different orientations in the rocks that surround the intruding syn-tectonic McKenzie stock and Dome stock ( $2.72 \mathrm{Ga})$, which remain undeformed. This variation of fabrics indicates a possible synchronous development with the $\sim 2.72$ Ga Dome stock and McKenzie stock (Fig. 2.3) (Sanborn-Barrie et al, 2001). The time frame for $D_{2}$ deformation is constrained by weak $\mathrm{S}_{3}$ fabrics in the $\sim 2.72$ Ga Dome stock. These stocks contain xenoliths of the 
adjacent supracrustal rocks that posses a strong $S_{2}$ fabric, while the stock itself possesses a weak foliation that is coplanar to the regional $S_{2}$ fabric. This would indicate that the main cleavage-forming stage of $\mathrm{D}_{2}$ predated the Dome stock intrusion of $\sim 2.72 \mathrm{Ga}$ (Sanborn-Barrie et al, 2001). The penetrative $\mathrm{D}_{2}$ fabric throughout the RLGB is interpreted to result from the collision during the Uchian phase of the Kenoran orogeny ( $\sim 2.72$ to $\sim 2.71 \mathrm{Ga}$.), which involves collision along the continental margin of the North Caribou terrane (Fig. 2.1) with the $\sim 3.40 \mathrm{Ga}$ Winnipeg River terrane to the south (Chi et al., 2009; Dubé et al., 2004, SanbornBarrie et al, 2001). Deformation and metamorphic events are summarized in Table 2.3. The pervasive foliation fabrics produced by the regional deformational events have developed in a series of deformation corridors and can be identified with airbourne magnetics (Fig. 2.4; Sanborn-Barrie et al., 2001).

These deformational events can be related to changes in plate dynamics, such as shallowing of the northward subduction angle resulting in upper plate compression and a shift in location of magmatic activity further to the north (Sanborn-Barrie et al, 2001). This interpretation of the deformation history has become contested in recent years and is currently being reevaluated using all available data (Epp, Pers. Comm.). 


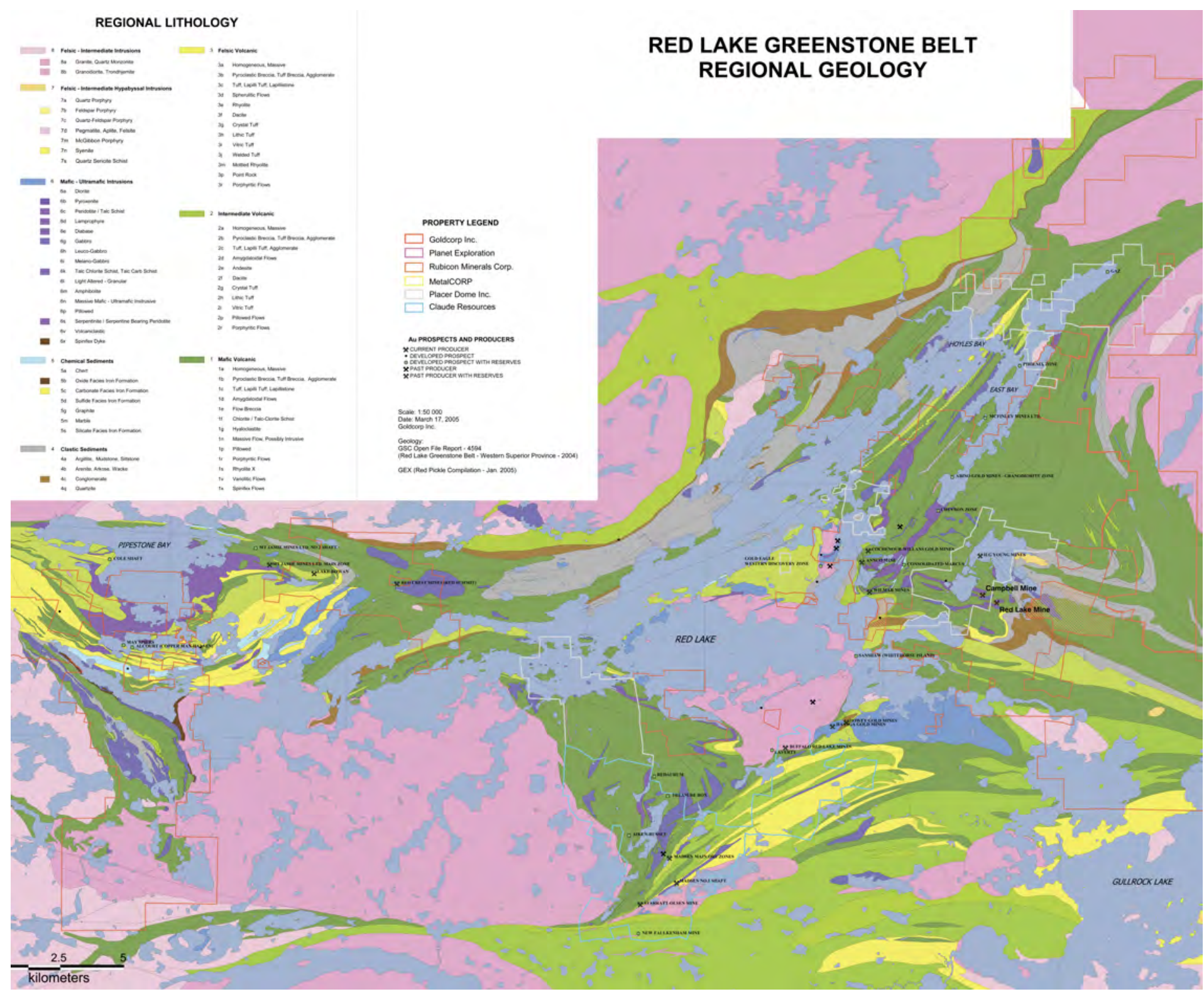

Figure 2.2 - Red Lake Greenstone Belt Simplified Regional Geology (modified after Goldcorp's MapInfo Layers Data) 

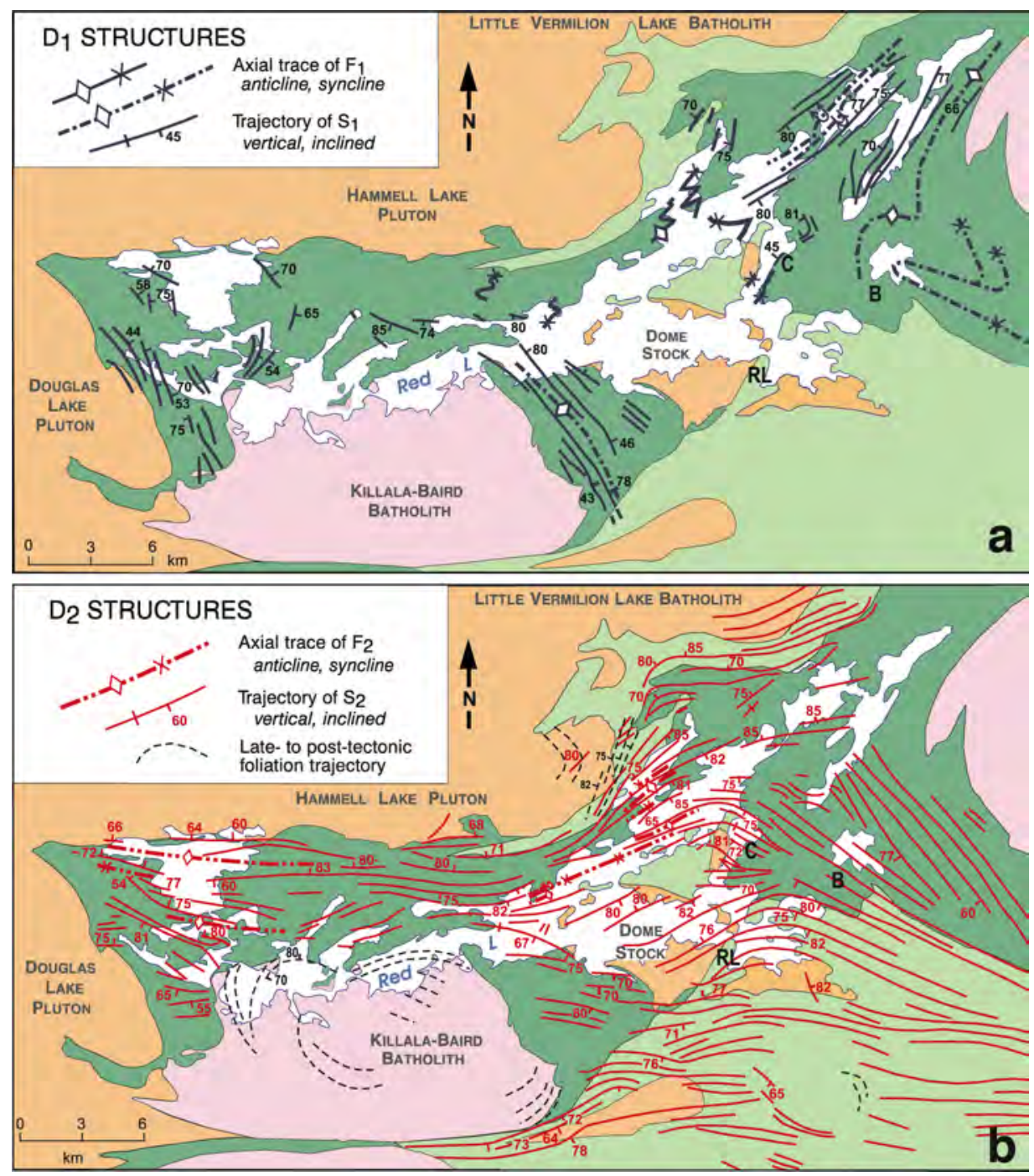

Figure 2.3 - Generalized map of the Red Lake greenstone belt showing (a) the trend of $\mathrm{D}_{1}$ structures and (b) $\mathrm{D}_{2}$ structures. $\mathrm{RL}=$ Red Lake, $\mathrm{B}=$ Balmertown and $\mathrm{C}=$ Cochenour (Sanborn-Barrie et al., 2004). 


\section{Red Lake Greenstone Belt - Deformation Zones}

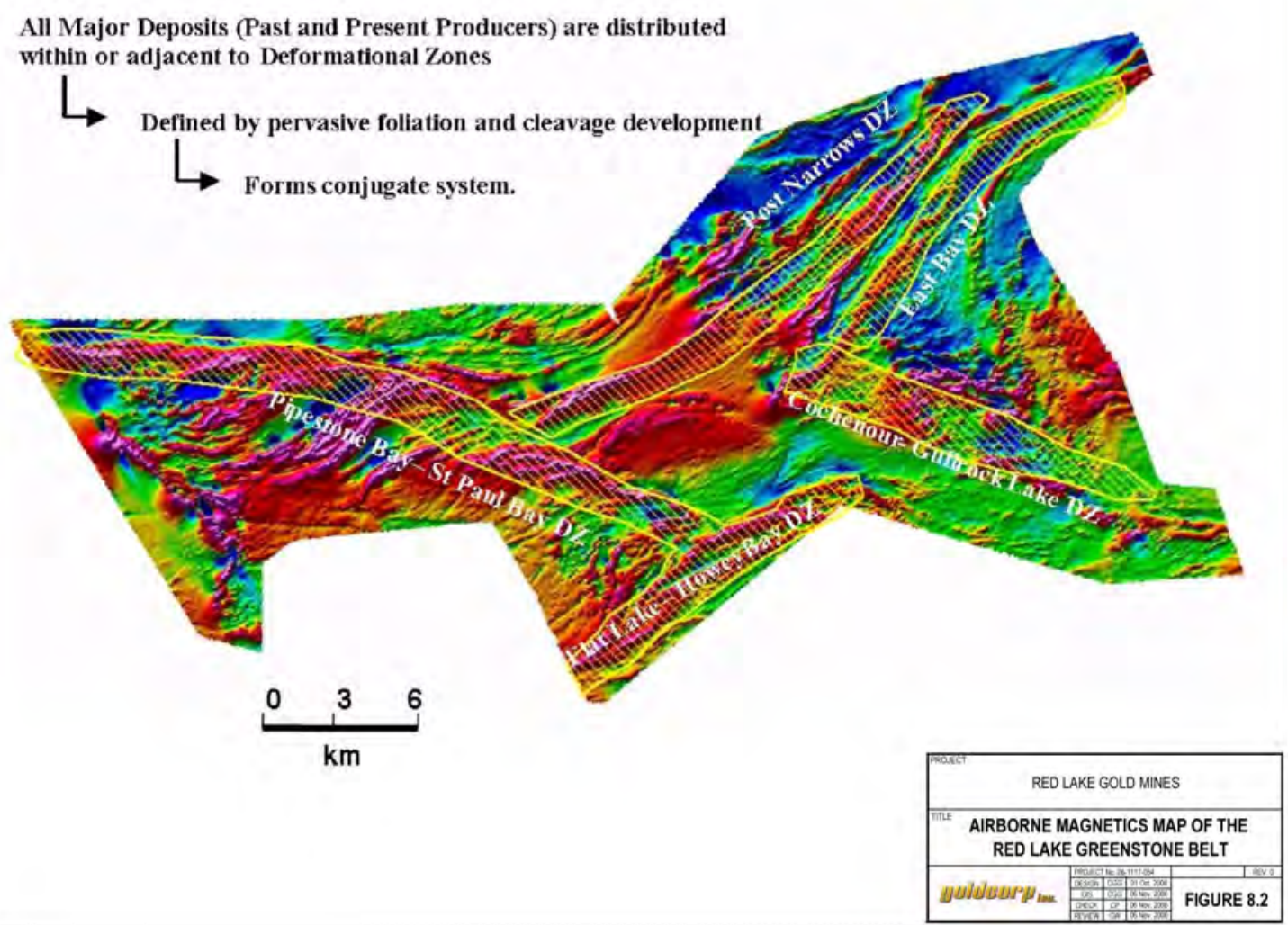

Figure 2.4 - Airborne Magnetics Map of the Red Lake Greenstone Belt demonstrating the deformation zones highlighted in yellow (modified after Crick et al., 2006)

\subsection{4 - Magmatic History}

The supracrustal assemblages were intruded by several plutonic bodies, during 3 magmatic episodes relative to $\mathrm{D}_{2}$ deformation: (1) pre-orogenic $(>2730$ Ma) (2) early syn-orogenic ( $\sim 2.70-2.72 \mathrm{Ga})$ and (3) late syn-orogenic $(\sim 2.70-2.69$ Ga) (Thompson, 2003).

The pre-orogenic plutonic rocks are predominantly mafic in composition and typically intrude the various Mesoarchean volcanic assemblages. This episode 
includes diorites and ultramafics that typically intrude the Balmer volcanics throughout the belt (Sanborn-Barrie et al., 2004).

Syn-orogenic intrusives include the Dome and McKenzie stocks, which intrude the core of the RLGB disturbing the stratigraphy and structure in these rocks (Sanborn-Barrie et al., 2001). These rocks intruded between $\sim 2.72-2.70 \mathrm{Ga}$ and are intermediate to felsic in composition, forming stocks and batholiths within the RLGB (Sanborn-Barrie et al., 2004).

The late syn-orogenic plutons are principally granitic rocks (tonalite, monzogranite and, granodiorite) that surround the RLGB. Many of these units are voluminous forming large stocks and batholiths that once they emplaced produced the arrangement of rocks that are present (Sanborn-Barrie et al., 2004).

\subsection{5 - Thermal History}

The timing and number of metamorphic events in the RLGB has been debated in the past, because later metamorphic events overprint the earlier events $\left(M_{0}\right)$, which complicate the identification of metamorphic events. The regional metamorphic grade of the belt prior to batholithic emplacement was greenschist facies $\left(M_{1}\right)$, and is often associated with $D_{1}$ (Thompson, 2003). Narrow contact metamorphic aureoles occur adjacent to syn-orogenic stocks (group 2 intrusions - early syn-orogenic) producing $M_{2}$ metamorphic assemblages (mainly by metasomatism of surrounding mafic rocks). Towards the margins of the belt the metamorphic grade increases to amphibolite facies $\left(\mathrm{M}_{3}\right)$, and is attributed to the thermal effects of group 3 (post-orogenic) intrusions that emplaced along the 
margins of the belt. The rocks in the central region of the belt were unaffected by the thermal aureoles of intrusions and remain at greenschist facies, due to the lack of group 3 intrusions (Sanborn-Barrie et al., 2001; Thompson, 2003).

Although the intrusions cause an elevated metamorphic grade along the margins of the belt, they cannot account for the metamorphic grade of the entire region (Fig. 2.5; Thompson, 2003). Thompson (2003) determined that the granitoids of the area are not of the right age to be the source of the heat for the regional metamorphism. Regional metamorphism peaked during the main orogenic phase and is associated with ductile deformation due to crustal shortening and thickening (Chi et al., 2009), which caused increased metamorphism during $\mathrm{D}_{2}$. Tempratures were elevated along the margins of the belt from granitic intrusions causing an overlap between metamorphic events (Thompson, 2003).

Most of the major gold deposits in the Red Lake district are hosted in the $\sim 2.99$ Ga Balmer Assemblage, that is adjacent to the regional unconformity that the Balmer Assemblage shares with the $2.75-2.74$ Ga Confederation Assemblage (Dubé et al., 2004, Sanborn-Barrie, 2001). The fact that these gold deposits are either hosted in amphibolite facies rocks (Madsen Mine) or primarily in rocks straddling the transition between the amphibolite-greenschist isograd (Red Lake deposit) suggests that major deposition of gold is closely related to peak metamorphism throughout the RLGB (Dubé et al., 2004, Tarnocai, 2000). 
Table 2.2 - Timing of deformation and metamorphism in eastern Red Lake (Modified after tables from Menard et al., 1999; Tarnocai, 2000)

\begin{tabular}{|c|c|c|}
\hline Deformation & Metamorphism/Alteration & Age \\
\hline \multirow{5}{*}{$\begin{array}{l}\mathbf{D}_{1}-\mathrm{NE} \text { trending isoclinal folding } \\
\text { across the eastern part of the belt } \\
\text { with NE trending deformation } \\
\text { zones. } \\
\text { - Early granitic intrusions. }\end{array}$} & & $c^{\prime}$ \\
\hline & $\begin{array}{l}\mathbf{M}_{1}-\text { Possible greenschist facies, } \\
\text { may be } D_{2} \text { in timing? }\end{array}$ & \multirow[t]{4}{*}{ Pre $-2720 \pm 2 \mathrm{Ma}$} \\
\hline & $\begin{array}{l}\text { - Widespread early carbonate } \\
\text { alteration. }\end{array}$ & \\
\hline & $\begin{array}{l}\text { - Variable biotite \& chlorite } \\
\text { alteration (perhaps } \mathrm{M}_{2} \text { ?) }\end{array}$ & \\
\hline & - Early granitic intrusions & \\
\hline \multirow{4}{*}{$\begin{array}{l}\mathbf{D}_{2}-\mathrm{NW} \text { trending, moderately } \\
\text { SW plunging vertical folds } \\
\text { proximal to Trout Lake batholith. } \\
\text { - Variable NW to WNW trending, } \\
\text { SW dipping foliations. } \\
\text { - NW deformation zones on } \\
\text { attenuated } \mathrm{F}_{2} \text { limbs }\end{array}$} & $\begin{array}{l}\mathbf{M}_{2}-\text { Peak Metamorphism along } \\
\text { edges of the belt (Amphibolite } \\
\text { facies) }\end{array}$ & \multirow[t]{4}{*}{$2718 \pm 1$ to $2720 \pm 2 \mathrm{Ma}$} \\
\hline & $\begin{array}{l}\text { - Narrow contact metamorphic } \\
\text { aureoles adjacent to McKenzie \& } \\
\text { Dome stocks }\end{array}$ & \\
\hline & $\begin{array}{l}-\mathrm{K}, \mathrm{SiO} 2 \text {, and sulphide mobility } \\
\text { in the belt and gold mobility at } \\
\text { RLGM }\end{array}$ & \\
\hline & $\begin{array}{l}\text { - Granitic Batholiths \& diorite } \\
\text { stocks }\end{array}$ & \\
\hline \multirow{2}{*}{$\begin{array}{l}\mathbf{D}_{3} \text { - Sinistral strike-slip shear } \\
\text { along the East Bay and Post } \\
\text { Narrows Deformation Zones } \\
\text { (reactivation?). } \\
\text { - Shear zone hosted asymmetric } \\
\text { folds with steep dipping axial } \\
\text { planes }\end{array}$} & $\begin{array}{l}\mathbf{M}_{3} \text { - Wide }(\mathrm{km} \text {-scale) } \\
\text { amphibolite facies contact } \\
\text { metamorphic aureole, associated } \\
\text { with late syn- to post-orogenic } \\
\text { intrusions }\end{array}$ & \multirow[t]{2}{*}{$\begin{array}{l}\text { Syn- to post- } 2699 \pm 1 \mathrm{Ma} \text {. } \\
\text { East Bay deformation zone cuts } \\
\text { the Dome stock and } \mathrm{F}_{2} \text { fold axes. }\end{array}$} \\
\hline & $\begin{array}{l}\text { - Retrograde greenschist facies } \\
\text { metamorphism }\end{array}$ & \\
\hline \multirow[t]{2}{*}{ - Mylonitic Deformation } & $\begin{array}{l}\text { - Alteration to chlorite }+ \text { epidote }+ \\
\text { carbonate }\end{array}$ & \\
\hline & $\begin{array}{l}\text { - Small gold deposits in diorite } \\
\text { stocks }\end{array}$ & \\
\hline $\mathbf{D}_{4}$-Final Granitic Batholiths & $\mathbf{M}_{\mathbf{4}}$ - Retrograde metamorphism & 2680 to $2650 \mathrm{Ma}$ ? \\
\hline \multicolumn{3}{|l|}{ - Brittle deformation } \\
\hline $\begin{array}{l}\text { - Minor thin carbonate veins } \\
\text { cross-cut the region }\end{array}$ & & \\
\hline
\end{tabular}

* = Age data by U-Pb zircon, from Corfu and Wallace (1986), Corfu and Andrews (1987), and SanbornBarrie et al. (2004) 


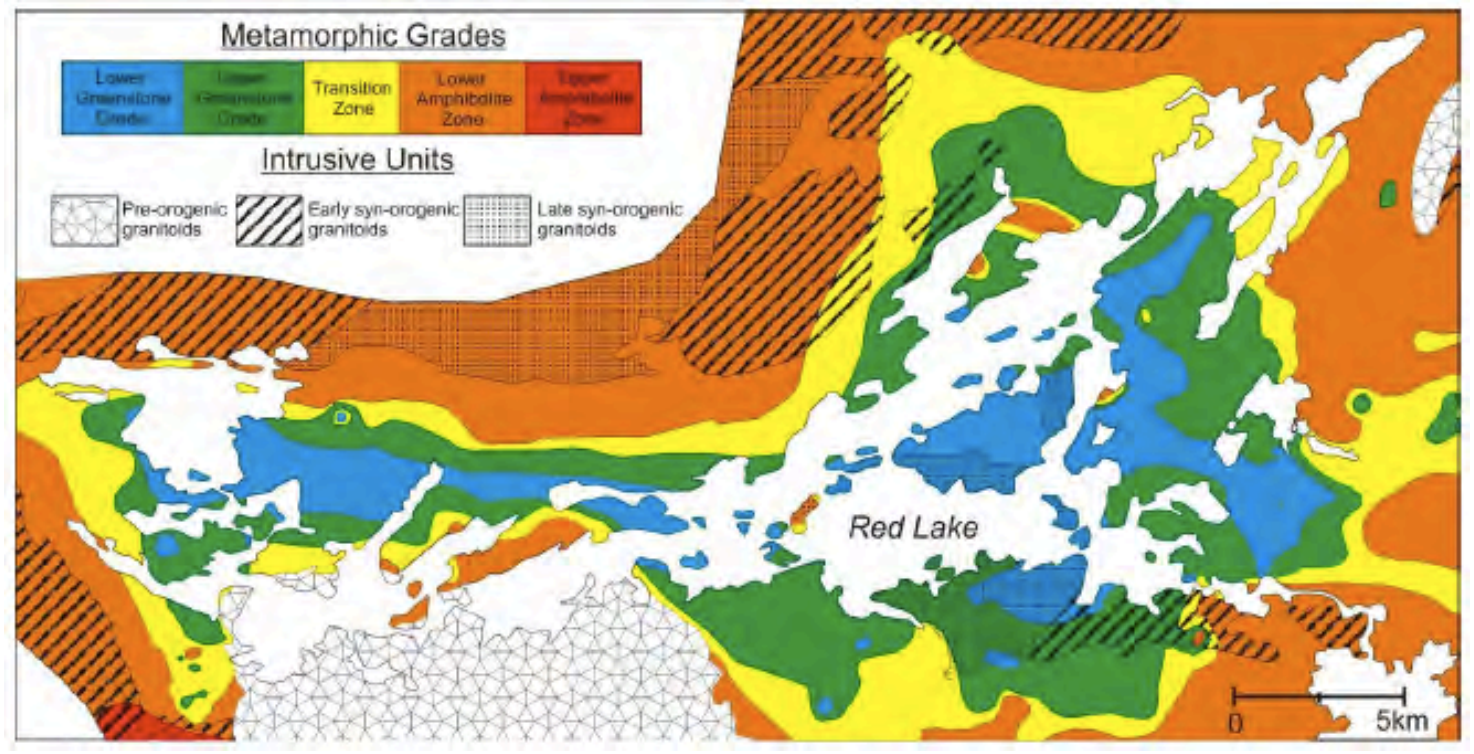

Figure 2.5 - General map of regional metamorphic grade and intrusive units of the Red Lake Belt (modified after Thompson, 2003)

\section{2 - Geology of the East Bay Area}

The rocks of the East Bay area are dominated by northeast-trending, westdipping units of the Balmer sequence; tholeiitic to komatiitic volcanics with intercalated sedimentary units and late mafic to felsic intrusions (Mason-Apps, 2002). This area lies along two significant regional structures, including the northeast-trending East Bay deformation Zone (EBDZ; $\mathrm{D}_{1}$ ) and the northwesttrending Cochenour-Gullrock Deformation Zone (CGDZ; D2; Mason-Apps, 2002).

Rocks found throughout East Bay are pillowed and locally varioliticspherulitic flows of the Balmer assemblage. These fine-grained rocks contain actinolite as well as biotite and possess a generally uniform texture (Goldcorp Inc., 2006). Komatiitic flows also occur and are identified by spinifex textures in otherwise fine green, featureless rocks.

The East Bay Serpentinite is predominantly composed of serpentinite, 
serpentinized peridotites and talc schists (Sanborn-Barrie et al., 2004). The ultramafic rocks are altered and deformed within discrete corridors sub-parallel to the dominant EBDZ and emplaced after the $~ 2.99$ Ga Balmer volcanics, but prior to the $\sim 2.94$ Ga Ball assemblage (Sanborn-Barrie et al., 2004).

Along East Bay a variety of granitic intrusions occur, including the Beatrice Tonalite, Abino Granodiorite ( 2.72 Ga; Corfu \& Andrews, 1987)) and the Campbell Gabbro/Diorites. These intrusions range in age from pre-tectonic (Campbell intrusives) to post-tectonic (Beatrice, Abino intrusives), indicating that the EB area was an active pathway for magmatic fluids throughout the tectonic history of the RLGB (Sanborn-Barrie et al., 2004).

The Balmer assemblage is intruded by numerous generations of dykes, such as the older generation of feldspar \pm quartz porphyry dykes near Abino $(2714 \pm 4$ Ma) that appear as quartz-phyric rocks that are typically fine-grained (Goldcorp Inc., 2006). These dykes are generally well preserved, unless they are in close proximity to the EBDZ.

Lamprophyre dykes $(\sim 2702 \pm 2 \mathrm{Ma})$ intrude all units along the EBT; they are a fine-grained, massive and have chilled margins. These dykes often intrude sub-parallel to the $S_{1}$ fabric and are no more than a few metres wide (Goldcorp Inc., 2006). Further description of these units is presented in sections 2.2.1 through 2.2.3. 


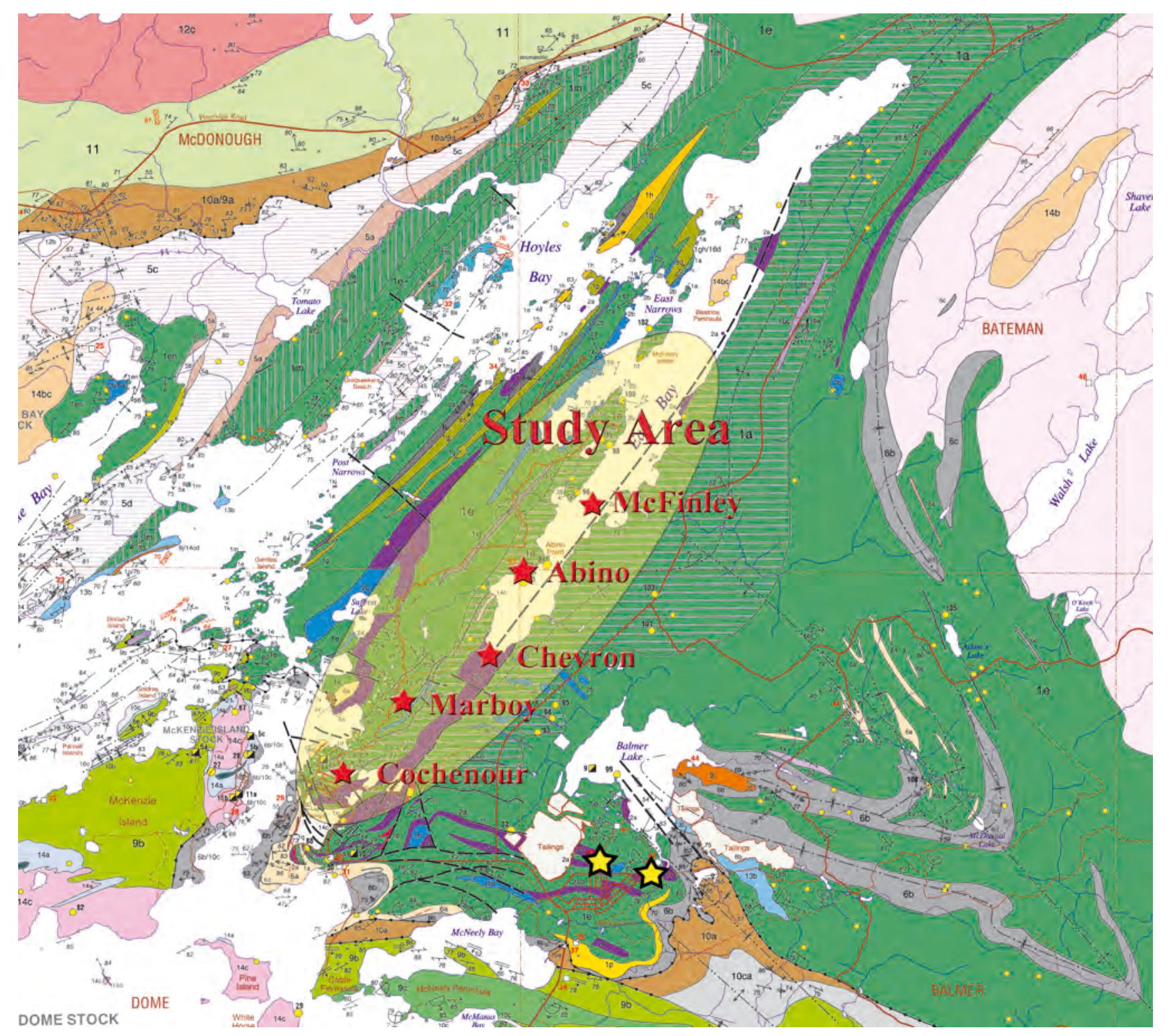

Figure 2.6 - Geology of the East Bay and Red Lake Gold Mines areas with the study location indicated in yellow (modified after Sanborn-Barrie et al., 2004). 
LEGEND

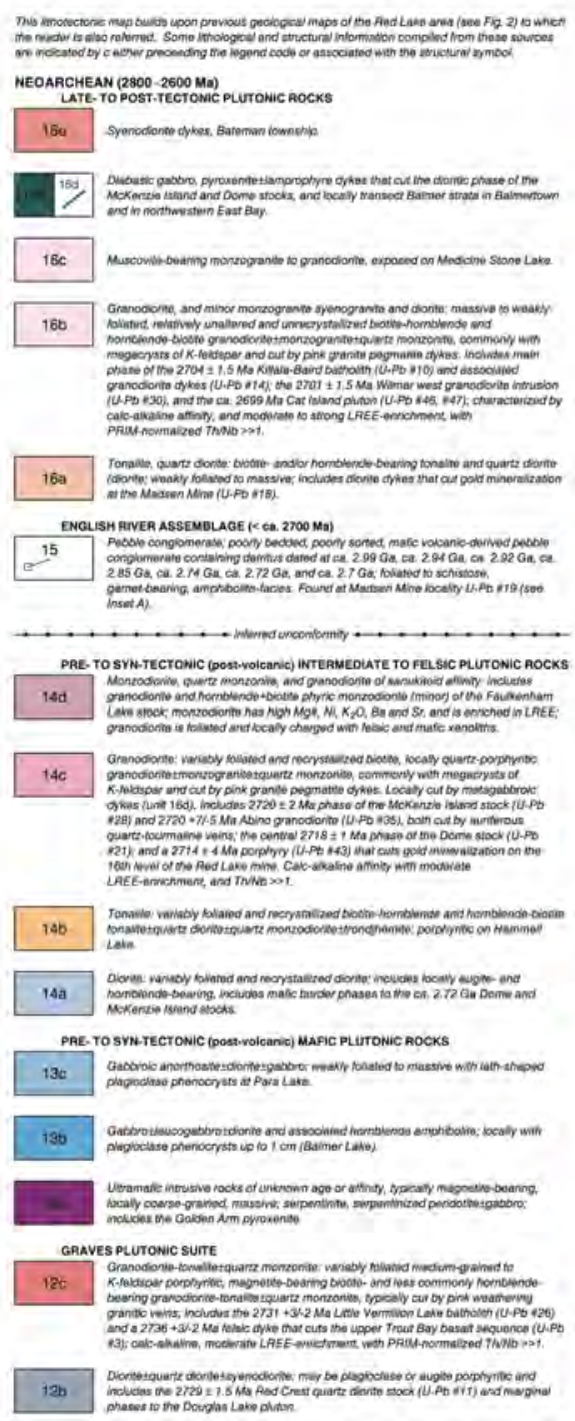

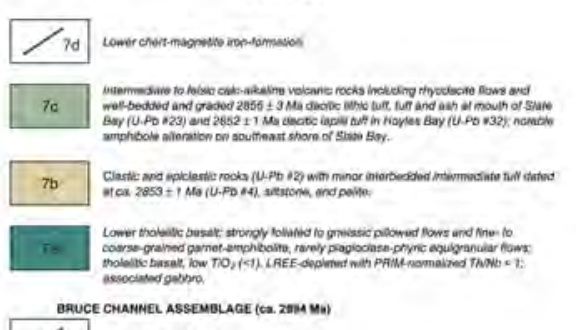

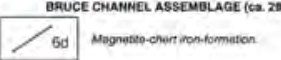

Bo.

ab.

6a. SLATE BAY ASSEMELAGE

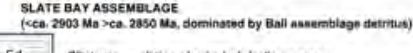

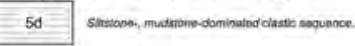

50 .

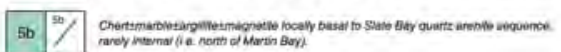

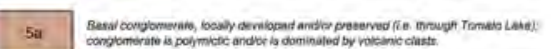

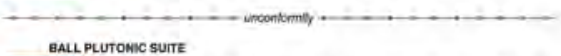

\section{BALl PLUTOMIC SUITE}

$+\infty$

D.

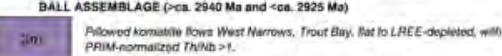

If.

3.

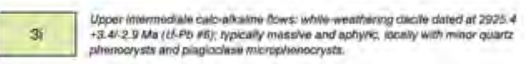

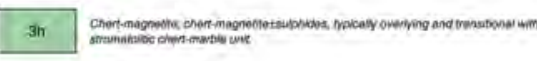

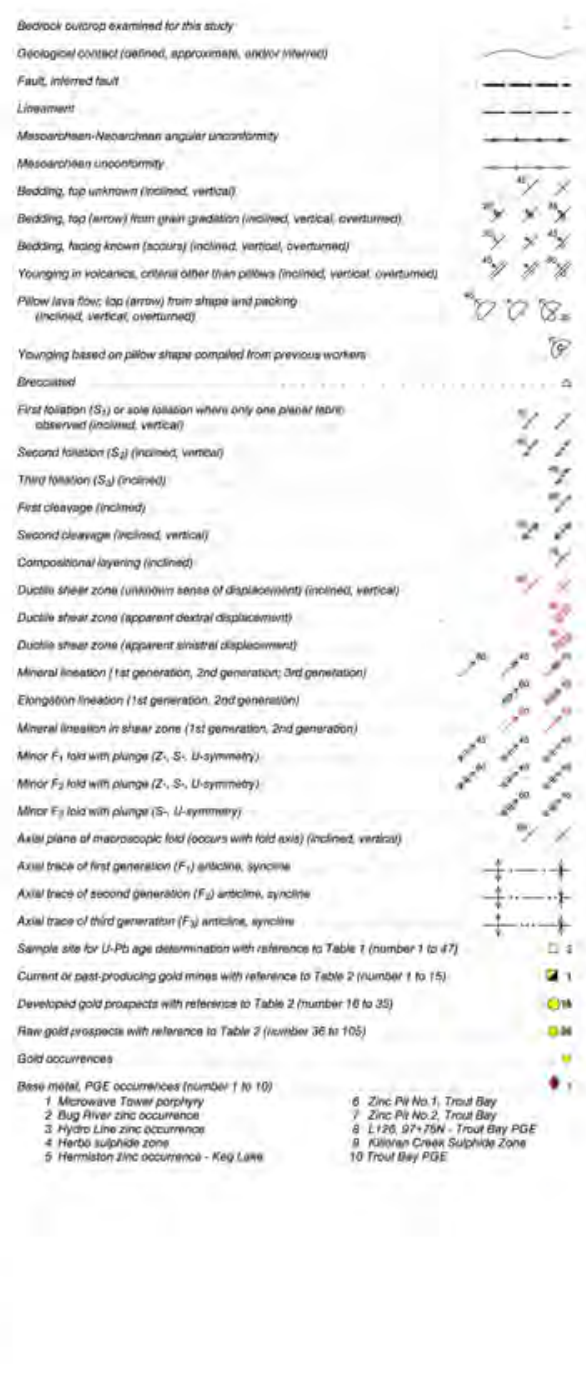

$4 \times 5$

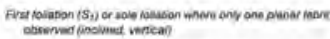

sempers

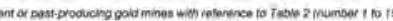

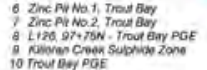

Figure 2.6 (Cont) - Legend for map in figure 2.2 (Sanborn-Barrie et al., 2004). 


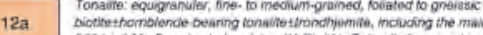

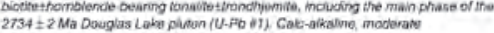
LFEE

RAVES ASSEMBLAGE (ca, $2733 \mathrm{Ma}$ )

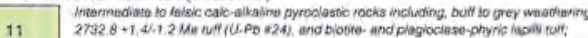
Wh low TO LATE

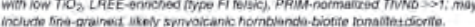

UUSTON ASSEMBLAGE ( $2742 \mathrm{Ma}>2733 \mathrm{Ma}$ )

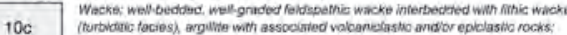

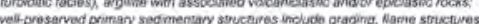
scour. and mud no up clasts; rare crossbencaing

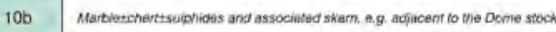

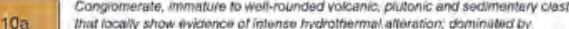
rom -

CONFEOERATION ASSEMBLAGE (Ca. 2748 to $2739 \mathrm{Ms}$ )

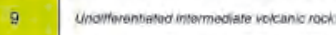

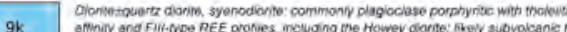

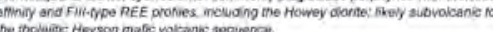
yson mafer voleanis: toquent

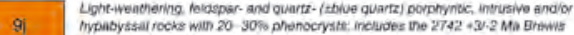

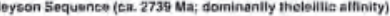

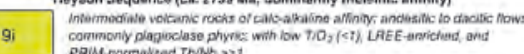

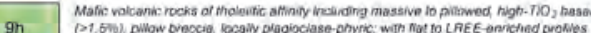

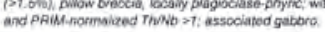

$9 g$

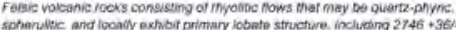

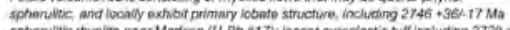

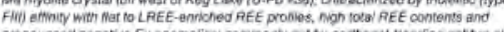

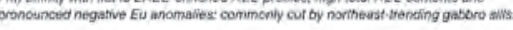

91

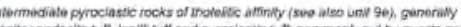

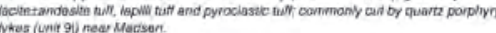

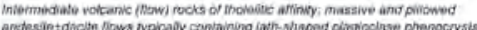

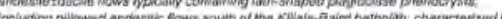

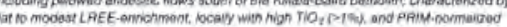
TWNO $>$ ?

Mcheely Sequence (ca. $2744-2742$ Ma; tominantly rsic-alkatine effinity)

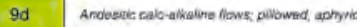

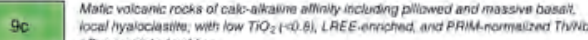

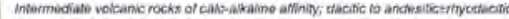

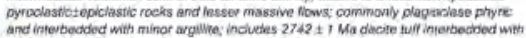

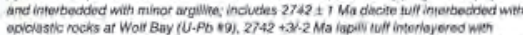

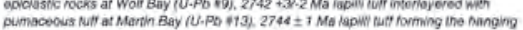

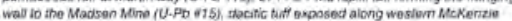

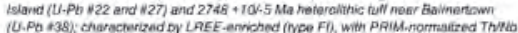

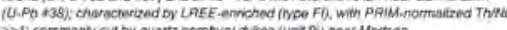

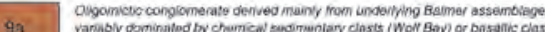

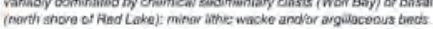

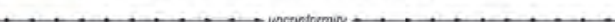

MESOAACHEAN (2999-2800 Ma)

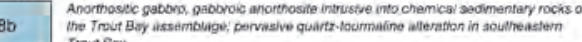

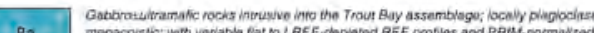

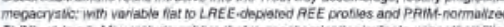

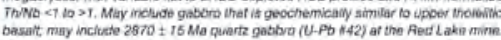

TROUT BAY ASSEMBLAGE (rea. 2853 Ma (lower basoit); <ea. $2853 \mathrm{Ma}$ (upper basait)

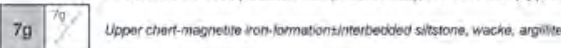

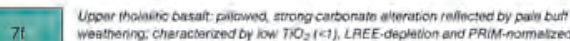

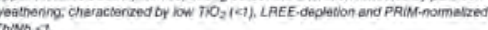

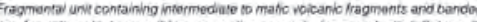

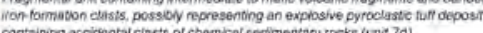
montaining accisiontal cinsts of chat

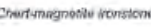

3

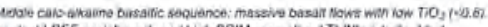

3d

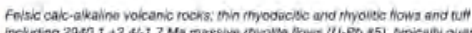

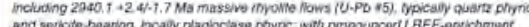

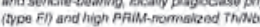

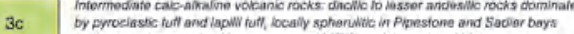
tsitstone, charactorized by proneunchd LAEE - anvichmont and high

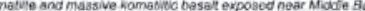

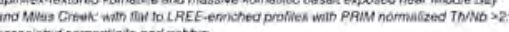

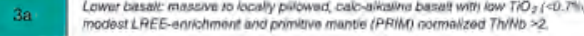

BALMEF PLUTONIC SUITE

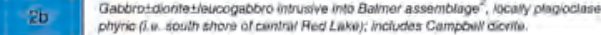

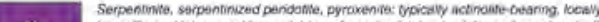

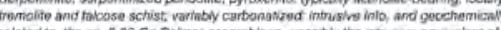

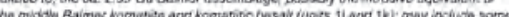

BALMER ASSEMBLAGE

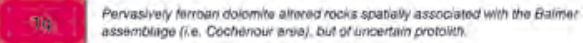

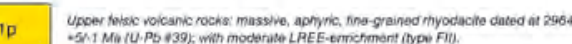

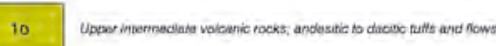

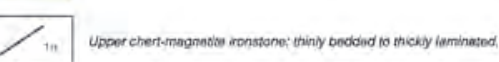

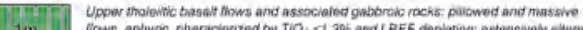

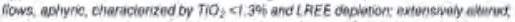
carbonate-cementod Drecolia abong north shore of central fied Lake may refoct cosse

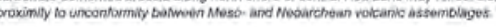

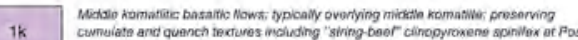

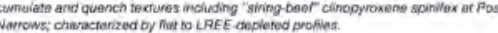

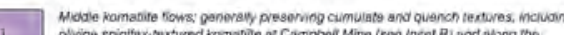

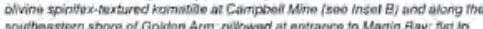

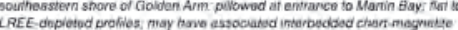
van-tomation iffiaher istandis.

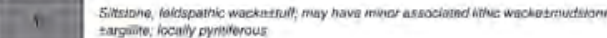

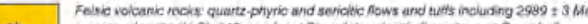

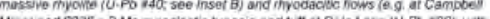

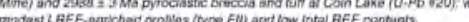

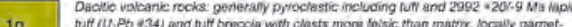

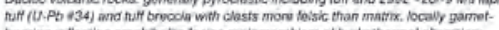

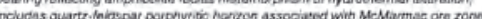

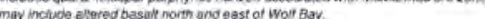

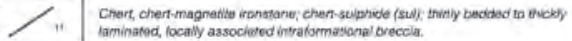

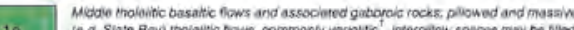

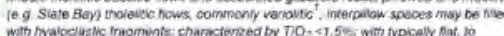

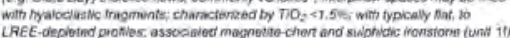

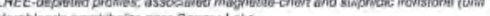

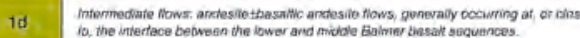

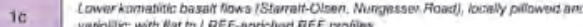

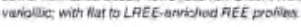

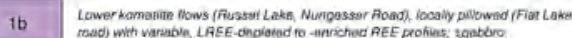

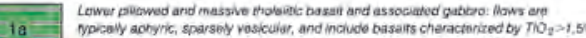

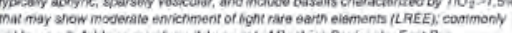

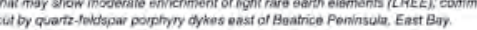

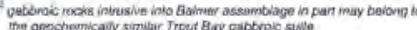

Figure 2.6 (Cont) - Legend for map in figure 2.2 (Sanborn-Barrie et al., 2004). 


\subsection{1 - Balmer Assemblage}

Tholeiite and komatiitic basalt of the Balmer assemblage are the oldest volcanic rocks in the RLGB. They form an extensive mafic-dominated volcanic assemblage and is the basal unit for the eastern and central regions of the RLGB (Fig. 2.2) (Sanborn-Barrie et al, 2004). Lithological and geochemical data indicate that the Balmer assemblage consists of lower, middle and upper sequences of massive to pillowed tholeiitic basalt that are separated by tuffs and komatiite-basalt flows that act as distinct marker horizons. The lowermost units in the Balmer assemblage are massive and pillowed, high- $\mathrm{TiO}_{2}$ tholeiites, with thin layers of pillowed komatiite lavas and komatiitic-basaltic flows. This unit is overlain by discontinuous andesitic flows, which appear to mark the transition from high to a middle layer of low $\mathrm{TiO}_{2}$ tholeiite sequences, which is characteristically pillowed and variolitic (Sanborn-Barrie et al, 2004).

The sedimentary rocks of the Balmer assemblage are dominated by thinly layered magnetite-chert ironstones, which occur at several stratigraphic levels, mostly in the middle tholeiitic basalt sequence. This middle sequence is topped by Intermediate to felsic flows and pyroclastic units (ca. 2.99 Ga) (Sanborn-Barrie et al, 2004). The middle section of the sequence is defined by thin horizons of massive komatiite and komatiitic basalt flows with preserved cumulate and quench (spinifex) textures as well as pillows. These komatiites are overlain by tholeiitic basalts (lowest $\mathrm{TiO}_{2}$ content, $<1.3 \%$ ) that are extensively altered and brecciated, particularly near the regional unconformity with the overlying $\sim 2.74 \mathrm{Ga}$ Confederation assemblage (Sanborn-Barrie et al, 2004). 
The abundance of pillowed lavas in the Balmer assemblage indicates a subaqueous eruption environment in a sediment-starved marine basinal setting from $\sim 3.00$ Ga to $\sim 2.96 \mathrm{Ga}$ (Sanborn-Barrie et al, 2004). The isotopic values ( $\varepsilon_{\mathrm{Nd}}$ values) and LREE-enrichment of the Balmer assemblage reflect interaction/contamination with older sialic substrate, although no differentiated continental basement rocks have been identified in the Red Lake belt (SanbornBarrie et al, 2004).

\subsection{2 - Balmer Plutonic Suite}

The Balmer Plutonic suite, as defined by Sanborn-Barrie et al, (2004), contains two main intrusive events with the first being the East Bay Serpentinite and the second the Campbell gabbro/diorite. Both of these intrusions younger than the $\sim 2.99$ Ga Balmer volcanic succession and older than the deposition of the Ball assemblage at $\sim 2.94 \mathrm{Ga}$ (Sanborn-Barrie et al., 2004). The Serpentinite unit has been identified to be older than the Campbell Gabbro/Diorite from crosscutting relationships and is geochemically similar to the Balmer volcanics, but the origin of this unit is still unknown and this interpretation is contested (Epp, Pers. Comm).

The East Bay Serpentinite (EBS) is a highly strained rock unit that extends from the northeast end of EB to the southwest to the Cochenour-Willans mine area ( $16 \mathrm{~km})$. This unit defines the EBDZ, a continuous and highly deformed domain that formed during to post- $\mathrm{S}_{1}$ deformation and has well defined fabrics and alteration. This unit can range from a serpentinite, serpentinized peridotite, and pyroxenite with all these rocks typically bearing actinolite, local tremolite, talc, and 
variable amounts of carbonate minerals (Sanborn-Barrie et al., 2004). This unit intrudes into the Balmer assemblage.

The Campbell-type gabbros/diorites also intrude into the Balmer assemblage, but are not as extensive as the EBS. The gabbros/diorites occur as boudinaged or elongate bodies parallel to the EBDZ. The rock types in this unit vary between gabbro, diorite, and leucogabbro, which intrude adjacent to the EBS in several areas (Sanborn-Barrie et al., 2004).

\subsection{3 - Granitic Plutonic Rocks}

There are two groups of plutonic rocks present in the East Bay area and both seem to have been emplaced during the pre- to syn-tectonic time frame. The Beatrice Tonalite, located at Beatrice point, is much more extensive at depth (Goldcorp Internal Report). The fabric in this unit has variable intensity and recrystallization, producing several altered rock types within the tonalite, such as biotite-hornblende-altered tonalite (Sanborn-Barrie et al., 2004). This unit varies compositionally across the exposed area due to differentiation of melts producing zones of quartz diorite, quartz monzonite, and trondjhemite (Sanborn-Barrie et al., 2004).

The second group of intrusive rocks is granodiorites that are prominent in the eastern portion of the Red Lake belt. Several granodiorites of the same age occur in the eastern RLGB (Dome stock and McKenzie stock) including the Abino Granodiorite that occurs in East Bay (Fig. 2.6). All three granodiorites have similar $\mathrm{U}-\mathrm{Pb}$ ages with the central Dome stock, the McKenzie stock, and the Abino 
Granodiorite yielding an age of $\sim 2.72$ Ga. The Abino Granodiorite is an elongate intrusion with the major axis parallel to the EBDZ (along the west shore of East Bay; Sanborn-Barrie et al., 2004). The Abino Granodiorite is variably deformed by $\mathrm{D}_{3}$ and contains recrystallized biotite and locally occurring feldspar megacrysts that produce compositional zonation of the granodiorite. Pink pegmatite dykes and gabbro dykes intrude this unit. Both the McKenzie stock and the Abino Granodiorite are crosscut by late stage (post $\mathrm{D}_{3}$ ) auriferous quartz-tourmaline veins. A porphyritic granodiorite is present underground at the Red Lake mine with an age of $\sim 2.71 \mathrm{Ga}$ and crosscuts the main gold mineralization, indicating the intrusion of granitic melts post-ore formation (Sanborn-Barrie et al., 2004). 
Table 2.3 - Summary of the characteristics and ages of the major intrusive bodies and minor dykes/stocks and their relationship with gold mineralization. Intrusive bodies with surface area greater than $100 \mathrm{~km}^{2}$ are denoted by * Reported ages are based on U-Pb dates of zircon and titanite. (Modified after data from Parker, 2000).

\begin{tabular}{|c|c|c|}
\hline \multicolumn{3}{|c|}{ Pre/Syn-Ore Intrusive Rocks } \\
\hline Unit & Age & Description \\
\hline $\begin{array}{l}\text { Mckenzie } \\
\text { Stock* }\end{array}$ & $2720 \pm 2 \mathrm{Ma}$ & $\begin{array}{l}\text { Granodiorite stock with ultramafic xenoliths and augite porphyritic } \\
\text { diorite-gabbro. Hosts gold mineralization associated with quartz- } \\
\text { tourmaline veins (Corfu and Andrews, 1987). }\end{array}$ \\
\hline Dome Stock* & $2718 \pm 1 \mathrm{Ma}$ & $\begin{array}{l}\text { Granodiorite and augite porphyritic diorite and gabbro (Corfu and } \\
\text { Andrews, 1987). }\end{array}$ \\
\hline $\begin{array}{l}\text { Abino } \\
\text { Granodiorite }\end{array}$ & $2720 \pm 6 \mathrm{Ma}$ & $\begin{array}{l}\text { A few to tens of meters wide and elongated with a northeast strike. } \\
\text { Medium to coarse-grained, homogenous. Contains numerous } \\
\text { mineralized quartz veins }(5-100 \mathrm{~cm}) \text { as well as late minor quartz- } \\
\text { tourmaline veins (cms) (Corfu and Andrews, 1987). }\end{array}$ \\
\hline $\begin{array}{l}\text { Hammel Lake } \\
\text { Batholith* }\end{array}$ & $2717 \pm 2 \mathrm{Ma}$ & $\begin{array}{l}\text { Monzogranite rich in K-feldspar and quartz that is associated with an } \\
\text { anorthositic intrusion (McMaster, 1987). }\end{array}$ \\
\hline \multicolumn{3}{|c|}{ Post-Ore Intrusive Rocks } \\
\hline Unit & Age & Description \\
\hline $\begin{array}{l}\text { Feldspar } \\
\text { porphyry } \\
\text { granodiorite } \\
\text { dikes }\end{array}$ & $2714 \pm 4 \mathrm{Ma}$ & $\begin{array}{l}\text { Few meters wide, strike east to east-southeast, dip steeply and contain } \\
\text { ample feldspar phenocryst }(3-5 \mathrm{~mm}) \text { with } 2-4 \% \text { quartz }(1-2 \mathrm{~mm}) \text { and } \\
\text { disseminated biotite. They are generally intermediate in composition } \\
\text { and are barren (Dubé et al., 2004). }\end{array}$ \\
\hline $\begin{array}{l}\text { Killala-Baird } \\
\text { Batholith* }\end{array}$ & $2704 \pm 1.5 \mathrm{Ma}$ & $\begin{array}{l}\text { Monzogranite with abundant K-feldspar, quartz, diorite, and } \\
\text { granodiorite xenoliths. The batholith has a magnetite-bearing } \\
\text { marginal phase (Corfu and Andrews, 1987). }\end{array}$ \\
\hline $\begin{array}{l}\text { Lamprophyre } \\
\text { dikes }\end{array}$ & $2701 \pm 3 \mathrm{Ma}$ & $\begin{array}{l}\text { Meter thick; contains greyish-brown to black biotite and amphibole, } \\
\text { chilled margins and clearly cut iron carbonate } \pm \text { quartz veins and gold } \\
\text { mineralization. Red Lake mine has } 4 \text { sets of lamprophyre dikes with } \\
\text { three being mesocratic and the fourth being calc-alkaline in } \\
\text { composition (Dubé et al., 2004). }\end{array}$ \\
\hline $\begin{array}{l}\text { Pink } \\
\text { Granodiorite }\end{array}$ & $2701+2 /-1 \mathrm{Ma}$ & $\begin{array}{l}\text { Found in the Red Lake Gold Mine. } 1.5 \text { meters wide, contains feldspar } \\
\text { and quartz phenocrysts }(2-3 \mathrm{~mm}) \text { in a quartz-feldspar matrix with } 5 \% \\
\text { biotite. Unit is commonly bleached and cuts across all lithological } \\
\text { units (Dubé et al., 2004). }\end{array}$ \\
\hline $\begin{array}{l}\text { Walsh Lake } \\
\text { Pluton* }\end{array}$ & $2699 \pm 1 \mathrm{Ma}$ & $\begin{array}{l}\text { K-feldspar-rich monzogranite with abundant quartz. It is rich in } \\
\text { diorite or granodiorite xenoliths with an oxidized phase near Ranger } \\
\text { Lake having a broad magnetic anomaly (Noble 1989). }\end{array}$ \\
\hline $\begin{array}{l}\text { Granodiorite } \\
\text { dikes }\end{array}$ & $2698 \pm 2 \mathrm{Ma}$ & $\begin{array}{l}\text { Found at Madsen and Starratt-Olsen Mine. Fine-grained, grey, } \\
\text { massive, } 1-2 \mathrm{~m} \text { wide granodiorite dyke. Overprinted with the late } \\
\text { auriferous quartz-sericite-pyrite veins (Dubé et al., 2004). }\end{array}$ \\
\hline
\end{tabular}




\subsection{4 - The East Bay Deformation Zone (EBDZ)}

The "East Bay Deformation Zone" is a continuous and highly disjointed $\mathrm{D}_{1}$ structural domain with a NE trend (EBT) defined by a highly strained serpentinite unit (East Bay Serpentinite) that can be traced from the north end of East Bay at Pineridge Road to the southwest to the Cochenour-Willans mine area (Dumoulin, 2009). To the southwest, the EBDZ is intersected by the southeast trending $D_{2}$ deformation zone (Mine Trend), which hosts the RLGM (Fig. 2.3). The fabric within the EBDZ is dominantly north-northeast trending $\left(\sim \mathrm{Az} 040^{\circ}\right)$ and steeply dipping $\left(\sim 75^{\circ}-90^{\circ}\right)$ to the northwest, which embodies fabric development during both $\mathrm{D}_{1}$ and $\mathrm{D}_{2}$ (Dumoulin, 2009). Outcrops in the hanging-wall (NW) of mafic volcanic rocks (Balmer assemblage) suggest that rock units host a series of smaller NW-trending folds contributing to a complexly folded stratigraphy (Couture, 2003). It has been suggested that the EBDZ acted as a "decollement" that accommodated differential shortening in the footwall volcanics to produce the NW-trending fold pattern recognized in the vicinity of the RLGM, however this has not been confirmed by recent studies (Couture, 2003).

The EBDZ is a 400-450m-thick zone of heterogeneous strain and strongly interlayered mafic and ultramafic units. The high-strain zone is intruded by a variety of altered dikes ranging in composition from ultramafic to felsic with strongly silicified zones. Contacts with the mafic volcanic rock packages that surround the serpentinite are sharp and marked by narrow (10-50m) high-strain zones/corridors with the strain primarily exhibited in the ultramafic rocks (Couture, 2003). 
The southeastern margin of the EBDZ consist of ultramafic schists and breccias containing rounded fragments of carbonate veins in an aphanitic, talcose and chloritic matrix (Dumoulin, 2009). The rocks along the northwest margin are comparatively more heterogeneous and irregular due to extensive deformation. Ultramafic rocks located along the NW contact of the EBDZ display more distinct magnetic susceptibility and this is supported by airborne magnetics (Fig. 2.4; Couture, 2003).

Only one fabric $\left(\mathrm{S}_{1}\right)$ is recognized in rocks of the EBDZ and it trends uniformly NE and have a steep dip $\left(\sim 90^{\circ} \pm 10^{\circ}\right.$; Couture, 2003). Boudin and smallscale folds in deformed hydrothermal veins are orthogonal to this foliation and suggests that the dominant transport direction during the formation of the foliation fabric was dip-slip, not strike-slip (Couture, 2003). 


\section{Chapter 3 - Methodology}

\section{1 - Mapping}

Exposure in the Red Lake belt is sparse with the bulk of the outcrop having been previously mapped (Sasseville \& Chantigny, 2002; Sanborn Barrie et al., 2004). Consequently the aim of the field mapping was to ground truth previously mapped lithologies and identify the dominant structures along the EBT. The general $\mathrm{D}_{1}$ and $D_{2}$ fabrics that have been previously identified are evident throughout the EB. Lithologies present on outcrops are generally correctly portrayed in previous mapping with few discrepancies and will require further information from drilling and/or stripping to properly correct lithological errors. Areas of overburden are where the greatest knowledge gaps exist and require new data.

\section{2 - Sample Selection}

Approximately 250 samples were collected in 2011 and ranged from country rocks, auriferous veins, barren veins, altered rocks, and rocks show foliation fabrics. Mineralized zones represent half of the samples along EB and were collected from drill core, as these deposits have no surface expression. Drill logs were acquired and examined to determine which holes and intervals should be sampled for the study, providing the best representation of veining. Outcrops have the advantage over unoriented core in that they demonstrate structures and fabrics that could not be directly measured in the core. The outcrops also contain a variety of veins, some of which are weakly auriferous and some that are completely barren. This variety of veins and fabrics were sampled with a channel saw during the 2011 field season. 
Samples collected in outcrop were typically 8 to $15 \mathrm{~cm}$ wide and 15 to $50 \mathrm{~cm}$ in length.

Thin sections and fluid inclusion plates were prepared and samples were micro-drilled for bulk stable isotopic analysis. Thin sections were also imaged and cut for U-Pb age dating using a SHRIMP II. The location, gold content, mineralogy and analytical methods used for each sample in this study are summarized in appendix A.

\section{3 - Optical Microscopy}

Seventy-two of the 250 samples were studied using transmitted and reflected light microscopy (Nikon Eclipse 50i POL polarizing microscope) to determine the mineralogy, mineralogical textures, alteration mineralogy, and paragenesis. Optical analysis was used to locate particular areas of interest for further studies on the scanning electron microscope (SEM), electron micro-probe (EMP), fluid inclusion analysis, secondary ion mass spectrometer (SIMS), and the sensitive high-resolution ion microprobe (SHRIMP). Images of the samples were captured using Nikon NIS Elements F 3.0 software.

\section{4 - Cathodoluminescence}

A variety of samples with quartz and carbonate veins were analyzed using cathodoluminescence to identify if there was one, or separate phases of crystal growth (separate veins). Work was performed on a Nikon Optiphot microscope equipped with a Technosyn Cold Cathode Luminescence model $8200 \mathrm{Mk}$ II 
cathodoluminescence unit. Several slides of vein material were examined using x5 and x10 objectives that identified the homogeneity of vein material and if there were multiple growth phases.

\section{5 - Scanning Electron Microscopy (SEM) and Energy Dispersive Spectroscopy (EDS)}

Samples were examined with the scanning electron microscope (SEM) on a Cambridge Stereoscan 120. Samples received a thin carbon coating to ensure good conductivity during examination. The SEM is equipped with a backscatter electron detector and an energy dispersive X-ray spectrometer (EDS) allowing for semi qualitative elemental abundances. The SEM was used to identify minerals and textural features, provided by EDS analysis, to supplement petrography. The SEM was also helpful to determine sulphide composition and the affinity between different sulphides and Au in the samples. The SEM aided in determining areas of potential interest for quantitative electron microprobe analysis (EMPA) analysis. The thin sections were scanned at high resolution to provide a detailed map of the minerals within the thin section.

\section{6 - Electron Microprobe (EMP)}

Quantitative analysis of tourmaline and sulphide minerals was carried out using the Cameca SX100 electron microprobe with PGT (Princeton-Gamma-Tech ) energy dispersive spectrometer equipped with 5 wavelength dispersive spectrometers. Tourmaline in 4 samples from 2 localities of the EBT was analyzed. 
The instrument operated at an acceleration voltage of $15 \mathrm{keV}$ with a $40 \mathrm{nA}$ current and a beam size of $10 \mu \mathrm{m}$. A total of 13 elements were analyzed and are as follows: $\mathrm{Na}, \mathrm{Al}, \mathrm{Si}, \mathrm{Ca}, \mathrm{F}, \mathrm{Mg}, \mathrm{K}, \mathrm{Fe}, \mathrm{Mn}, \mathrm{Ti}, \mathrm{V}, \mathrm{Cr}$, and B. Sulphides were analyzed from 5 samples, covering the entire East Bay Trend. The instrument operated at an acceleration voltage of $20 \mathrm{keV}$ with a $20 \mathrm{nA}$ current and a beam size of $1 \mu \mathrm{m}$. A total of 11 elements were analyzed and are as follows: $\mathrm{S}, \mathrm{Fe}, \mathrm{Ni}, \mathrm{Cu}, \mathrm{As}, \mathrm{Cd}, \mathrm{Au}, \mathrm{Ag}, \mathrm{W}, \mathrm{Pb}$, $\mathrm{Te}$, and $\mathrm{Zn}$. All elements had a detection limit of $<500 \mathrm{ppm}$, with the exception of fluorine $(<3500 \mathrm{ppm})$, boron $(<2500 \mathrm{ppm})$, gold $(<1700 \mathrm{ppm})$, arsenic, cadmium, and lead (all $<1100 \mathrm{ppm}$ ). The elements and their respective standards are indicated in Table 3.1. Major elemental analysis of these minerals is presented in Appendix C.

The EMPA was also used for chemical and textural mapping of titanite and rutile for $\mathrm{U}-\mathrm{Th}-\mathrm{Pb}$ geochronology. Detailed mapping was required to determine location and composition for SHRIMP analysis. For titanite imaging the instrument was operated at an acceleration voltage of $15 \mathrm{keV}$ with a $20 \mathrm{nA}$ current for back scattered electron (BSE) imaging, whereas a $10 \mathrm{nA}$ current was used for chemical mapping of minerals. 
Table 3.1 - Elements analyzed by EPMA and their respective standards.

\begin{tabular}{|c|c|c|c|c|c|}
\hline Element & Standard & Element & Standard & Element & Standard \\
\hline \multicolumn{6}{|c|}{ Tourmaline } \\
\hline Sodium & Albite & Aluminum & Andalusite & Silicon & Diopside \\
\hline Calcium & Diopside & Fluorine & Riebeckite & Magnesium & Olivine \\
\hline Potassium & Orthoclase & Iron & Fayalite & Manganese & Spessertine \\
\hline Titanium & Sphene & Vanadium & VP207 & Chromium & Chromite \\
\hline Boron & K326 & & & & \\
\hline \multicolumn{6}{|c|}{ Sulphides } \\
\hline Sulphur & Pyrite & Iron & Pentlandite & Nickel & Pentlandite \\
\hline Copper & Chalcopyrite & Arsenic & Cobalt & Cadmium & CdSe \\
\hline Cobalt & $\begin{array}{l}\text { Elemental } \\
\text { Cobalt }\end{array}$ & Gold/Silver & $\mathrm{Au}_{80} \mathrm{Ag}_{20}$ & Tungsten & $\begin{array}{l}\text { Elemental } \\
\text { Tungsten }\end{array}$ \\
\hline $\begin{array}{l}\text { Lead/ } \\
\text { Tellurium }\end{array}$ & PbTe & Zinc & $\mathrm{ZnS}$ & & \\
\hline
\end{tabular}

\section{7 - X-Ray Diffraction}

X-ray diffraction (XRD) analysis was carried out on a variety of samples to collect mineralogical data to supplement other analytical techniques. Initially three phyllosilicate samples (sericite, biotite, and fuchsite) were analyzed while preparing samples for Ar-Ar geochronology and later 5 carbonate samples were analyzed to determine compositions for stable isotope analysis. A sample of the quartztourmaline infilled black line faults was also analyzed to better determine 
composition. All samples were prepared as unoriented powder smear mounts for bulk mineralogical analysis (Zhang et al., 2003). All phyllosilicate samples were examined from $3-70^{\circ} 2 \theta$ and the carbonates were examined from $3-65^{\circ} 2 \theta$, all with a $0.052 \theta$ step width at 1 second per step. The majority of samples were prepared as smear mounts, but if enough material was available, a zero background quartz plate with a centre well was used. All samples were examined using a Siemens D5000 Diffraktometer X-ray Powder Diffractometer using a Siemens Kristalloflex X-5 x-ray generator. The $\mathrm{XRD}$ operated at $40 \mathrm{kV}$ and $30 \mathrm{~mA}$, while utilizing $\mathrm{CuK \alpha}$ radiation with a wavelength of $1.54 \AA$. Full results of these samples is presented in Appendix C.

\section{8 - Fluid Inclusions}

Fluid inclusions were studied using a FLUID INC., USGS-type, heating/freezing system at the University of Manitoba to measure the phase changes that occur upon rapid cooling and slow, even heating of samples. The system is equipped with a Doric Trendicator that is calibrated for temperatures from $-190^{\circ} \mathrm{C}$ to $700^{\circ} \mathrm{C}$. The trendicator is used in conjunction with a thermocouple to measure the temperature within the sample chamber to an accuracy of $0.1^{\circ} \mathrm{C}$. In order for the Trendicator to identify that a given voltage potential from the thermocouple corresponds to a specific real temperature, the Trendicator must be calibrated at three points: a zero point, a point along the negative slope of the voltage-temperature curve, and a point along the positive slope of the voltagetemperature curve. The stage was calibrated before each use with synthetic fluid 
inclusion standards at $-56.6^{\circ} \mathrm{C}\left(\mathrm{CO}_{2}\right), 0.0^{\circ} \mathrm{C}$ and $374.1^{\circ} \mathrm{C}\left(\mathrm{H}_{2} \mathrm{O}\right)$. The FLUID INC. stage is expected to provide an accuracy of $\pm 1.0^{\circ} \mathrm{C}$ for total homogenization (from 100 $\left.450^{\circ} \mathrm{C}\right), \pm 0.2^{\circ} \mathrm{C}$ for $\mathrm{CO}_{2}$ melting temperatures and $\pm 0.1^{\circ} \mathrm{C}$ for ice and clathrate melting. Calibration was typically within these limits, indicating valid measurements were recorded. A summary of fluid inclusion results is presented in section 4.4 and all data is displayed in Appendix D.

Inclusions were measured and examined using the fluid inclusion assemblage (FIA) techniques to get representative data, however this was not always possible due to limited presence of quality primary inclusions. Fluid inclusions were studied from the quartz veins in a variety of samples with most samples only containing one generation of quartz, but in some cases multiple generations of veining (including carbonate) are present.

Once the melting and homogenization temperatures were acquired from cooling and heating analysis, salinity was determined from the inclusion data

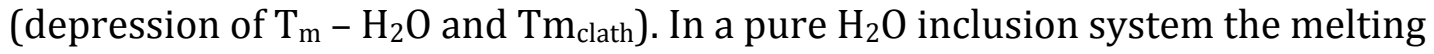
temperature would be $0.0^{\circ} \mathrm{C}$, except very few natural systems contain only water. One of the key components of inclusion composition is the $\mathrm{H}_{2} \mathrm{O}$ - salt system of these fluids (Bodnar, 2003). Therefore, the freezing point of water is directly proportional to the salt content causing a depression of the freezing point (Fig. 3.1; Gleeson, 2003). Numerous salts are present in nature; the most prevalent is $\mathrm{NaCl}$ allowing it to be used as a standard, displaying inclusion salinities as weight $\% \mathrm{NaCl}$. The microthermometric data was then inputted into the FLUIDS and CLATHRATES 
software packages of Bakker $(1997,2003)$ to determine salinity for the various fluid inclusion assemblages.

(Removed due to Copyright)

Figure 3.1 - Depression of the freezing point of pure water as a function of the weight $\%$ of salt in solution for $\mathrm{NaCl}, \mathrm{KCl}, \mathrm{CaCl}_{2}$ and $\mathrm{MgCl}_{2}$ (Shepherd et al., 1985).

\section{9 - Raman Spectroscopy}

Raman spectroscopy was carried out at the University of Manitoba using a HORIBA Jobin Yvon LabRAM ARAMIS confocal spectrometer. Analysis was carried out on 4 fluid inclusion slides that are 500 microns thick measuring fluid inclusions that have a diameter of 10-30 microns. The spectrometer was calibrated prior to each measurement using the first-order Raman peak of crystalline silicon $\left(520 \mathrm{~cm}^{-}\right.$ 1). Spectrums were acquired using a high-stability, low-noise mpc6000 laser emitting at $532.06 \mathrm{~nm}$ laser. Spectra were collected in a confocal mode with a Olympus M-Plan 100x 0.9 N.A. objective lens and a 100 micrometre confocal 
aperture at a 600 groove/mm grating. Other instrument parameters were adjusted to produce an optimal spectrum and signal (Burruss, 2003).

\subsection{0 - Gas-Source Mass-Spectrometry}

Carbonates were analyzed for their carbon and oxygen isotopic compositions at the G.G. Hatch Stable Isotope Laboratory at the University of Ottawa. Carbonate veins from various samples were micro-drilled, producing a fine powder. Each sample comprised an average of $\sim 55 \mathrm{mg}$ of powder, enough for several analyses. Samples were generally composed of ferroan dolomite or ankerite, with very minor amounts of calcite.

The G.G. Hatch Stable Isotope Lab has a carbonate line that uses continuous flow on a Thermo Finnigan Gas Bench that is coupled to a DeltaPlus XP Isotope Ratio Mass-Spectrometer (IRMS). This IRMS is for high-precision measurement of the relative isotope abundances of $\mathrm{C}, \mathrm{N}, \mathrm{O}, \mathrm{S}, \mathrm{H} / \mathrm{D}$, as well as for the determination of atmospheric gas ratios. The ion source is a high sensitivity, self-aligning gas tight electron impact ion source that is optimized for $\mathrm{CO}_{2}, \mathrm{~N}_{2}, \mathrm{SO}_{2}$ as well as for $\mathrm{H} / \mathrm{D}$ measurements with extremely low and stable $\mathrm{H}_{3}+$ abundance. Accelerating voltage was $3 \mathrm{kV}$.

For each sample, two aliquots were run and the carbon and oxygen isotope ratios of these two aliquots were compared later to see if they were within the accepted range ( 0.1 and 0.2 per mill for ${ }^{13} \mathrm{C}$ and ${ }^{18} \mathrm{O}$, respectively). Vessels containing one of three isotopically different reference materials were also interspaced among the samples with at least one set of reference materials for every 
eight unknowns that was analyzed (Revesz et al., 2001). The process of analysis was carried out using the Isotope Data (ISODAT) computer program. Complete results for carbonate isotopes are listed in appendix E.

\subsection{1 - Secondary Ion Mass Spectrometry (SIMS)}

Stable isotope compositions of quartz, tourmaline and sulphide minerals were measured using a CAMECA IMS $7 \mathrm{f}$ secondary ion mass spectrometer (SIMS) at the University of Manitoba. Areas of interest based on petrography, fluid inclusion, and electron microprobe analysis were cut from a variety of fluid inclusion slides $(500 \mu \mathrm{m})$ and thin sections. These samples were carefully selected and mounted in epoxy-resin and left overnight to set, forming a circular puck. Prior to analysis, each sample was subsequently cleaned using soap, then immersed in an ultrasonic cleaner that followed a progression through dilute soap solution, distilled water, and then ethanol, spending approximately 15 minutes in each solution. Once cleaning was complete, the samples were sputtered with a thin layer of gold to provide a conductive surface. Samples were placed in SIMS sample holders and kept under vacuum overnight.

Oxygen isotope ratios on quartz and quartz-tourmaline and sulphur isotope ratios on sulphides where obtained from analyzing 6-10 points during separate analytical sessions. The most homogenous areas within the sample were located for analyses within the quartz, tourmaline, and pyrite grains. Data is shown in appendix F for sulphur and oxygen, respectively. 


\subsubsection{Sulphur and Oxygen Isotopes}

The conditions for sulphur and oxygen isotope analysis by SIMS are similar. A cesium $\left(\mathrm{Cs}^{+}\right)$primary beam with a $2 \mathrm{nA}$ current was accelerated $(+10 \mathrm{kV})$ onto the sample surface with a sputtering diameter of $\sim 10 \mu \mathrm{m}$; the instrument operated at a $250 \mathrm{~V}$ offset for sulphur and $300 \mathrm{~V}$ offset for oxygen, $-5 \mathrm{kV}$ negative secondary accelerating voltage and at mass resolving power of 350. For detailed description of operating conditions see Riciputi et al. (1998) for sulphur isotope analysis and Fayek et al. (2002) for oxygen isotope analysis.

\subsubsection{Measurement of Standards and Unknowns}

During the measurement process by SIMS, an inherent mass-dependent bias is introduced, and is commonly referred to as instrumental mass-fractionation (IMF), which typically favors the low mass isotope. The greatest contributor to the IMF is the ionization process, which is strongly dependent upon sample characteristics (i.e., mineral chemistry). This is referred to as compositionally dependent fractionation or "matrix effects" (e.g., Riciputi et al. 1998). Therefore, accurate isotopic analysis using SIMS requires that IMF be corrected for by standardizing the IMF using mineral standards that are compositionally similar to the unknown. SIMS results from the known standard are then compared to the accepted isotopic composition in order to calculate a correction factor. This correction may then be applied to the unknown samples that are being measured during the same analysis session (Fayek et al., 2002). Therefore, isotopically 
homogenous standards are crucial for data correction, but may be difficult to obtain depending on the mineral.

Isotopic species were detected sequentially by switching the magnetic field and measured ${ }^{16} 0+$ and ${ }^{18} \mathrm{O}+$ for oxygen in quartz and tourmaline and measured ${ }^{32} \mathrm{~S}+$ and ${ }^{34} \mathrm{~S}+$ in sulphides. A typical analysis lasted $\sim 10$ minutes for oxygen, comprising 70 cycles of analysis and approximately 8 minutes for sulphur comprising 60 cycles.

\subsubsection{Standard Material Selection and Grain Mount Preparation}

A homogeneous rose quartz crystal characterized at the University of Wisconsin (UWQ) with a $\delta^{18} 0$ value of $12.33 \pm 0.14 \%$ o (Kelley et al., 2007) was used as the standard for oxygen isotopic analysis of quartz. Two species of tourmaline were identified from microprobe analysis; therefore a standard for elbaite (98144) with a ${ }^{18} \mathrm{O} /{ }^{16} \mathrm{O}$ ratio value of 2.033 was used, along with a standard for dravite (108796), which has a ${ }^{18} \mathrm{O} /{ }^{16} \mathrm{O}$ ratio value of 2.026 . As for the analyses of sulphides, the Balmat pyrite standard was used with a $\delta^{34} \mathrm{~S}$ value of $15.1 \pm 0.3 \%$ from the Balmat metamorphosed massive sulphide deposit in New York. Spot-to-spot reproducibility ( $1 \sigma$ error) for UWQ, elbaite, dravite, and Balmat pyrite was $0.6,0.8$, 1.6 , and 0.3 , respectively. Precision for individual analyses was 1.0 and 1.2 for $\delta^{18} 0$ (UWQ and tourmaline, respectively) and 0.6 for $\delta^{34} \mathrm{~S}$ (Balmat pyrite). Therefore, $2 \sigma$ errors for oxygen (UWQ), oxygen (tourmaline), and sulphur isotope analysis are 1.0, 1.2 , and 0.6 , respectively.

All isotopic data are presented using standard $\delta$-notation and are presented 
in units per mil (\%) relative to the appropriate standards, Vienna Standard Mean Ocean Water (V-SMOW) for ${ }^{18} \mathrm{O} /{ }^{16} \mathrm{O}$ and Canyon Diablo Troilite (CDT) for ${ }^{34} \mathrm{~S} /{ }^{32} \mathrm{~S}$. The equation for calculating $\delta$ values in units of per mil (\%o) is:

$\delta_{\text {sample }}=\left(\mathrm{R}_{\text {sample }}-\mathrm{R}_{\text {std }} / \mathrm{R}_{\text {std }}\right) \times 10^{3}$

where $\mathrm{R}_{\text {sample }}$ and $\mathrm{R}_{\text {std }}$ are the absolute isotope ratios in sample and standard, respectively. Isotope ratios measured by SIMS were compared to the accepted ratios (calculated from $\delta$ values determined by conventional analyses and gas-source mass-spectrometry) for each mineral using equation [2]:

$\mathrm{R}_{\text {sample }}=\left[\left(\delta_{\text {sample }} / 10^{3}\right)+1\right] \mathrm{R}_{\text {std }}$

where $\mathrm{R}_{\text {std }}\left({ }^{18} \mathrm{O} /{ }^{16} \mathrm{O}\right)$ for V-SMOW is defined as $2.005 \times 10^{-3}$ (Kawabe, 1978) and $\mathrm{R}_{\text {std }}$ $\left({ }^{34} \mathrm{~S} /{ }^{32} \mathrm{~S}\right)$ for CDT is $4.450045 \times 10^{-2}$ (Jenson \& Nakai, 1962). These data can be used to calculate isotope mass fractionation that occurs during SIMS analysis by using equation [3]:

$\alpha \mathrm{SIMS}=\mathrm{R}_{\text {SIMS }} / \mathrm{R}_{\text {conv. }}$

where $\mathrm{R}_{\text {SIMS }}$ is the ratio measured by SIMS and $\mathrm{R}_{\text {conv }}$ is the accepted ratio measured 
by conventional gas-source mass-spectrometry. These ratios can be converted to \%o notation by:

$$
\delta_{\text {bias }}=\left[\left(\mathrm{R}_{\text {SIMS }} / \mathrm{R}_{\text {conv. }}\right)-1\right] \times 10^{3}
$$

\subsection{2 - SHRIMP II Geochronology}

The Sensitive High Resolution Ion Microprobe (SHRIMP) is a large-diameter, double-focusing secondary ion mass spectrometer sector instrument (Ireland et al., 2008). It has a variety of applications ranging from high resolution imaging to geochronology. U-Pb analysis in this study was conducted using a SHRIMP II instrument at the Research School of Earth Sciences (RSES) at the Australian National University.

Numerous thin sections were optically examined to identify prospective U-Pb datable minerals (e.g. zircon, titanite, rutile) within veins associated with mineralizing events. Suitable grains of titanite were located in polished thin section EB10040-5 along the altered rim of quartz veins, which was then imaged using a Cameca SX100 electron microprobe. Before analysis the sample was imaged in transmitted and reflected light and back-scattered electron (BSE) images were also collected of all prospective grains at a variety of scales for navigational purposes. Thin sections were trimmed to fit a $35 \mathrm{~mm}$ diameter mount and was mounted together with grains of the titanate standard BLR-1. The thin section and standard were polished to a smooth, common surface. The standard analytical protocols described by Williams (1998) were used. 
A primary $\mathrm{O}_{2}$ - beam was focussed onto the titanites producing a $\sim 15 \mathrm{~mm}$ diameter spot size appropriate for the target. The surface was rastered for 2.5 minutes before analysis in order to clean the surface of any contamination. Data acquisition was done by repeatedly stepping through the masses ${ }^{40} \mathrm{CaTi}_{2}{ }^{16} \mathrm{O}_{4}$ ("reference mass 200 "), ${ }^{204} \mathrm{~Pb}$, background at mass $204.04,{ }^{206} \mathrm{~Pb},{ }^{207} \mathrm{~Pb},{ }^{208} \mathrm{~Pb},{ }^{238} \mathrm{U}$, ${ }^{232} \mathrm{Th}$ and ${ }^{238} \mathrm{U}^{16} \mathrm{O}$ (mass 254 ), for 6 scans.

The data were reduced in a manner similar to that described by Williams (1998, and references therein), using the SQUID I Excel Macro of Ludwig (2001). The reference titanate BLR-1 (1050.5 $\pm 0.9 \mathrm{Ma}, 2 \mathrm{~s}$; Aleinikoff et al., 2007) was the primary $\mathrm{U}-\mathrm{Pb}$ geochronology calibration standards and the reference used to calibrate the $\mathrm{U}, \mathrm{Th}$, and $\mathrm{Pb}$ concentrations for the session (U concentration: 250 ppm; Aleinikoff et al., 2007). The decay constants recommended by the IUGS Subcommission on Geochronology (as given in Steiger and Jäger, 1977) were used in the age calculations.

Uncertainties given for individual U-Pb analyses (ratios and ages) are at the 1s level, however uncertainties in the calculated weighted mean ages are reported as $95 \%$ confidence limits and include the uncertainties in the standard calibrations where appropriate. For the age calculations, corrections for common $\mathrm{Pb}$ were made using the measured ${ }^{204} \mathrm{~Pb}$ and the relevant common $\mathrm{Pb}$ compositions from the Stacey and Kramers (1975) model. Concordia plots, regressions and any weighted mean age calculations were carried out using Isoplot/Ex 3.0 (Ludwig, 2003) and where relevant include the error in the standard calibration. 


\section{CHAPTER 4 - RESUltS}

\section{1 - Petrography}

Representative samples of host rocks, alteration zones and veins (barren and auriferous) were collected throughout the EB area. Petrographic observations on all 75 thin sections and fluid inclusion slides were carried out on the mineralogy of the host rocks, veins, and associated wall rock alteration.

Mafic and ultramafic volcanic rocks of greenschist-grade metamorphism host the majority of veins along the EBT. There are a few exceptions, such as the mafic dykes present in the Chevron area and the granodiorite-hosted veins at Abino Point. All the veins sampled fall into any of the following categories: carbonate, quartzcarbonate, quartz, quartz-tourmaline and quartz-actinolite veins. The host rocks are extensively altered along the margins of the veins and are primarily composed of aluminous minerals. A paragenetic sequence is presented in Figure 4.1 and was determined by crosscutting relationships and textures from outcrop, hand specimens, and thin sections.

Rubicon Minerals Corp owns the McFinley Mine area therefore, samples for this study were acquired from Duchesne, the Goldcorp property along the margin of Rubicon, which hosts what is considered the extension of the F2 zone. 


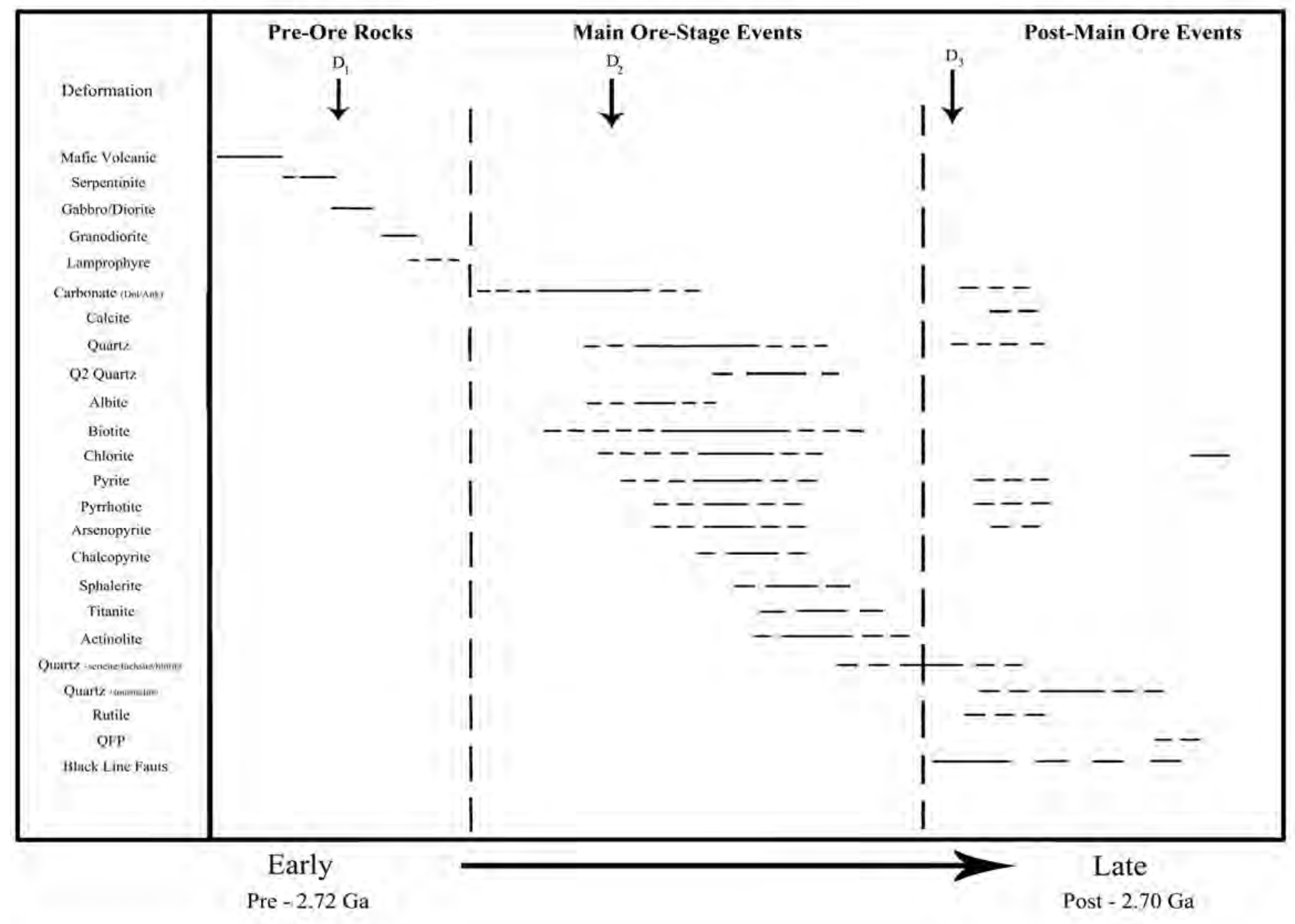

Figure 4.1 - Generalized paragenetic sequence divided into pre-ore rocks, main ore stage events, and post-ore events throughout the East Bay Trend 


\subsection{1 - Host Rocks}

In Red Lake, the majority of veins are restricted to the Balmer volcanic assemblage (chapter 2.3.1). This sequence is a succession of tholeiitic basalt to basaltic komatiite flows that have been subsequently altered by regional deformation, metamorphism, and numerous hydrothermal events (Fig. 4.2). Due to upper-greenschist metamorphism affecting the majority of the belt, most host rocks contain significant biotite and chlorite (Fig. 4.2B \& 4.2C). In addition, hydrothermal events have produced a significant degree of silicification and carbonatization throughout the EB area. Primary plagioclase, pyroxene, and amphibole are often present, but have been significantly overprinted or replaced from the rocks by the successive veining events in the EB area. 


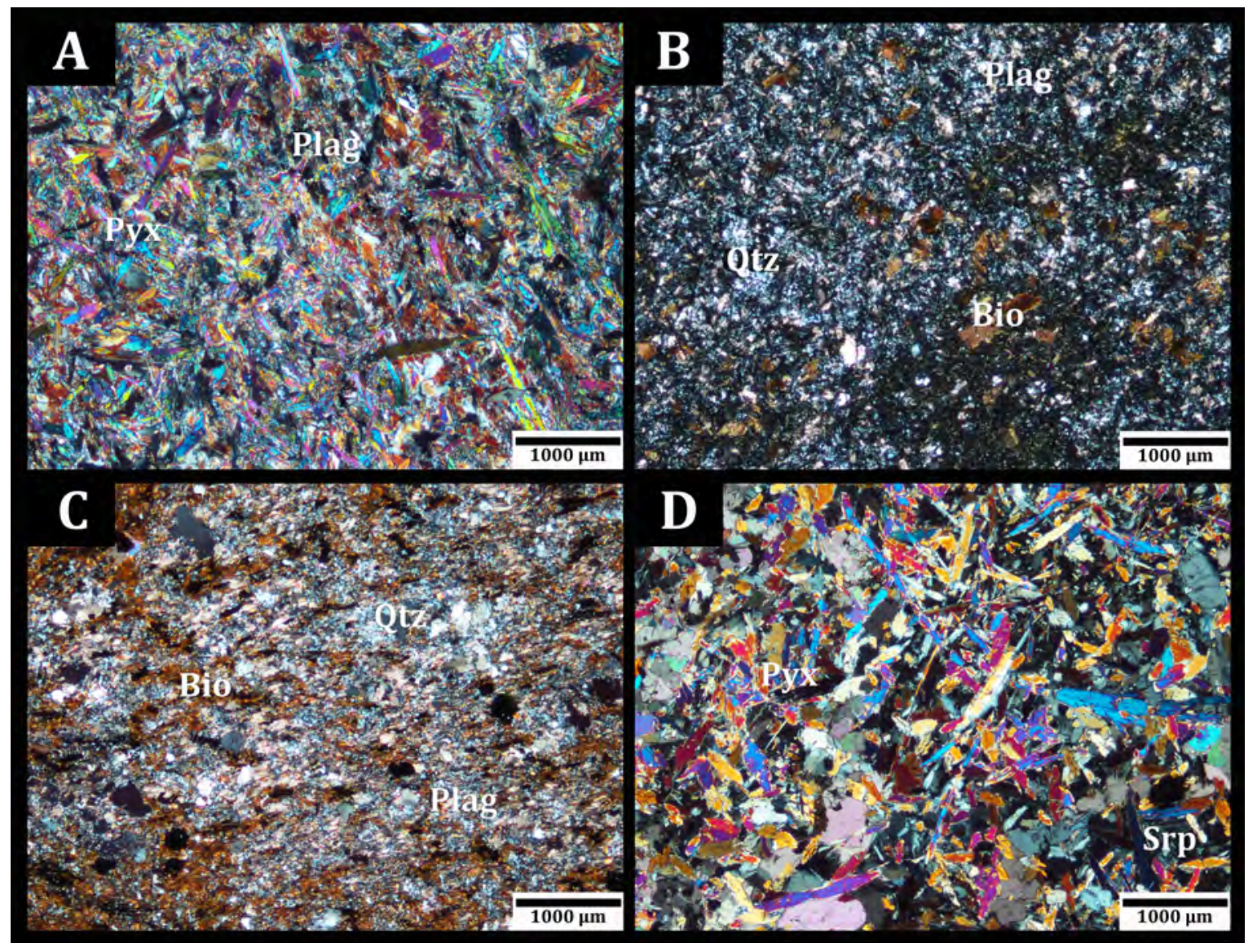

Figure 4.2 - Host rocks from the East Bay area. A) Weakly altered basalt; B) Silica and biotite-altered basalt; C) Strongly silicified and biotitized basalt; D) East Bay 'Serpentinite', originally this rock was a pyroxenite.

\subsection{2 - Early Carbonate Veins}

The earliest recognized vein type is the widespread Fe-dolomite or ankerite veins throughout the EB area (Fig. 2.3). These carbonate veins occur at various thicknesses, ranging from small $(\sim 1-2 \mathrm{~cm})$ veinlets, to large $(\sim 10-15 \mathrm{~m}$ wide) veins that are generally barren. There is generally two styles of carbonate veins: 1) colloform-crustiform to massive carbonate veins and, 2) brecciated carbonate veins.

The first group of veins is by far the most abundant throughout the EB area. 
They have a northeast-trend and dip moderately to steeply to the northwest. These veins are generally hosted within a few centimeters to metre-wide shear zones of foliated Balmer basalt, with veins commonly occurring subparallel to the $S_{1}$ foliation. Some veins may appear massive, but these veins generally have welldeveloped colloform-crustiform textures that are occasionally overprinted by carbonate breccia zones. There are several generations of these as indicated by flow banding textures that are present within the larger veins.

Carbonate breccia zones are the least abundant form of carbonate veining throughout the EBT and also follow the northeast trend of the EBDZ. Breccia zones can range from 1 to 8 metres across and possess cockade textures. Fragments are a variety of the earlier colloform carbonate and more commonly the mafic host rock.

Both vein types were overprinted by small $(1-4 \mathrm{~cm})$ calcite veins that occur in localized areas of Abino and McFinley. The calcite forms small stringers that intrude through fractures in the earlier carbonate veins.

\subsection{3 - Quartz Veins (Ore-Stage)}

The wide variety of quartz veins styles and their discontinuous nature makes it difficult to correlate between any two locales. Distinguishing between mineralized and barren quartz veins based on texture is also challenging (Fig. 4.3). Occasionally, auriferous quartz veins are overprinted by fine-grained quartz that is generally barren.

The early stage carbonate veins (Fig. 4.4A) are crosscut by a variety of quartz (Fig 4.4B), quartz-carbonate, and quartz-tourmaline veins. These veins have widths 
ranging between 0.25 and 2 metres, are continuous at the outcrop-scale, and have variable carbonate content ( $\sim 5-25 \%)$. The first generation of large, widespread quartz veins is barren, but in many areas they are crosscut by a late auriferous silicification event, similar to what occurs at the RLGM (Penczak \& Mason, 1997; Tarnocai, 2000; Dubé et al., 2001). Small quartz stringers characterize the main gold mineralizing event and silicification that is focused along similar structures that host early generations of quart-carbonate veins (Horwood, 1940).

Late auriferous veining events include quartz-actinolite veins (Fig. 4.4C) and the quartz-tourmaline veins (Fig. 4.4D). The quartz-actinolite veins are interpreted to have occurred during the waning stages of the main-ore fluid event at the RLGM, whereas quartz-tourmaline veins generally post-date the main gold mineralization (Penczak, 1996: Epp, pers comm, 2012; Marsden 2012).

Quartz-actinolite veins form extensive (>100 metres) zones of lens or podlike bodies that are commonly 1-6 metres wide, and are parallel to shear zones and faults (Marsden, 2012). Actinolite occurs as late, barren veinlets throughout the quartz, with gold typically occurring as free gold within the quartz phases yielding mineralized quartz-actinolite veins. These veins have only been identified as a principal vein type in the Cochenour and Duchesne/McFinley regions along the EBT, however they have also been known to occur internal to quartz veins at the RLGM.

Quartz-tourmaline veins are more prevalent than previously realized and can be found throughout most of the EB area (Fig. 4.5). These veins are typically narrow (1-30 cm), laterally continuous, and typically contain 2-10 vol \% fine-grained tourmaline. In some rare instances, tourmaline contents of these veins can 
occasionally be as high as 40-60 vol \%. They are commonly located within or adjacent to the early carbonate veins throughout EB, and are quite common throughout the RLGB. Elbaite and dravite are the most common types of tourmaline (Appendix F) and gold is present in quartz, typically as free gold. Gold grades are typically lower in quartz-tourmaline veins than in the earlier main ore-stage veins. The final hydrothermal events in the EB area are barren, and formed dolomite and quartz veins.

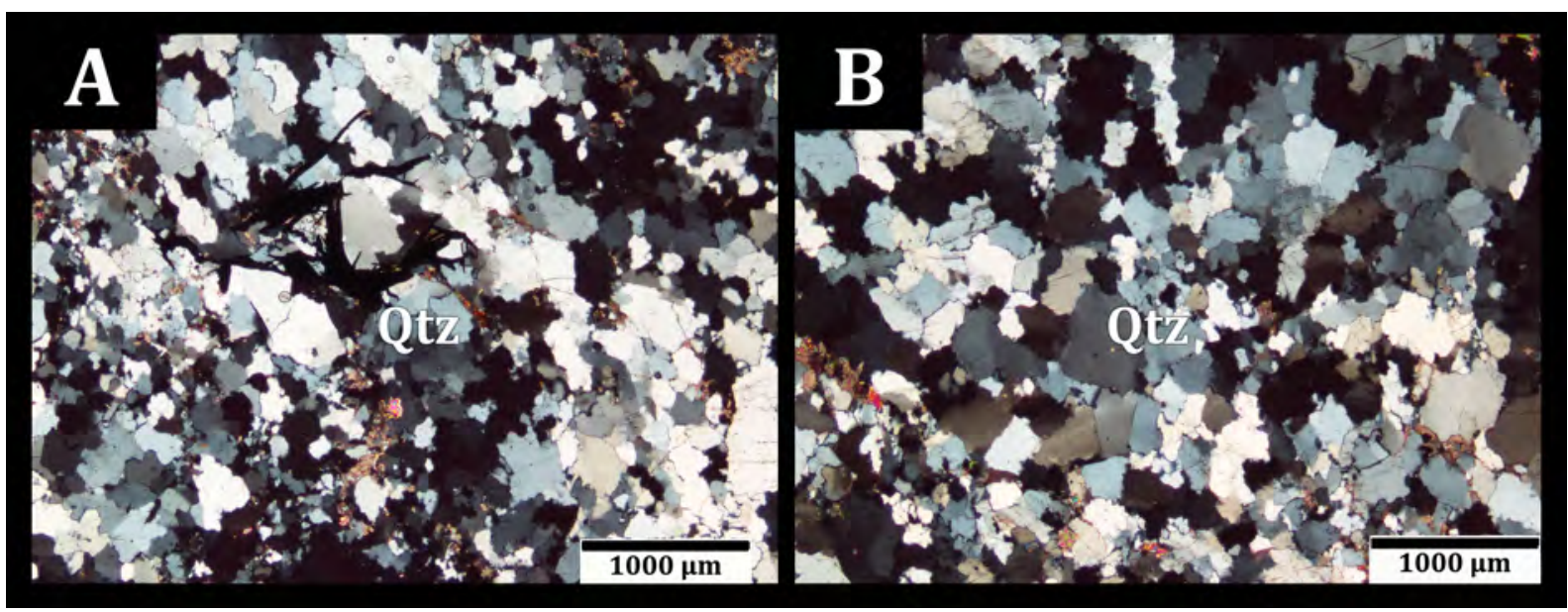

Figure 4.3 - Identical appearance between barren and auriferous quartz veins from Abino. A) Barren quartz vein; B) Auriferous quartz vein $(10.3 \mathrm{~g} / \mathrm{t})$ 


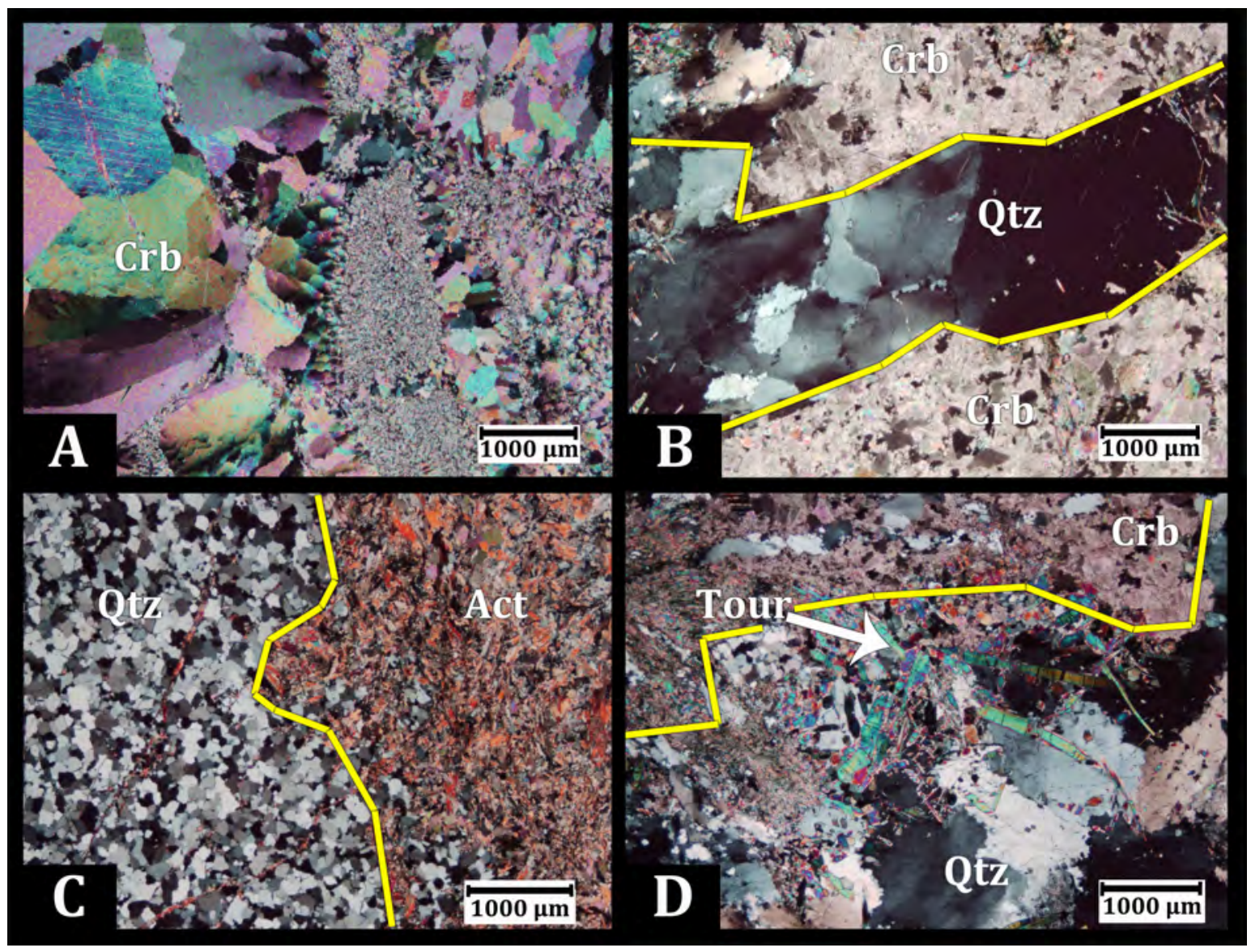

Figure 4.4 - Variety of vein types throughout the East Bay Trend. A) Colloform dolomite vein; B) Quartz vein crosscutting carbonate; C) Quartz-actinolite contact; D) Quartz-tourmaline vein cutting through carbonate. 


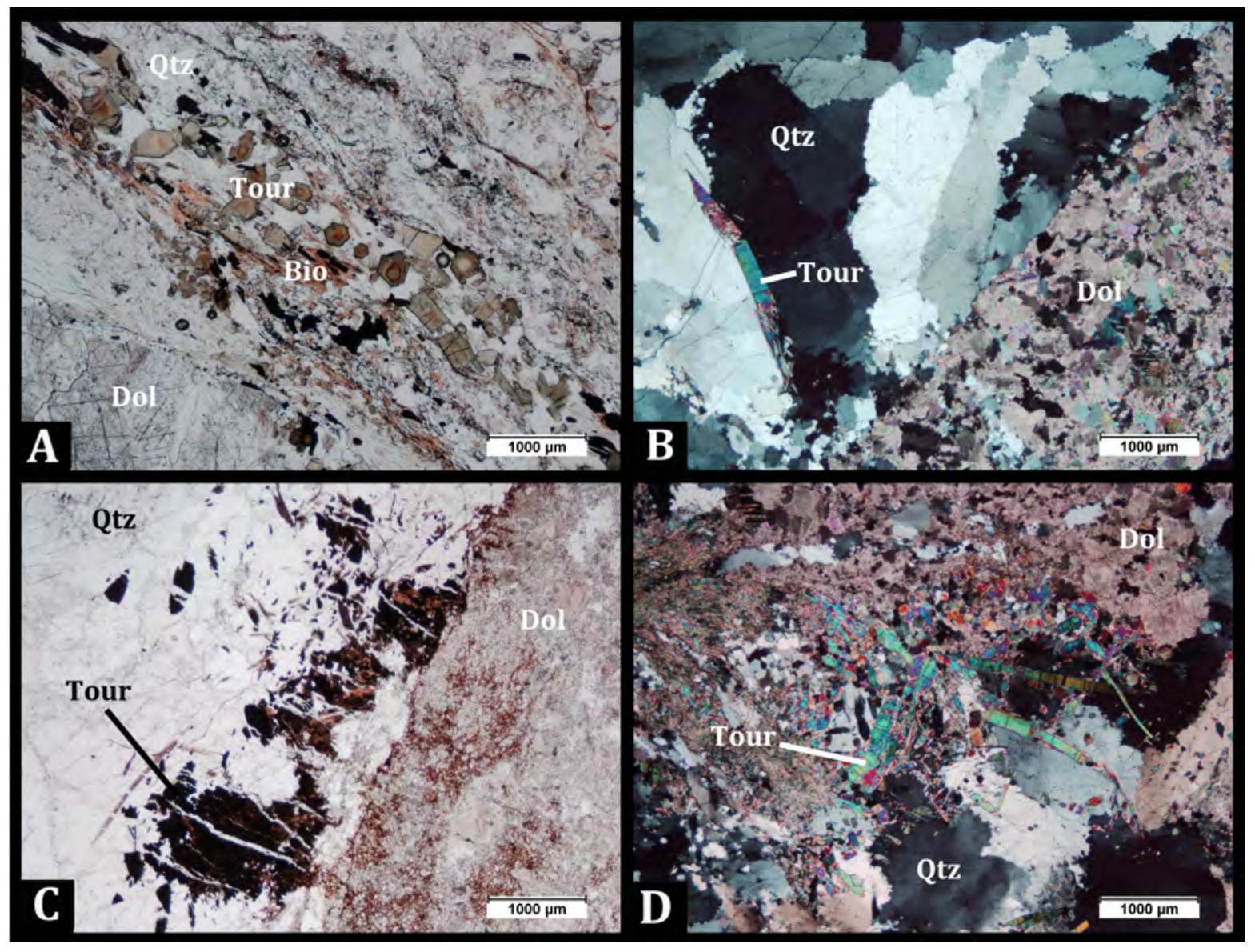

Figure 4.5 - Occurrence of Tourmaline throughout East Bay. (A) tourmaline within quartz from Chevron hole EB-90-12 (PPL), (B) toumaline within quartz veins from the southern Abino outcrops, (C) tourmaline in quartz veins from the large gravel pit outcrop near McMarmac and, (D) tourmaline associating with wallrock from quartz veins at the north Abino outcrops.

\subsection{4 - Albite Veins}

Albite veins occur only at Abino Point and south Abino areas. These veins are thin $(\sim 1-3 \mathrm{~cm})$ and range in colour from white to pink in hand specimen. They cross-cut the early stage dolomitic carbonate veins and occur as distinct veins on their own, but they are occasionally mixed with quartz and quartz-tourmaline veins (Fig. 4.6). 


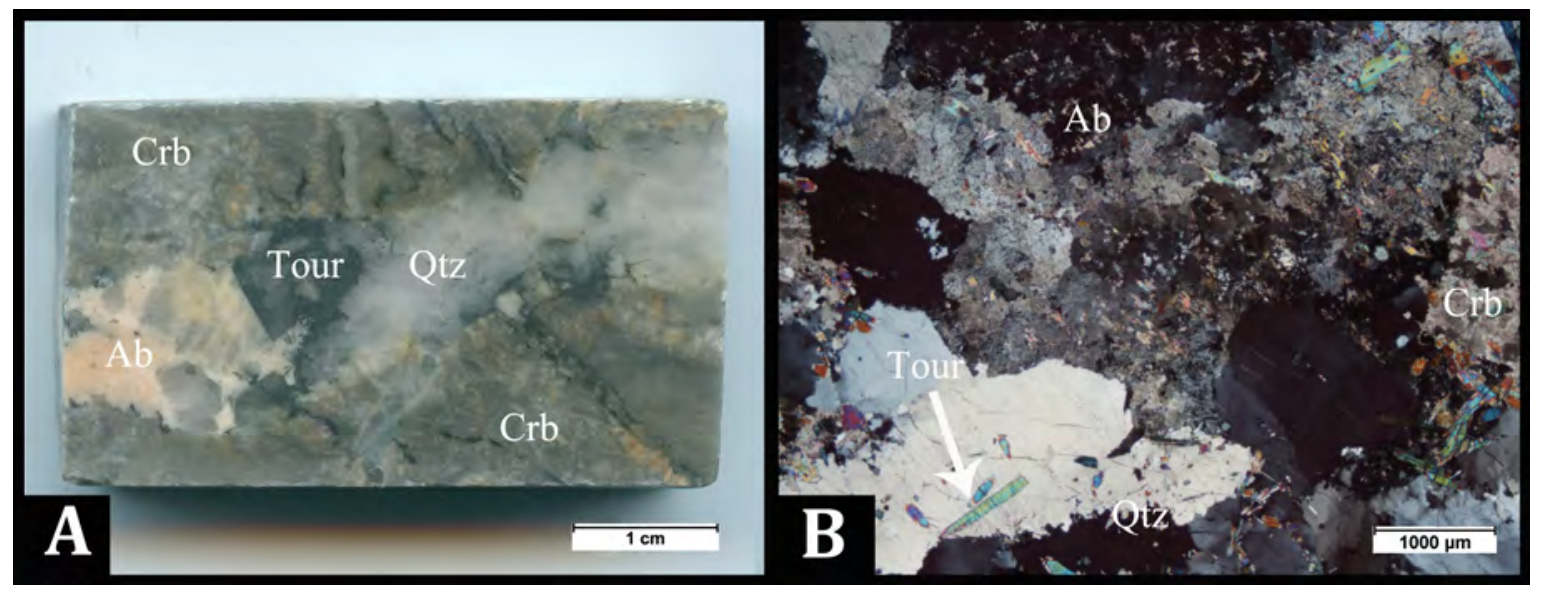

Figure 4.6 - (A) Thick section photo of albite \& quartz-tourmaline veining through carbonate, (B) Photomicrograph of albite \& quartz- tourmaline veining through carbonate

\subsection{5 - Tourmaline-bearing Faults (Black Line)}

The EBT contains 'black line faults' in numerous localities with orientations that are consistent with the Mine Trend and the EBT. These fault zones are characterized by their infilling by quartz (amorphous silica) that produces a sinuous fabric in thin section, yet linear at the outcrop scale. The silica appears devitrified and is very fine-grained (Fig. 4.7). This is accompanied by a significant amount of fine tourmaline (Shorl). These black line faults also contain small quantities of finegrained chlorite and sericite. Black line faults occur late in the history of the RLGB but are themselve crosscut by the small quartz-sericite veinlets (Fig. 4.7b). 


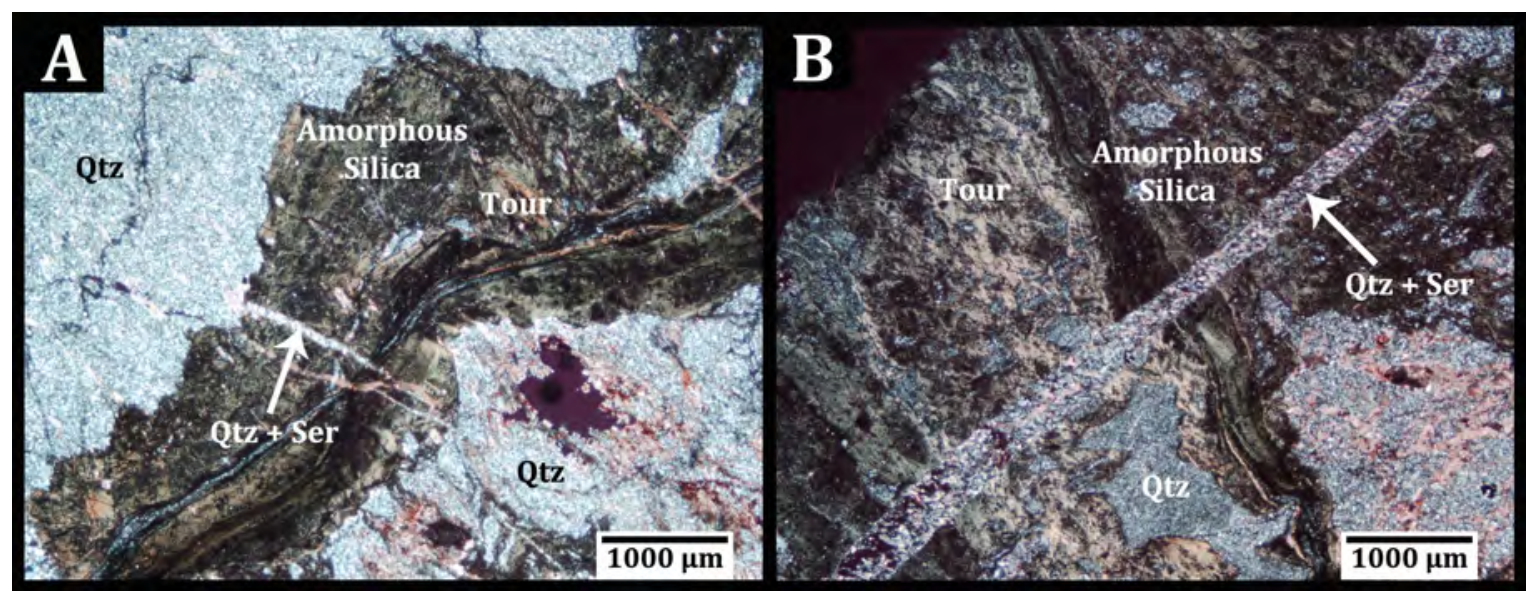

Figure 4.7 - Photomicrographs of 'black line faults' (A) amorphous silica and tourmaline producing a sinuous fabric, (B) amorphous silica with tourmaline crosscut by quartz-sericite veins.

\subsection{6 - Wall Rock Alteration}

Alteration along the EB area is pervasive and the degree to which the host rock is affected depends on the proximity to veins or intrusions. Carbonate alteration is the earliest widespread alteration event in the RLGB, as there is a significant ankerite/dolomite alteration throughout the EB area, as well as most of the eastern RLGB (Fig. 4.8; Parker, 2000). This is associated with the early carbonate veining and alteration prior to $\mathrm{D}_{2}$ deformation, providing pathways for later fluid events. Carbonate mineralogy is dominated by dolomite and ankerite with minimal calcite in the EB area. The timing of different carbonate veins is difficult to determine due to limited exposure and similar mineralogy that reoccurs in several regions of the EB area. Ferroan dolomite alteration is the dominant carbonate alteration throughout the EB area forming the proximal alteration, whereas the calcite is more prevalent along the margins of the RLGB making it the distal alteration, as observed by Parker (2000). 
The rocks of the RLGB were then subsequently silicified, producing extensive quartz replacement. The silicification events occur as either 1) pervasive silicification, or 2) quartz veining associated with gold mineralization \pm sulphides. Silicification is prevalent and is associated with the numerous quartz veining events that have passed through the EBT and the Eastern portion of the RLGB. The degree of silicification is commonly dependent on the host rock with silica flooding rarely occurring in the ultramafic rocks. The quartz veining associated with gold mineralization \pm sulphides is a later alteration, postdating the pervasive silicification. These veins typically occur as fault-filling (crack-seal veins) and openspace filling primary auriferous veins that often associate with sulphide mineralization (arsenopyrite, pyrite). The various alteration zones are generally barren unless the auriferous fluid has silicified them.

Another common alteration style is the chlorite alteration of host rocks. The hydrothermal fluids altered the surrounding volcanic and plutonic rocks adjacent to veins or along permeable pathways, such as pillow selvages. These aluminous alteration zones are associated with the metamorphic aureoles surrounding plutons, are closely linked with the ferroan dolomite alteration zones and appear to have been further affected by the later silicification fluid events. Sericite, biotite, and in rare cases fuschsite (Fig. 4.2C \& 4.2D) occur as alteration minerals in mafic wallrocks adjacent to veins (common around auriferous veining), due to hydration processes. Micaceous alteration halos can become quite wide $(1-5 \mathrm{~m})$ and are more prevalent in the altered ultramafic rocks of the EB, while the mafic wallrocks have narrower haloes. 
A late alteration assemblage consists of narrow tourmaline zones, which are abundant throughout the RLGB and are a distinct feature of the EB area. The tourmaline is typically in narrow faults, fractures, and shear zones or in quartztourmaline veins that range from filling hairline faults to large crack-seal veins. In the EB area the tourmaline veining often crosscuts the larger ferroan dolomite veins. The tourmaline is associated with both auriferous and barren veins.

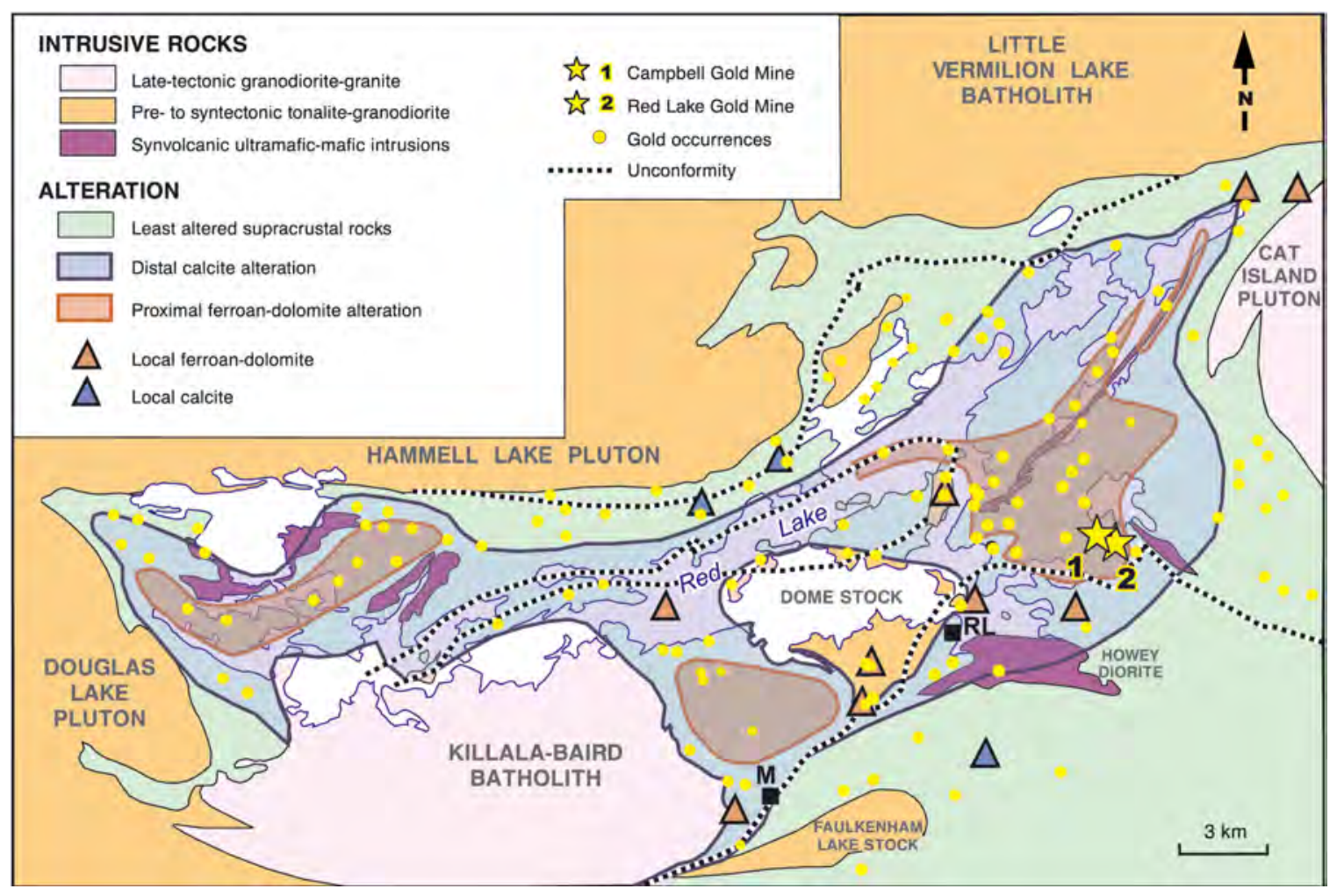

Figure 4.8 - Carbonate alteration zones in the RLGB, also shown are known gold occurrences of the RLGB (after Sanborn-Barrie et al., 2004) 


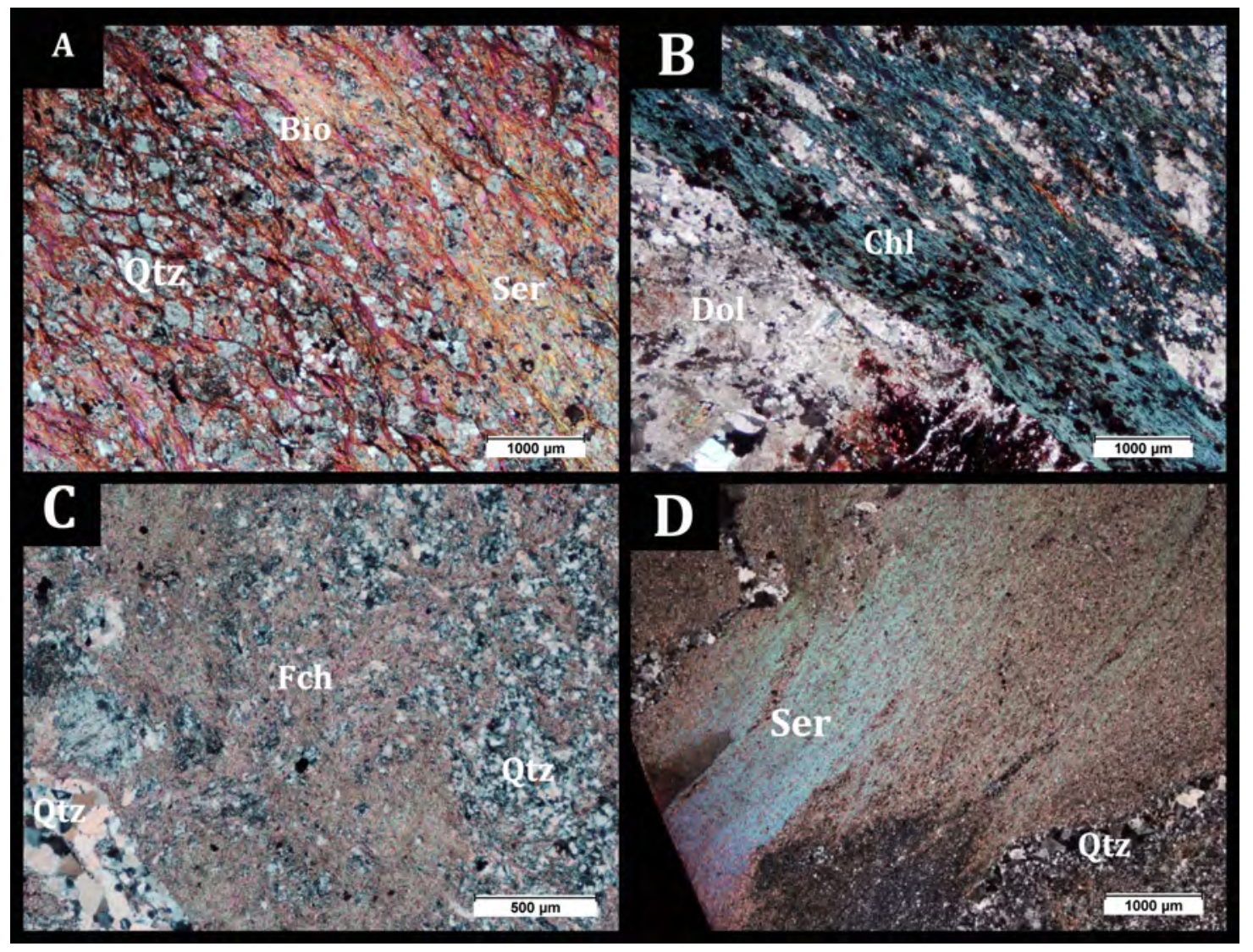

Figure 4.9 - Alteration haloes surrounding vein systems. A) Quartz along the vein margin is brecciated and surrounded by a variety of sericite and biotite; B) Chlorite band defines the contact between wallrock and a dolomite vein; C) Patches of fuchsite are mixed with quartz in a alteration halo; and D) Sericite forms thick alteration layers adjacent to quartz veins.

\section{2 - Microthermometric Data}

Criteria used for identification of primary and secondary inclusions followed the guidelines established by Roedder (1984). Fluid inclusions are generally small (typically 5-25 $\mu \mathrm{m}$ ), with a small proportion of the primary inclusions being slightly larger (25-45 $\mu \mathrm{m})$. Well-defined primary fluid inclusions are found in nearly all samples, typically as small three-dimensional clusters or isolated inclusions within quartz that has not been deformed (Fig. 4.10). Secondary inclusions typically occur along healed fractures producing distinct trails of inclusions (Fig. 4.10). These trails 
may occur as randomly distributed inclusions that are larger and more elongated than typical secondary inclusions along a healed fracture. These secondary inclusion trails commonly form en-echelon producing a series of crosshatched trails. Some of the isolated and random fluid inclusions may be pseudosecondary, but this is difficult to confirm, and were not measured in this study.

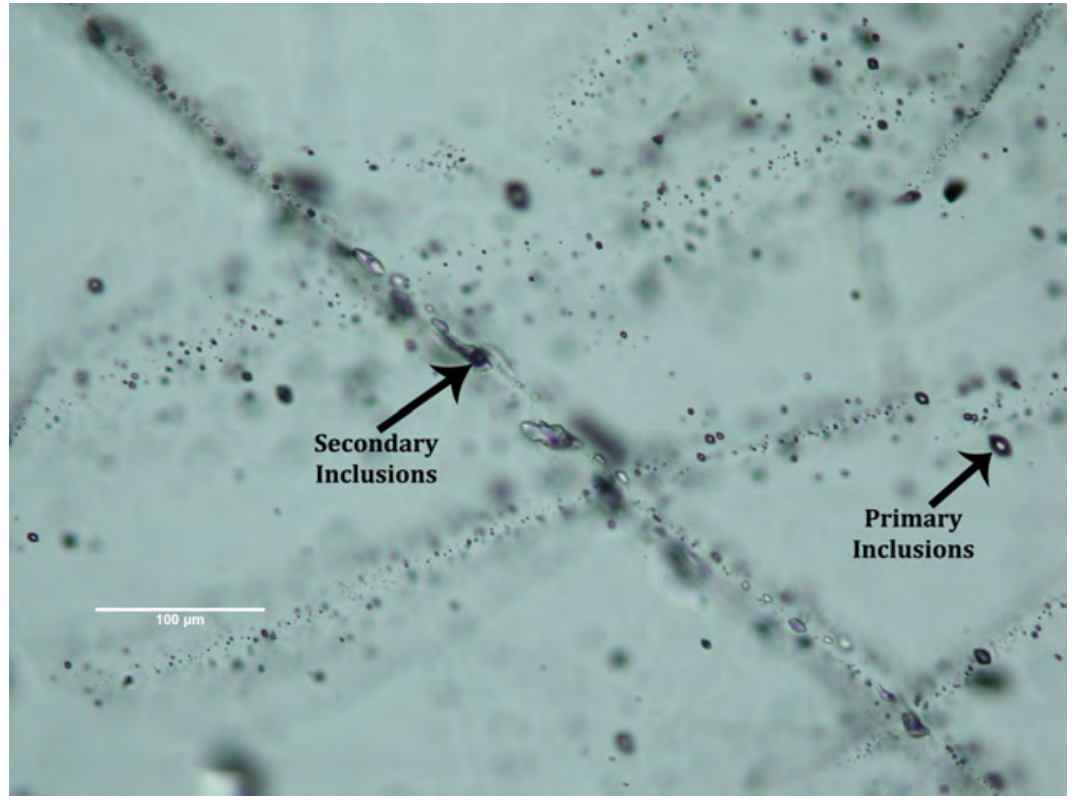

Figure 4.10 - A view of SG10-01 showing primary and secondary fluid inclusions.

Carbonic $\left(\mathrm{CO}_{2}\right.$-rich $)$ inclusions are pervasive in all samples and are the dominant component of the RL fluid system (Tarnocai, 2000; Chi et al, 2002; Chi et al., 2010). Aqueous $\left(\mathrm{H}_{2} \mathrm{O}\right)$ inclusions are much less common but nevertheless, represent an important component in all auriferous samples throughout the EB area.

Inclusions are typically two-phase (liquid + vapor) at room temperature and have a $\mathrm{CO}_{2}$ and/or $\mathrm{H}_{2} \mathrm{O}$ composition, with both primary and secondary inclusions possessing this composition. Three-phase inclusions $\left(\mathrm{H}_{2} \mathrm{O}+\mathrm{CO}_{2}+\right.$ vapor $)$ are also 
present and are generally found in quartz and quartz-tourmaline veins from the southern portion of EB (Marboy/Chevron region). $\mathrm{CO}_{2}$ dominates the fluids in the EB area, although a considerable amount of aqueous inclusions has been identified in localized areas, contrary to previous studies by Chi et al. (2006). The generations of inclusions can be differentiated based on petrography and crosscutting relationships, but due to the distance separating each deposit area along East Bay, veins from each locale will be treated as separate vein system.

Upon melting, the $\mathrm{CO}_{2}$-rich inclusions changed phase close to the temperature of pure $\mathrm{CO}_{2}\left(-55.6^{\circ} \mathrm{C}\right.$ to $\left.-59.7^{\circ} \mathrm{C}\right)$, indicating that the dominant component of the fluid is $\mathrm{CO}_{2}$ with very small quantities of other constituents. The measured freezing point is slightly lower than that of pure $\mathrm{CO} 2$, indicating that there is a small quantity of another gas, such as $\mathrm{CH}_{4}$ or $\mathrm{N}_{2}$. Homogenization temperatures are more variable, ranging from -9.4 to $29.0^{\circ} \mathrm{C}$, which is close to the homogenization temperature of pure $\mathrm{CO}_{2}$. Primary and secondary inclusions each have distinct homogenization temperature ranges.

The data acquired from aqueous inclusions throughout the EB display a wide range of temperatures and salinities from the various deposit areas. Aqueous inclusions are largely secondary inclusions, but can also occur primary aqueous inclusions. Primary aqueous inclusions from all areas throughout East Bay have an average homogenization temperature of $299.1+251.4 /-86.9^{\circ} \mathrm{C}$. The melting temperatures range from $-6.5^{\circ} \mathrm{C}$ to $-22.4^{\circ} \mathrm{C}$ for primary inclusions whereas secondary inclusions form a slightly larger range between $-5.4^{\circ} \mathrm{C}$ to $-24.2^{\circ} \mathrm{C}$. These temperatures correspond to salinities between 6.8 to $25.5 \mathrm{wt} \% \mathrm{NaCl}$ equiv. (Bakker, 
1997; 1998).

\subsection{1 - Tuckers Knob Area}

The outcrop at Tuckers Knob consists of mafic/ultramafic rocks that have been overprinted by early carbonate veins and subsequent quartz-tourmaline veins, which caused extensive chlorite alteration (Fig. 4.11). There are numerous large $(15-40 \mu \mathrm{m})$ primary inclusions and small $(5-15 \mu \mathrm{m})$ secondary inclusions in the quartz-tourmaline veins. These inclusions have variable vapor-liquid ratios (Fig. 4.12) and are generally three-phase $\left(\mathrm{H}_{2} \mathrm{O}+\mathrm{CO}_{2}+\right.$ vapor $)$.

Primary $\mathrm{CO}_{2}$-rich inclusions from the auriferous veins (SG11-171D \& SG11175D2) yield an average melt temperature $\left(\mathrm{T}_{\mathrm{m}}\right)$ of $-58.5 \pm 0.6^{\circ} \mathrm{C}(1 \sigma ; \mathrm{n}=29)$ (Fig. 4.13A $)$ and an average homogenization temperature $\left(T_{h}\right)$ of $13.4 \pm 3.5^{\circ} \mathrm{C}(1 \sigma ; n=29)$ (Fig. 4.13B). Only the weakly mineralized quartz-tourmaline veins were measured from Tuckers Knob and no barren samples were examined. The primary aqueous inclusions have an average $\mathrm{T}_{\mathrm{m}}$ of $-6.5 \pm 3.9^{\circ} \mathrm{C}(1 \sigma ; \mathrm{n}=5)$ (Fig. 4.13C) and an average $\mathrm{T}_{\mathrm{h}}$ of $264.4 \pm 34.6^{\circ} \mathrm{C}(1 \sigma ; \mathrm{n}=5)$ (Fig. 4.13D).

Secondary carbonic fluid inclusions were rare and very small in the auriferous sample and were not measurable, due to their small size. The secondary aqueous inclusions from the auriferous sample have an average $T_{m}$ of $-20.3 \pm 1.9^{\circ} \mathrm{C}$ $(1 \sigma ; n=5)$ (Fig. 4.13A) and a $\mathrm{T}_{\mathrm{h}}$ of $211.1 \pm 8.1^{\circ} \mathrm{C}(1 \sigma ; \mathrm{n}=5)$ (Fig. 4.13B).

Salinity calculated for primary auriferous fluid inclusions from Tuckers Knob are $12.8 \pm 3.5 \mathrm{wt} \% \mathrm{NaCl}(1 \sigma ; \mathrm{n}=11)$ (Fig. 4.13E), whereas secondary auriferous inclusions have a salinity of $17.6 \pm 5.5 \mathrm{wt} \% \mathrm{NaCl}(1 \sigma ; n=8)$. 


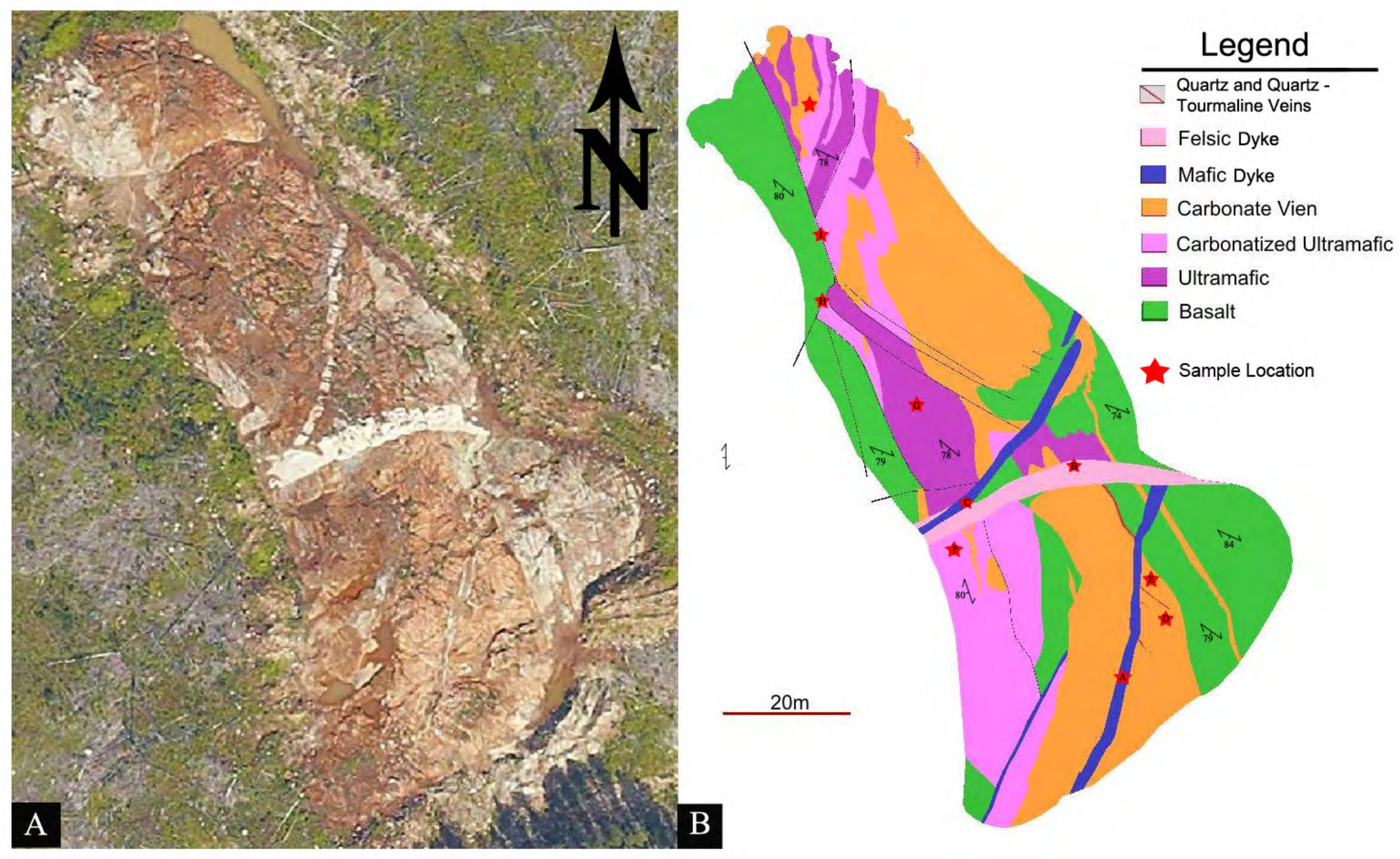

Figure 4.11 - (A) Aerial photograph of the Tuckers Knob outcrop air photo and (B) Geology of Tuckers Knob outcrop with sample locations labeled by red stars (Goldcorp company mapping).

$\stackrel{+}{A}$ 


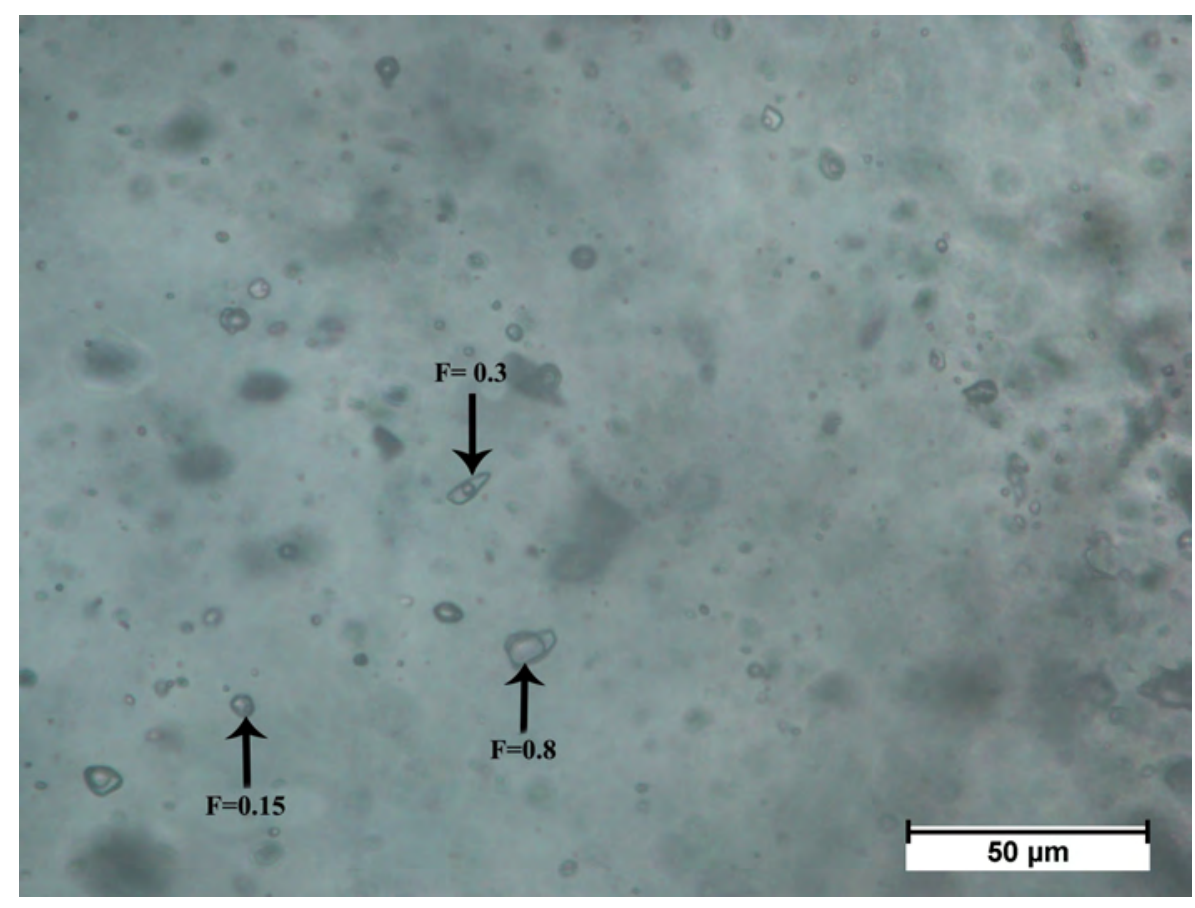

Figure 4.12 - Various primary fluid inclusions with a wide range of vapor-liquid ratios. The F-values represent the ratio of liquid to vapor within a single inclusion at $\sim 16^{\circ} \mathrm{C}$ from quartz veins at Tuckers Knob. 

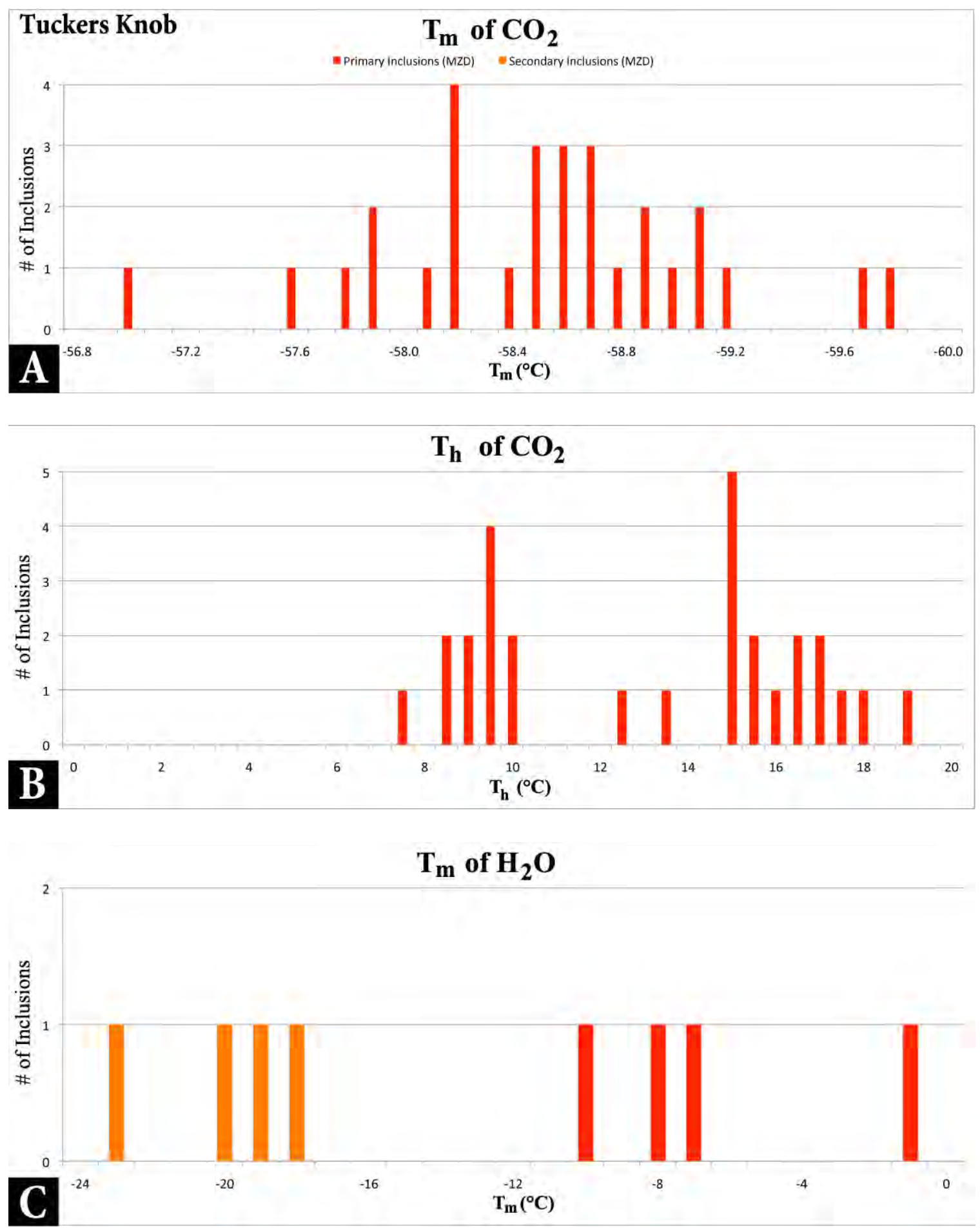

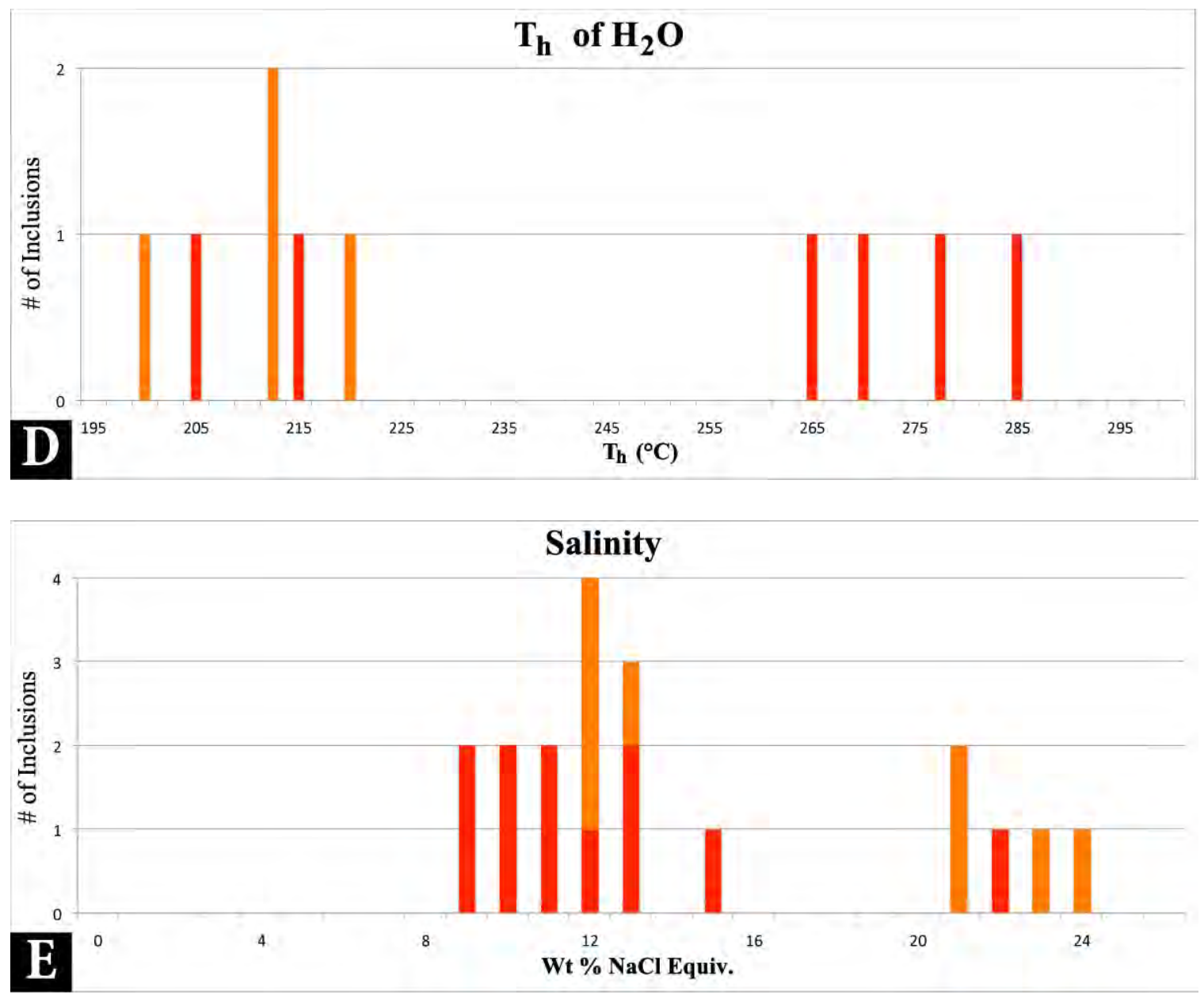

Figure 4.13 - Fluid inclusion data from Tuckers Knob: (A) Melt temperature of $\mathrm{CO}_{2}$ inclusions; (B) Homogenization temperature of $\mathrm{CO}_{2}$ inclusions; (C) Melt temperature of $\mathrm{H}_{2} \mathrm{O}$ inclusions; (D) Homogenization temperature of $\mathrm{H}_{2} \mathrm{O}$ inclusions;

(E) Salinity of aqueous inclusions.

\subsection{2 - Marboy (McMarmac) Area}

The host rock in the McMarmac Mine area is mafic volcanic rocks, komatiitic

flows, and late stage intermediate dykes that crosscut the mafic and komatiitic rocks. Large carbonate veins that contain late, narrow gold mineralized quartz stringers crosscut all three host rocks (Horwood, 1940). The fluid inclusions from quartz veins are generally smaller and more convoluted than those found at the Tuckers Knob area. Three-phase inclusions are present in both barren and 
auriferous veins and constitute a significant portion of the inclusions in these samples. The liquid-vapor ratio from the auriferous sample is uniform $(<10-15 \%$ variation of ratio between inclusions). In contrast, the inclusions in the barren sample give ratios that varies by up to $50 \%$ in vapor content (Fig. 4.14). Primary fluid inclusions are moderately sized $(\sim 10-30 \mu \mathrm{m})$ and dominate the auriferous sample.

The primary $\mathrm{CO}_{2}$-rich inclusions from the auriferous veins (sample MB89106) have an average $T_{m}$ of $-57.5 \pm 0.8^{\circ} \mathrm{C}(1 \sigma ; n=14)$ (Fig. 4.15A) and a $T_{h}$ of $11.3 \pm$ $6.4^{\circ} \mathrm{C}(1 \sigma ; \mathrm{n}=14)$ (Fig. 4.15B), whereas the barren sample (MB10034-03) has an average $T_{m}$ of $-57.2 \pm 0.7^{\circ} \mathrm{C}(1 \sigma ; n=14)$ and $a T_{h}$ of $13.3 \pm 6.1^{\circ} \mathrm{C}(1 \sigma ; n=14)$ from primary inclusions. Primary aqueous inclusions from the auriferous sample yield an average $\mathrm{T}_{\mathrm{m}}$ of $-15.6 \pm 3.3^{\circ} \mathrm{C}(1 \sigma ; \mathrm{n}=9)$ (Fig. $\left.4.15 \mathrm{C}\right)$ and a $\mathrm{T}_{\mathrm{h}}$ of $314.7 \pm 33.3^{\circ} \mathrm{C}(1 \sigma$; $n=9)$ (Fig. 4.15D), whereas the barren sample gives an average $T_{m}$ of $-14.5 \pm 0^{\circ} \mathrm{C}(1 \sigma$; $\mathrm{n}=1)$ and $\mathrm{a} \mathrm{T}_{\mathrm{h}}$ of $232.7 \pm 0^{\circ} \mathrm{C}(1 \sigma ; \mathrm{n}=1)$.

Secondary fluid inclusions were rare in the auriferous sample and were not measurable, due to their small size. The secondary $\mathrm{CO}_{2}$-rich inclusions from the barren sample have an average $T_{m}$ of $-57.4 \pm 0.6^{\circ} \mathrm{C}(1 \sigma ; n=6)$ and $a T_{h}$ of $7.8 \pm 3.6^{\circ} \mathrm{C}$ $(1 \sigma ; n=6)$. The secondary aqueous inclusions yield a $T_{m}$ of $-9.8 \pm 2.2^{\circ} \mathrm{C}(1 \sigma ; n=6)$ and a $\mathrm{T}_{\mathrm{h}}$ of $249.7 \pm 27.2^{\circ} \mathrm{C}(1 \sigma ; \mathrm{n}=6)$.

Salinity calculated for primary auriferous fluid inclusions from Marboy are $19.0 \pm 2.7 \mathrm{wt} \% \mathrm{NaCl}(1 \sigma ; \mathrm{n}=9$ ) (Fig. 4.15E), whereas primary fluid inclusions from the barren sample contain $13.4 \mathrm{wt} \% \mathrm{NaCl}(1 \sigma ; \mathrm{n}=1)$. Secondary barren inclusions have a salinity of $13.5 \pm 2.2 \mathrm{wt} \% \mathrm{NaCl}(1 \sigma ; \mathrm{n}=6$ ) (Fig. 4.15E). 


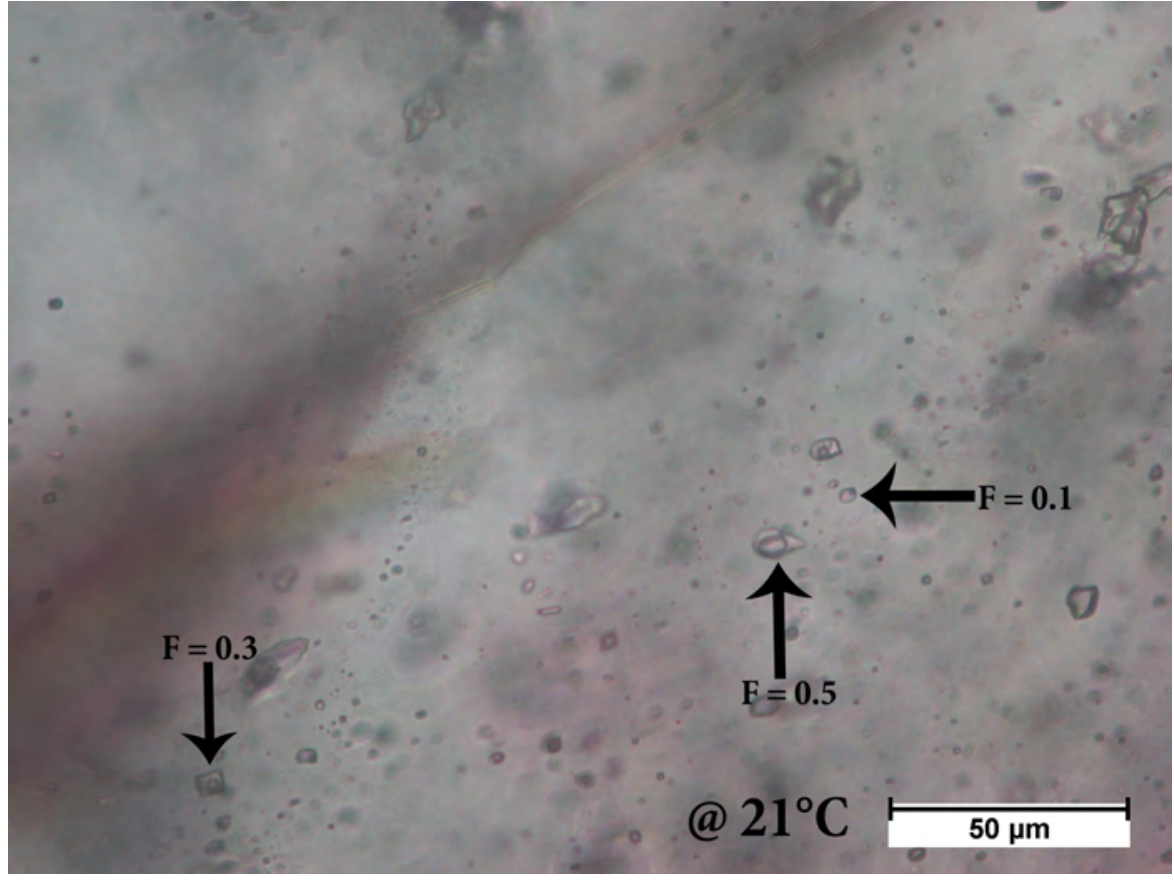

Figure 4.14 - Photomicrograph of sample MB10034 from the Marboy (McMarmac Mine) area. A significant variation in liquid-vapor ratios is shown from a single fluid inclusion assemblage, based on the bubble that is present. The F-values represents the ratio of liquid to vapor within an assemblage of inclusions at $\sim 21^{\circ} \mathrm{C}$ from quartz veins at Marboy. 

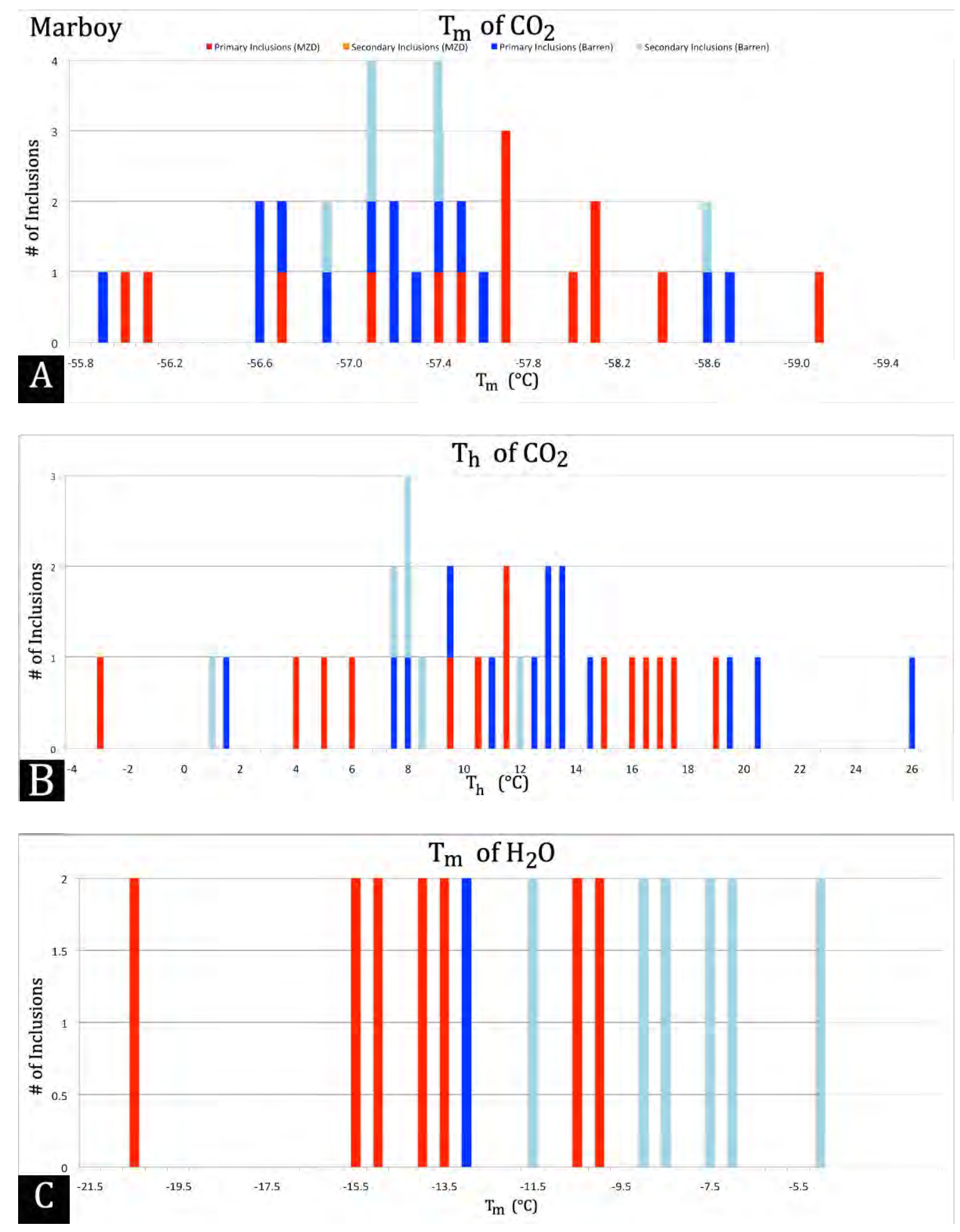

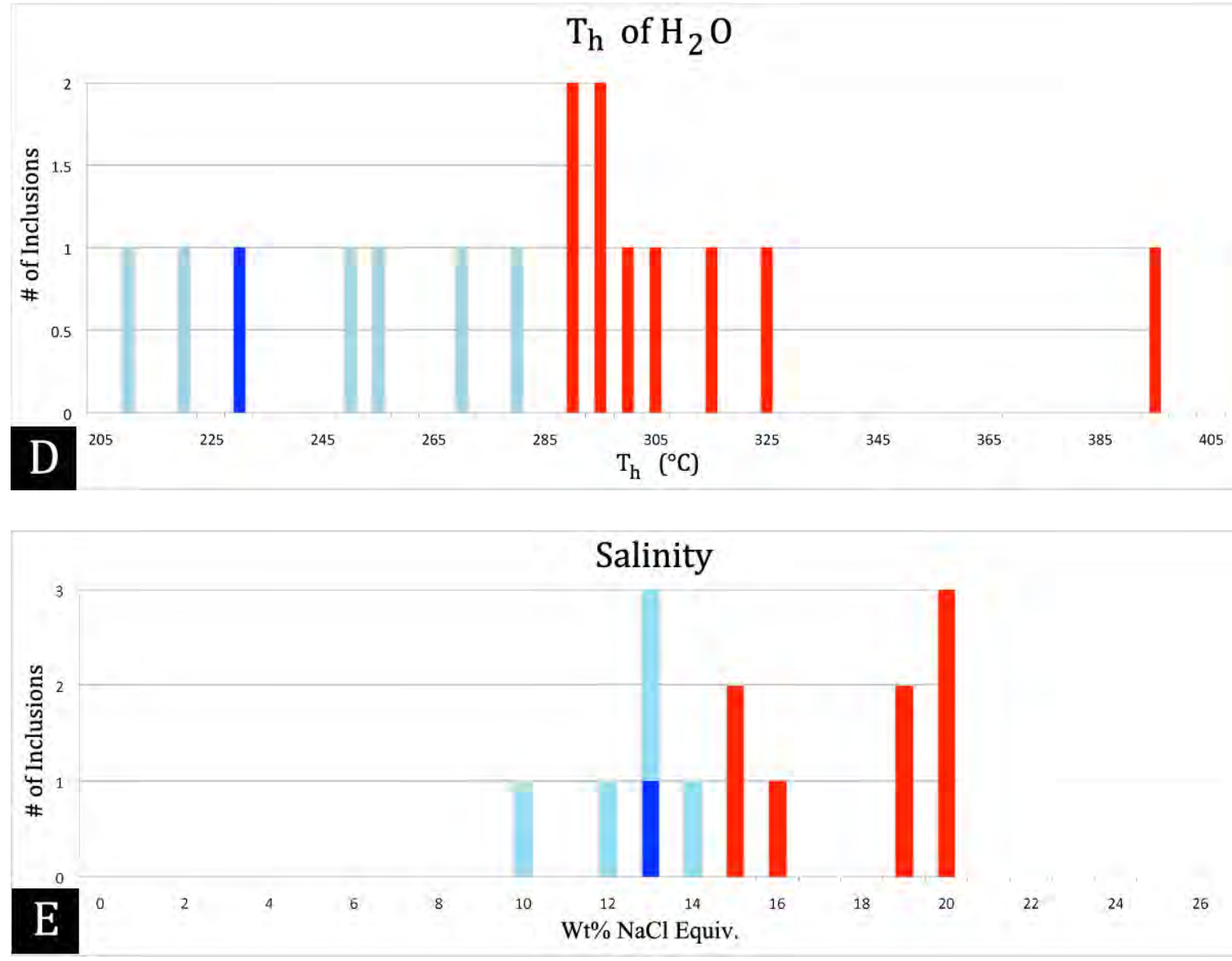

Figure 4.15 - Fluid inclusion data from the McMarmac area: (A) Melt temperature of $\mathrm{CO}_{2}$ inclusions; (B) Homogenization temperature of $\mathrm{CO}_{2}$ inclusions; (C) Melt temperature of $\mathrm{H}_{2} \mathrm{O}$ inclusions; (D) Homogenization temperature of $\mathrm{H}_{2} \mathrm{O}$ inclusions;

(E) Salinity of aqueous inclusions.

\subsection{3 - Chevron Area}

The Chevron deposit is identified by the intense silicification of mafic dykes that have intruded into the disjointed shear zone of the EBDZ, which were extremely biotite-rich and partially altered to chlorite prior to the intrusion of numerous ultramafic dykes. These mafic dykes have been faulted and offset, producing very discontinuous units (Sannes \& Dehn, 2000). Closely spaced, en-echelon quartz veins give the best gold-grades $(0.20$ to $0.65 \mathrm{oz} / \mathrm{t})$ and are associated with intense silicification of the host-rocks. Although the dominant mineral in these veins is 
quartz, minor amounts of carbonate are also present. Fluid inclusion morphology and composition from Chevron quartz veins are similar to those reported from McMarmac. Primary fluid inclusions are $\sim 10-40 \mu \mathrm{m}$ across, while secondary inclusions are smaller $(\sim 5-20 \mu \mathrm{m})$. Three phase inclusions dominate over other fluid inclusion types, and have liquid-vapor ratios that are similar, with this type of inclusions occurring in both auriferous and barren samples.

Primary, $\mathrm{CO}_{2}$-rich inclusions from the auriferous sample (EB9017-01) have an average $\mathrm{T}_{\mathrm{m}}$ value of $-56.6 \pm 0.3^{\circ} \mathrm{C}(1 \sigma ; \mathrm{n}=11)($ Fig. $4.16 \mathrm{~A})$ and $\mathrm{a} \mathrm{T}_{\mathrm{h}}$ of $11.4 \pm 6.9^{\circ} \mathrm{C}$

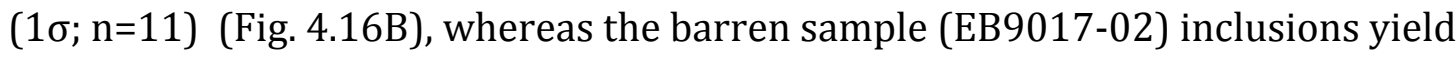
$\mathrm{T}_{\mathrm{m}}$ values of $-55.9 \pm 0.3^{\circ} \mathrm{C}(1 \sigma ; \mathrm{n}=14)$ and have $\mathrm{a} \mathrm{T}_{\mathrm{h}}$ of $8.5 \pm 6.8^{\circ} \mathrm{C}(1 \sigma ; \mathrm{n}=14)$. Primary aqueous inclusions from the auriferous sample have an average $\mathrm{T}_{\mathrm{m}}$ value of $-14.8 \pm 5.2^{\circ} \mathrm{C}(1 \sigma ; \mathrm{n}=10)$ and $\mathrm{a} \mathrm{T}_{\mathrm{h}}$ of $265.6 \pm 53.3^{\circ} \mathrm{C}(1 \sigma ; \mathrm{n}=10)$, whereas the primary aqueous inclusions from the barren sample have an average $\mathrm{T}_{\mathrm{m}}$ of $-12.3 \pm 2.3^{\circ} \mathrm{C}(1 \sigma$; $\mathrm{n}=12)$ and $\mathrm{a} \mathrm{T}_{\mathrm{h}}$ of $260.8 \pm 51.1^{\circ} \mathrm{C}(1 \sigma ; \mathrm{n}=12)$.

Secondary fluid inclusions were rare in the auriferous sample and only one carbonic inclusion could be dependably measured, due to their small size. The secondary $\mathrm{CO}_{2}$-rich inclusions from the auriferous sample have an average $\mathrm{T}_{\mathrm{m}}$ of $56.6 \pm 0.0^{\circ} \mathrm{C}(1 \sigma ; \mathrm{n}=1)$ and $\mathrm{a} \mathrm{T}_{\mathrm{h}}$ of $7.9 \pm 0.0^{\circ} \mathrm{C}(1 \sigma ; \mathrm{n}=1)$, whereas the barren sample gives a $\mathrm{T}_{\mathrm{m}}$ of $-58.4 \pm 1.0^{\circ} \mathrm{C}(1 \sigma ; \mathrm{n}=7)$ and a $\mathrm{T}_{\mathrm{h}}$ of $5.6 \pm 3.6^{\circ} \mathrm{C}(1 \sigma ; \mathrm{n}=7)$. The secondary aqueous inclusions from the auriferous sample yield a $\mathrm{T}_{\mathrm{m}}$ of $-22.7 \pm 1.1^{\circ} \mathrm{C}(1 \sigma ; \mathrm{n}=5)$ and a $T_{h}$ of $180.2 \pm 16.7^{\circ} \mathrm{C}(1 \sigma ; n=5)$, whereas the barren sample yields a $T_{m}$ of -12.6 $\pm 0.0^{\circ} \mathrm{C}(1 \sigma ; \mathrm{n}=1)$ and $\mathrm{a} \mathrm{T}_{\mathrm{h}}$ of $173.4 \pm 0.0^{\circ} \mathrm{C}(1 \sigma ; \mathrm{n}=1)$. Secondary inclusions demonstrate a lower temperature for both $\mathrm{T}_{\mathrm{m}}$ (Fig. 4.16C) and $\mathrm{T}_{\mathrm{h}}$ (Fig. 4.16D) in 
aqueous inclusions.

Average salinity calculated from primary auriferous inclusions is $18.1 \pm 4.8$ wt.\% $\mathrm{NaCl}(1 \sigma ; \mathrm{n}=9)$ and salinity from primary barren inclusions is $16.1 \pm 2.2 \mathrm{wt} . \%$ $\operatorname{NaCl}(1 \sigma ; n=12)$. Average salinity from secondary auriferous inclusions is $24.3 \pm 0.9$ wt. $\% \mathrm{NaCl}(1 \sigma ; \mathrm{n}=5)$, whereas barren secondary inclusions is $12.9 \pm 2.3 \mathrm{wt} . \% \mathrm{NaCl}$ $(1 \sigma ; n=4)$ (Fig. 4.16E).
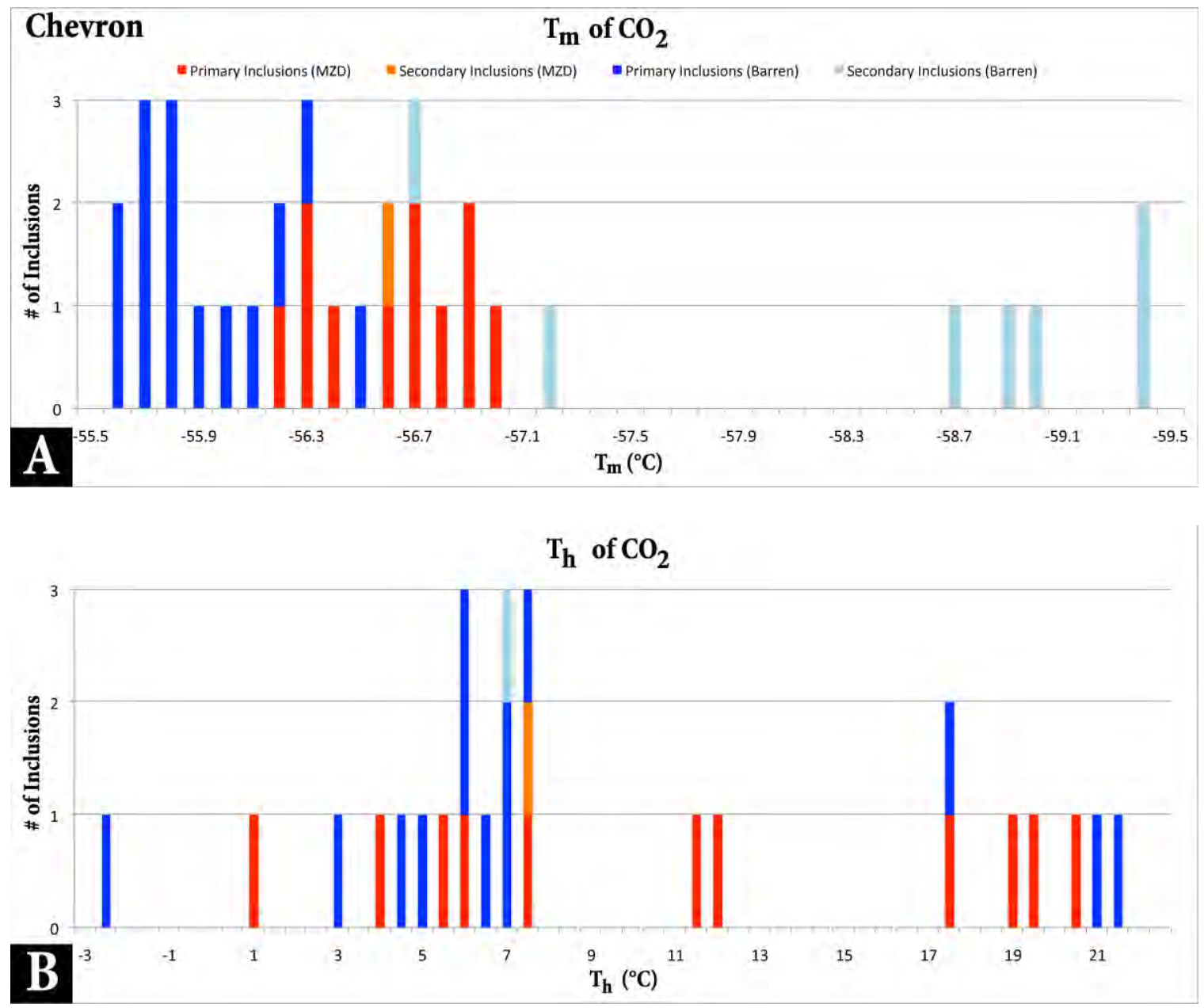

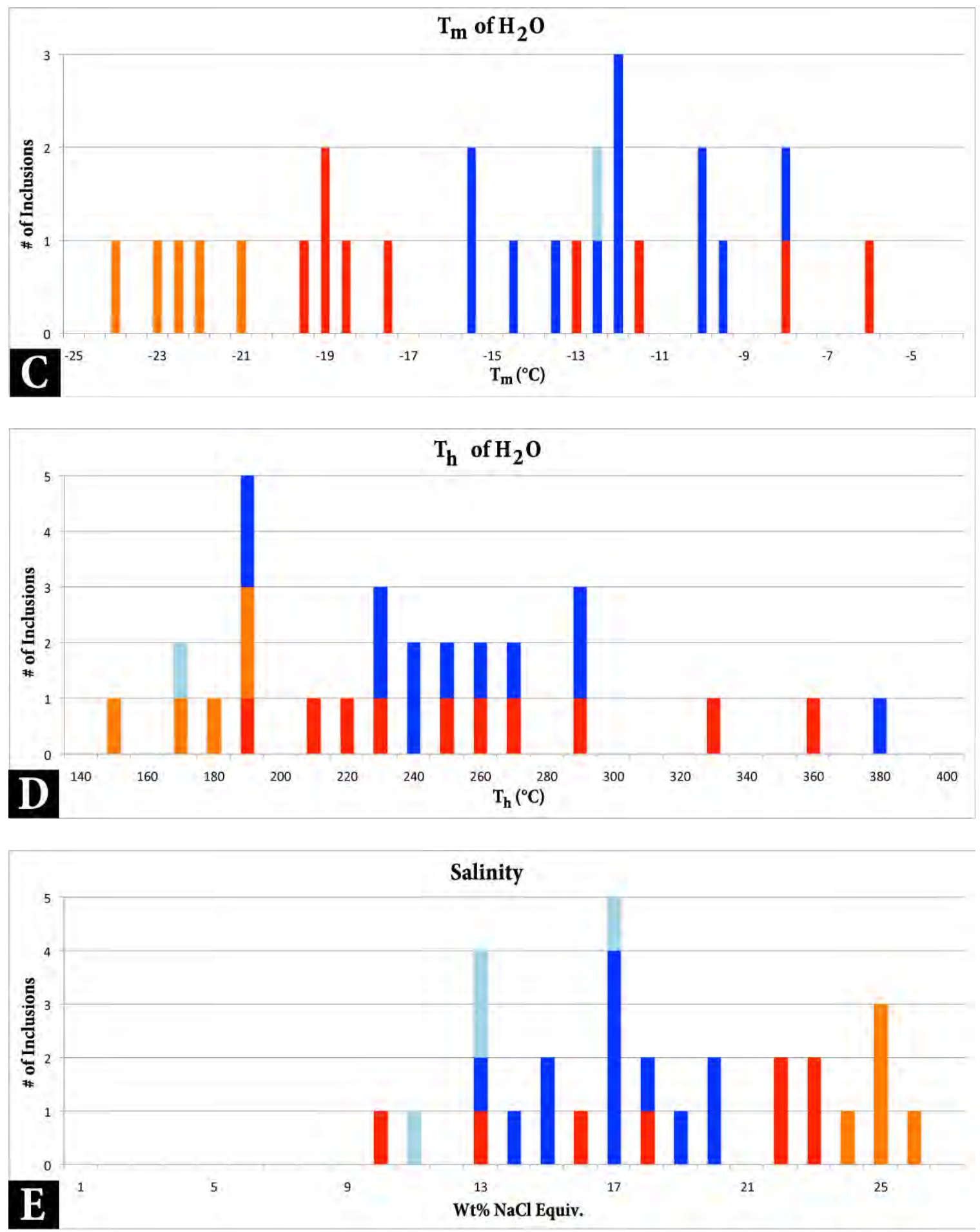

Figure 4.16 - Fluid inclusion data from the Chevron Zone: (A) Melt temperature of $\mathrm{CO}_{2}$ inclusions; (B) Homogenization temperature of $\mathrm{CO}_{2}$ inclusions; (C) Melt temperature of $\mathrm{H}_{2} \mathrm{O}$ inclusions; (D) Homogenization temperature of $\mathrm{H}_{2} \mathrm{O}$ inclusions;

(E) Salinity of aqueous inclusions. 


\subsection{4 - Abino Area}

Intermixed glassy and milky-quartz veins are the dominant auriferous vein type in the Abino area with lesser massive quartz and carbonate veins. Fluid inclusions were best observed in the glassy-quartz veins and are typically small $(\sim 5-25 \mu \mathrm{m})$, predominantly secondary in nature with rare primary inclusions that have been preserved. Milky-quartz was not used for the fluid inclusion study, due to the muddled arrangement of several generations of inclusions. Aqueous and $\mathrm{CO}_{2}-$ rich fluid inclusions with relatively constant liquid-vapor ratios dominate over the three-phase inclusions at Abino.

The $\mathrm{CO}_{2}$-rich primary inclusions from the auriferous sample (ABU35-01) yield average $\mathrm{T}_{\mathrm{m}}$ of $-57.2 \pm 0.7^{\circ} \mathrm{C}(1 \sigma ; \mathrm{n}=11)$ (Fig. $\left.4.17 \mathrm{~A}\right)$ and a $\mathrm{T}_{\mathrm{h}}$ of $20.2 \pm 3.2^{\circ} \mathrm{C}(1 \sigma$; $n=11$ ) (Fig. 4.17B), whereas the barren sample (ABU51-01) has an average $T_{m}$ of $58.3 \pm 0.9^{\circ} \mathrm{C}(1 \sigma ; \mathrm{n}=5)$ and give $\mathrm{T}_{\mathrm{h}}$ of $12.2 \pm 7.3^{\circ} \mathrm{C}(1 \sigma ; \mathrm{n}=5)$. The primary aqueous inclusions from the auriferous sample have an average $T_{m}$ of $-15.4 \pm 6.2^{\circ} \mathrm{C}(1 \sigma ; n=9)$ (Fig. 4.17C) and a $\mathrm{T}_{\mathrm{h}}$ of $270.4 \pm 44.9^{\circ} \mathrm{C}(1 \sigma ; \mathrm{n}=9)$ (Fig. 4.17D), whereas the barren sample has an average $\mathrm{T}_{\mathrm{m}}$ of $-12.5 \pm 0.8^{\circ} \mathrm{C}(1 \sigma ; \mathrm{n}=6)$ and a $\mathrm{T}_{\mathrm{h}}$ of $289.4 \pm 29.6^{\circ} \mathrm{C}(1 \sigma$; $n=6)$.

Secondary fluid inclusions are rare in the auriferous sample and only one carbonic inclusion could be dependably measured, due to their small size. The secondary $\mathrm{CO}_{2}$-rich inclusions from the auriferous sample have an average $\mathrm{T}_{\mathrm{m}}$ of $56.6 \pm 0.0^{\circ} \mathrm{C}(1 \sigma ; \mathrm{n}=1)$ and $\mathrm{a} \mathrm{T}_{\mathrm{h}}$ of $7.9 \pm 0.0^{\circ} \mathrm{C}(1 \sigma ; \mathrm{n}=1)$, whereas the barren sample gives a $T_{m}$ of $-58.4 \pm 1.0^{\circ} \mathrm{C}(1 \sigma ; n=7)$ and a $T_{h}$ of $5.6 \pm 3.6^{\circ} \mathrm{C}(1 \sigma ; n=7)$. The secondary aqueous inclusions from the auriferous sample yield a $\mathrm{T}_{\mathrm{m}}$ of $-22.7 \pm 1.1^{\circ} \mathrm{C}(1 \sigma ; \mathrm{n}=5)$ 
and a $\mathrm{T}_{\mathrm{h}}$ of $180.2 \pm 16.7^{\circ} \mathrm{C}(1 \sigma ; \mathrm{n}=5)$, whereas the barren sample yields a $\mathrm{T}_{\mathrm{m}}$ of -12.6 $\pm 0.0^{\circ} \mathrm{C}(1 \sigma ; \mathrm{n}=1)$ and $\mathrm{a} \mathrm{T}_{\mathrm{h}}$ of $173.4 \pm 0.0^{\circ} \mathrm{C}(1 \sigma ; \mathrm{n}=1)$. Secondary inclusions give a lower temperature for both $\mathrm{T}_{\mathrm{m}}$ (Fig. 4.17C) and $\mathrm{T}_{\mathrm{h}}$ (Fig. 4.17D) in aqueous inclusions.

The average salinity calculated from primary auriferous inclusions is $17.9 \pm$ $6.0 \mathrm{wt} . \% \mathrm{NaCl}(1 \sigma ; \mathrm{n}=9)$ and salinity from primary barren inclusions is $16.2 \pm 1.0$ wt.\% $\mathrm{NaCl}(1 \sigma ; \mathrm{n}=6)$. The average salinity from secondary auriferous inclusions is $10.4 \pm 0.0$ wt. $\% \mathrm{NaCl}(1 \sigma ; \mathrm{n}=1)$, whereas barren secondary inclusions have a salinity of $18.5 \pm 1.3$ wt.\% $\mathrm{NaCl}(1 \sigma ; n=2)$ (Fig. 4.17E).
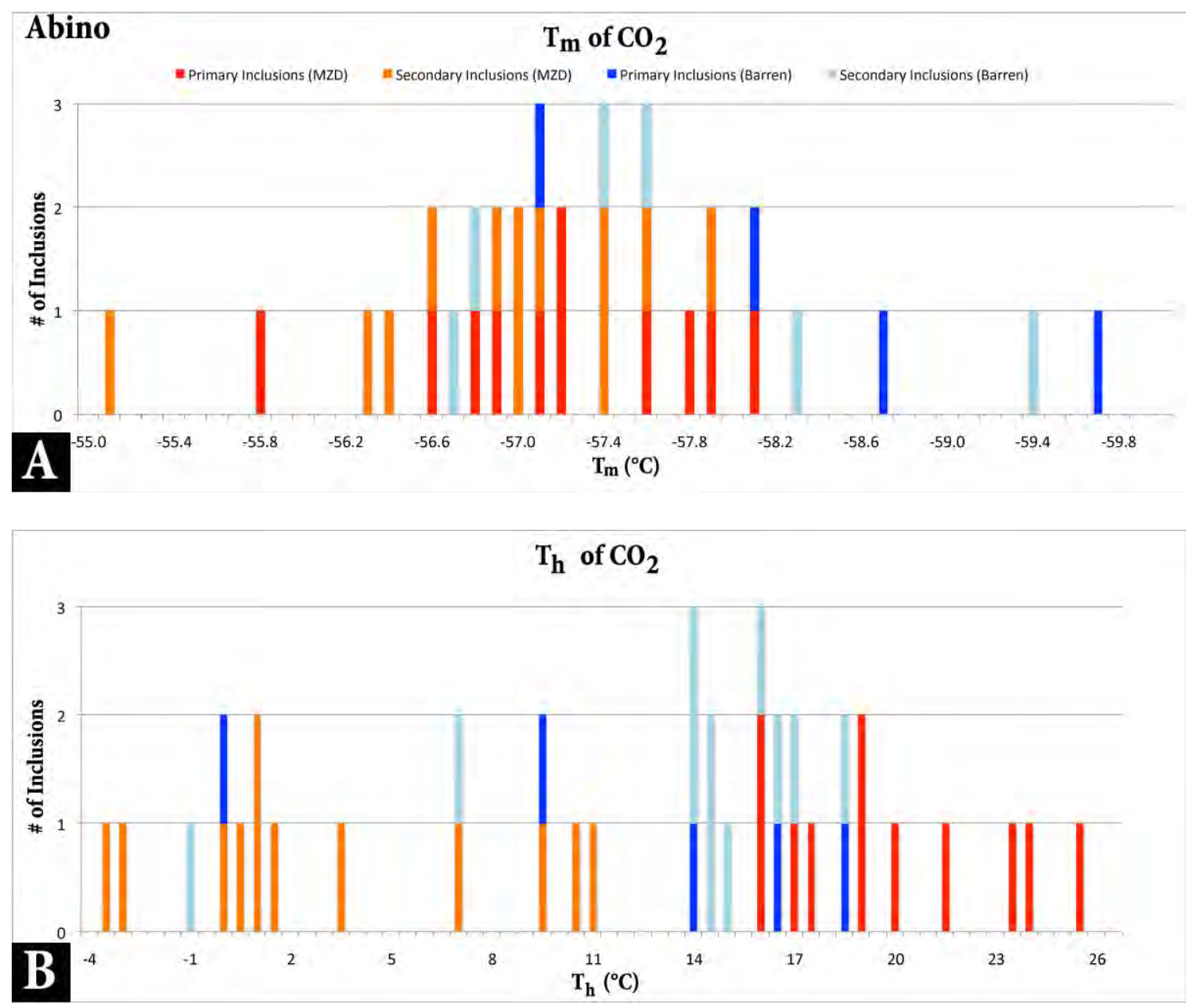

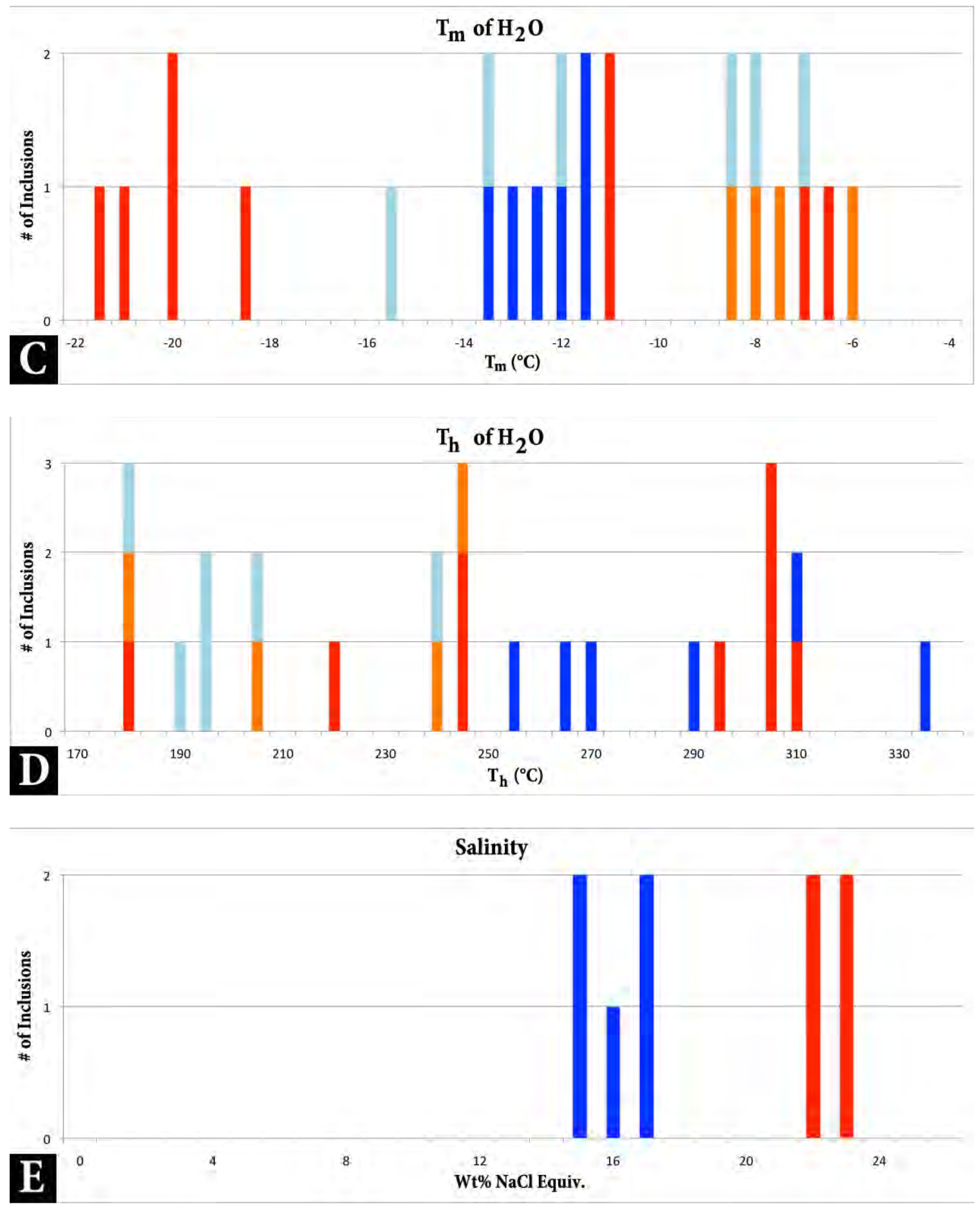

Figure 4.17 - Fluid inclusion data from the Abino area: (A) Melt temperature of $\mathrm{CO}_{2}$ inclusions; (B) Homogenization temperature of $\mathrm{CO}_{2}$ inclusions; (C) Melt temperature of $\mathrm{H}_{2} \mathrm{O}$ inclusions; (D) Homogenization temperature of $\mathrm{H}_{2} \mathrm{O}$ inclusions;

(E) Salinity of aqueous inclusions. 


\subsection{5 - McFinley Area - Duchesne GAZ Zone}

Quartz veins from the McFinley area are hosted in talc-bearing ultramafic rocks (Dumoulin, 2009). Veins are mainly composed of quartz and vary in width from $1 \mathrm{~cm}$ to $0.5 \mathrm{~m}$ and are commonly associated with silicified (bleached) zones of the ultramafic host rocks. Carbonic fluid inclusions dominate the auriferous and barren veins at Duchesne, making it difficult to identify any aqueous inclusions. The carbonic inclusions occur as small $(<25 \mu \mathrm{m})$ primary and secondary inclusions with liquid-vapor ratios that vary by greater than $15 \%$ between inclusions.

The primary $\mathrm{CO}_{2}$-rich inclusions from the auriferous sample (EB10048-03) have an average $\mathrm{T}_{\mathrm{m}}$ of $-58.0 \pm 0.7^{\circ} \mathrm{C}(1 \sigma ; \mathrm{n}=8)$ (Fig. $\left.4.18 \mathrm{~A}\right)$ and a $\mathrm{T}_{\mathrm{h}}$ of $11.8 \pm 4.5^{\circ} \mathrm{C}$ $(1 \sigma ; n=8)$ (Fig. 4.18B), whereas the barren sample (EB10048-02) yields an average $\mathrm{T}_{\mathrm{m}}$ of $-56.2 \pm 0.3^{\circ} \mathrm{C}(1 \sigma ; \mathrm{n}=12)$ and $\mathrm{T}_{\mathrm{h}}$ of $3.3 \pm 7.6^{\circ} \mathrm{C}(1 \sigma ; \mathrm{n}=12)$. The few primary aqueous inclusions from the auriferous sample have an average $\mathrm{T}_{\mathrm{m}}$ of $-9.4 \pm 3.6^{\circ} \mathrm{C}$ $(1 \sigma ; \mathrm{n}=3)$ (Fig. 4.18C) and a $\mathrm{T}_{\mathrm{h}}$ of $442.0 \pm 108.6^{\circ} \mathrm{C}(1 \sigma ; \mathrm{n}=3)$ (Fig. 4.18D), whereas the barren sample was devoid of aqueous inclusions.

Secondary $\mathrm{CO}_{2}$-rich inclusions from the auriferous sample have an average $\mathrm{T}_{\mathrm{m}}$ of $-57.1 \pm 0.9^{\circ} \mathrm{C}(1 \sigma ; \mathrm{n}=5)$ and $\mathrm{a} \mathrm{T}_{\mathrm{h}}$ of $14.3 \pm 3.1^{\circ} \mathrm{C}(1 \sigma ; \mathrm{n}=5)$, whereas the barren sample gives a $\mathrm{T}_{\mathrm{m}}$ of $-56.7 \pm 0.3^{\circ} \mathrm{C}(1 \sigma ; \mathrm{n}=6)$ and a $\mathrm{T}_{\mathrm{h}}$ of $4.7 \pm 2.6^{\circ} \mathrm{C}(1 \sigma ; \mathrm{n}=6)$. The secondary aqueous inclusions from the auriferous sample yield a $\mathrm{T}_{\mathrm{m}}$ of $-14.5 \pm 0.0^{\circ} \mathrm{C}$ $(1 \sigma ; \mathrm{n}=1)$ and $\mathrm{a} \mathrm{T}_{\mathrm{h}}$ of $349.8 \pm 0.0^{\circ} \mathrm{C}(1 \sigma ; \mathrm{n}=1)$, whereas secondary inclusions were absent from the barren sample.

The average salinity calculated from primary auriferous inclusions is $12.9 \pm$ $4.3 \mathrm{wt} . \% \mathrm{NaCl}(1 \sigma ; \mathrm{n}=3)$ and salinity from secondary auriferous inclusions is $18.2 \pm$ 
0.0 wt. $\% \mathrm{NaCl}(1 \sigma ; \mathrm{n}=1)$ (Fig. 4.18E). Barren samples were devoid of aqueous fluid inclusions.
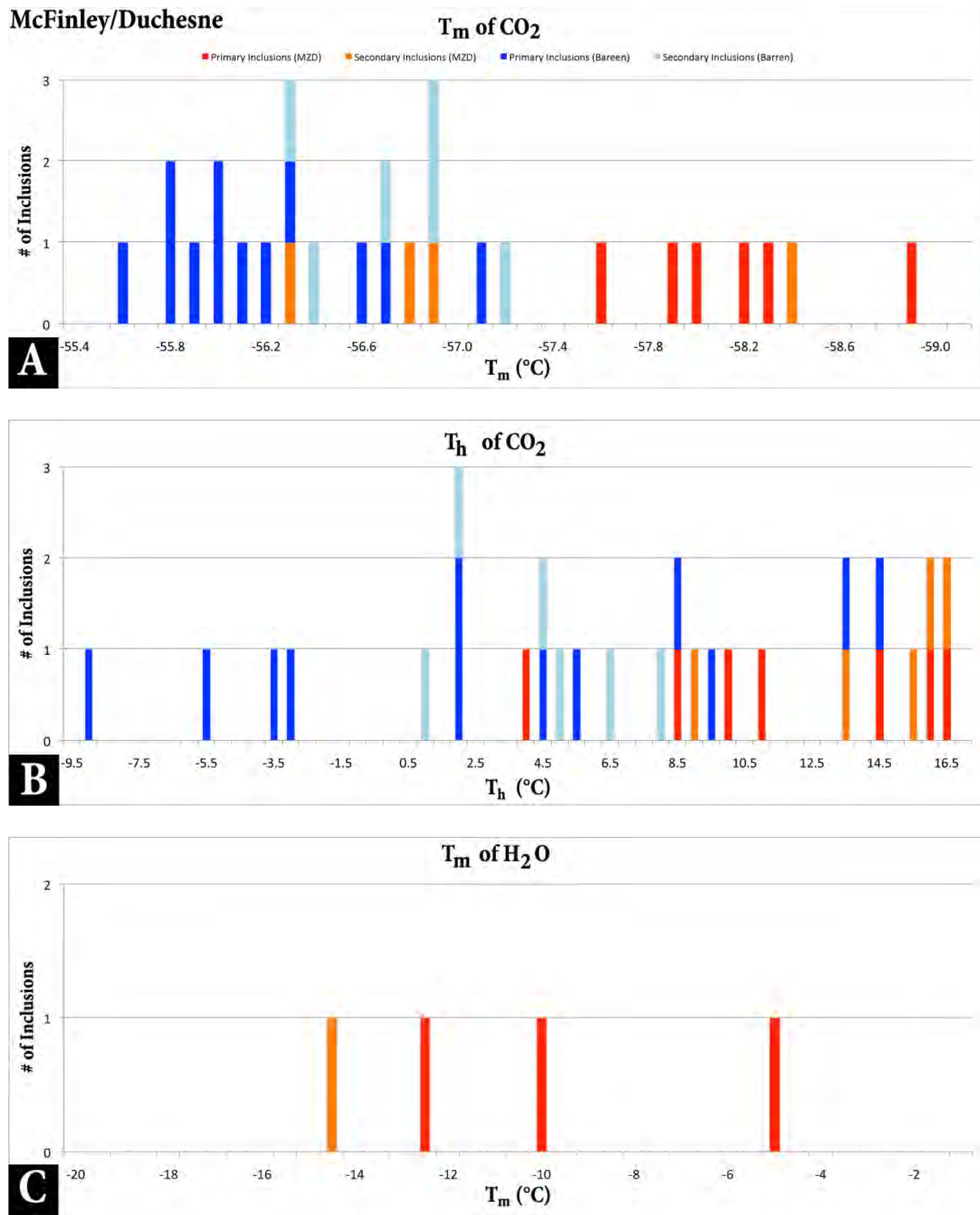


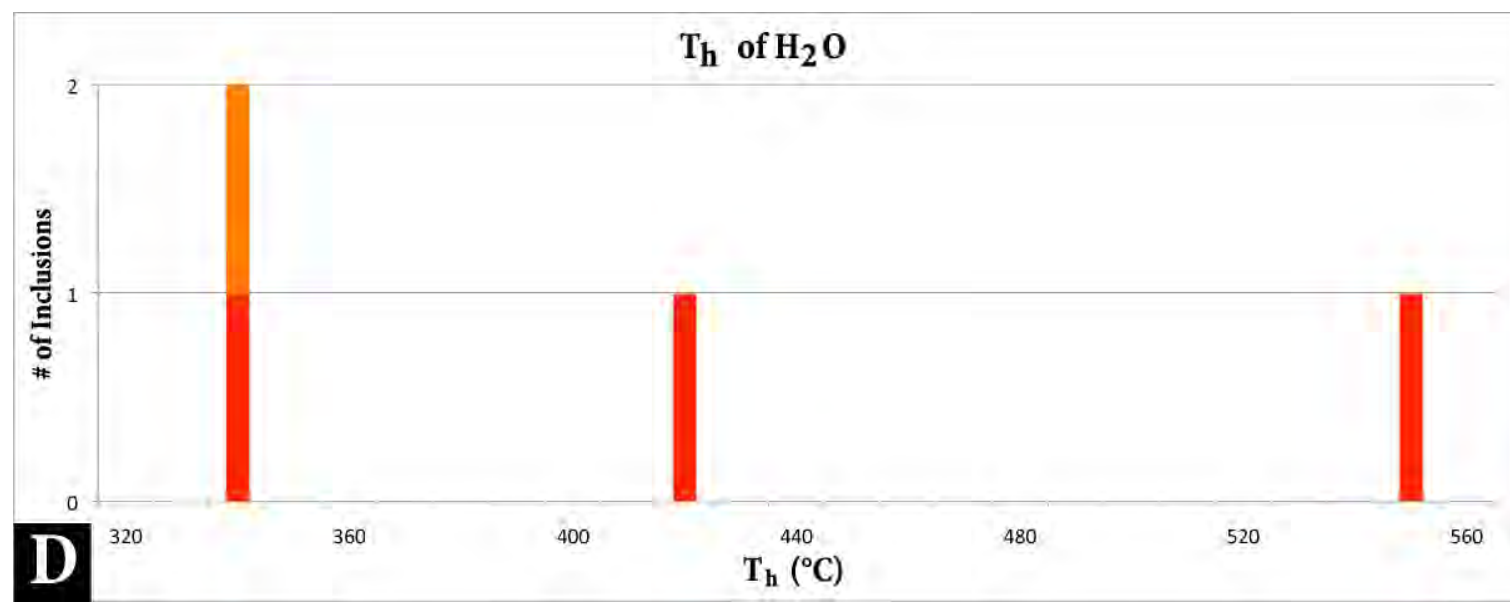

\section{Salinity}

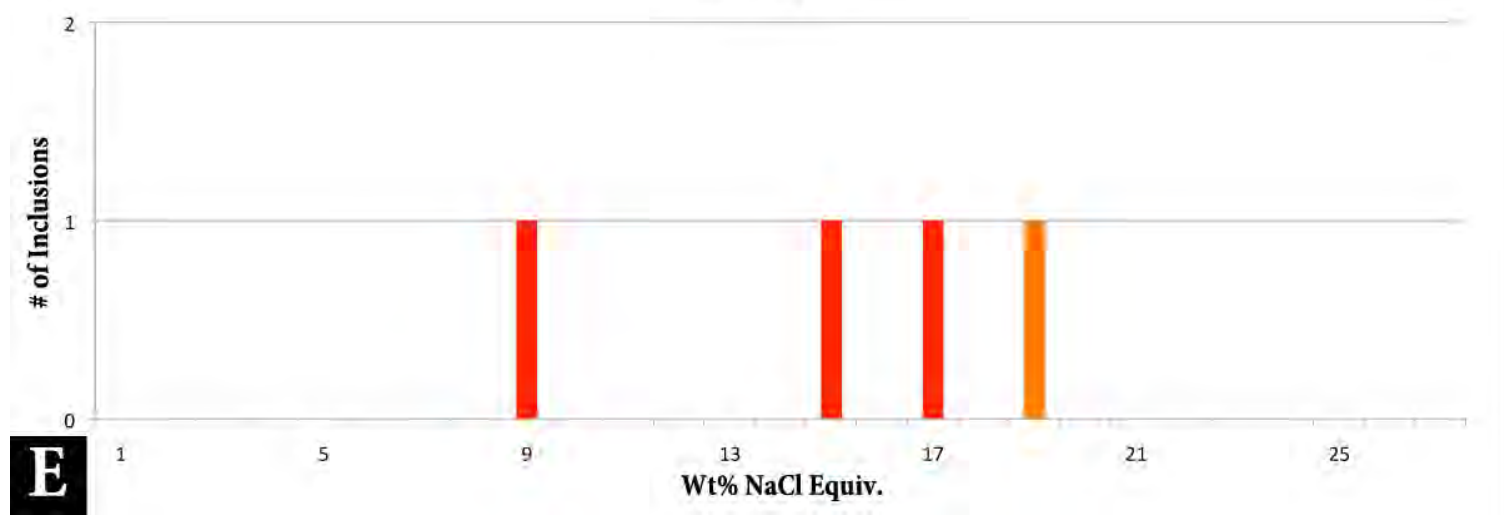

Figure 4.18 - Fluid inclusion data from the McFinley/Duchesne area: (A) Melt temperature of $\mathrm{CO}_{2}$ inclusions; (B) Homogenization temperature of $\mathrm{CO}_{2}$ inclusions; (C) Melt temperature of $\mathrm{H}_{2} \mathrm{O}$ inclusions; (D) Homogenization temperature of $\mathrm{H}_{2} \mathrm{O}$ inclusions; (E) Salinity of aqueous inclusions.

\subsection{6 - Cochenour Area}

This mineralization primarily comprises large quartz veins that are generally surrounded by haloes of intensely silicified host rocks (silica flooding) (Brooking et al., 2009). Primary fluid inclusions are large $(\sim 20-40 \mu \mathrm{m})$ whereas secondary inclusions range in size from $\sim 10-20 \mu \mathrm{m}$. Aqueous inclusions are closely related to mineralized areas and dominate over carbonic inclusions, which are rare. No threephase inclusions are present and liquid-vapor ratios of the aqueous and carbonic 
inclusions are constant.

The primary carbonic inclusions have an average $\mathrm{T}_{\mathrm{m}}$ of $-58.4 \pm 0.3^{\circ} \mathrm{C}(1 \sigma$; $\mathrm{n}=3$ ) (Fig. 4.19A) and $\mathrm{a} \mathrm{T}_{\mathrm{h}}$ of $15.2 \pm 1.2^{\circ} \mathrm{C}(1 \sigma ; \mathrm{n}=3$ ) (Fig. 4.19B). The primary aqueous inclusions have an average $\mathrm{T}_{\mathrm{m}}$ of $-13.8 \pm 2.1^{\circ} \mathrm{C}(1 \sigma ; \mathrm{n}=5)$ (Fig. $\left.4.19 \mathrm{C}\right)$ and $\mathrm{a}$ $\mathrm{T}_{\mathrm{h}}$ of $245.4 \pm 44.5^{\circ} \mathrm{C}(1 \sigma ; \mathrm{n}=5)$ (Fig. 4.19D)

No secondary carbonic inclusions were measured due to their small size, whereas the secondary aqueous inclusions have an average $\mathrm{T}_{\mathrm{m}}$ of $-14.8 \pm 2.0^{\circ} \mathrm{C}(1 \sigma$; $\mathrm{n}=6)$ and $\mathrm{a} \mathrm{T}_{\mathrm{h}}$ of $257.5 \pm 69.7^{\circ} \mathrm{C}(1 \sigma ; \mathrm{n}=6)$. Primary aqueous inclusions dominate over all other inclusions, making secondary carbonic inclusions difficult to locate. The average salinity of primary aqueous inclusions is $17.5 \pm 1.8 \mathrm{wt} \% \mathrm{NaCl}$, whereas secondary aqueous inclusions have an average salinity of $18.5 \pm 2.4 \mathrm{wt} \%$ $\mathrm{NaCl}$ (Fig. 4.19E). 

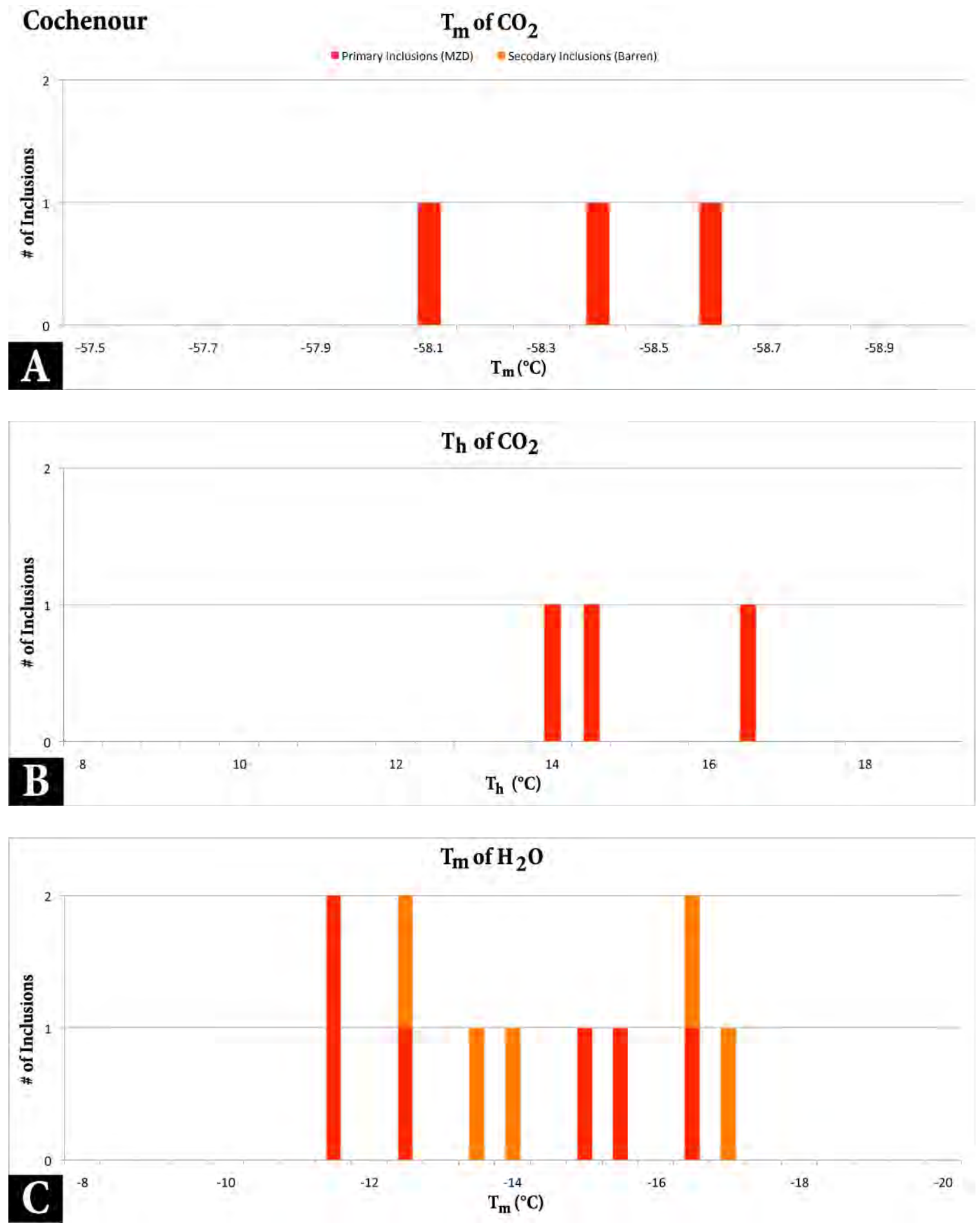

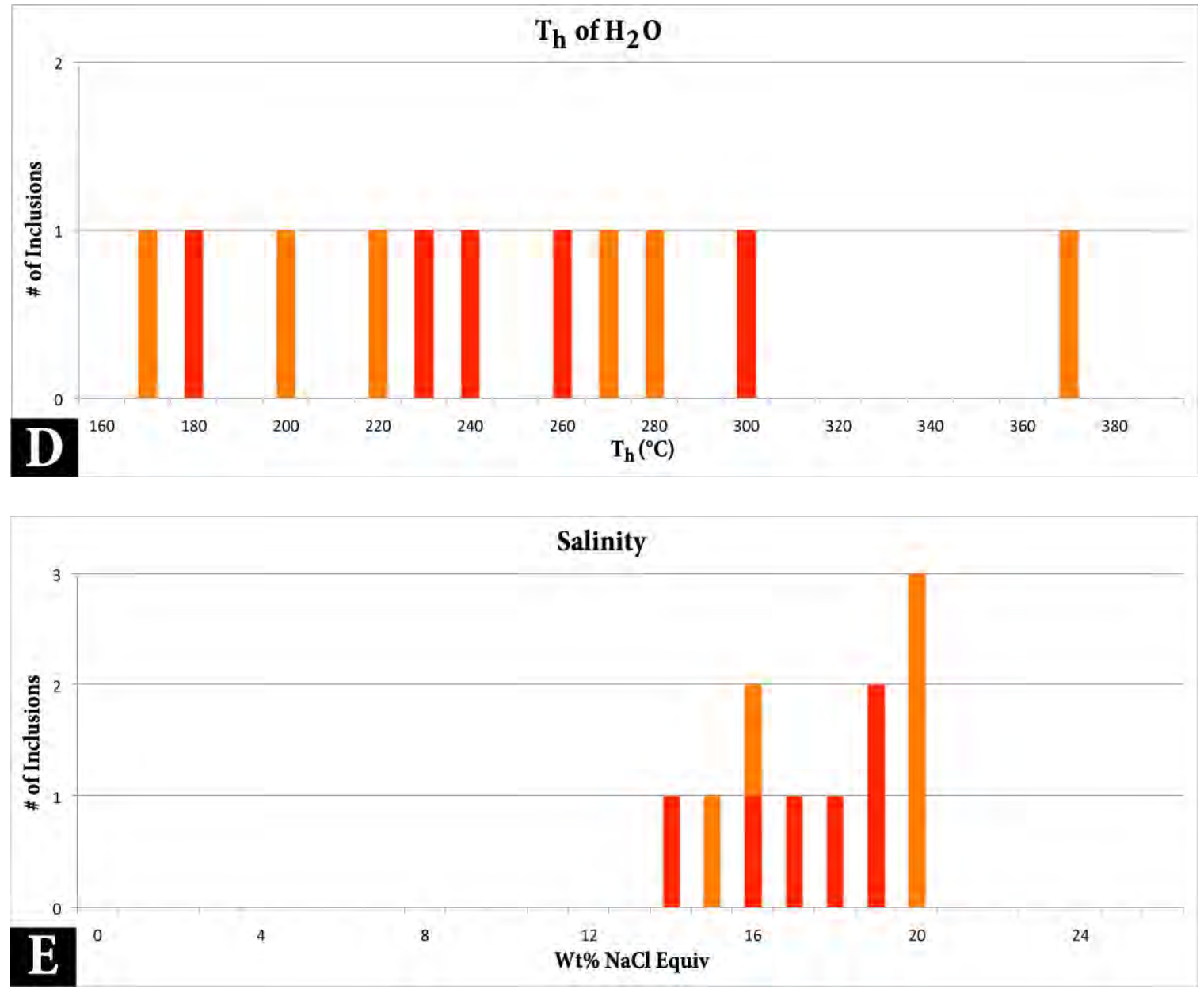

Figure 4.19 - Fluid inclusion data from Cochenour 20L old workings: ((A) Melt temperature of $\mathrm{CO}_{2}$ inclusions; (B) Homogenization temperature of $\mathrm{CO}_{2}$ inclusions;

(C) Melt temperature of $\mathrm{H}_{2} \mathrm{O}$ inclusions; (D) Homogenization temperature of $\mathrm{H}_{2} \mathrm{O}$ inclusions; (E) Salinity of aqueous inclusions.

\section{3 - Stable Isotope Data}

\subsection{1 - $\delta^{13} C \& \delta^{18} O$ Values of Carbonate Veins}

The early carbonate veins (typically ferroan dolomite) in the EB area (Fig. 4.20) were analyzed for $\mathrm{C}$ and $\mathrm{O}$ isotopes (Table 4.1; Appendix $\mathrm{E}$ ). $\delta^{13} \mathrm{C}$ (PDB) values range from -2.07 to $+3.74 \%$ and the $\delta^{18} 0$ (SMOw) values range from 11.12 to 17.86 $\%$. The majority of the samples have similar isotopic compositions. However, $\delta^{18} \mathrm{O}$ (smow) values of ferroan dolomite from Chevron, Marboy (surface), and Tuckers Knob 
each produce their own outlying groups that have distinctly different isotopic values than the rest of the locations (figure 4.21). Quartz and calcite veins occur in select areas (indicated in Table 4.1) that may influence the isotopic value of that specific vein set.

Table 4.1 - Summary of $\delta^{18} \mathrm{O}_{\text {(SMOW-) }}$ and $\delta^{13} \mathrm{C}_{\text {(PDB) }}$ values of ferroan dolomite in early carbonate veins

\begin{tabular}{|c|c|c|c|}
\hline Location & $\delta^{18} \mathbf{O}_{\text {(sмоw) }}$ & $\delta^{13} C_{(\text {PDB })}$ & \# of Analyses \\
\hline $\begin{array}{l}\text { Tuckers Knob } \\
\text { Colloform Veins }\end{array}$ & 14.68 to $15.34 \%$ & 1.96 to $2.11 \%$ & 2 \\
\hline $\begin{array}{c}\text { Tuckers Knob } \\
\text { Breccia Carbonate }\end{array}$ & 16.18 to $17.17 \%$ & 3.33 to $3.74 \%$ & 2 \\
\hline $\begin{array}{l}\text { Tuckers Knob with } \\
\text { Calcite Veinlets }\end{array}$ & 14.58 to $14.98 \%$ & 0.06 to $0.44 \%$ & 2 \\
\hline Marboy & 15.24 to $16.35 \%$ & 0.98 to $1.82 \%$ & 3 \\
\hline $\begin{array}{l}\text { Marboy (Quartz } \\
\text { Injected) }\end{array}$ & 16.32 to 17.86 & 2.50 to $2.65 \%$ & 2 \\
\hline $\begin{array}{l}\text { Marboy (South } \\
\text { Surface) }\end{array}$ & $11.12 \%$ & $-0.16 \% 0$ & 1 \\
\hline Chevron & 17.31 to $17.79 \%$ & -2.05 to $-0.97 \%$ & 4 \\
\hline Abino (Surface) & 14.94 to $17.05 \%$ & 0.91 to $1.97 \%$ & 4 \\
\hline Abino (Core) & $13.71 \%$ & $1.07 \%$ & 1 \\
\hline McFinley & 16.58 to $17.96 \%$ & 0.76 to $1.54 \%$ & 3 \\
\hline
\end{tabular}

Blind Standard C-44:

$\delta^{13} \mathrm{C}(\mathrm{PDB})=-1.77, \mathrm{n}=2$, st.dev. $=0.08$

$\delta^{18} \mathrm{O}($ VSMOW $)=8.96, \mathrm{n}=2$, st.dev.$=0.09$ 


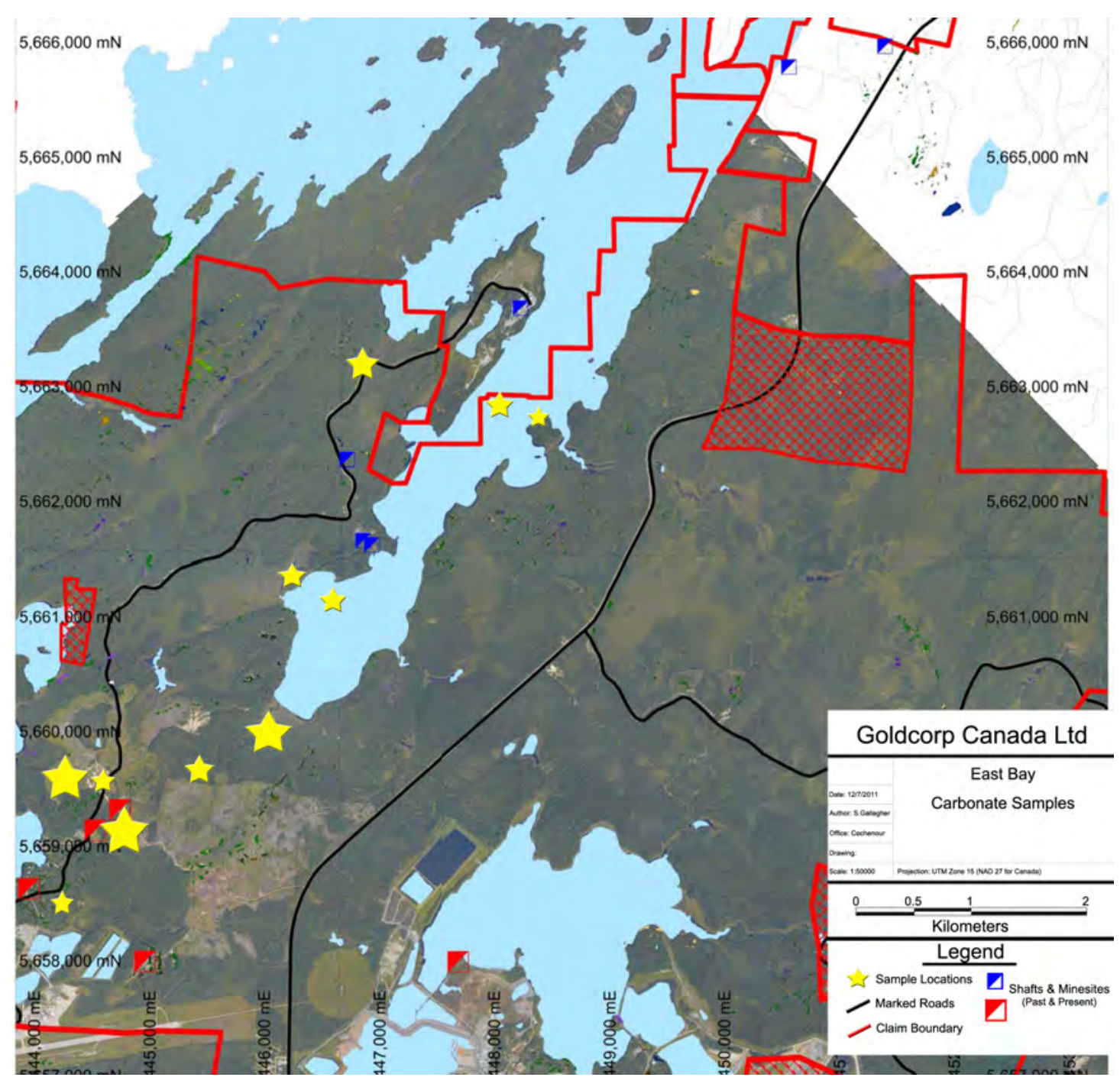

Figure 4.20 - Carbonate vein sample locations throughout East Bay, indicated by yellow stars. Size of star reflects the number of samples from that location. 


\section{Carbonate Vein Isotope Data}

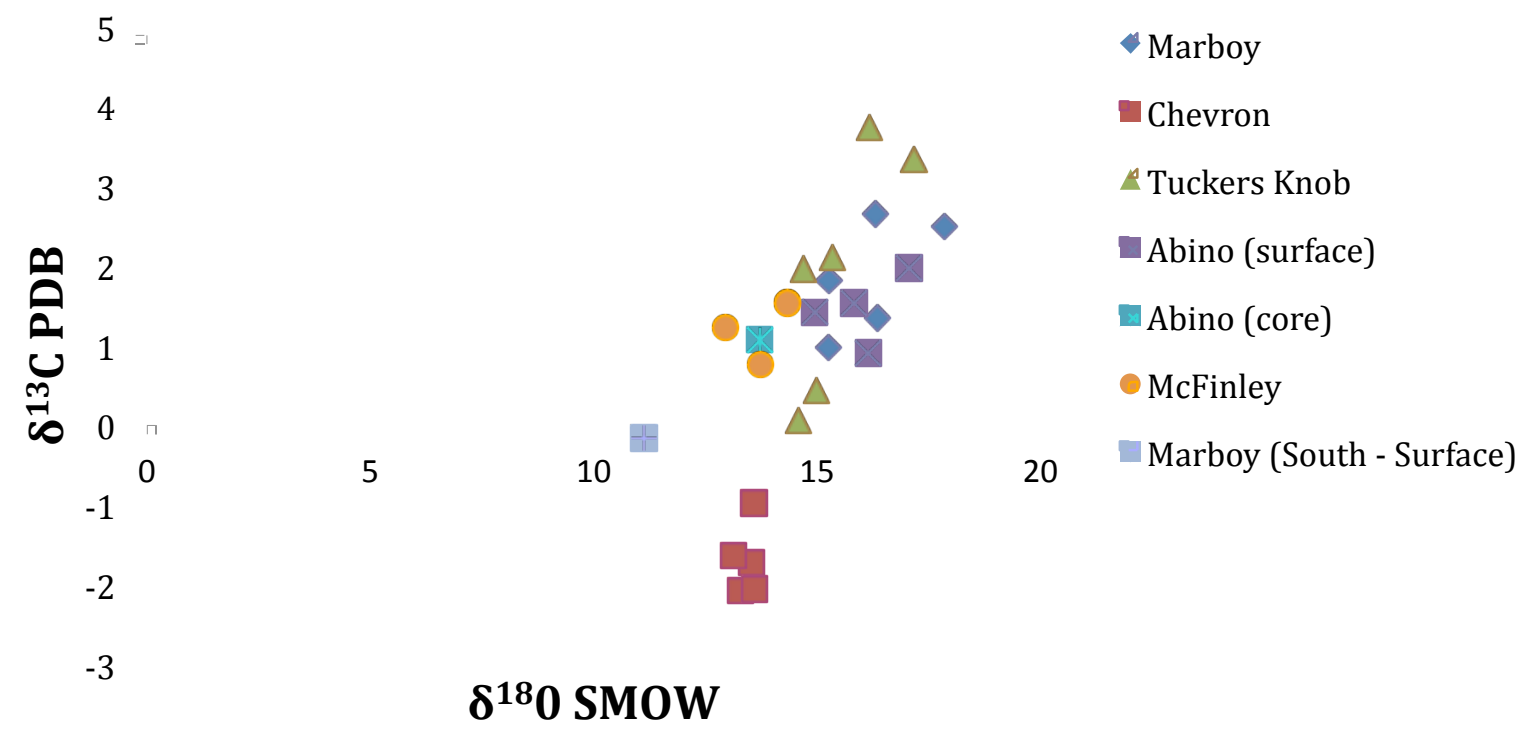

Figure 4.21 - Carbon and oxygen isotopic compositions for carbonate veins (ferroan-dolomite/ankerite) that occur throughout the East Bay Trend. The Chevron, Tuckers Knob, and Marboy (surface) carbonates clearly occur as outliers with respect to the others.

\subsection{2 - $\delta^{18} O$ of Quartz Veins (Auriferous \& Barren)}

Oxygen isotopic data from quartz veins throughout the EB area are summarized in Tables 4.2 and 4.3. A complete data set can be found in Appendix F. Auriferous quartz veins have higher $\delta^{18} 0$ values ranging from 9.6 to $13.1 \%$, whereas barren samples give $\delta^{18} 0$ values from 0.0 to $8.5 \%$. In the Abino area, the $\delta^{18} 0$ values of auriferous quartz veins are lower $(4.1 \%$ ) than barren quartz veins (8.4\%o). 
Table 4.2 $-\delta^{18} 0$ isotopic values from the various deposit areas and showings along the East Bay Trend as measured by SIMS.

\begin{tabular}{ccccccc}
\hline $\begin{array}{c}\text { Sample } \\
\text { Type }\end{array}$ & Cochenour & $\begin{array}{c}\text { Tuckers Knob* } \\
\text { (qtz veins) }\end{array}$ & Marboy & Chevron & Abino & Duchesne \\
\hline Barren & N/A & $\begin{array}{c}5.3 \pm 0.3 \% \text { \& } \\
5.8 \pm 1.6 \% 0\end{array}$ & $0.0 \pm 1.1 \% 0$ & $5.3 \pm 0.7 \% 0$ & $8.4 \pm 1.0 \% 0$ & $8.5 \pm 0.6 \% 0$ \\
& & & & & \\
Mineralized & $13.1 \pm 0.4 \% 0$ & N $/ \mathrm{A}$ & $11.2 \pm 0.6 \% 0$ & $9.6 \pm 0.7 \% 0$ & $4.1 \pm 0.9 \% 0$ & $11.8 \pm 0.6 \% 0$ \\
\hline
\end{tabular}

* Samples from Tuckers Knob are the late quartz veins that are barren, not the quartz-tourmaline veins.

\subsection{3 - $\delta^{34} S$ of Quartz Vein Pyrite}

The foremost sulphides present are pyrite, followed by phyrrhotite. Other sulphides that occur are Arsenopyrite and minor chalcopyrite, sphalerite and galena (Fig. 4.22).

$\delta^{34} \mathrm{~S}$ values of pyrite from quartz veins in East Bay were measured using SIMS (Fig. 4.23) and range from 2.2 to $5.3 \%$ (Table 4.4; Fig. 4.24). A complete data set can be found in Appendix F. All grains were typically homogenous, with the exception of sample MB891-05 from Marboy, which had distinctly different groupings of isotopic values (Fig. 4.23). One portion of the pyrite grain has $\delta^{34} \mathrm{~S}$ values that range from 2.0 to $2.8 \%$, whereas the other area ranges from 3.5 to 5.5\% (Fig. 4.23). 


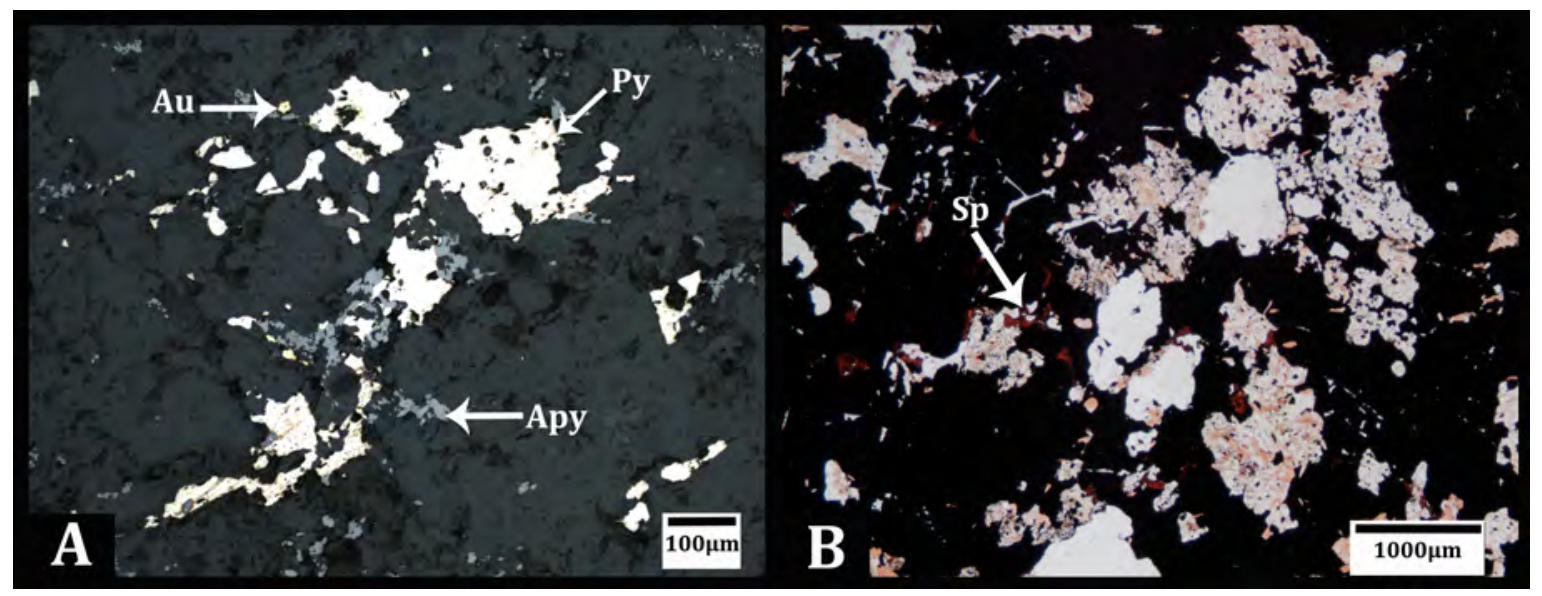

Figure 4.22 - Sulphides from East Bay (A) Presence of pyrite, arsenopyrite and small flecks of gold from drill hole MB89-1 at McMarmac, (B) Presence of sphalerite with pyrite and phyrrhotite (opaque) from drill hole EB10040 at Duschene.

Table 4.3 - Pyrite sulphur isotope data from throughout East Bay

\begin{tabular}{lcccc}
\hline Sample & Property & $\boldsymbol{\delta}^{\mathbf{3 4}} \mathbf{S}(\mathrm{CDT})$ & St. Dev. & \# of Analyses \\
\hline MB891-05 & Marboy & $3.5 \% 0$ & 1.2 & 8 \\
MB10034-2 & Marboy & $4.4 \% 0$ & 0.4 & 5 \\
ABU51-02 & Abino & $3.7 \% 0$ & 1.3 & 5 \\
ABU51-01 & Abino & $4.7 \% 0$ & 1.0 & 3 \\
EB903-01 & Chevron & $5.3 \% 0$ & 0.9 & 5 \\
EB9017-01 & Chevron & $4.0 \% 0$ & 1.0 & 4 \\
SG11-171C & Tuckers Knob & $2.2 \% 0$ & 0.5 & 3 \\
\hline
\end{tabular}




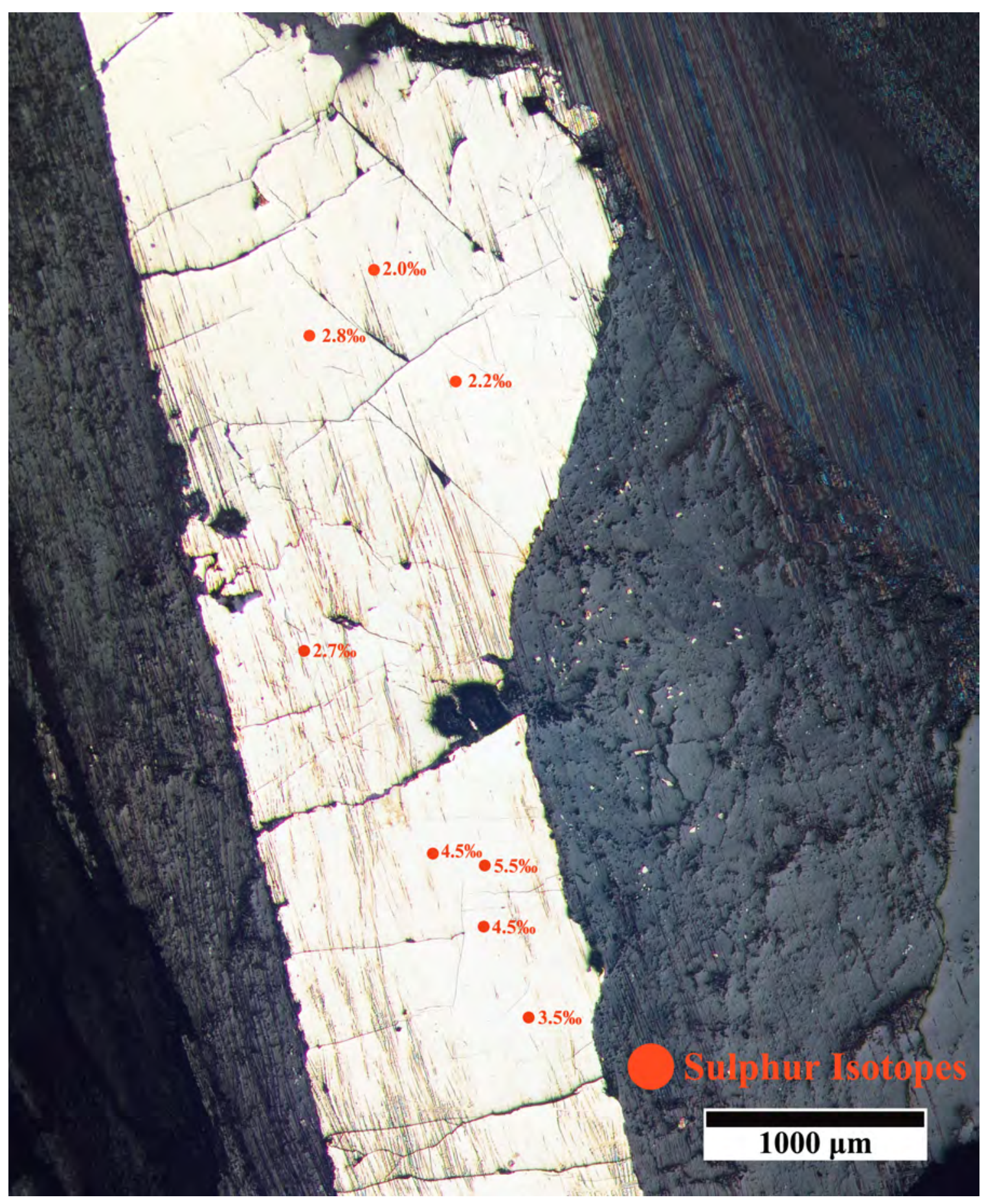

Figure 4.23 - Photomicrograph of pyrite in sample MB891-5 from Marboy with SIMS in-situ sulphur isotope analysis points. A distinct shift in $\delta^{34} \mathrm{~S}$ values is present between the two areas of analysis, producing a zoned appearance. 


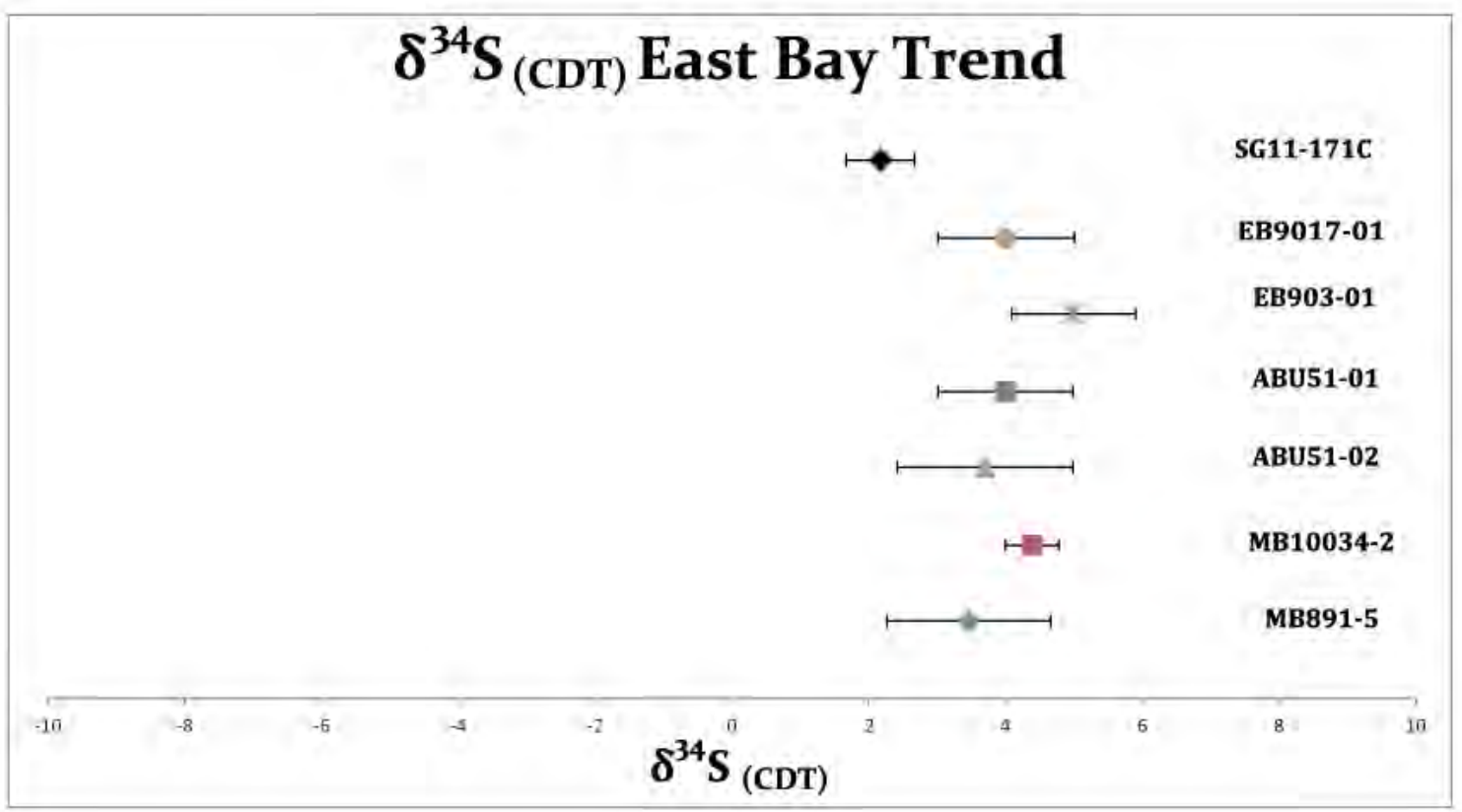

Figure 4.24 $-\delta^{34} \mathrm{~S}(\mathrm{CDT})$ values of pyrite grains from several deposit areas along the East Bay Trend

\subsection{4 - $\delta^{18} \mathrm{O}$ of Quartz-Tourmaline Veins}

Quartz-tourmaline veins were selected for 0 isotopic analysis from the Marboy and Abino properties. Sample SG11-174B from the Marboy area contains dravite, whereas SG11-177B from Abino contains elbaite (Table 4.5; Appendix F). In these samples, both tourmaline and quartz were analyzed for their $\delta^{18} 0$ values because quartz and tourmaline were in textural equilibrium and could be used as a thermometer. Dravite from sample SG11-174B (Marboy) has a $\delta^{18} 0$ value of $9.3 \pm$ $1.6 \%$ and the quartz has a $\delta^{18} 0$ value of $17.3 \pm 1.2 \%$, whereas the elbaite from sample SG11-177B (Abino) gives a $\delta^{18} 0$ value of $9.6 \pm 0.8 \%$ and the quartz has a $\delta^{18} \mathrm{O}$ value of $17.7 \pm 1.2 \%$ (Table 4.5 ). Equilibrium temperatures were calculated using the calibration of Blamart (1991): 
$1000 * \ln \alpha_{\text {Quartz-Tourmaline }}=\mathrm{A} * 10^{6} / \mathrm{T}^{2}+\mathrm{B} * 10^{3} / \mathrm{T}+\mathrm{C}$

Where, $\mathrm{A}=2.230, \mathrm{~B}=0.00, \mathrm{C}=-1.07$

The calculated temperature for quartz and dravite from Marboy and is $222^{\circ} \mathrm{C}$ and the temperature of quartz and elbaite from Abino is $219^{\circ} \mathrm{C}$. These temperatures are lower than the temperatures reported by Chi et al. (2010) for quartz-tourmaline gold veins from the Buffalo Mine and are much lower than the reported temperatures for auriferous quartz veins from the RLGM (Tarnocai, 2000; Chi et al., 2006).

Using the equilibrium temperature and the quartz-water fractionation factor of Zheng (1993):

$1000 * \ln \alpha_{\text {Quartz-H2O }}=A * 10^{6} / \mathrm{T}^{2}+\mathrm{B} * 10^{3} / \mathrm{T}+\mathrm{C}$

Where, $\mathrm{A}=4.480, \mathrm{~B}=-4.77, \mathrm{C}=1.71$

the $\delta^{18} 0$ value for the fluid that precipitated quartz and tourmaline was $7.0 \%$ at Marboy and 7.2\%o at Abino. These values are similar to what Chi et al. (2010) calculated from quartz-tourmaline veins at the Buffalo Mine, which range between 5.6 and $7.1 \%$. 
Table 4.4 $-\delta^{18} \mathrm{O}_{\text {mineral }}$ isotope values, equilibrium temperatures, and $\delta^{18} \mathrm{O}_{\text {fluid }}$ source fluid composition of quartz-tourmaline mineral pairs from quartz-tourmaline vein

\begin{tabular}{|c|c|c|c|c|}
\hline Sample & Mineral & $\delta^{18} 0$ (Mineral) & Temperature $\left({ }^{\circ} \mathrm{C}\right)$ & $\begin{array}{l}\delta^{18} 0_{\text {vsmow }} \\
\text { (Fluid) }\end{array}$ \\
\hline \multirow[t]{3}{*}{ SG11-174B } & Dravite & $9.3 \pm 1.6 \%$ & & \\
\hline & & & $222 \pm 50^{\circ} \mathrm{C}$ & $7.0 \%$ \\
\hline & Quartz & $17.3 \pm 1.2 \%$ & & \\
\hline \multirow[t]{2}{*}{ SG11-177B } & Elbaite & $9.6 \pm 0.8 \%$ & & \\
\hline & Quartz & $17.7 \pm 1.2 \%$ & $219 \pm 50^{\circ} \mathrm{C}$ & $7.2 \%$ \\
\hline
\end{tabular}

\section{4 - Geochronology Data}

\subsection{1 - U-Pb Geochronology using SHRIMP II}

Titanite was identified within quartz veins from the Duchesne area of the EBT. Titanite grains occur along the wallrock margin, ranging in size from $25-150$ $\mu \mathrm{m}$ and appear to be contemporaneous with the quartz veins based on textural relationships (Fig. 4.25). With titanite grains of this size, it is possible to use in-situ methods to date the grains, providing an age for the vein.

Titanite was analyzed by the U-Pb method using a sensitive high-resolution mass spectrometer (SHRIMP II) instrument from the Australian National University. Uranium and lead isotopic ratios, ${ }^{206} \mathrm{~Pb} /{ }^{238} \mathrm{U}$ and ${ }^{207} \mathrm{~Pb} /{ }^{235} \mathrm{U}$ (Appendix I), for the titanite grains were plotted on concordia diagrams (Fig 4.26). The data is nearly concordant with an upper intercept of $2704 \pm 60 \mathrm{Ma}$ and an MSWD of 0.076 . The SHRIMP data was calculated using an average from 11 data points measured from two large titanite grains. 


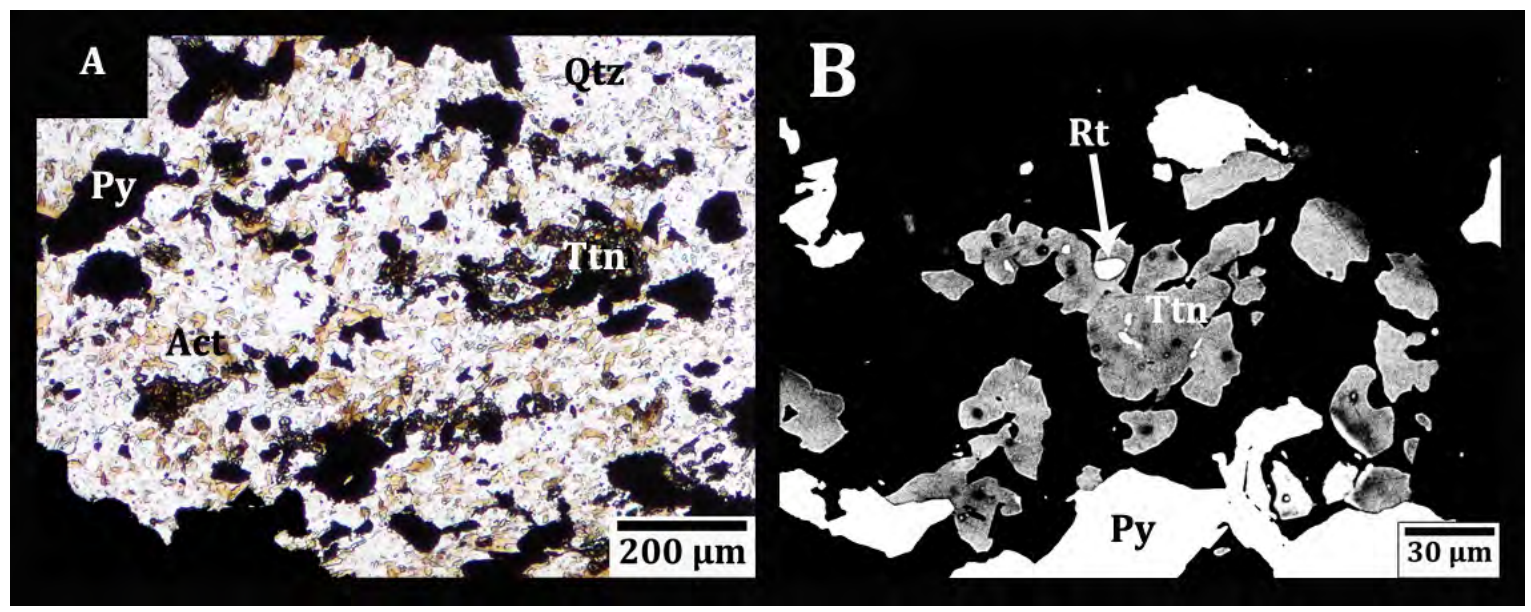

Figure 4.25 - Titanite grains. A) Titanite in the quartz vein - wallrock alteration halo; B) Titanite grains adjacent to pyrite.

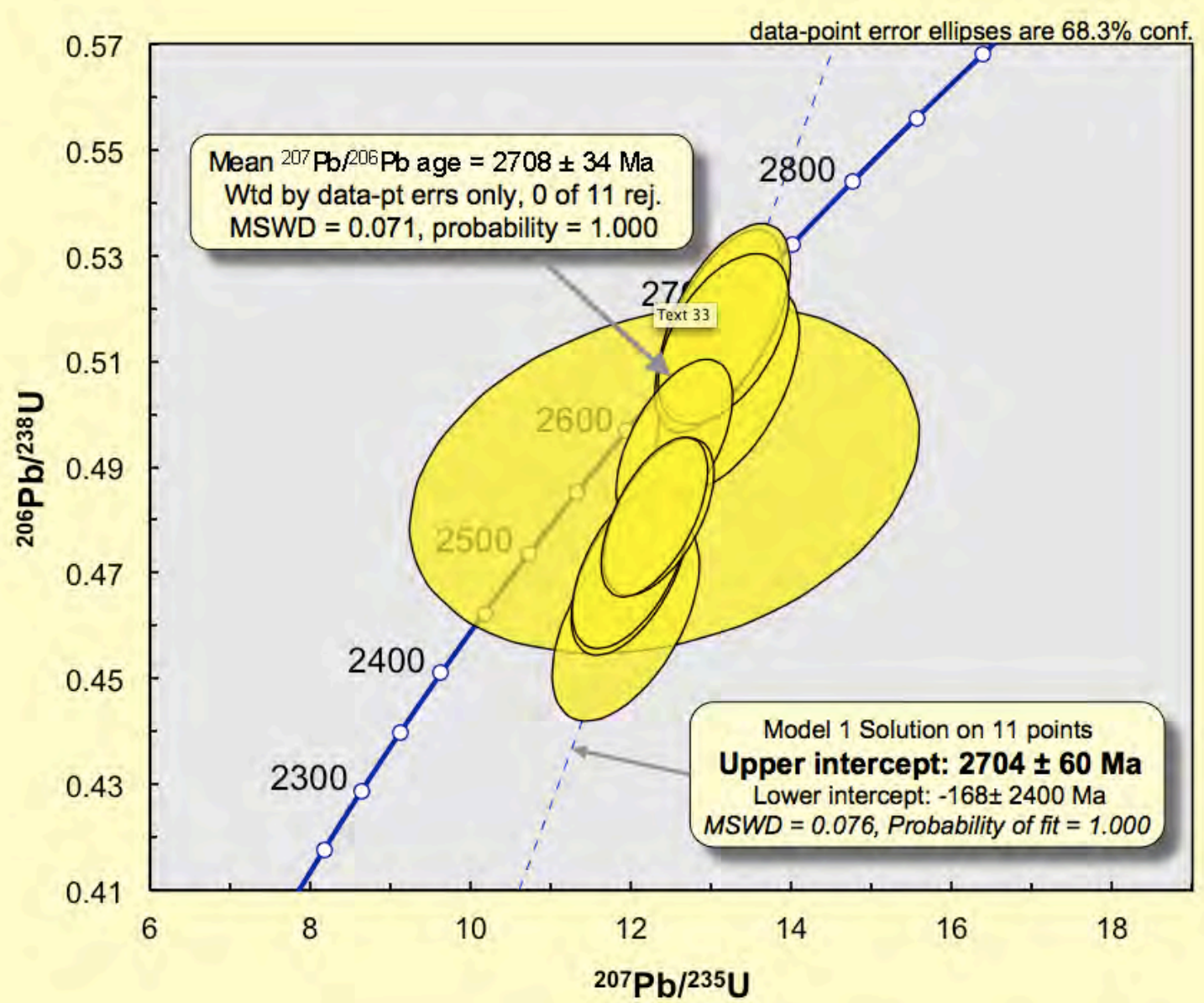

Figure 4.26 - U-Pb results from in situ SHRIMP isotopic analysis from vein-hosted titanite. 


\section{CHAPTER 5 - DiscuSSION}

The RLGB has been the focus of many studies over the last 50 years, but the EB area has received considerably less attention because of its perceived lack of gold potential. The few outcrops in this area have been extensively mapped, but no other detailed studies have been carried out, due to the extremely limited outcrop. To produce a better map, future studies must use drill data and extensive outcrop stripping is required. This project focuses on the assortment of fluids, stable isotopes and the relative timing of veins throughout the EB area. By using a different approach than past studies, a greater understanding of the belt has been established.

This chapter begins with a brief summary of typical mechanisms of gold deposition in fluid system with a summary of the findings of the fluid inclusion study and the fluid characteristics identified in the EB area. A description of each major veining event follows, accompanied by petrogenesis and relevant isotope analyses to each of those veining events. The discussion concludes with the application of potential genetic models and a comparison with other gold deposits from the RLGB, as well as from around the world.

\section{1 - General mechanisms of gold deposition}

Fluid inclusion data are typically used to determine the minimum temperature, salinity, and composition of the fluids, from which mechanisms of gold transport and deposition can be inferred. Although they provide a complex, and 
fragmentary record of past fluids, they provide a rich source of small but valuable clues regarding the fluid history of ore systems (Roedder, 1984).

There are five mechanisms that are widely accepted for the deposition of gold. These are, (1) immiscibility, (2) effervescence and boiling, (3) fluid mixing, (4) sulphidation, and (5) carbonatization. Evidence for immiscibility, effervescence or boiling, and fluid mixing are generally derived from primary fluid inclusions, which can be related to the initial growth of a mineral associated with gold mineralization (Bodnar, 2003). Secondary fluid inclusions that occur along healed microfractures provide information on subsequent fluids that have interacted with the deposit (Shepherd, 1985).

\subsection{1 - Immiscibility}

The immiscibility of fluids during vein emplacement is considered an important mechanism for gold deposition in a variety of orogenic and epithermal (also termed epizonal) lode gold deposits (Diamond, 1990; Bowers, 1991; Craw et al., 1993; Coulibaly et al., 2007). Fluid inclusions occur in quartz veins that are texturally coeval with gold-bearing zones that precipitated under the same conditions (Roedder, 1984; Craw et al, 1993). The primary aqueous-carbonic inclusions often display higher homogenization temperatures than the purely aqueous inclusions, which is indicative of fluid immiscibility (Roedder, 1984).

A drop in pressure during fault movement can cause fluid immiscibility during fracture propogation, a decrease in temperature or both a decrease in pressure and temperature (Harraz, 2002). Inclusions are $\mathrm{H}_{2} \mathrm{O}-\mathrm{CO}_{2}$-bearing, and 
show variable liquid-vapor ratios that indicate heterogeneity of the trapped liquidvapor mixtures (Harraz, 2002). In addition, the wide range of $\mathrm{CO}_{2}: \mathrm{H}_{2} \mathrm{O}$ ratios represent the separation of two fluid end members possibly due to either unmixing of the original fluid through a pressure decrease or $\mathrm{CO}_{2}$ phase separation (Mumin et al., 1996). Aqueous and carbonic phases are both observed in quartz, with carbonic inclusions dominating the assemblages (Coulibaly, 2007). Consequently, these inclusions are interpreted to represent two immiscible coexisting fluids or separation of phases accompanying mineralization (Ramboz et al., 1982).

\subsection{2 - Effervescence and Boiling}

Boiling in a hydrothermal system is the process when vapor-saturation is achieved by decreasing the pressure in the system and is particularly relevant in high-level $(<4 \mathrm{~km})$ systems (Robb, 2005). This can be achieved by upward emplacement of magma or mechanical failure of the chamber and is often refered to as "first boiling". Boiling can also be achieved through progressive crystallization of anhydrous minerals while the pressure remains constant and is referred to as "second boiling", often occurring in deep-level (>4 km) systems (Robb, 2005). This process involves the physical separation of the liquid and vapour phases and if sufficient heat is supplied to the system, the conversion of liquid to vapour will terminate (Shepherd et al., 1985). The process of fluid separation destabilizes the bisulphide complexes, allowing gold to precipitate.

Effervescence is similar to boiling, but occurs at deeper crustal levels (typically >3-5 km, but can occur deeper with correct P-T conditions) where the 
fluid phases separate (unmixing) as a result of fluctuations in pressure (Robb, 2005). It is a process that occurs less commonly than boiling, as it requires significant $\mathrm{CO}_{2}$ saturation within the fluid system. Given that fluid pressure fluctuates in an active hydrothermal system, several $\mathrm{CO}_{2}$ expulsions from the fluid system (pressure drops) will occur, resulting in several effervescing events. Low homogenization temperatures can be interpreted as the result of $\mathrm{CO}_{2}$ effervescence from a $\mathrm{CO}_{2}$-saturated fluid due to pressure fluctuations at the time of entrapment (Robert \& Kelly, 1987). Fluid inclusions with different liquid/vapor ratios of $\mathrm{CO}_{2}$ in one sample that yield similar homogenization temperatures result from an effervescing system (Lee, 2003). Diamond (1994), recognized that when these conditions occur in an effervescing system, the homogenization temperatures can be regarded as the true trapping temperature without requiring the application of a pressure correction.

Gold can be transported as a bisulphide complex in an aqueo-carbonic fluid. A change in $\mathrm{pH}$ and $\mathrm{fO}_{2}$ related to effervescence can destabilize gold-bisulphide complexes and promote gold and sulfide precipitation (Lee, 2003; Zoheir, 2008).

\subsection{3 - Fluid Mixing}

The mixing of fluids, such as a hot metal-rich fluid, mixing with a cooler, dilute solution, is considered to be a significant depositional mechanism of metals by reducing solubility and destabilizing gold-ligand complexes (Robb, 2005). A wide range of homogenization temperatures and a range of salinities from a single generation of aqueous fluid inclusions suggest fluid mixing. Mixing creates a 
continuum between two end-member fluids, producing fluid temperatures and salinities that follow distinct trends (Shepherd, 1985). In addition, highly variable $\mathrm{CO}_{2}: \mathrm{H}_{2} \mathrm{O}$ ratios are considered to indicate phase separation, fluid mixing, or multiple stages of fluid intrusion (Klein et al., 2000).

\subsection{4 - Wallrock Sulphidation}

Wallrock sulphidation occurs when gold is transported as a bisulphide complex in a hydrothermal fluid that reacts with the surrounding wallrocks. Higher iron content from the wallrocks generally favours the formation of iron sulphides by combining iron from the wallrock with sulphur from the mineralizing fluids. The removal of sulphur from the solution by reacting with iron in the wallrock destabilises the bisulphide complexes, leading to gold precipitation (Robb, 2005). The interaction of the suphide-rich fluids with the iron-rich host rock result in physiochemical changes in the fluid (e.g., T, pH and fO2) that destabilizes goldbisulphide complexes, and precipitate gold and sulphides along the wallrock-vein interface (Kesler, 2004).

\subsection{5 - Wall-rock Carbonation}

Wall-rock carbonation (or carbonatization) is the process where carbonate forms during alteration of the surrounding rocks. This process is assisted by fluids with high partial pressures of $\mathrm{CO}_{2}\left(\mathrm{P}_{\mathrm{CO}}\right)$ and a neutral to alkaline $\mathrm{pH}$ (Robb, 2005). $\mathrm{CO}_{2}$-bearing hydrothermal fluids react with iron-rich minerals (often magnetite) in the surrounding lithologies leading to the formation of Fe-rich carbonates 
(Hodkiewicz, 2003). These carbonates (typically ankerite) are a characteristic feature of Archean orogenic gold deposits and often represent the first stage of alteration. The second stage alteration assemblage is typically represented by quartz, muscovite, biotite, albite, and chlorite (McCuaig and Kerrich, 1998; Robb, 2005). This reaction oxidizes the Fe-rich rocks, which destabilizes gold-bisulphide complexes resulting in gold precipitation (Hodkiewicz, 2003). The carbonate that forms is a function of the host rock composition forming dolomite when associated with amphibolite or calcite when associated with a granitic host (Robb, 2005).

\section{2 -Gold Depositional Mechanisms along the EBT}

Gold mineralization occurs at numerous locations throughout the EB area, with the highest grades occuring in 0.15 to $1 \mathrm{~m}$ wide quartz-dominated vein systems similar to those in the Red Lake Gold Mine, with the exception of extensive quartztourmaline vein systems (Tarnocai, 2000, Mason-Apps, 2002, Dumoulin, 2009). Multiple fluid events are inferred to have infiltrated the EB area based on the distinct variety of vein types and fluid inclusions that occur throughout (MacGeehan \& Hodgson, 1982; Dubé et al., 2001).

Fluids trapped within primary fluid inclusions from mineralized veins are two-phase (liquid + vapour) or three phase (liquid + liquid + vapour). The fluid inclusion analysis carried out in this study show $\mathrm{CO}_{2}$ fluid immiscibility and effervescence are the dominant mechanisms contributing to gold deposition. These processes are described below and summarized in Table 5.1. Wall-rock carbonation may have also played a significant role in the EB area, due to the extensive 
carbonate veins and alteration, however it is difficult to confirm this mechanism from this study.

The microthermometric data show that the average homogenization temperatures $\left(\sim 250^{\circ} \mathrm{C}\right)$ are $\sim 75-150^{\circ} \mathrm{C}$ lower than typical mesozonal gold deposits (Wilkinson, 2001), which falls within the higher temperatures for epizonal deposits and the lower range for mesozonal deposits (Fig. 5.2). Salinity results indicate that the auriferous fluids in the RLGB are more saline than typical epizonal or mesozonal gold systems (Wilkinson, 2001). Salinities from select deposits of the EBT plot well above the ranges for epizonal and mesozonal systems (Fig. 5.2), indicating that there is possible fluid mixing with saline fluid at the deposit scale (Wilkinson, 2001).

The fluid inclusions also indicate that there are multiple depositional mechanisms that occur in the EBT deposits. Immiscibility is a dominant feature in nearly all study areas with an abundance of three-phase inclusions. Effervescence also occurs in most study areas (especially in barren samples), indicated by the distinct variation of liquid-vapour ratios. In addition to immiscibilty and effervescence, there is also evidence for fluid mixing at the Chevron deposit. The wide-ranging homogenization temperatures and salinities within fluid inclusion assemblages demonstrate this and represent two end-member fluids in a mixing system (Chi et al., 2010).

Chi et al., (2010) proposed fluid mixing as a mechanism at the Buffalo Mine property in Red Lake. Chi et al., (2010) also proposed that metamorphic fluids interacted with magmatic fluids from the numerous syn-tectonic intrusion (Chi, pers. Comm.). Mixing with a magmatic-porphyry fluid can account for elevated 
salinity in auriferous veins, relative to typical epizonal and mesozonal values (Wilkinson, 2000; Chi et al., 2010). This model requires further investigation to determine if it applies to more deposits in the Red Lake region.

Some of the East Bay deposits, such as Abino, contain significant amounts of sulphides that cluster along the margins of mineralized quartz veins, which is a feature common to wallrock sulphidation processes. Although sulphides are present in all deposits along the EBT, it is likely not a significant mechanism for gold deposition because sulphides are generally associated with barren veins. The sulphides may also represent a barren sulphur-rich fluid that post dates mineralization, however this cannot be confirmed at this time.

No single mechanism is responsible for the deposition of gold along the EBT, but rather a combination of mechanisms. Different mechanisms have greater importance at particular crustal levels or tectonic settings, making them more likely contributors to ore deposition based on the conditions of the given system, as seen in Figure 5.1 (Mikucki, 1998). 
Table 5.1 - Fluid inclusion and $\delta^{18} 0$ isotope data from barren and auriferous samples from all deposit areas and showings along EB.

\begin{tabular}{|c|c|c|c|c|c|c|c|c|c|c|}
\hline Localities & Cochenour & Tuckers Knob & \multicolumn{2}{|c|}{ Marboy } & \multicolumn{2}{|c|}{ Chevron } & \multicolumn{2}{|c|}{ Abino } & \multicolumn{2}{|c|}{ Duchesne } \\
\hline Deformation Zone & $\begin{array}{l}\text { Mine Trend/East } \\
\text { Bay Trend }\end{array}$ & East Bay Trend & \multicolumn{2}{|c|}{ East Bay Trend } & \multicolumn{2}{|c|}{ East Bay Trend } & \multicolumn{2}{|c|}{ East Bay Trend } & \multicolumn{2}{|c|}{ Mine Trend/East Bay Trend } \\
\hline Au Mineralization & Mineralized & $\begin{array}{l}\text { Weakly } \\
\text { Mineralized }\end{array}$ & Mineralized & Barren & Mineralized & Barren & Mineralized & Barren & Mineralized & Barren \\
\hline Carb FI & + & ++++ & ++ & ++++ & ++ & + & +++ & +++ & +++ & ++++ \\
\hline Aq-Carb FI & - & +++ & +++ & + & +++ & ++++ & - & + & - & - \\
\hline Aq FI & +++ & ++ & - & - & ++ & - & ++ & +++ & + & - \\
\hline \multicolumn{11}{|l|}{ Melt Temperatures } \\
\hline $\operatorname{Tm}_{\mathrm{CO} 2} \operatorname{Carb}$ FI $\left({ }^{\circ} \mathrm{C}\right)$ & -58.6 to -58.1 & -59.8 to -57.8 & $\begin{array}{l}-59.1 \text { to }- \\
57.1\end{array}$ & -58.7 to -55.9 & $\begin{array}{l}-57.6 \text { to }- \\
56.3\end{array}$ & -56.2 to -55.8 & $\begin{array}{l}-57.4 \text { to }- \\
56.4\end{array}$ & -58.7 to -56.7 & $\begin{array}{l}-58.9 \text { to }- \\
57.6\end{array}$ & -57.2 to -55.6 \\
\hline $\begin{array}{c}\mathrm{Tm}_{\mathrm{H} 20} \text { Aq-Carb FI } \\
\left({ }^{\circ} \mathrm{C}\right)\end{array}$ & - & -10.8 to -6.6 & $\begin{array}{c}-22.4 \text { to }- \\
11.8\end{array}$ & -10.1 & $\begin{array}{l}-11.1 \text { to - } \\
19.4\end{array}$ & -15.8 to -8.4 & - & -13.6 to -12.9 & - & - \\
\hline $\mathrm{Tm}_{\mathrm{H} 20} \mathrm{Aq}$ FI $\left({ }^{\circ} \mathrm{C}\right)$ & -16.5 to -11.6 & -20.8 to -18.6 & - & & -24.2 to -6.0 & - & $\begin{array}{c}-21.9 \text { to }- \\
18.7\end{array}$ & -15.9 to -11.5 & -12.5 to -5.4 & - \\
\hline \multicolumn{11}{|l|}{$\begin{array}{c}\text { Homogenization } \\
\text { Temperatures }\end{array}$} \\
\hline Th,o2 of Carb FI $\left({ }^{\circ} \mathrm{C}\right)$ & 14.2 to 16.6 & 8.8 to 19.1 & -3.0 to 19.0 & 1.6 to 26.3 & 5.1 to 19.2 & -2.4 to 7.2 & -3.9 to 21.9 & -0.3 to 18.8 & -7.7 to 16.8 & -9.4 to 14.7 \\
\hline $\begin{array}{c}\text { Th}_{\mathrm{H} 20} \text { of Aq-Carb FI } \\
\left({ }^{\circ} \mathrm{C}\right)\end{array}$ & - & 157.3.2 to 288.3 & $\begin{array}{c}292.4 \text { to } \\
398.8\end{array}$ & 232.7 & $\begin{array}{l}196.2 \text { to } \\
291.8\end{array}$ & $\begin{array}{c}192.3 \text { to } \\
384.4\end{array}$ & - & $\begin{array}{c}198.7 \text { to } \\
335.2\end{array}$ & - & - \\
\hline $\mathrm{Th}_{\mathrm{H} 20}$ of Aq FI $\left({ }^{\circ} \mathrm{C}\right)$ & 184.2 to 306.5 & 205.4 to 222.1 & - & - & $\begin{array}{l}155.8 \text { to } \\
364.7\end{array}$ & - & $\begin{array}{c}189.7 \text { to } \\
308.3\end{array}$ & $\begin{array}{l}194.6 \text { to } \\
291.4\end{array}$ & $\begin{array}{l}345.2 \text { to } \\
559.4\end{array}$ & - \\
\hline $\begin{array}{c}\text { Salinity (wt\% } \mathrm{NaCl} \\
\text { equiv.) }\end{array}$ & 14.6 to 19.4 & 9.6 to 15.4 & 15.8 to 24.0 & 13.5 & 9.2 to 25.5 & 10.9 to 19.4 & 9.5 to 23.2 & 14.3 to 19.4 & 8.1 to 16.2 & - \\
\hline$\delta^{18} \mathbf{O}$ & $13.1 \%$ & $5.3 \% 0,5.8 \% 0$ & $11.2 \% 0$ & $0.0 \% 0$ & $9.6 \% 0$ & $5.3 \% 0$ & $4.1 \% 0$ & $8.4 \%$ & $11.8 \%$ & $8.5 \%$ \\
\hline $\begin{array}{l}\text { Predominant } \\
\text { Depositional } \\
\text { Mechanism }\end{array}$ & $\mathrm{N} / \mathrm{A} *$ & $\begin{array}{l}\text { Effervescence \& } \\
\text { Immiscibility }\end{array}$ & Immiscibility & Temperature & Immiscibility & Fluid Mixing & & & Effervescence & Temperature \\
\hline
\end{tabular}

* Post depositional modification of samples indicates that this area has undergone a later disruption, affecting the reliability of these fluid inclusions

戸 


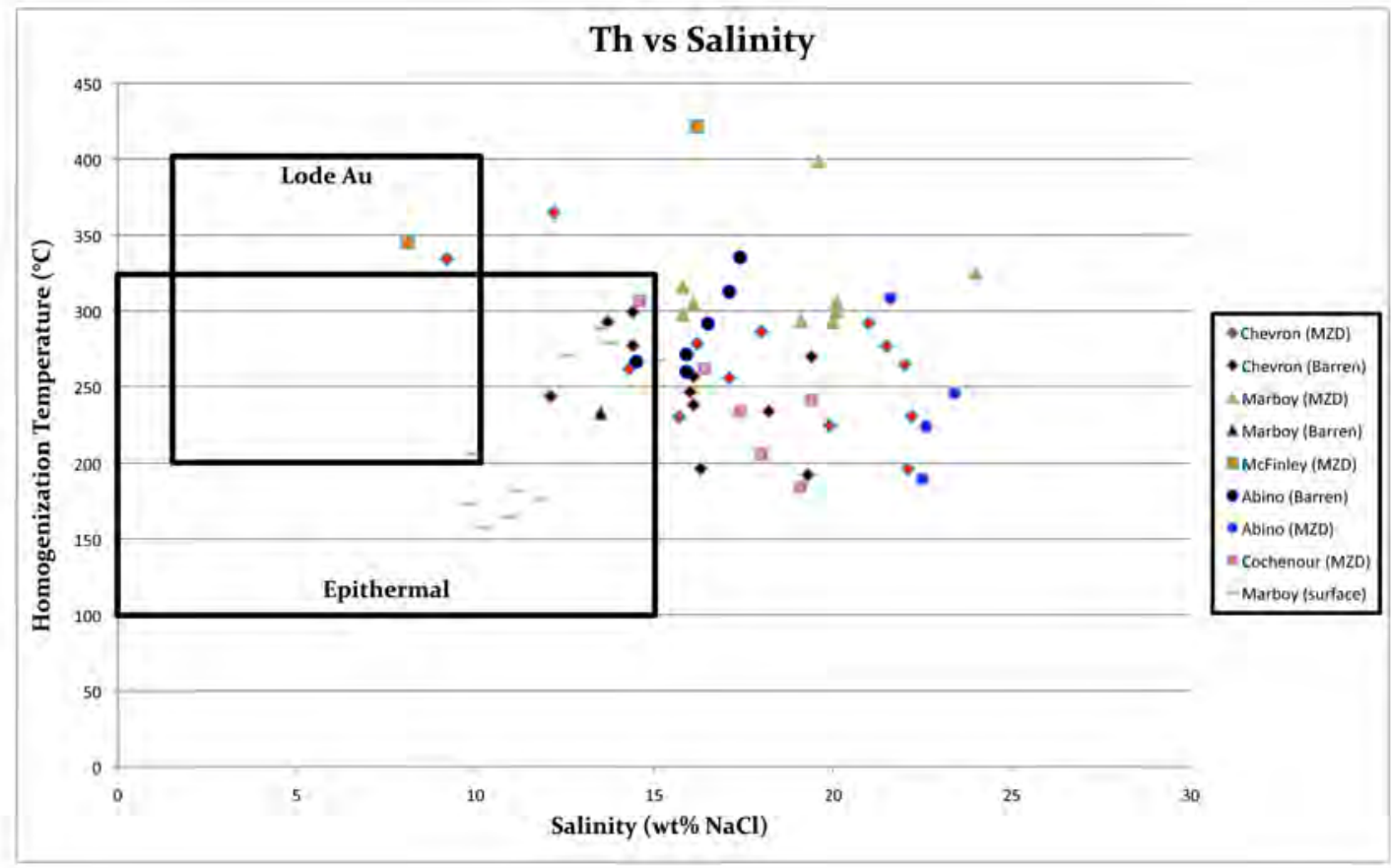

Figure 5.1 - Homogenization temperatures and salinities of samples from the EBT. Black boxes indicate the typical homogenization temperature and salinity fields for epithermal and mesothermal lode gold (ranges from Wilkinson, 2001).

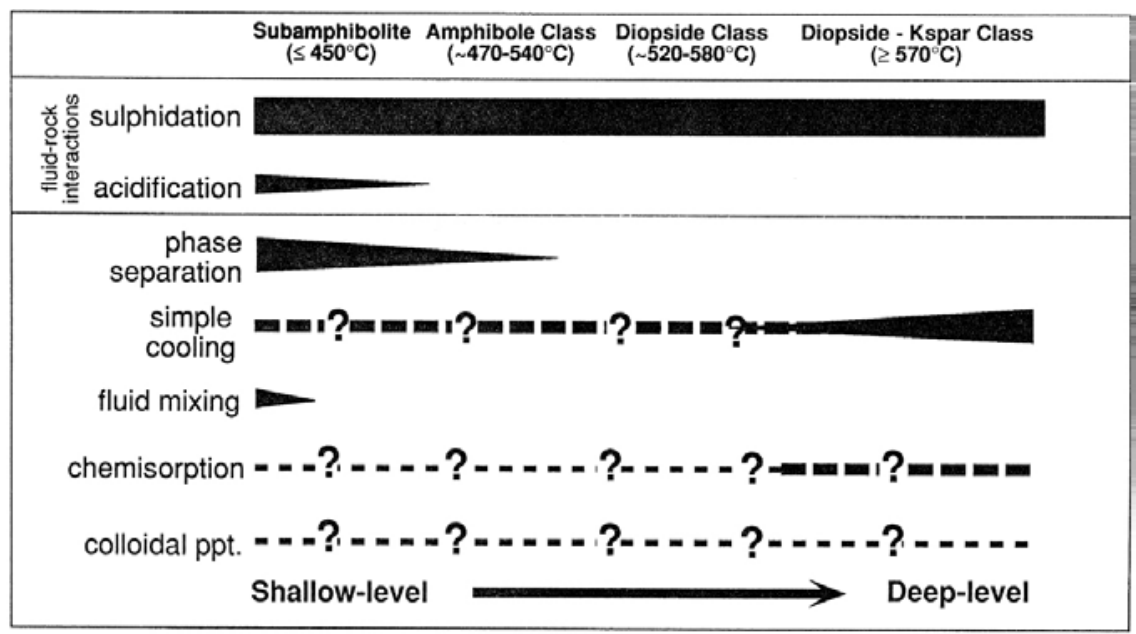

Deposit classes are those of Ridley et al. (1995)

Figure 5.2 - Relative importance of ore depositional mechanisms for different Archean lode-gold deposit classes. Line thickness represents relative importance of the mechanism. Dashed lines indicate potentially important precipitation mechanisms whereas question marks indicate possible or uncertain significance (Mikucki, 1998) 


\section{3 - Carbonate Veins $\left(\right.$ Syn- $D_{1}$ to post- $\left.D_{1}\right)$}

Carbonate veins appear to have formed throughout the whole deformational history of the RLGB, however, the first significant hydrothermal event in the EB area is represented by an extensive system of barren carbonate veins thought to have developed during the first deformational event. These veins intruded through major structures, developing pathways for later fluid transport and altered the surrounding rock units by adding carbonate (Dubé et al., 2001; Dubé \& Gosselin, 2007). The first deformational event was responsible for the localization of strain along the EB corridor and allowed the widespread carbonate veining and alteration that occurred at greenschist facies (Menard et al., 1999).

The onset of carbonate veining is not well established and is thought to have began by $\sim 2740 \mathrm{Ma}$, possibly syn- $\mathrm{D}_{1}$. Minor carbonate fluid pulses appear to have occurred repeatedly until the final fluid stages in the RLGB at 2690 Ma (Fig. 5.3; Dubé et al, 2004). All later vein types, faults, and shear zones overprint these veins, which precede major gold mineralization. Penczak and Mason $(1997 ; 1999)$ suggested that the textures within carbonate veins represent near surface hydrothermal activity, possibly related to a low suphidation (LS) epizonal system. The presence of carbonate fibres at right angles to the vein wall, indicates that they are open-space-filling extensional veins (Dubé \& Gosselin, 2007).

The early carbonate veins contain ferroan dolomite or ankerite that can destabilize the bisulphide complexes in the later siliceous fluids. The interaction between the ferroan carbonate and siliceous fluids would free gold from the bisulphide complexes in the fluid, allowing the siliceous veins to possess gold within 
an otherwise barren carbonate (Rickard, 1997) The presence of auriferous quartz veins within carbonate is not widespread in the EB area and seems to be localized to the McMarmac/Tuckers Knob region. This association and process is very similar to what has been observed at the Red Lake and Campbell mines (Penczak \& Mason, 1997; Dubé et al., 2002). Late carbonate veins that crosscut the main ore-stage veins is evidence for a minor, late carbonate-rich fluid events, which post-dates the ore (Dubé et al., 2004).

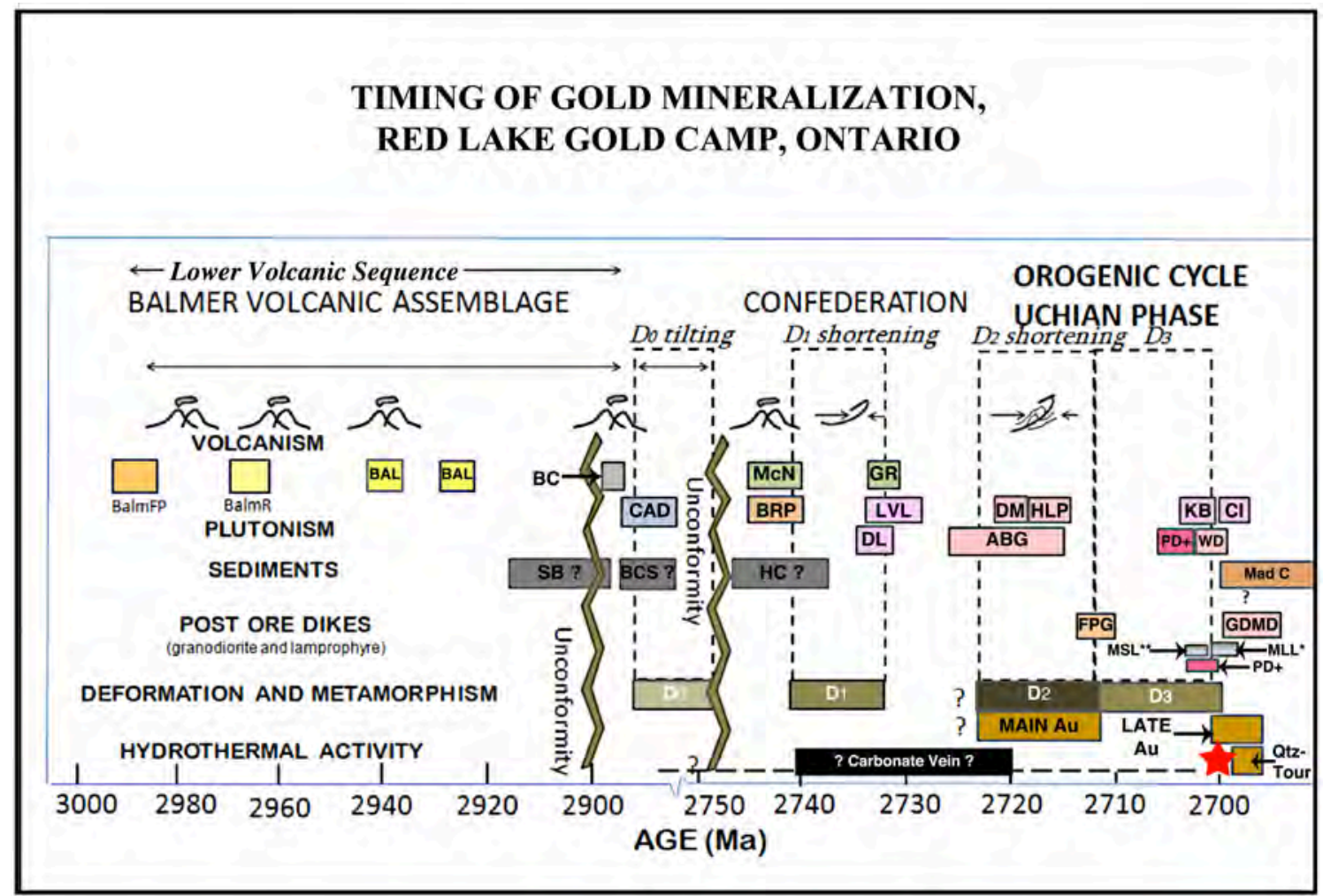

Figure 5.3 - Timing of gold mineralization events in the Red Lake camp. Red star indicates the age of quartz veins from East Bay dated by U-Pb in this study (Modified after Dubé et al., 2004). 


\begin{tabular}{|c|c|c|}
\hline \multicolumn{3}{|c|}{ Timing of Gold Mineralization } \\
\hline CODE & DATE(Ma) & Description \\
\hline ABG & $2720+7 /-5$ & Abino granodiorite \\
\hline Qtz-Tour & & late gold, quartz-tourmaline veins \\
\hline BAL & $\begin{array}{l}2940+/-2 \text { and } \\
2925+/-3\end{array}$ & Ball - Felsic volcanics \\
\hline BalmFP & $2989+/-3$ & Balmer-rhyolite \\
\hline BalmR & $2964+5 /-1$ & Balmer - rhyolite \\
\hline$B C$ & $2894+1-2$ & Bruce Channel volcanoclastics \\
\hline BCS? & 2894 & Bruce Channel sediments \\
\hline BRP & $2742+1-2$ & Brewis Porphyry \\
\hline CAD & $2870+/-15$ & Campbell Dickenson diorite \\
\hline CI & $\begin{array}{l}2699+/-1 \text { and } \\
2697+/-2\end{array}$ & Cat Island pluton \\
\hline DL & $2734+1-2$ & Douglas Lake pluton \\
\hline DM & $2718.2+/-1.1$ & Dome and McKenzie Island stock \\
\hline FPG ${ }^{*}$ & $\begin{array}{l}2712+/-2 \\
2714+/-4\end{array}$ & $\begin{array}{l}\text { Feldspar porphyry granodiorite dykes } \\
\text { Quartz-feldspar porphyry }\end{array}$ \\
\hline GDMD**- & $\begin{array}{l}2698+/-2 \\
2696+/-1\end{array}$ & $\begin{array}{l}\text { granodiorite dyke from Madsen } \\
\text { granodiorite from Creek Zone }\end{array}$ \\
\hline GR & $\begin{array}{l}2732.8 \\
+1.4 / 1.2\end{array}$ & Graves \\
\hline$H C^{*}$ & $\begin{array}{l}<747 \\
2743\end{array}$ & conglomerate \\
\hline HLP & $2717+/-2$ & Hammell Lake pluton \\
\hline ge & $2704+1-1.5$ & Killala-Baird batholith \\
\hline Late-Au & & late-stage gold mineralization \\
\hline LVL & $2731+1-3$ & Little Vermillion batholith \\
\hline MadC & $<2700+1-6$ & English River (Austin tuff) conglomerate \\
\hline Main Au & & main-stage gold mineralization \\
\hline $\mathrm{MCN}$ & $\begin{array}{l}2742+5 /-2 \\
2742+3 /-2\end{array}$ & McNeely volcanics \\
\hline MLE* & $2699+2 /-1$ & shallow dipping melanocratic lamprohyre \\
\hline MSLF" & $2702+/-1$ & mesocratic lamprohyre dykes \\
\hline$P D^{*}$ & $2701+2 /-1$ & pinky granodiorite dyke \\
\hline 58 & 2916 & Slate Bay sediments \\
\hline WD & $2701+/-1.5$ & Wilmar granodiorite dyke \\
\hline
\end{tabular}

Figure 5.3 (continued) - Legend for timing of gold mineralization events in the Red Lake camp

\subsection{1 - Carbon Sources and Isotopic Composition}

The $\delta^{13} \mathrm{C}$ values of all generations of carbonate veins in the EB area $(-2.1$ to $3.7 \% \delta^{13} \mathrm{C}$ ) do not plot in the field of typical barren carbonates from gold systems, such as the ore deposits from the Abitibi belt $\left(\delta^{13} \mathrm{C}\right.$ range of -8.5 to $-2.7 \%$ ) (Fig. 5.4; 
Kerrich et al., 1987). The values from Red Lake carbonates are elevated relative to typical carbonate veins in auriferous systems and their composition remained relatively constant through time, as several generations of veins in different locations along the EB have similar carbon isotopic values. The elevated $\delta^{13} \mathrm{C}$ values are similar to the data reported by El Balili \& Hattori (1998), and Tarnocai (2000) on carbonate samples taken from the eastern RLGB.

\section{Carbonate Isotope Data}

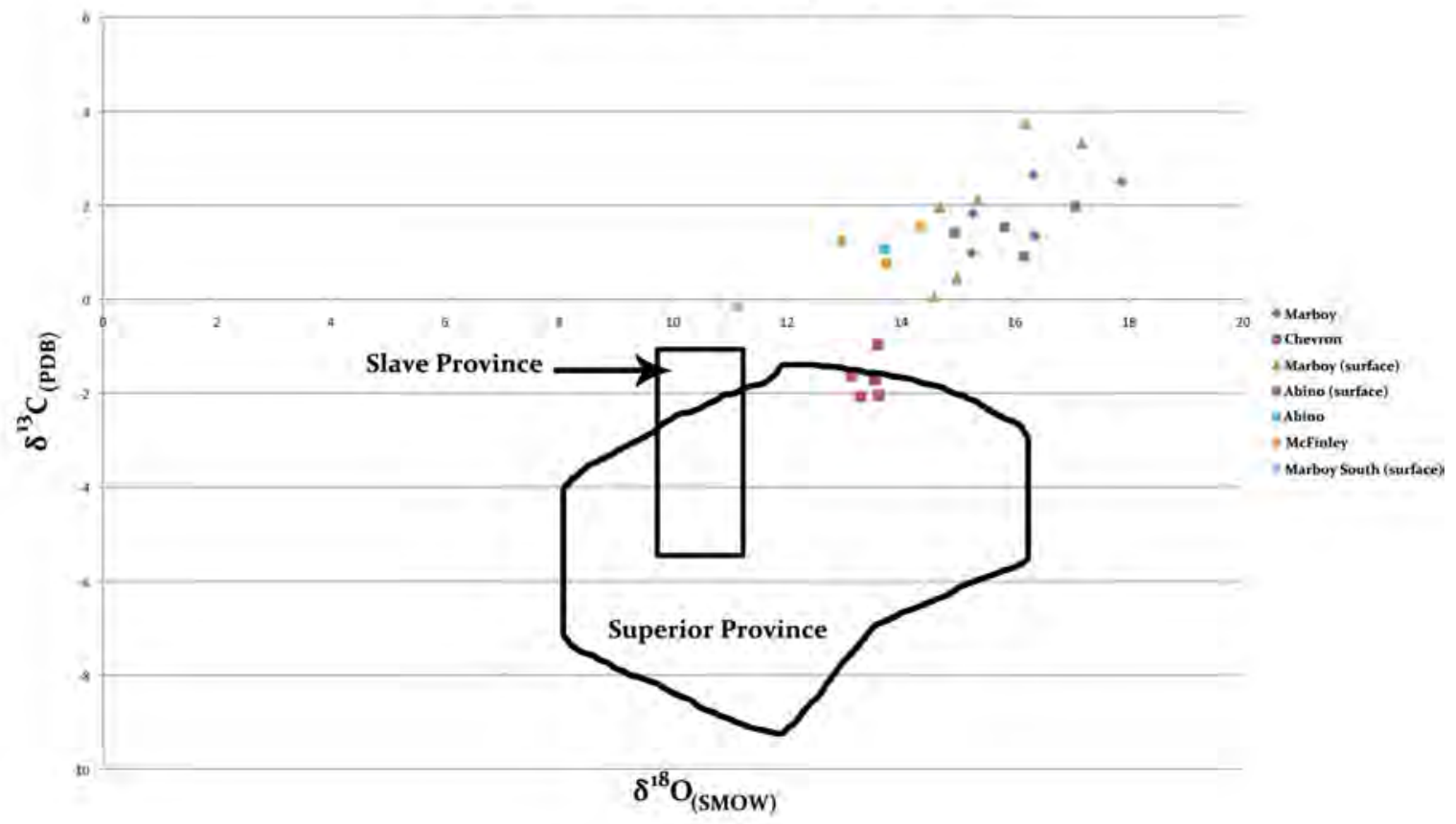

Figure 5.4 - Carbonate isotope values $\left(\delta^{13} \mathrm{C} \& \delta^{18} 0\right)$ from Red Lake relative to values measured from the Superior and Slave provinces (Data modified from Tarnocai, 2000).

The high $\delta^{13} \mathrm{C}$ values of carbonate fluids can be explained by interaction with pre-existing carbonate rocks during the emplacement of the current carbonate veins. The presence of marine carbonates can explain the high $\delta^{13} \mathrm{C}$ values of up to $+4.0 \%$, but it is unlikely as there is no evidence (surface or drill data) of pre- 
existing marine carbonate units throughout the eastern RLGB (Tarnocai, 2000, Sanborn-Barrie et al., 2001).

Temperature, Eh, and $\mathrm{pH}$ are parameters that can affect $\delta^{13} \mathrm{C}$ values during precipitation, as well as the carbon isotope composition of the fluid (Ohmoto \& Rye, 1979). An isotopic shift towards positive values is generally controlled by the degree of reduction that the fluid undergoes during transport. Consequently, the $\delta^{13} \mathrm{C}$ composition will depend on the oxidation of reduced carbon, the degree of dissolution of enriched carbon, and the addition of $\mathrm{CH}_{4}$ to the fluid (Tarnocai, 2000). Methane partitions preferentially into the aqueous fluid due to the partition coefficient between fluid and vapor compared to $\mathrm{CO}_{2}$ and a large $\delta^{13} \mathrm{C}$ fractionation factor that exists between $\mathrm{CO}_{2}$ and $\mathrm{CH}_{4}$. The presence of methane in the fluid causes large positive ${ }^{13} \mathrm{C}$ shifts during vapor phase extraction (Kerrich et al., 1987; Tarnocai, 2000). A possible source for sediments with high $\delta^{13} \mathrm{C}$ values, as well as methane could be the presence with a continental margin accretionary wedge and the organics that are present in such an environment. This study has identified methane within fluid inclusions (Figure 5.5), as do the studies by Tarnocai (2000) and Chi et al., (2003). 


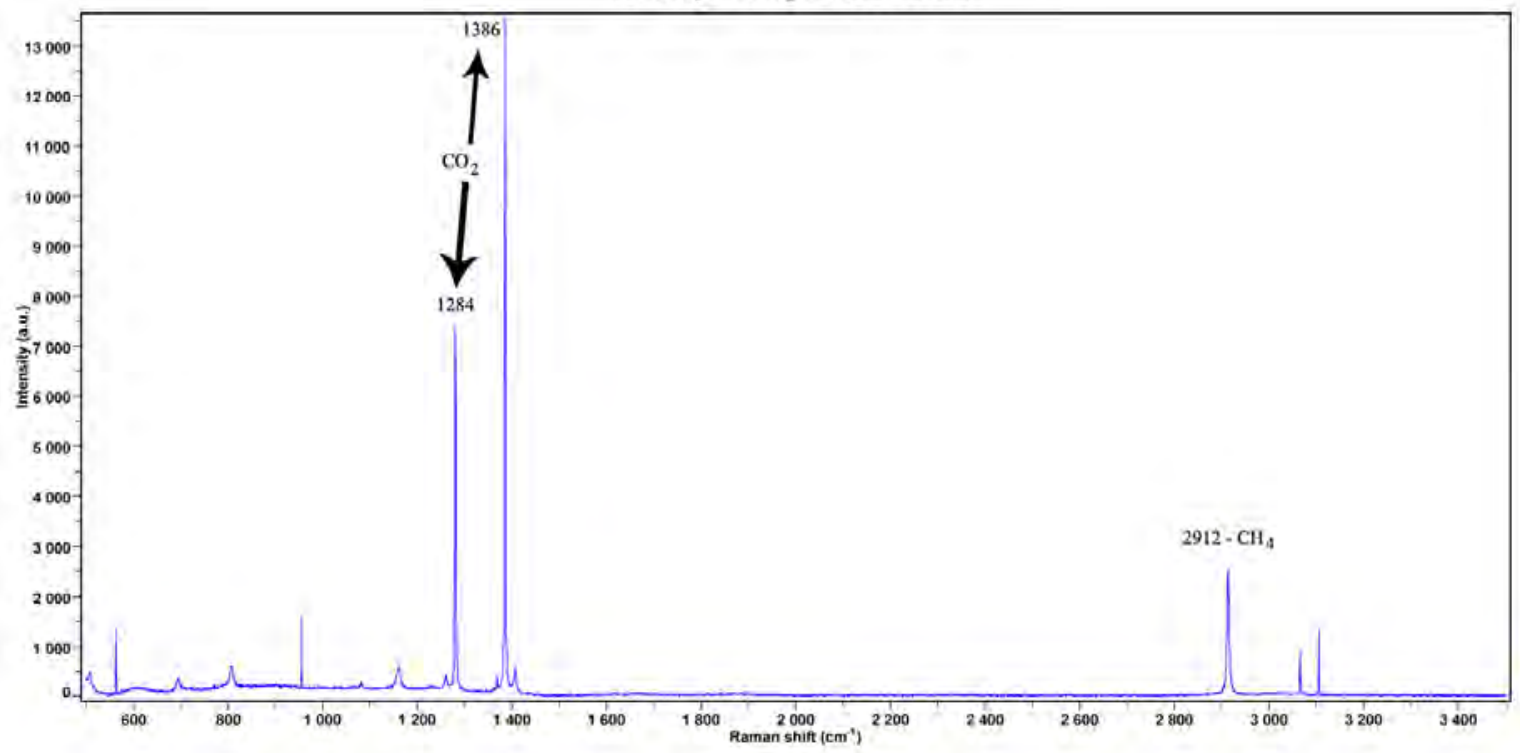

Figure 5.5 - Raman spectrum of the vapor phase of a 15 micrometre, aqueous inclusion in quartz from the Tuckers Knob outcrop, Red Lake, Ontario.

\section{4 - Early Barren Quartz Veins (Post-D 1 )}

The number of fluid events that are responsible for the formation of quartz veins in the EB and the RLGM is difficult to determine due to the similar appearance and composition of most veins. The introduction of gold is associated with later synore siliceous fluid events (also referred to as quartz flooding events) that are related to $\mathrm{D}_{2}$ (after $\sim 2720 \mathrm{Ma}$ ).

A series of siliceous fluids emplaced along major fault/shear structures associated with $\mathrm{D}_{1}$ deformation, some of the same major pathways established by early carbonate veins. The abundance and similarity between quartz-veining events makes it difficult to determine the relative timing of each fluid. For example, Dilworth (2000) identified >15 auriferous vein types at the Campbell mine. The 
early pre-ore stage siliceous veins are barren with the ore-stage fluid events occurring later, between 2720 and 2710 Ma.

\section{5 - Ore-Stage Quartz Veins $\left(\right.$ Syn- $\left.D_{2}\right)$}

The RLGB reached peak metamorphism during the $\mathrm{D}_{2}$ event (localized amphibolite facies) that includes a series of folds that act as important pathways for fluid movement during the main ore stage events (Menard et al., 1999; Tarnocai, 2000). The high fluid pressure of ore-stage fluids reactivated preexisting pathways and overprinted them with a new vein assemblage and causing silica flooding in surrounding host rocks. Veins that were not reactivated are typically free of gold and do not have later overprinting veins. These later auriferous siliceous fluids allowed the earlier barren veins to become mineralized by infiltrating the early carbonate and quartz veins. This is evidenced by high gold grades associated with finer secondary quartz veins, which occurs at the RLGM as well as the in the EB area (Penzak, 1996). This is also the case for the quartz-carbonate veins, which were barren until they were infiltrated and mineralized by later widespread auriferous silicification events (Penzak, 1996). At Abino, later silicious fluid events formed veins that overprint earlier quartz veins and have extensive sulphide zones, which is similar to the quartz-sulphide replacement veins at the Campbell mine (Dilworth, 2000).

A U-Pb date of $\sim 2704 \pm 60$ Ma on vein hosted titanite (Chapter 4.5 ) indicates these veins formed late in the RLGB. Further dating of vein minerals (titanite, rutile, 
and zircon) or of vein alteration halos (Ar-Ar on muscovite, biotite, and fuchsite) would aid in determining the timing of these fluid events.

\subsection{1 - Oxygen Isotopic Composition of Auriferous Quartz Veins}

Oxygen isotopes provide an ideal way to map geothermal systems depending on the variations in the source, transport, and emplacement of the siliceous hydrothermal fluids (Cathles, 1993). Archean lode gold deposits, such as the Abitibi display uniformity in isotopic values for quartz with a narrow range between 12.5 and $15.0 \% 0$ (Kerrich, 1987). A number of parameters will influence the $\delta^{18} 0$ value of the siliceous fluid, with the foremost control being the $\delta^{18} 0$ value of original source fluid and their temperature. The fluid composition can be modified through 1) exchange reactions with wallrock, 2) precipitation of an oxygen-bearing phase in a closed system, 3) immiscible separation of $\mathrm{CO}_{2}$, and 4) mixing with an isotopically distinct reservoir (Kerrich, 1987).

The quartz vein $\delta^{18} 0$ isotopic data from the EB area range from 0.0 to $13.3 \%$. Oxygen isotope values produce distinct groupings for samples from auriferous and barren veins, with the exception of the results from Abino that produce different values. The $\delta^{18} 0$ values of quartz from barren veins ( 0.0 to $8.5 \%$ ) are distinctly lower than in mineralized veins (9.6 to 13.1\%o) (Fig. 5.6). The barren veins from Abino have an elevated $\delta^{18} 0$ value compared to the mineralized sample and is likely due to the post depositional modification (Kontak, 2011). This late alteration/deformation of the area could account for the different $\delta^{18} 0$ values between mineralized and barren samples of quartz from Abino, relative to other 
regions of the EBT and may affect a larger area than Abino. An event this large would have affected all the veins present at Abino and may have affected the surrounding area.

The difference in isotope values between barren and auriferous veins can be attributed to several factors, but the most likely is the variation of fluid-rock ratios. Fluctuating fluid-rock ratios, a change in fluid composition at constant temperature or mixing between two or more isotopically distinct fluids can account for distinctive changes in isotopic values for quartz (Saunders et al., 2008). Another possibility is a change in temperature as fluids emplaced, which would allow for a different degree of isotope fractionation for each respective fluid (Goldfarb et al., 1991). Homogenization temperatures suggest a small temperature difference ( $\sim 50$ $75^{\circ} \mathrm{C}$ ) between barren and auriferous veins, making this an unlikely factor and would require isotope thermometry to confirm true temperatures of veins.

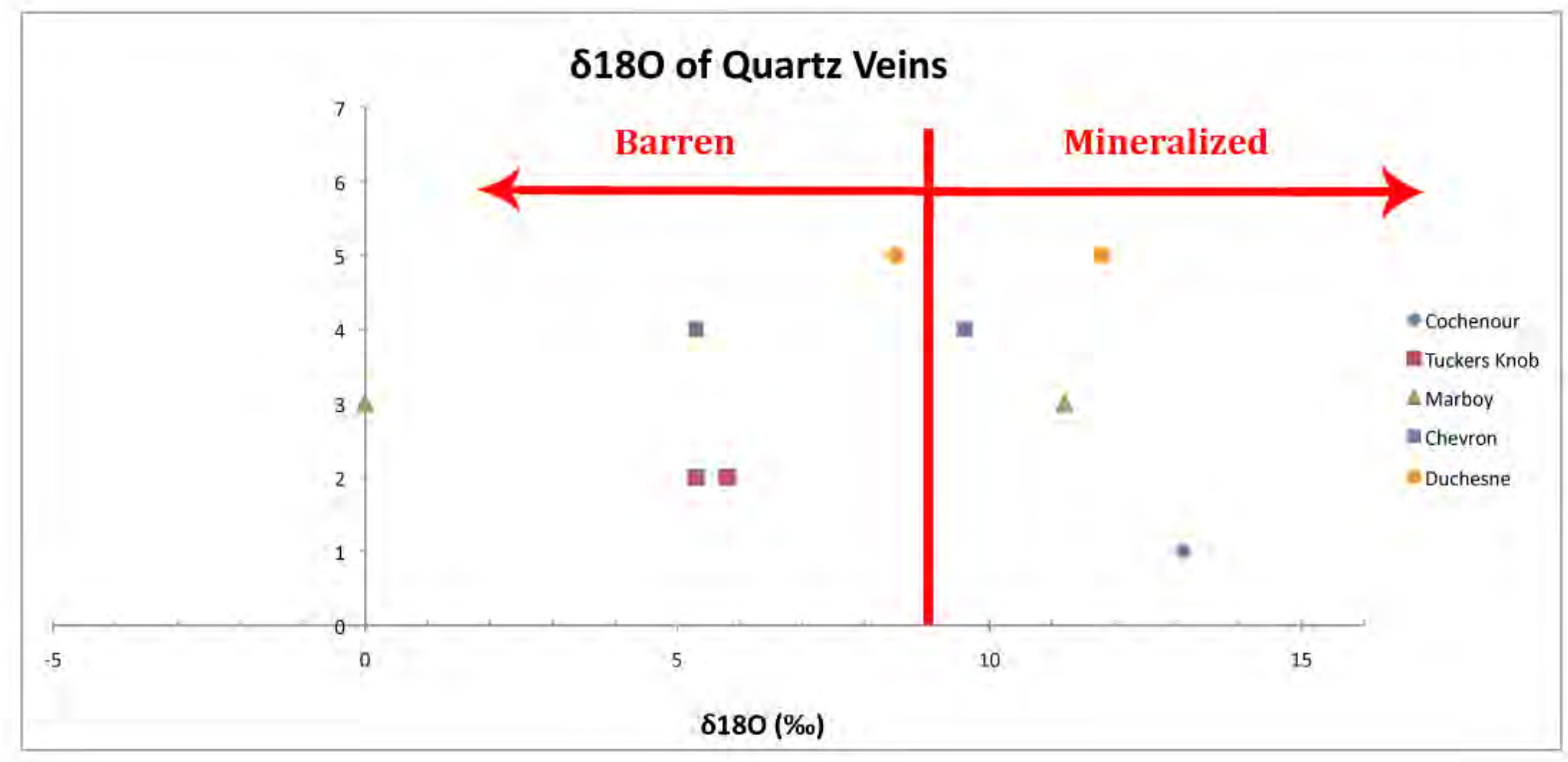

Figure 5.6 - $\delta^{18} 0$ values of quartz from auriferous and barren veins from the EB area showing distinct isotopic fields for different quartz veins. 


\subsection{2 - Source of Sulphur}

The sulphur isotopic composition of hydrothermal system is generally determined by the total sulphur isotope composition of the hydrothermal sulphides, as well as temperature, Eh and $\mathrm{pH}$ (Ohmoto \& Rye, 1979). The source of sulphur is an important question that can indicate the source rocks and how a fluid has interacted with the surrounding rocks. For Archean hydrothermal gold deposits the magmatic system is the largest and most common origin. Sulphur may be derived from 1) direct input from magmatic fluids, 2) leaching or desulphidation of minerals in igneous rocks, and 3) leaching or desulphidation of sulphide minerals from hydrothermal or clastic sediments (Kerrich, 1987). A sedimentary source for sulphur in the EB area is unlikely, due to the lack of sediments present in the RLGB.

Sulphides are common throughout the EBT and are locally abundant, such as at Abino or McFinley. Pyrite is the dominant sulphide in the RLGB and is identified in all deposits. The $\delta^{34} \mathrm{~S}$ values of pyrite range from 2.2 to $5.3 \%$ (Fig 5.7). These data plot within the range of magmatic sulphur values and are similar to $\delta^{34} S$ values obtained from suphides associated with typical orogenic gold deposits (Seal, 2006). Some pyrite grains are isotopically variable; sample MB891-5 has a $2.5 \%$ shift across the grain, from $2 \%$ to $5.5 \%$. This variation may indicate evolution (crystal fractionation) or mixing of fluids to produce significant variability in sulphur isotopes. Later fluids with elevated $\delta^{34} S$ may relate to intruding fluids contaminated by diagenetic sulphides that are present in the host rocks (Kesler et al., 2005).

Sulphides associated with Archean orogenic gold deposits typically have $\delta^{34} S$ values between 0 and 9\%o (Seal, 2006). The relatively narrow range of 
$\delta^{34} \mathrm{~S}$ values indicates that the fluid redox state was below the $\mathrm{SO}_{2} / \mathrm{H}_{2} \mathrm{~S}$ boundary (Kerrich, 1987). Figure 5.8 shows the $\delta^{34} \mathrm{~S}$ values of sulphides from Red Lake relative to other Archean gold deposits.

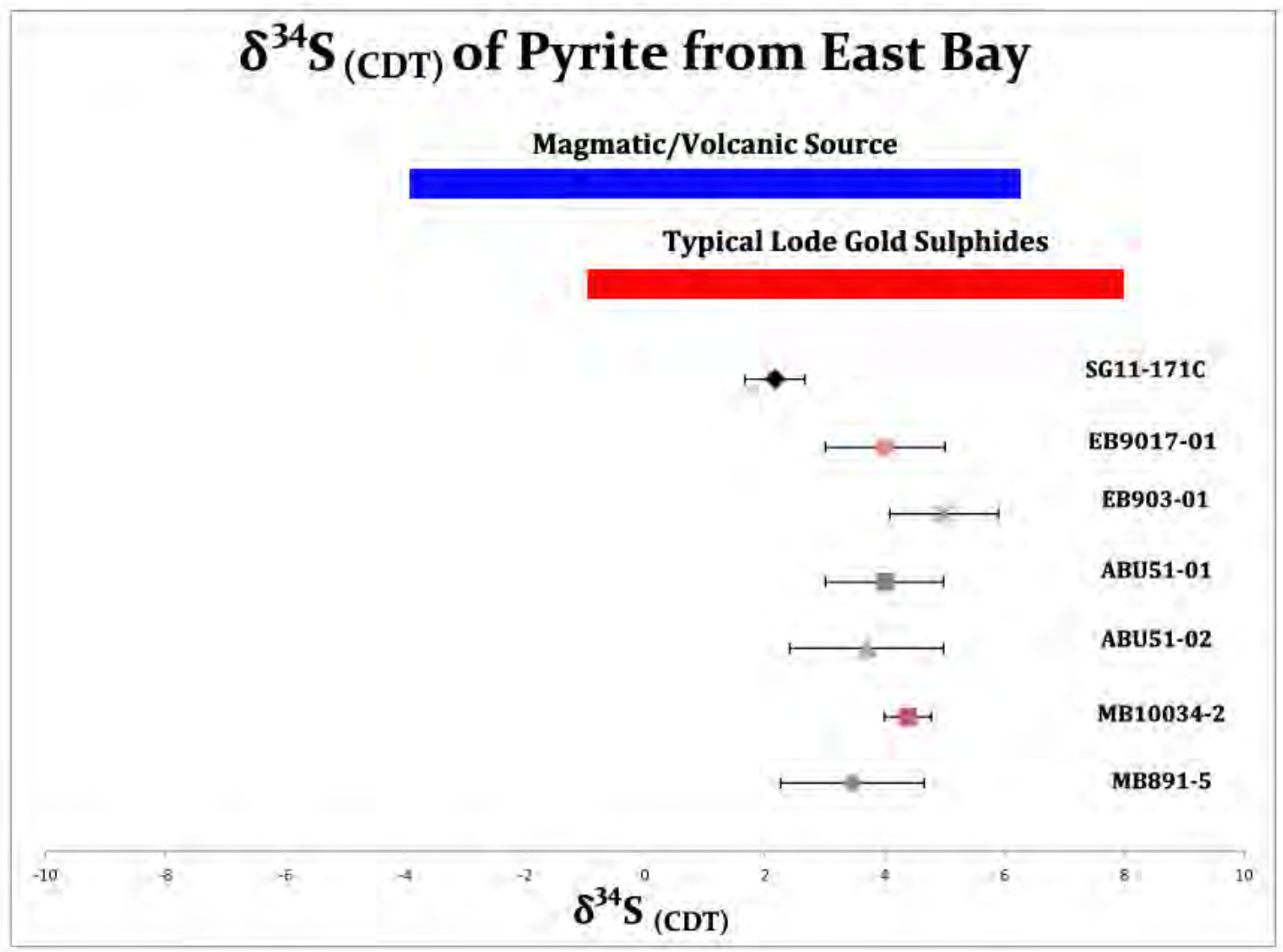

Figure $5.7-\delta^{34}$ S values of sulphides from veins in the EB area. In addition, the known ranges of sulphur from magmatic and hydrothermal veins associated with lode gold deposits (sulphur ranges from Kerrich, 1987; Seal, 2006) 


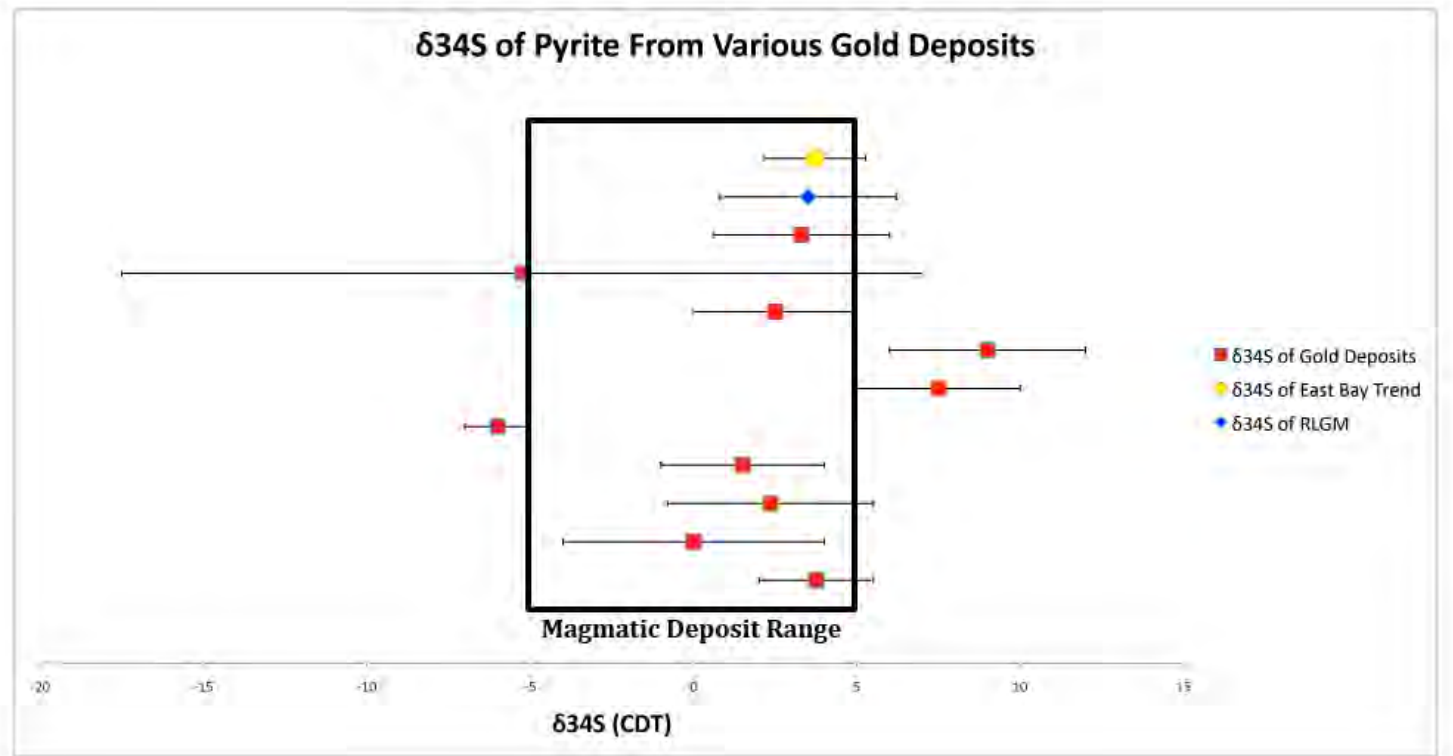

Figure 5.8 - $\delta^{34} \mathrm{~S}$ values for East Bay pyrite (yellow) and $\delta^{34} \mathrm{~S}$ values from the RLGM (Blue; Lavigne \& Crocket, 1982) compared to known values of sulphur from other major gold deposits using pyrite to determine $\delta^{34}$ S. Range of magmatic sulphur indicated by black box (magmatic sulphur range from Kerrich et al., 1987; Seal, 2006)

\section{6 - Post Ore Veins (Syn- $D_{3}$ to Post- $\left.D_{3}\right)$}

The quartz-actinolite and quartz-tourmaline veins represent some of the latest fluid events in the EB area and are possibly associated with $\mathrm{D}_{3}$ between 2700 and 2690 Ma (Penzak, 1996; Dubé et al., 2004). Both of these vein types are auriferous, with the quartz-actinolite veins occurring as the main ore in the Cochenour/Bruce Channel deposit area. $\mathrm{D}_{3}$ deformation develops "black line faults" by high-strain zones. Quartz-actinolite veins occur mainly around the Cochenour and Duchesne areas of the EB area. Quartz-tourmaline veins are found at Cochenour, Marboy, Chevron, and Abino. Late (post-2690 Ma), barren quartz-sericite, quartz, and carbonate veins post-date the mineralized quartz-actinolite and quartztourmaline veins (Fig. 5.9). 


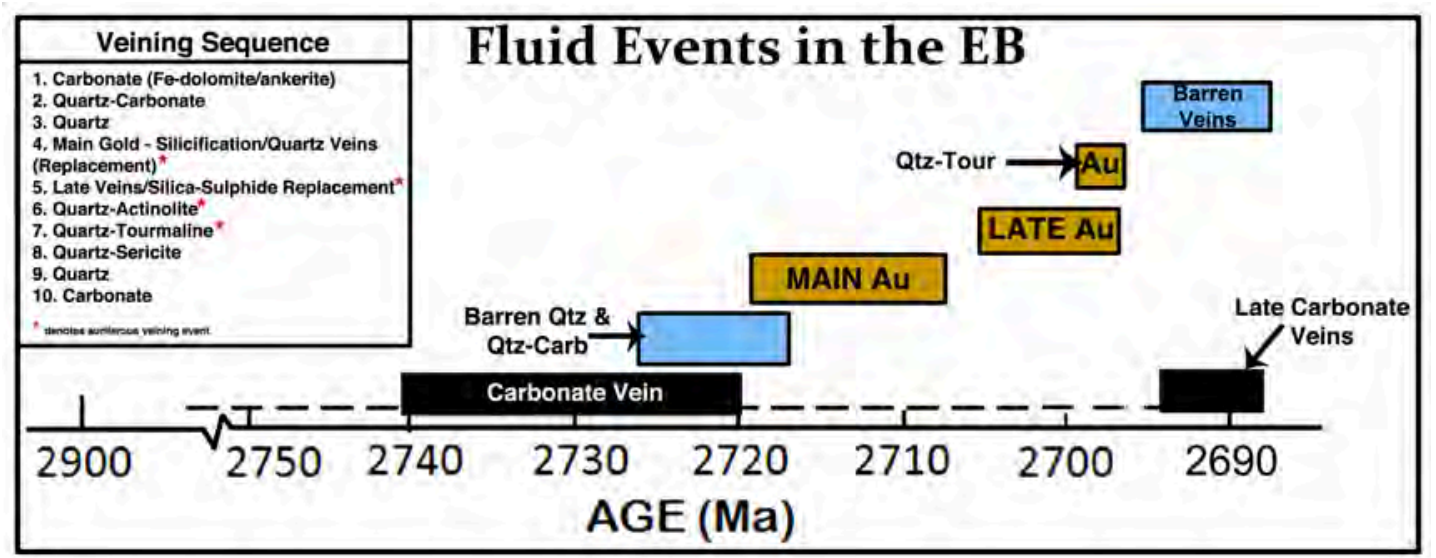

Figure 5.9 - Generalized sequence of veining events identified throughout the EB area. Inset is a list with vein order for the main veining events observed throughout East Bay.

\subsection{1 - Thermometry}

Two quartz-tourmaline veins were analyzed for in-situ oxygen isotopes and yielded temperatures of $219^{\circ} \mathrm{C} \pm 50^{\circ} \mathrm{C}$ for Abino and $222^{\circ} \mathrm{C} \pm 50^{\circ} \mathrm{C}$ for Marboy. These lower temperatures are to be expected because the main ore stage veins were the hottest during peak metamorphism with the greatest hydrothermal activity, whereas the quartz-tourmaline veins occur much later in the tectonic history (Dubé et al., 2004). Auriferous quartz-tourmaline veins from Tuckers Knob display a range of homogenization temperatures between $205^{\circ} \mathrm{C}$ and $285^{\circ} \mathrm{C}$. These values are similar to the measured quartz-tourmaline isotopic equilibrium temperatures of $169^{\circ} \mathrm{C}$ to $272^{\circ} \mathrm{C}$, indicating that the homogenization temperatures from quartztourmaline veins are close to the true temperature and likely do not require any significant pressure correction (Roedder, 1984; Chi et al., 2010). These temperatures suggest that the quartz-tourmaline veins fromed from a separate, lower temperature fluid event (Winter, 2001). 
The measured isotopic composition $\left(\delta^{18} 0\right)$ of two minerals that crystallized in equilibrium from the same fluid are used to calculate temperature and source fluid composition, using equations (5) and (6) (chapter 4.4.3) (O'Neil, 1986; Clayton \& Kieffer, 1991). The $\delta^{18} 0$ values (chapter 4.5.2) of ore fluids that formed quartztourmaline veins are $7.0 \%$ at Marboy and $7.2 \%$ at Abino and indicate that the fluids were derived from an identical source. In addition, Chi et al., (2010) also used quartz-tourmaline pairs from the Buffalo Mine site, north of the town of Red Lake (central RLGB) to determine $\delta^{18} \mathrm{O}_{\text {fluid }}$ values between 5.6 and $7.1 \%$, indicating that

the quartz-tourmaline veins in the central and eastern portions of the belt may have been derived from a similar source.

\section{7 - East Bay Gold Deposits and Genetic Models}

The gold occurrences along the EBT exhibit a variety of characteristics that relate to different gold deposition styles and do not bracket neatly into any one category. The Campbell mine has been classified as a reworked, low-sulphidation epizonal deposit by Penzak \& Mason (1997) and Dubé \& Gosselin (2007). To determine the types of gold deposits that formed along the EBT, it is important to compare characteristics of these deposits with those of the Campbell mine and typical orogenic gold deposits. The gold mineralized zones in the EB area that display similar characteristics to the Campbell mine low-sulphidation epizonal deposit are listed below and summarized in (Table 5.3): 
- Mineralization is overprinted by penetrative fabrics and alteration

- Carbonate veins with late siliceous infill produces internal textures that form oblique to vein margins (typical extensional features)

- Hydrothermal breccias (particularly in the carbonate)

- Sheeted veinlet zones occur in several localities

- 'Snowbank' veins form in dilatant zones

- Siliceous replacement zones overprinting veins and surrounding host rocks

- Metallic associations of ore in some vein types with an epizonal signature $(\mathrm{Au}, \mathrm{Ag}, \mathrm{As}, \mathrm{Sb}, \mathrm{Zn}$, etc.)

- Fluid salinity ranges between $9-20 \mathrm{wt} \% \mathrm{NaCl}$

Several features exist that don't fit the low-sulphidation epizonal regime, and all the characteristics of Red Lake deposits, including the EB showings, don't fit into a typical genetic model. It is more likely that the various deposits that occur in Red Lake evolved over many stages with typical mesozonal characteristics (MacGeehan and Hodgson, 1982). The crustal level of the RLGB is still changing at this time, allowing for significant changes to the tectonic regime throughout the duration of hydrothermal activity (Groves et al., 1998). Several lines of evidence support a mesozonal origin for the EB showings. These are:

- Greenstone-hosted quartz-carbonate veins throughout the RLGB

- Compressional regime causing intense folding of units from $D_{2} \& D_{3}$

- Deposits are laterally extensive and vertically uniform (epizonal deposits 
are narrow and vertically zoned).

- Spatial association with fault zones and granitic belts

- Ag:Au ratio of $\sim 1: 10$ (low sulphidation epizonal have ratios that are $>1: 1$ and high sulphidation exceeding 100:1; Taylor, 2007)

- Homogenization temperatures in quartz veins from EB area are 200$350^{\circ} \mathrm{C}$

- $\delta^{18} \mathrm{O}_{\text {quartz }}$ values are $9.6-13.1 \%$ for auriferous veins (higher temperature) and $\delta^{18} \mathrm{O}_{\text {quartz }}$ is $17.2-17.3 \%$ for late quartz-tourmaline veins (lower temperature).

- $\delta^{18} \mathrm{O}_{\text {water }}$ values are $\sim 7 \%$ for the source fluid indicating possible magmatic, metamorphic, or meteoric source fluids, however $\delta \mathrm{D}$ is required to accurately determine the source.

- Fluid pressures from the Campbell Mine (maximum 3.7 kbars; Tarnocai, 2000) are greater than in an epizonal setting suggesting a likely crustal depth of $4-8 \mathrm{~km}$

Sanborn-Barrie et al. (2001) suggests extensional and compressional features throughout the Red Lake belt and represents a series of accreted terranes in an arc setting. This tectonic scenario accounts for a structurally complex system that shows characteristics of low-sulphidation epizonal deposits, as well as those of mesozonal orogenic deposits (Groves et al., 1998). Figure 5.11 shows the complexity of these deposits and how there is some degree of overlap between the models at certain similar levels. 


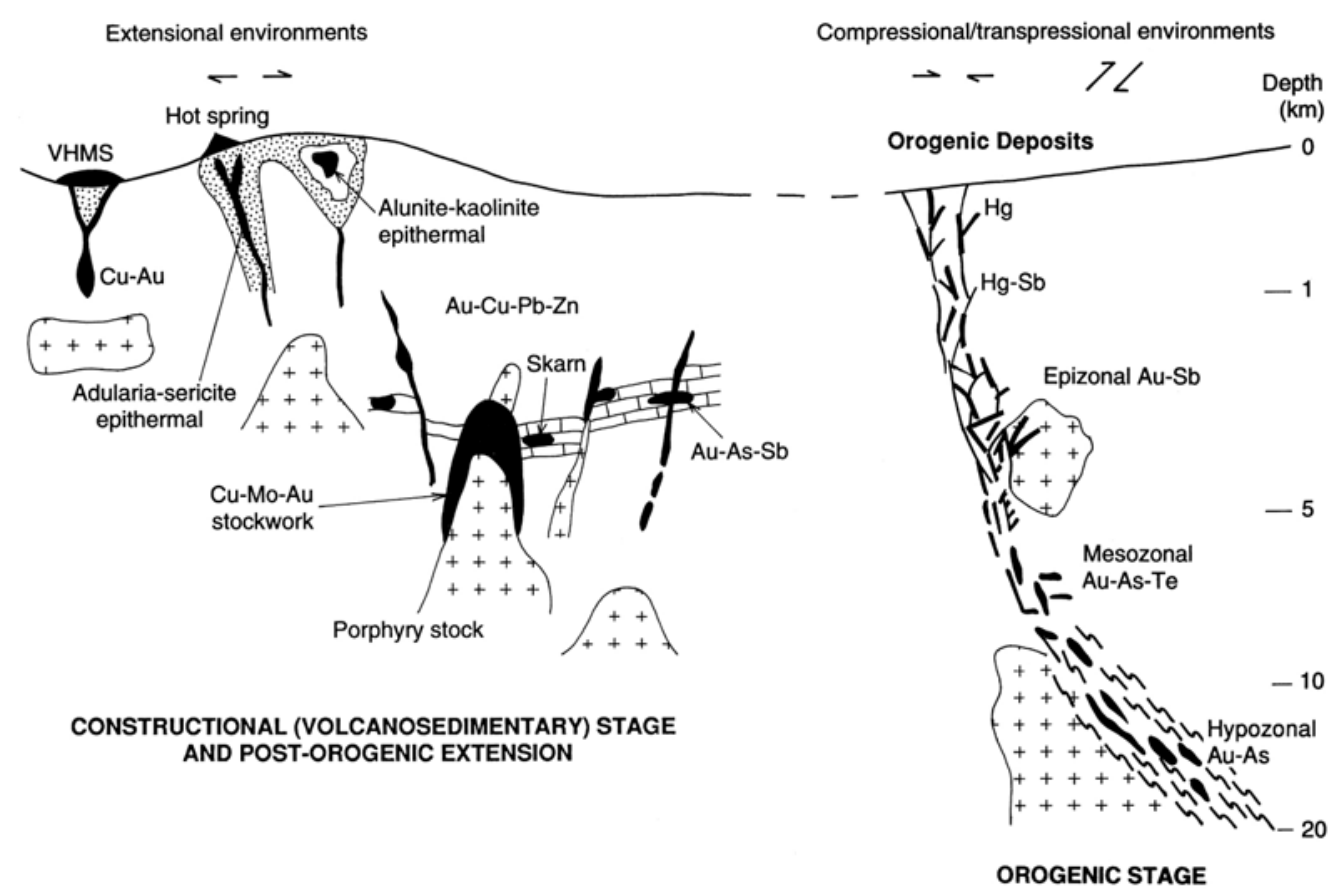

Figure 5.10 - Schematic representation of crustal environments for hydrothermal gold deposits in terms of depth and structural setting within convergent plate margins. Not all deposits can be explained by a single part of this figure, but may require the combination of events (after Groves et al., 1998)

Three possible genetic models for the formation of the deposits along the EBT (and also the RLGM).

1. The first scenario is an Archean low-sulphidation epizonal model that was deformed and metamorphosed (Table 5.2; Poulsen, 2000). If the deposit was formed prior to peak metamorphism, later hydrothermal fluids would have overprinted the earlier quartz leaving the primary fluid inclusions from the later fluid event, rather than the mineralizing events. The use of geobarometry would not give accurate estimates of peak metamorphic 
conditions. The $\delta^{18} 0$ values of auriferous quartz veins exceed the typical range for epizonal deposits and overlap the isotopic range between typical epizonal and mesozonal quartz, with the quartz-tourmaline veins having even higher $\delta^{18} \mathrm{O}$ values. This model is similar to the one proposed by Penczak and Mason (1997) for the nearby Campbell Mine.

2. The second scenario involves early carbonate veining stage from a compressional environment $\left(D_{1}\right)$ allowing for large parallel structures that develop carbonate-filled veins and associated textures from high pressure fluids. This would occur at greenschist facies $\left(\mathrm{M}_{1}\right)$ and is followed by a subsequent extensional stage $\left(D_{2}\right)$. Amphibolite facies metamorphism facilitated the development of a typical orogenic mesozonal deposit (syn- to post-peak metamorphism) similar to those described by Dubé and Gosselin (2007). Some of these veins along with faults and shear zones provide pathways for the later mesozonal fluids to intrude. As the numerous pulses of fluid moved through the Red Lake region, favorable depositional mechanisms would have to occur, allowing the gold to concentrate along these primary and secondary structures. This model however cannot account for the characteristically epizonal metallic concentrations found at the Campbell Mine, nor does it explain fluid salinities $>10 \mathrm{wt} . \% \mathrm{NaCl}$.

3. The third scenario is a multi-stage model that straddles the boundary between the epizonal and mesozonal regimes (equates to a crustal depth of 
$\sim 5-6 \mathrm{~km}$ ). This crustal level shifts as a consequence of tectonism with time, where increased burial shifts from the lower epizonal system into the upper mesozonal regime. This is similar to the model proposed by McGeehan \& Hodgson (1982). Early extension accounts for carbonate veining and would develop early fluid pathways. This would have been at a higher crustal level allowing for the development of typical shallow breccia carbonates and some of the early breccia quartz. As the development of the belt progressed, the mesozonal fluids (main ore events) were emplaced along regional structures. As these metamorphic fluids evolved, a magmatic component was introduced (secondary lesser gold event) from the nearby intruding granitic bodies creating a mixed fluid. This would account for increased fluid salinity (porphyry fluids can have salinities $>60 \mathrm{wt} \% \mathrm{NaCl}$; Wilkinson, 2001) and can explain changes in the metal concentrations. Pervasive siliceous events also occur near these late intrusions, indicating the presence of a late deuteric fluid. Fluid inclusion characteristics and geothermometry indicate the fluid was likely not near surface, but probably at moderate depths. 
Table 5.2 - Characteristics of known gold deposit styles. Orogenic lode gold and epithermal deposits are within the red box, as they are the most likely classifications for the East Bay deposits and the Campbell Mine (after Groves et al., 1998).

\begin{tabular}{|c|c|c|c|c|c|c|c|c|}
\hline $\begin{array}{l}\text { Deposit } \\
\text { type }\end{array}$ & Examples & Tectonic setting & $\begin{array}{l}\text { Temp. of } \\
\text { formation } \\
\left({ }^{\circ} \mathrm{C}\right)\end{array}$ & $\begin{array}{l}\text { Depth of } \\
\text { emplacement } \\
\text { (km) }\end{array}$ & $\begin{array}{l}\text { Ore fluid } \\
\text { composition }\end{array}$ & Au:Ag & Alteration types & Other key features \\
\hline Orogenic & $\begin{array}{l}\text { Kalgoorlie (Australia). } \\
\text { Val d'Or (Canada). } \\
\text { Ashanti (Ghana). } \\
\text { Mother lode (USA) }\end{array}$ & $\begin{array}{l}\text { continental margin: } \\
\text { compressional to } \\
\text { Iranspressional } \\
\text { regime; veins typically in } \\
\text { metamorphic rocks on } \\
\text { seaward side of } \\
\text { continental are }\end{array}$ & $200-700$ & $2-20$ & $\begin{array}{l}3-10 \text { eq. } \mathrm{wt} \% \\
\mathrm{NaCl}, \geq 5 \\
\mathrm{~mol} / \mathrm{CO} \mathrm{CO}_{2} \\
\text { traces of } \mathrm{CH}_{4} \\
\text { and } \mathrm{N}_{2}\end{array}$ & $1-10$ & $\begin{array}{l}\text { carbonation. } \\
\text { sericitization, } \\
\text { sulfidation; skatn- } \\
\text { like assemblages in } \\
\text { higher temperature } \\
\text { deposits }\end{array}$ & $\begin{array}{l}\text { hosted in deformed metamorphic } \\
\text { terranes; } \leq 3-5 \% \text { sulfide } \\
\text { minerals: individual deposits of } \\
\geq 1-2 \mathrm{~km} \text { vertical extent; spatial } \\
\text { association with transerustal fauti } \\
\text { zones and granitic magmatism }\end{array}$ \\
\hline $\begin{array}{l}\text { Epithermal } \\
\text { (low snd high } \\
\text { sulfidation) }\end{array}$ & $\begin{array}{l}\text { high sulf, - Goldfield } \\
\text { (USA), Stenimitville } \\
\text { (USA), Julcani (Peru), } \\
\text { Lepanto (Plitippines): } \\
\text { low sulf: = Comstóck } \\
\text { Lode (USA). Fresnillo } \\
\text { (Mexico), Golden } \\
\text { Cross (New Zealand) }\end{array}$ & $\begin{array}{l}\text { oceanic arc, continental } \\
\text { arc, or back are } \\
\text { extension of continentat } \\
\text { crust: extensional } \\
\text { environments normal. } \\
\text { but commonly in } \\
\text { compressional regimes }\end{array}$ & $100-300$ & $\begin{array}{l}\text { surface- } \\
2 \mathrm{~km}\end{array}$ & $\begin{array}{l}\angle \mathrm{I}-20 \text { eq wroh } \\
\mathrm{NaCl} \\
\text { early acidic } \\
\text { condensate (thigh } \\
\text { sulf.) }\end{array}$ & $0.02-1$ & $\begin{array}{l}\text { adufaria-sericite- } \\
\text { quartz (low sulf,) } \\
\text { versus quartz-alumite- } \\
\text { kaotinite (tight } \\
\text { sulf) }\end{array}$ & $\begin{array}{l}\text { veins and reptacements are simifiar } \\
\text { gege as ore-hosting or nearby } \\
\text { yolcanic rocks; ore zones } \\
\text { generally } 100-500 \text { m in verticul } \\
\text { extent; dissenunated ore comimon } \\
\text { in high sulf. systems }\end{array}$ \\
\hline $\begin{array}{l}\text { Epithermal } \\
\text { (alkalic- } \\
\text { related) }\end{array}$ & $\begin{array}{l}\text { Cripple Creek (USA); } \\
\text { Porgera (PNG): } \\
\text { Emperot, Fiji }\end{array}$ & $\begin{array}{l}\text { post-subduction. back } \\
\text { arc extension; extension } \\
\text { can be adjacent to } \\
\text { magmatic arc or } \\
\text { bundreds of } \mathrm{km} \\
\text { landward }\end{array}$ & $\begin{array}{l}\text { generaliy } \\
5200\end{array}$ & $\begin{array}{l}\text { surface- } \\
2 \mathrm{~km}\end{array}$ & $\begin{array}{l}\leq 10 \text { eq. } \mathrm{wt}^{2} \\
\mathrm{NaCl} \text { high } \mathrm{CO}_{2}: \\
\text { taces of } \mathrm{CH}_{4} \text { atd } \\
\mathrm{N}_{2}\end{array}$ & $\begin{array}{l}\text { very } \\
\text { variable }\end{array}$ & $\begin{array}{l}\text { carbonation, } \mathrm{K} \text { - } \\
\text { metasomatism. } \\
\text { propylitic } \\
\text { assemblages }\end{array}$ & $\begin{array}{l}\text { Te-rich deposits associated with } \\
\text { alkalic igneous rocks: ores } \\
\text { commonly in breccia pipes and as } \\
\text { manto-type replacements }\end{array}$ \\
\hline $\begin{array}{l}\text { Sedimentiary- } \\
\text { rock hosted }\end{array}$ & $\begin{array}{l}\text { Cartiin (USA). Jerritt } \\
\text { Canyon (USA). } \\
\text { Guizhou (PR China) }\end{array}$ & $\begin{array}{l}\text { back-arc estension and } \\
\text { thinning of continentsil } \\
\text { crust }\end{array}$ & $200-300$ & $2-3$ & $\begin{array}{l}\leq 7 \text { eq. wto } \\
\text { NaCl: }\end{array}$ & $0.1-10$ & $\begin{array}{l}\text { intense } \\
\text { silicification: some } \\
\text { katinization }\end{array}$ & $\begin{array}{l}\text { very fine-grained gold in intensely } \\
\text { silicified rock; dissolution of } \\
\text { surrouading carbonate }\end{array}$ \\
\hline $\begin{array}{l}\text { Gold-rich } \\
\text { porpliyry }\end{array}$ & $\begin{array}{l}\text { Binghaum (USA), } \\
\text { Grasberg (tndonesia), } \\
\text { Lepanto-Far Southeast } \\
\text { (Philippines), } \\
\text { Kingking (Philippines) }\end{array}$ & $\begin{array}{l}\text { oceanic or contineutal } \\
\text { arc; subduction-related } \\
\text { but often associated } \\
\text { with extensional } \\
\text { environments }\end{array}$ & $300-700$ & $2-5$ & $\begin{array}{l}\text { some fluids }>35 \\
\text { eq. wt } \\
\text { NaCl; can mix } \\
\text { with low salinity } \\
\text { surface waters: } \\
\text { often immiscible } \\
\text { vapor }\end{array}$ & $0.001-0.1$ & $\begin{array}{l}\text { central biotite-KF } \\
\text { zone surrounded } \\
\text { by quartz-chlorite: } \\
\text { common sericite- } \\
\text { pyrite overprinting; } \\
\text { distal propylitic } \\
\text { alteration }\end{array}$ & $\begin{array}{l}\text { disseminated sulfides and veinlets } \\
\text { within and adjacent to porphyritic, } \\
\text { silitic- oo intermediate composition } \\
\text { intrusions: low oxidation state of } \\
\text { magnas may favor gold } \\
\text { enrichments; generally F-type } \\
\text { magmas: gold introduced with Cut } \\
\text { sulphides }\end{array}$ \\
\hline $\begin{array}{l}\text { Gold-rich } \\
\text { skarn }\end{array}$ & $\begin{array}{l}\text { Hedley (Canada), } \\
\text { Fonitude (USA). } \\
\text { Crown Jewel (USA) }\end{array}$ & $\begin{array}{l}\text { oceanic or continental } \\
\text { arc; subduction-related } \\
\text { bur often associated } \\
\text { with exlensional } \\
\text { euvviromments }\end{array}$ & $300-600$ & $1-5$ & $\begin{array}{l}10 \text { to }>35 \mathrm{eq} \\
\mathrm{wr} / \mathrm{NaCl}\end{array}$ & $\leq \mathrm{t}-10$ & $\begin{array}{l}\text { garnet-pyroxenc- } \\
\text { epidote-chlorite- } \\
\text { calcite }\end{array}$ & $\begin{array}{l}\text { most occur as calcic exoskarns; } \\
\text { typically associated with mafic. } \\
\text { low-silica, very reduced plutoos }\end{array}$ \\
\hline $\begin{array}{l}\text { Submarine } \\
\text { exhlalative }\end{array}$ & $\begin{array}{l}\text { Horne (Canada), } \\
\text { Bousquet (Canada), } \\
\text { Greens Creek (USA). } \\
\text { Botiden (Sweden) }\end{array}$ & $\begin{array}{l}\text { back-are rift basins } \\
\text { (Kuroko-type) or mid- } \\
\text { ocean senfloor } \\
\text { spreading (Cyprus-and } \\
\text { Besshi-type) }\end{array}$ & $\leq 350$ & $\begin{array}{l}\text { on or near } \\
\text { seafloor }\end{array}$ & $\begin{array}{l}3.5-6.5 \mathrm{eq} \\
\text { wit\% NaCl: } \\
\text { much higher } \\
\text { salinities where } \\
\text { Tluid interaction } \\
\text { with brimes. }\end{array}$ & $\begin{array}{l}0.0001- \\
0.1\end{array}$ & $\begin{array}{l}\text { quartz-tale-chlorite } \\
\text { is most common } \\
\text { with an outer zone } \\
\text { of illite } \pm \text { smectite: } \\
\text { antydrite or barite } \\
\text { cap in places }\end{array}$ & $\begin{array}{l}\text { laminated, banded, or massive } \\
\text { fine-grained sulphides; commoniy } \\
\text { both exhalative and } \\
\text { synsedimentary replacement } \\
\text { textures; goid relatively more } \\
\text { important in back-arc regions }\end{array}$ \\
\hline
\end{tabular}




\section{5 - Comparison of the East Bay Trend to the Red lake Gold Mines, and other world-class gold deposits}

The gold showings in the EB area exhibit many similarities with the RLGM deposits (Campbell \& Dickenson mines). A comparison between all gold deposits with $>20,000 \mathrm{oz}$ from Red Lake can be viewed in Table 5.3. Similarities shared between the EBT and RLGM deposits include:

- Veins are structurally controlled

- Aluminous mineral alteration assemblages surround veins

- Balmer Assemblage hosts the deposits (with the exception of the Abino Granodiorite, Chevron Zone, and the McFinley F2 zone).

- Both areas have undergone mid- to upper-greenschist facies metamorphism

- Open-space-filling textures of veins, dilation textures, crustiform banding, and vein breccias are indicative of shallow crustal levels or high fluid pressures.

- The ore fluids are $\mathrm{H}_{2} \mathrm{O}-\mathrm{CO}_{2}-\mathrm{NaCl}$ with $\mathrm{CO}_{2}$ as the dominant phase. The EB area has more aqueous assemblages identified and higher salinity than the RLGM, but this may be due to the location of samples used by Chi et al. $(2003,2006)$ from the RLGM.

- Sulphur isotopes from pyrite indicate a magmatic/volcanic origin of sulphur

- Numerous gold mineralizing events occur in a wide variety of vein styles.

The EBT and RLGM deposits share many similarities with metamorphosed low sulphidation epizonal systems, such as the Campbell Mine (Penczak \& Mason, 
1997). Previous studies (Tarnocai, 2000; Chi et al., 2003) have indicated that the pressure at which these deposits formed falls within the mesozonal range ( $>5-10$ $\mathrm{km}$ ) of deposits within an orogenic system. In addition, veining within these deposits are more typical to the greenstone-hosted quartz-carbonate vein deposit styles.

$\delta^{18} \mathrm{O}$ values of quartz from the EB area compared to $\delta^{18} \mathrm{O}$ values of quartz from typical epizonal and mezozonal deposits (Figure 5.12) shows that the EBT quartz overlaps both epizonal and mesozonal deposit ranges, which suggests a complex fluid history. A comparison with other world-class deposits is displayed below in Table 5.4.

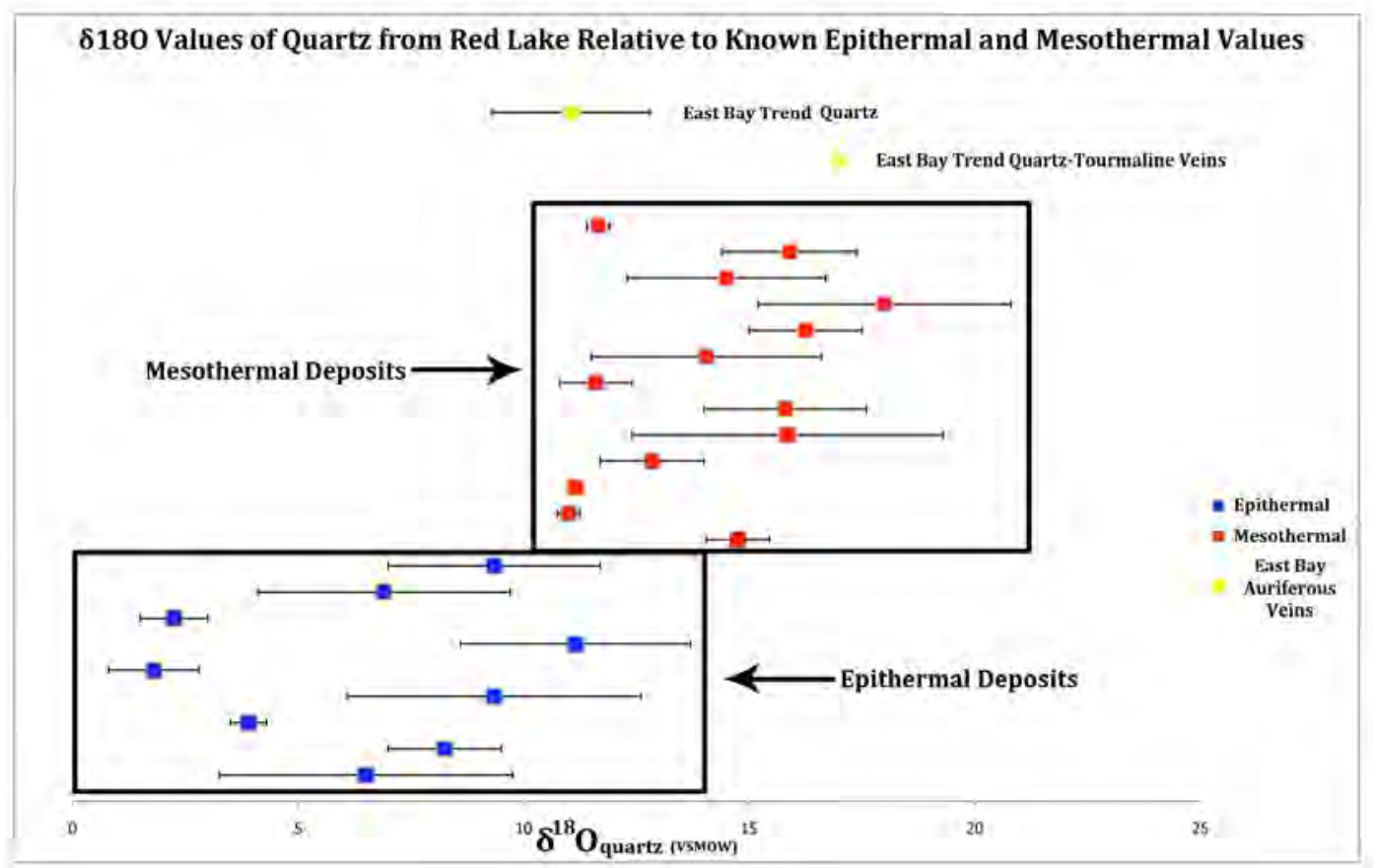

Figure 5.11 - Oxygen isotope range for auriferous quartz from the East Bay Trend compared to well-known epithermal and mesothermal deposits from around the world. 
Table 5.3 - Geological characteristics of $>20000 \mathrm{oz}$ gold deposits in the Red Lake camp with the addition of the generalized East Bay Trend deposits from this study. Madsen and Starratt-Olsen are separate deposits but are similar and are combined for the purposes of this table.

Howey and Hasaga are grouped together since they are similar deposits and are adjoining mines. (Modified after Penczak, 1996)

\begin{tabular}{|c|c|c|c|c|}
\hline DEPOSIT & HOST ROCKS & TYPE OF MINERALIZATION & ORE MINERALOGY & ALTERATION \\
\hline $\begin{array}{l}\text { Campbell-Red Lake } \\
\text { Mine Complex }\end{array}$ & Basalt, Ultramafic Rocks & $\begin{array}{l}\text { Siliceous replacement of brecciated Q-C vein material. } \\
\text { Siliceous replacement of carbonatized, sheared wall-rock. } \\
\text { Fracture-filling dilatent quartz veins. }\end{array}$ & $\begin{array}{l}\text { Po, Py, Aspy, (Mt, Cpy, Sp, } \\
\text { Sch, St, Mb, Ga, VG) }\end{array}$ & $\begin{array}{l}\text { Carbonate, Silicate, Aluminous, Biotite, } \\
\text { Sericite/Fuchsite, Chlorite }\end{array}$ \\
\hline Cochenour Willans & Mafic Volcanics & $\begin{array}{l}\text { Replacement of Q-C fissure fillings. } \\
\text { Occurs in lenses and pipes }\end{array}$ & $\begin{array}{l}\text { Py, Aspy, (Po, Cpy, Sph, St, } \\
\text { Ga, Tet, Ja, VG) }\end{array}$ & $\begin{array}{l}\text { Silicate, Carbonate, Sericite, Aluminous, } \\
\text { Biotite alteration of ultramafic rocks }\end{array}$ \\
\hline Mc Marmac & Mafic Volcanics & $\begin{array}{l}\text { Ore hosted in fine-grained quartz contained in large banded Q- } \\
\mathrm{C} \text { bodies }\end{array}$ & $\begin{array}{l}\text { Aspy, Py, Po, (Sp, Cpy, Sch, } \\
\text { St, Vg) }\end{array}$ & No mention about alteration in literature \\
\hline H.G. Young & Mafic Volcanics & Quartz fissure veins & Py, Po, Aspy (Sch) & No mention about alteration in literature \\
\hline $\begin{array}{l}\text { Madsen and Starratt- } \\
\text { Olsen }\end{array}$ & $\begin{array}{l}\text { Mafic Volcanics, Quartz } \\
\text { feldspar crystal tuffs }\end{array}$ & Silicified lenses and disseminations, Quartz veins, stringers & $\begin{array}{l}\text { Py, Po, Aspy, Sp, Cpy, Mt, ( } \\
\text { Sch, Mb, VG) }\end{array}$ & $\begin{array}{l}\text { Local carbonate, Silicate, } \\
\text { Biotite, Sericite, Aluminous }\end{array}$ \\
\hline Wilmar & Basalt, Granodiorite & $\begin{array}{l}\text { Mineralized fault breccia. Ore within a brecciated carbonate } \\
\text { zone and in narrow quartz-filled fractures cutting granodiorite }\end{array}$ & $\begin{array}{l}\text { Po, Py, Cpy, (Aspy, Sp, Sch, } \\
\text { Tellurides (Hessite, Petzite, } \\
\text { Calaverite), Argentite, Ruby } \\
\text { silver, Gersdorffite,VG, VS) }\end{array}$ & $\begin{array}{l}\text { Carbonate, Silicate, Epidote, Sericite, Chlorite, } \\
\text { Fuchsite }\end{array}$ \\
\hline Gold Eagle Mine & Greywacke, Granodiorite & Quartz veins emplaced in open space fissure fillings & $\begin{array}{l}\text { Py, Sp, (Aspy, Cpy, Sch, Ga, } \\
\text { Tellurides (Sylvanite, Altaite), } \\
\text { Mb, VG) }\end{array}$ & $\begin{array}{l}\text { Carbonate, Sericite, } \\
\text { Albite, Chloritization of biotite, } \\
\text { Biotite pseudomorphs after hornblende }\end{array}$ \\
\hline McKenzie Red Lake & Granodiorite, Diorite & $\begin{array}{l}\text { Quartz }+/ \text {-Albite filled fractures and fissures. Best ore grades } \\
\text { occur where veins flatten or changes strike. At depth fractures } \\
\text { increase in number but decrease in size and are further apart. }\end{array}$ & $\begin{array}{l}\text { Py, Sp, (Po, Aspy, Cpy, Sch, } \\
\text { Ga, Ja, Tellurides (Krennerite, } \\
\text { Petzite, Altaite), VG) }\end{array}$ & $\begin{array}{l}\text { Sericitization, Chloritization, } \\
\text { Carbonatization, Albitization, } \\
\text { Hornblende is altered to biotite carbonate and } \\
\text { chlorite }\end{array}$ \\
\hline Red Lake Gold Shore & Granodiorite & $\begin{array}{l}\text { Downward constricting pipe-like ore shoot consisting of } \\
\text { mineralized quartz lenses and stringers. }\end{array}$ & $\begin{array}{l}\text { Py, Cpy, (Sp, Tet, Tellurides } \\
\text { (Altaite), VG) }\end{array}$ & $\begin{array}{l}\text { Silicate, Chloritization of biotite, Sericite, } \\
\text { Carbonate }\end{array}$ \\
\hline Howey and Hasaga & $\begin{array}{l}\text { Quartz albite porphyry } \\
\text { dyke which intrudes a } \\
\text { volcanic breccia unit }\end{array}$ & $\begin{array}{l}\text { Stockwork to sheeted quartz veins and stringers. Gold values } \\
\text { decrease with depth and to the east. }\end{array}$ & $\begin{array}{l}\text { Py, Sp, (Ga, Cpy, Po, Aspy, } \\
\text { Sch, Polybasite, Tet, Tellurides } \\
\text { (Altaite, Sylvanite), VG) }\end{array}$ & $\begin{array}{l}\text { Sericitization of feldspar and biotite, Silicate, } \\
\text { Chloritization of biotite, Carbonate, Biotite } \\
\text { alteration within the porphyry and in adjacent } \\
\text { country rock }\end{array}$ \\
\hline East Bay Trend & $\begin{array}{l}\text { Basalt, Ultramafic, } \\
\text { Granodiorite }\end{array}$ & $\begin{array}{l}\text { Typically fracture-filling and replacement veins with } \\
\text { occasional hydraulic breccias. Variety of veins composed of } \\
\text { quartz, quartz-carbonate, quartz-actinolite, and late stage } \\
\text { quartz-tourmaline veins. }\end{array}$ & $\begin{array}{l}\text { Py, Po, Aspy (Sp, Cpy, Ga, Mt, } \\
\text { VG) }\end{array}$ & $\begin{array}{l}\text { Strong Carbonate and Silica alteration } \\
\text { surrounding veins. Chlorite, Biotite, Sericite } \\
\text { and occasional fuchsite along wallrocks. } \\
\text { Chloritization of Biotite }\end{array}$ \\
\hline
\end{tabular}


Table 5.4 - Geological characteristics of several world-class gold deposits with the addition of the generalized East Bay Trend deposits from this study.

\begin{tabular}{|c|c|c|c|c|c|c|}
\hline Deposit & Host Rocks & $\begin{array}{l}\text { Metamorphic } \\
\text { Grade }\end{array}$ & Veining Styles & Characteristics & Alteration & Reference \\
\hline East Bay Trend & $\begin{array}{l}\text { Basalt, } \\
\text { Ultramafic, } \\
\text { Granodiorite }\end{array}$ & $\begin{array}{l}\text { Lower to upper } \\
\text { greenschist }\end{array}$ & $\begin{array}{l}\text { Siliceous replacement Q-C veins, } \\
\text { Siliceous replacement of carbonate } \\
\text { veins. Fracture-filling quartz veins. } \\
\text { Quartz-actinolite \& quartz-tourmaline } \\
\text { veins }\end{array}$ & $\begin{array}{c}\text { Primary inclusions are } \mathrm{H}_{2} 0-\mathrm{CO}_{2}, 75- \\
80 \mathrm{~mol} \% \mathrm{CO}_{2}, \sim 9-20 \text { wt } \% \mathrm{NaCl}, \\
\sim 220^{\circ} \mathrm{C} \text { for late qtz-tour veins } \\
\text { (geothermometry) } \sim 200-350^{\circ} \mathrm{C} \\
\text { main ore stage }(\mathrm{Th}) . \text { Fluid is } \\
\text { composed } \mathrm{CO}_{2}, \mathrm{H}_{2} \mathrm{O}, \text { and } \mathrm{CH}_{4} . \\
\delta^{18} \mathrm{O}_{\text {quartz }} \text { of } 9.6-13.1 \% 0\end{array}$ & $\begin{array}{l}\text { Strong Carbonate and Silica alteration } \\
\text { surrounding veins. Chlorite, Biotite, } \\
\text { Sericite and occasional fuchsite along } \\
\text { wallrocks. Chloritization of Biotite }\end{array}$ & This Study \\
\hline $\begin{array}{l}\text { Eastern Abitibi } \\
\text { Belt, Eastern } \\
\text { Canada }\end{array}$ & $\begin{array}{l}\text { Metavolcanics, } \\
\text { metasediments, } \\
\text { porphyries, } \\
\text { granitic rocks }\end{array}$ & $\begin{array}{l}\text { Upper greenschist to } \\
\text { amphibolite }\end{array}$ & $\begin{array}{l}\text { Quartz-carbonate shear zone } \\
\text { hosted, extensional quartz veins, } \\
\text { porphyry epithermal quartz veins, } \\
\text { VMS hosted gold. }\end{array}$ & $\begin{array}{c}\text { Primary inclusions are } \mathrm{H}_{2} \mathrm{O}-\mathrm{CO}_{2}, 5- \\
40 \mathrm{~mol} \% \mathrm{CO}_{2},<2 \mathrm{wt} \% \mathrm{NaCl}, \sim 200- \\
350^{\circ} \mathrm{C}(\mathrm{Th}) . \\
\delta^{18} \mathrm{O}_{\text {quartz }} \text { of } 12.5-15 \% 0\end{array}$ & $\begin{array}{c}\text { Silicification and carbonitization } \\
\text { dominate. Chlorite, biotite, sericite, } \\
\text { sulphides are dominant alteration } \\
\text { minerals. }\end{array}$ & $\begin{array}{l}\text { Smith et al. (1984), } \\
\text { Kerrich (1987), } \\
\text { Beaudoin \& Pitre } \\
\text { (2005), Gosselin \& } \\
\text { Dube, (2005) }\end{array}$ \\
\hline Hemlo & $\begin{array}{l}\text { Felsic to } \\
\text { intermediate } \\
\text { feldspar-phyric } \\
\text { metavolcanics, } \\
\text { metasediments }\end{array}$ & $\begin{array}{l}\text { Upper Greenschist to } \\
\text { mid-amphibolite }\end{array}$ & $\begin{array}{l}\text { Fracture/shear-filling quartz veins, } \\
\text { quartz-carbonate veins }\end{array}$ & $\begin{array}{c}\text { Primary inclusions are } \mathrm{H}_{2} \mathrm{O}-\mathrm{CO}_{2},<20 \\
\mathrm{~mol} \% \mathrm{CO}_{2}, 5.2-37 \mathrm{wt} \% \mathrm{NaCl}, 200- \\
400^{\circ} \mathrm{C} \text { (Th \& geothermometry) } \\
\delta^{18} \mathrm{O}_{\text {quartz }} \text { of } 13.9-17.7 \% 0\end{array}$ & $\begin{array}{l}\text { Microclinization, sericitization, } \\
\text { biotitization, silicification, } \\
\text { carbonatization, albitization, } \\
\text { pyritization, and tourmalinization }\end{array}$ & $\begin{array}{c}\text { Schnieders et al } \\
\text { (1991), Pan \& Fleet } \\
\text { (1992), Kuhns et al. } \\
\text { (1994) }\end{array}$ \\
\hline $\begin{array}{l}\text { Ashanti Gold } \\
\text { Mine, Ghana }\end{array}$ & $\begin{array}{l}\text { Turbidites, } \\
\text { Greywacke, } \\
\text { Metavolcanics }\end{array}$ & Lower greenschist & $\begin{array}{l}\text { Quartz-Carbonate vein hosted. Also } \\
\text { lesser quartz veins and stockworks. }\end{array}$ & $\begin{array}{l}\text { Primary inclusions are } \mathrm{H}_{2} \mathrm{O}-\mathrm{CO}_{2}, 85- \\
90 \mathrm{~mol} \% \mathrm{CO}_{2},<6 \mathrm{wt} \% \mathrm{NaCl}, \sim 350- \\
400^{\circ} \mathrm{C} \text { (geothermometry). Fluid is } \\
\text { composed } \mathrm{CO}_{2}, \mathrm{H}_{2} \mathrm{O}, \mathrm{CH}_{4} \text {, and } \mathrm{H}_{2} \mathrm{~S} \text {. } \\
\delta^{18} \mathrm{O}_{\text {quartz }} \text { of } 14.4-17.4 \% 0\end{array}$ & $\begin{array}{l}\text { Extensive carbonatization and } \\
\text { silicification. Muscovite and } \\
\text { sulphides also present. }\end{array}$ & $\begin{array}{l}\text { Mumin et al. (1996), } \\
\text { Yao et al., (2000) }\end{array}$ \\
\hline $\begin{array}{l}\text { Yilgarn District, } \\
\text { Western } \\
\text { Australia }\end{array}$ & $\begin{array}{l}\text { Mafic Schist, } \\
\text { Quartz } \\
\text { Monzonite, } \\
\text { Granodiorite }\end{array}$ & $\begin{array}{l}\text { Greenschist to } \\
\text { amphibolite }\end{array}$ & $\begin{array}{l}\text { Extensional quartz veins, quartz- } \\
\text { carbonate-pyrrhotite veins and } \\
\text { milky quartz veins hosted in shear } \\
\text { systems. }\end{array}$ & $\begin{array}{l}\text { Primary inclusions are } \mathrm{H}_{2} 0-\mathrm{CO}_{2}, 20- \\
30 \mathrm{~mol} \% \mathrm{CO}_{2},<2 \mathrm{wt} \% \mathrm{NaCl}, \sim 200- \\
360^{\circ} \mathrm{C}(\mathrm{Th}) \text {. Early homogenous fluid } \\
\text { with unmixing. } \\
{ }^{18} \mathrm{O}_{\text {quartz }} \text { of } 10.8-12.4 \% 0\end{array}$ & $\begin{array}{l}\text { Silicification and carbonatization. } \\
\text { Zoned assemblages of garnet- } \\
\text { hornblende-plagioclase-calcite } \\
\text { alteration, }\end{array}$ & $\begin{array}{l}\text { Groves et al. (1998), } \\
\text { Knight et al., (2000) }\end{array}$ \\
\hline
\end{tabular}




\section{ChAPTER 6 - CONCLUSIONS \& FUtURE WORK}

\section{1 - Conclusions}

The East Bay Trend is a structurally and geochemically complex corridor that demonstrates great gold potential. Significant exploration has taken place in the past, yet no world-class deposits have been identified even though there are several similarities with the nearby Red Lake Gold Mines. Based on the findings of this and previous studies the following conclusions can be made:

- Deposit locations are structurally controlled by $\mathrm{S}_{1}$ or the intersection between $S_{1}$ and $S_{2}$. Many of the veins are infill fractures or occur within extensional structuresthat provide a major pathway for fluid movement.

- Gold depositional mechanisms include immiscibility and effervescence, which occur at most deposit areas throughout the East Bay Trend. Mechanisms of minor importance include fluid mixing (restricted to localized areas) and sulphidation seems to have a limited role, while post-depositional modification has affected the Abino area.

- Fluids from veins appear to be primarily carbonaceous with generally low quantities of aqueous inclusions, as well as a significant amount of three phase inclusions. The fluid inclusions from the EBT have a higher aqueous component that at the RLGM (Chi, 2003; 2009).

- Carbonate isotopes $\left(\delta^{13} \mathrm{C} \& \delta^{18} 0\right)$ from Red Lake indicate elevated isotopic values compared to other lode gold systems. These elevated values are 
attributed to the high quantity of methane and organic matter present in the carbonate system.

- Sulphur isotopes on pyrites indicate a magmatic/meteoric origin for fluids, which also correlates with the accepted $\delta^{34} S$ values for sulphides from typical lode gold deposits.

- Oxygen isotopes on mineralized quartz veins indicate that the EB deposits straddle the boundary between mesozonal and epizonal deposit types. The $\delta^{18} 0$ values of barren veins are different than the auriferous veins. The barren veins occur between $\sim 0.0$ and $8 \%$ ond auriferous veins between $\sim 8$ and $13 \%$.

- Oxygen isotopes from equilibrium mineral pairs from quartz-tourmaline veins provide temperatures of $\sim 225^{\circ} \mathrm{C} \pm 50^{\circ} \mathrm{C}$. An original source fluid $\delta^{18} \mathrm{O}$ composition between 6.95 and 7.19\%o.

- The EBT deposits have undergone a complex and protracted history that can only be explained by a multi-stage model for the development of mineralization that likely occurs in the lower mesozonal regime. 


\section{2 - Recommendations for Future Work}

Significant work still remains in the East Bay Trend region, as most of the regional focus remains on the Red Lake Gold Mines and the Mine Trend. Many questions still remain regarding the structural regime, fluid source, timing of events throughout East Bay, etc. Some suggestions for future work include:

1. Correlation of drill core data to develop detailed cross sections throughout the East Bay Trend to relate lithologies and correlate veins and structures.

2. Detailed structural interpretation of the $D_{1}$ and $D_{2}$ structures that occur in East Bay, as well as all other structures, faults, and shears that are present. Use drill core data to better define the structures that occur beneath East bay.

3. In-depth geochemical analysis of the deposits throughout the East Bay Trend to better understand the mineralization style and identify characteristics.

a. Whole rock geochemistry of host rocks, alteration, and veins to characterize each deposit area and compare them. 
b. Identify which elements are closely associated with gold mineralization (if any) to see if element vectoring in the same in East Bay as it is at the Red lake Gold Mines.

4. Complete a detailed stable isotope study of the eastern Red Lake belt, focusing on the mine sites and any significant gold showings.

a. Establish the $\delta^{18} 0$ signature of quartz veins in auriferous zones relative to barren zones to identify variations.

b. Identify further mineral pairs and use stable isotopes to better establish temperatures and ore fluid compositions of different veins (quartz-iron oxides, quartz-sheelite, quartz-tourmaline, and quartz-carbonate are all possible in Red Lake)

c. Use $\delta \mathrm{D}$ on vein associated micas to better constrain source fluids

5. Further age dating of the veining and alteration to properly place the deposits into the time scale.

a. Use further Ar-Ar geochronology on potassic alteration halos that surround mineralized and barren veins.

b. Identify titanite, rutile or zircon that are contemporaneous with the veining events to determine accurate ages.

c. Attempt Re-Os geochronology on the sulphides throughout the Red Lake belt to determine their true ages and if they are pre-, syn-, or post-mineralization. 


\section{References}

Aleinikoff, J.N., Witsch, R.P., Tollo, R.P., Unruh, D.H., Fanning, C.M and Schmitz, M.D., 2007, Ages and origins of the Killingworth Dome, south-central Connecticut: implications for the tectonic evolution of southern New England. American Journal of Science, 307, pp. 63-118.

Bakker, R.J., 1997, CLATHRATES: Computer programs to calculate fluid inclusion V$\mathrm{X}$ properties using clathrate melting temperatures, Computers and Geosciences, 23, pp. 1-18.

Bakker, R.J., 2003, Package FLUIDS 1: Computer programs for analysis of fluid inclusion data and for modeling bulk fluid properties, Chemical Geology, 194, pp. 3-23.

Beaudoin, G., and Pitre, D., 2005, Stable isotope geochemistry of the Archean Vald'Or (Canada) orogenic gold vein field, Mineralium Deposita, 40, pp. 59-75.

Blamart D., 1991, Les concentrations tungstifères et stannifères: caractérisation isotopique (H-O) des fluides minéralisateurs, sur l'exemple du gisement Sn-W de Walmes (Maroc central). Détermination de quelques fractionnements isotopiques $(\mathrm{H}-\mathrm{O})$ entre minéraux et eaux. Thèse de doctorat, Institut National Polytechnique de Lorraine.

Bodnar, R.J., 2003, Interpretation of Data from Aqueous-Electrolyte Fluid Inclusions, Samson, I., Anderson, A., and Marshall, D., Editors, Mineralogical Association of Canada, Short Course Series Volume 32, Chapter 4, pp. 81-100

Bohlke, J.K., Coveney, R.M., Rye, R.O., and Barnes, I., 1988, Stable isotope investigation of gold quartz veins at the Oriental Mine, Alleghany District, California, United States Geological Survey, Open File report 88-279, 27 p.

Bowers, T.S., 1991, The deposition of gold and other metals: pressure induced fluid immiscibility and associated stable isotope signatures, Geochimica Cosmochimica Acta, 55, pp. 2427-2434

Brooking, S., Chantigny., and Chastko, L., 2009, 2007 Annual Diamond Drilling Assessment Report - Cochenour-Willans Property, Dome Township, Red Lake, Ontario, Goldcorp Inc. Internal Report, 1199 p.

Burruss, R.C., 2003, Raman Spectroscopy of Fluid inclusions, Samson, I., Anderson, A., and Marshall, D., Editors, Mineralogical Association of Canada, Short Course Series Volume 32, Chapter 11, pp. 279-289

Cadieux A.-M., Dubé, B., Williamson, K., Malo, M., and Twomey, T., 2006, 
Characterization of hydrothermal alterations at the Red lake mine, Northwestern Ontario. Geological Survey of Canada, Current Research C2, 16 p.

Cameron, E.M., and Hattori, K., 1985, The Hemlo gold deposits, Ontario: a geochemical and isotope study, Geochimica et Cosmochimica Acta, 49, pp. 2041-2050.

Cathles, L.M., 1993, Oxygen Isotope Alteration in the Noranda Mining District, Abitibi Greenstone Belt, Quebec, Economic Geology, 88, pp. 1483-1511.

Chi, G., Lai, J., Solomon, A., 2010, Fluid Inclusion and Stable Isotope Study of the Buffalo Gold Deposit, Red Lake Greenstone Belt, Northwestern Ontario, Canada, Exploration and Mining Geology, 19, pp. 135-149

Chi, G., Yongxing, L., and Dubé, B., 2009, Relationship between CO2-dominated fluids, hydrothermal alterations and gold mineralization in the Red Lake greenstone belt, Canada. Applied Geochemistry, 24, pp. 504-516.

Chi, G., Dubé, B., Williamson, K., and Williams-Jones, A.E., 2006, Formation of the Campbell-Red Lake gold deposit by H2O-poor, CO2-dominated fluids. Mineralium Deposita, 40, pp. 726-741.

Chi, G., Dubé, B., and Williamson, K., 2003, Fluid evolution and pressure regimes in the Campbell-Red Lake gold deposit, Red Lake mine trend, Red Lake, Ontario: Fluid-inclusion evidence for a protracted, highly dynamic hydrothermal system: Geological Survey of Canada Current Research 2003 - C28, 16 p.

Chi, G., Dubé, B., and Williamson, K., 2002, Preliminary fluid-inclusion microthermometry study of fluid evolution and temperature-pressure conditions in the Goldcorp High-Grade zone, Red Lake mine, Ontario: Geological Survey of Canada Current Research 2002 - C27, 14 p.

Clayton R. N. and Kieffer S. W.,1991. Oxygen isotope thermometer calibrations. In StableIsotope Geochemistry. A Tribute to Samuel Epstein (ed. H. P. Taylor et al.) Geochem. Soc. Spec. Pub. 3, pp. 3-10

Corfu, F., and Andrews, A.J., 1987, Geochronological constraints on the timing of magmatism, deformation and gold mineralization in the Red Lake greenstone belt, Northwestern Ontario, Canadian Journal of Earth Science, 24, pp. 13021320.

Corfu, F., and Wallace, H., 1986, U-Pb zircon age for magmatism in the Red Lake greenstone belt, Northwestern Ontario, Canadian Journal of Earth Science, 23, pp. 27-42 
Coulibaly, Y., Boiron, M.C., Cathelineau, M., Kouamelan, A.N., 2007, Fluid immiscibility and gold deposition in the Birimian quartz veins of the Angovia deposit (Yaoure, Ivory Coast), Journal of African Earth Sciences, 50, pp. 234254.

Couture, J-F., 2003, Geological/Structural Study of the East Bay Project, Red Lake, Ontario, Goldcorp internal report prepared by: Steffen, Robertson and Kirsten (Canada) Inc., 69 p.

Crick, D., Blais, S., and Stechishen, A., 2006, The Red Lake Gold Mines Property, Red Lake Mining Division, Northern Ontario, NI43-101 report by Goldcorp Inc. personnel, 142 p. excluding figures and appendices; posted on Sedar.

Craw, D., Teagle, D.A.H., Belocky, R., 1993, Fluid immiscibility in late Alpine goldbearing veins, eastern and northern European Alps, Mineralium Deposita, 28, pp. 28-36.

Diakow, L.J., Panteleyev, A., and Schroeter, T.G., 1991, Jurassic epithermal deposits in the Toodoggone River area, northern British Columbia: Examples of wellpreserved, volcanic-hosted, precious metal mineralization, Economic Geology, 86, pp. $529-554$.

Diamond, L.W, 1994, Introduction to phase relations of CO2-H2O fluid inclusions. In: De Vivo, B. and Frezzotti, M.L. (eds.), Fluid Inclusions in Minerals: Method and Application. Virginia Polytechnic Institute \& State University, Blacksburg, pp. 131-158.

Diamond, L.W., 1990, Fluid inclusion evidence for P-V-T-X evolution of hydrothermal solutions in late-Alpine gold-quartz veins at Brusson, Val D’Ayas, northwest Italian Alps, American Journal of Science, 290, pp. 912-958.

Dilworth, K, 2000, Petrographic and Mineral Chemistry Studies of the Kathi Unit: Campbell Mine, Balmertown, Northwestern Ontario, Unpublished B.Sc. thesis, Kingston Canada, Queens University, 85 p.

De Ronde, C.E.J., and Blattner, P., 1988, hydrothermal alteration, stable isotopes, and fluid inclusions of the Golden Cross Epithermal Gold-Silver Deposit, Waihi, New Zealand, Economic Geology, 83, pp. 895 - 917.

Dubé, B., and Gosselin, P., 2007, Greenstone-hosted quartz-carbonate vein deposits, in Goodfellow, W.D., ed., Mineral Deposits of Canada: A Synthesis of Major Deposit-Types, District Metallogeny, the Evolution of Geological Provinces, and Exploration Methods: Geological Association of Canada, Mineral Deposits Division, Special Publication No. 5, pp. 49-73.

Dubé, B., Williamson, K., McNicoll, V., Malo, M., Skulski, T., Twomey, T., and 
Sanborn-Barrie, M., 2004, Timing of Gold Mineralization at Red Lake, Northwestern Ontario, Canada: New Constraints from U-Pb Geochronology at the Goldcorp High-Grade Zone, Red Lake Mine, and the Madsen Mine. Economic Geology, 99, pp. 1611-1641.

Dubé, B., Williamson, K., and Malo, M., 2002, Geology of the Goldcorp Inc. High-Grade zone, Red Lake mine, Ontario: An update: Geological Survey of Canada Current Research 2002-C26, 15 p.

Dubé, B., Williamson, K., and Malo, M., 2001, Preliminary report on the geology and controlling parameters of the Goldcorp Inc. High-Grade zone, Red Lake mine, Ontario, Geological Survey of Canada Current Research 2001-C18, 33 p.

Dumoulin, M., 2009. Diamond Drilling Assessment Report - East Bay/Duchesne Property, Bateman Township, Red Lake, Ontario, Goldcorp Inc. Internal Report, $330 \mathrm{p}$.

El Bilali, H. and Hattori, K., 1998, High ${ }^{13} \mathrm{C}$ and ${ }^{34} \mathrm{~S}$ in carbonates and sulfide minerals associated with gold at the Red Lake Greenstone belt: Evidence from deformation zones and Campbell Mine. Abstracts Geol. Soc. Amer., 30, no. 7, pp. $369-370$

English, P. J., 1981, Gold-quartz veins in metasediments of the Yellowknife Supergroup Northwest Territories: A fluid inclusion study: Unpublished M.Sc. thesis Edmonton, Canada, University of Alberta, 108 p.

Faure, G., and Mensing, T., 2005. Isotopes: Principles and Applications, third edition, John Wiley \& Sons, Inc., Hoboken, New Jersey, 896 p.

Faure, K., Matsuhisa, Y., Metsugi, H., Mizota, C., and Hayashi, S., 2002, The Hishikari $\mathrm{Au}-\mathrm{Ag}$ Epithermal Deposit, Japan: Oxygen and hydrogen isotope evidence in determining the source of paleohydrothermal fluids. Economic Geology, 97, pp. $481-498$.

Fayek, M., Harrison, T.M., Ewing, R.C., Grove, M., and Coath, C.D., 2002, 0 and Pb isotopic analyses of uranium minerals by ion microprobe and $\mathrm{U}-\mathrm{Pb}$ ages from the Cigar Lake deposit, Chemical Geology, 85, pp. 205 - 225.

Ferguson, S.A., 1966, Geology of Dome Township, District of Kenora, Ontario Department of Mines, Geological Report 45, $121 \mathrm{p}$.

Fumerton, S., Shannon, K., and St. Louis, C., 1990, Final Report on the Goldquest Project, In the East Bay Area, Red Lake, Ontario, Chevron Minerals Ltd. internal report, $74 \mathrm{p}$.

Gleeson, S.A., 2003. Bulk Analysis of Electrolytes in Fluid Inclusions; in Fluid 
Inclusions: Analysis and Interpretation, Samson, I., Anderson, A., and Marshall, D., Editors, Mineralogical Association of Canada, Short Course Series Volume 32, Chapter 9, pp. 233-246

Goldcorp Inc., 2006, East Bay Project; Pre-Feasibility Study Report, Bateman Township, Red Lake District, 233 p.

Goldfarb, R.J., Newberry, R,J., Pickthorn, W.J., and Gent, C.A., 1991, Oxygen, hydrogen, and sulfur isotope studies in the Juneau Gold Belt, southeastern Alaska: Constraints on the origin of hydrothermal fluids, Economic Geology, 86, pp. 66-80.

Gosselin, P., and Dubé, B., 2005, Gold deposits of Canada: distribution, geological parameters and gold content: Geological Survey of Canada, Open File 4896, $105 \mathrm{p}$.

Groves, D.I., Goldfarb, R.J., Gebre-Mariam, M., Hagemann, S.G., Robert, F., 1998, Orogenic gold deposits: A proposed classification in the context of their crustal distribution and relationship to other gold deposit types, Ore Geology Reviews, 13, pp. 7-27

Hagemann, S.G., and Cassidy K.F., 2000, Archean orogenic gold deposits: Reviews in Economic Geology, 13, pp. 9-68

Harraz, H.Z., 2002, Fluid inclusions in the mesozonal gold deposit at Atud mine, Eastern Desert, Egypt, Journal of African Earth Sciences, 35, pp. 347-363

Hodkiewicz, P.F., Groves, D.I., Davidson, G.J., Weinberg, R.F., Hagemann, S.G., 2008, Influence of structural setting on sulphur isotopes in Archean orogenic gold deposits, Eastern Goldfields Province, Yilgarn, Western Australia, Mineralium Deposita, 44, pp. 129-150.

Hodkiewicz, P.F., 2003, The Interplay Between Physical and Chemical Processes in the Formation of World-Class Orogenic Gold Deposits in the Eastern Goldfields Province, Western Australia, Unpublished Ph.D. thesis Perth, Australia, University of Western Australia, 236 p.

Hogg, G.M., 2002, Technical report on the McFinley Mine property of Rubicon Minerals Corportaion, NI43-101, G.M. Hogg and Associates Ltd., 27p.

Holt, M.E., 1988, Valuation of Wilanour Resources Limited, Wilmar Mines Limited and Annco Mines Limited, Red lake Area, Northwestern Ontario, Internal company report, $44 \mathrm{p}$.

Horwood, H.C., 1940, Geology and Mineral Deposits of the Red Lake Area; Ontario Department of Mines 49th Annual Report, Vol. XLIX, Part II, 219 p. 
Ireland, T.R., Clement, S., Compston, W., Foster, J.J., Holden, P., Jenkins, B., Lanc, P., Schram, N., \& Williams, I.S., 2008, Development of SHRIMP, Australian Journal of Earth Sciences: An International Geoscience Journal of the Geological Society of Australia, 55, pp.937-954

Kawabe, I., 1978, Calculation of oxygen isotopic fractionation in quartz-water system with special reference to the low temperature fractionation, Geochim. Cosmochim. Acta, 42, pp. 613-621.

Kelly J. L., Fu B., Kita N. T. and Valley J. W., 2007, Optically continuous silcrete quartz cements of the St. Peter Sandstone: high precision oxygen isotope analysis by ion microprobe, Geochimica et Cosmochimica Acta, 71, p. 3812-3832.

Kerrich, R., 1987, The stable isotope geochemistry of Au-Ag vein deposits in metamorphic rocks, Chp. 7, Kyser, T.K., (Eds), Short Course in Stable Isotope Geochemistry of Low Temperature Fluids, Mineralogical Association of Canada, Short Course Series, Vol. 13, pp. 287-336.

Kerrich, R., Fryer, B.J., King, R.W., Willmore, L.M., Van Hees, E., and Doddar, R., 1987, Crustal outgassing and LILE enrichment in major lithosphere structures, Archean Abitibi greenstone belt: evidence on the source reservoir from $\mathrm{Sr}$ and C isotope tracers, Contrib. Mineral. Petrol., 97, no. 2, pp. 156-168.

Kesler, S.E., Riciputi, L.C., Ye, Z., 2005, Evidence for a magmatic origin for Carlin-type gold deposits: isotopic composition of sulfer in the Betze-Post-Screamer Deposit, Nevada, USA, Mineralium Deposita, 40, pp. 127-136

Kesler, S.E., 2004, Gold in Sulphide Minerals and Ore Deposits , The Gangue - G.A.C Mineral Deposits Division, 83, pp. 1-8.

Klein, E.l., Fuzikawa, K., Koppe, J.C., 2000, Fluid inclusion studies on Caxias and Areal gold mineralizations, Sao Luis Craton, northern Brazil, Journal of Geochemical Exploration, 71, pp. 51-72

Knight, J.T., Ridley, J.R., and Groves, D.I., 2000, The Archean Amphibolite Facies Coolgardie Goldfield, Yilgarn Craton, Western Australia: Nature, Controls, and Gold Field-Scale Patterns of Hydrothermal Wall-Rock Alteration, Economic Geology, 95, pp. 49-84

Kontak, D.J., Horne, R.J., and Kyser, K., 2011, An oxygen isotope study of two contrasting orogenic vein gold systems in the Meguma Terrane, Nova Scotia, Canada, with implications for fluid sources and genetic models, Mineralium Deposita, 46, p. 289 - 304.

Kontak, D.J., Smith, P.K., Kerrich, R., and Williams, P.F., 1990, Integrated model for 
Meguma Group lode gold deposits, Nova Scotia, Canada, Geology, 18, pp. 238242

Kuhns, R.J., Sawkins, F.J., and Ito, E., 1994, Magmatism, Metamorphism and Deformation at Hemlo, Ontario, and the Timing of Au-Mo Mineralizationi $n$ the Golden Giant Mine, Economic Geology, 89, pp. 720-756

Kusakabe, M., 1974, Sulphur isotope variations in nature: 10. Oxygen and sulphur isotope study or Wairakei geothermal well discharges, New Zealand, J. Sci., 17, pp. 183-191.

Kyser, T.K., 1987, Equilibrium fractionation factors for stable isotopes, Chp. 1, Kyser, T.K., (Eds), Short Course in Stable Isotope Geochemistry of Low Temperature Fluids, Mineralogical Association of Canada, Short Course Series, Vol. 13, pp. 1-84.

Lavigne, M.J., and Crocket, J.H., 1982, A comparative study of sulphur isotope distribution of sulphide facies banded iron formations and the east south $\mathrm{C}$ ore zone, Dickenson Gold Mine, Red Lake District: A preliminary report. Current Research Part A, Geological Survey of Canada, Paper 82-1A, pp. 265274

Lee, I., and Shin, D., 2003, Trimodal distribution of C02-bearing fluid inclusions in the gold-silver bearing quartz veins of the Phuoc Thanh area, Central Vietnam: Its implication to the Au-Ag precipitation, Geosciences Journal, 7, pp. 21-26

Lichtblau, A.F., Ravnaas, C., Storey, C.C., Bongfeldt, J., Lockwood, H.C., and Wilson, A.C., 2012, Red Lake Regional Resident Geologist Report: Red Lake and Kenora Districts Ontario Geological Survey, Open File Report 6271, 122 p.

Ludwig, K.R., 2001, SQUID 1.03, A User's Manual; Berkeley Geochronology Center Special Publication No. 2, 19 pp.

Ludwig, K.R., 2003, Isoplot 3.00: A Geochronological Toolkit for Microsoft Excel. Berkeley Geochronology Center Special Publication No. 4, 70 pp.

MacGeehan, P.J., and Hodgson, C.J., 1982, Environments of Gold Mineralization in the Campbell Red Lake and Dickenson Mines, Red Lake District, Ontario, Canadian Institute of Mining and Metallurgy Special Volume: Geology of Canadian Gold Deposits, pp. 184-207

Marsden, S., 2012, Geology, Hydrothermal Alteration and Mineralization of the Gold Eagle Deposit: A New Discovery in the Red Lake Camp, Canada: Unpublished M.Sc. thesis, Kingston, Ontario, Queens University, 147 p. 
Mason-Apps, G., 2002, Abino Project: Executive Summary, Goldcorp Inc., Red Lake, Ontario, Internal document, $46 \mathrm{p}$.

McCuaig, T.C., and Kerrich, R., 1998, P-T-t deformation-fluid characteristics of lode gold deposits: evidence from alteration systematics, Ore Geology Reviews, 12, pp. 381-453.

McDonald, BWD, 1990, Geology and Genesis of the Mount Skukum Epithermal GoldSilver Deposits, Southwestern Yukon Territory (NTS 105D 3, 6), Abbott, J.G. (Eds.), Indian and Northern Affairs Canada, Exploration and Geological Services Division, Yukon Region, Bulletin 2, 73 p.

McMaster, N.D. 1987. A preliminary 40Ar/39Ar study of the thermal history and age of gold in the Red Lake greenstone belt. Unpublished M.Sc. thesis, University of Toronto, Toronto, Ontario.

Menard, T, Pettigrew, N., and Spray, J., 1999, A joint Industry-Lithoprobe project on the tectonic history of gold deposits in the Red Lake greenstone belt, Red Lake Ontario, 2740-2700Ma, Western Superior Transect Fifth Annual Workshop, Lithoprobe Report \#70, pp. 97-103.

Mikucki, E.J., 1998, Hydrothermal transport and depositional processes in Archean lode-gold systems: A review, Ore Geology Reviews, 13, pp. 307-321

Mumin, A.H., Fleet, M.E., Longstaffe, F.J., 1996, Evolution of hydrothermal fluids in the Ashanti gold belt, Ghana: stable isotope geochemistry of carbonates, graphite and quartz, Economic Geology, 91, pp. 135-148.

Neumayr, P., Hagemann, S.G., Banks, D.A., Yardley, B.W.D., Couture, J-F., Landis, G.P., and Rye, R. (2007): Fluid chemistry and evolution of hydrothermal fluids in an Archean transcrustal fault zone network: the case of the Cadillac Tectonic Zone, Abitibi greenstone belt, Canada. Canadian Journal of Earth Sciences, volume 44, pp. $745-773$.

Noble, S.R., 1989, Geology, geochemistry and isotope geology of the Trout Lake batholith and the Uchi-Confederation Lakes greenstone belt, Northwestern Ontario, Canada, Unpublished Ph.D.. thesis, University of Toronto, Toronto, Ontario, $289 \mathrm{p}$.

O'Dea, M., 1999, Goldcorp Inc. unpublished internal report, posted on www.goldcorp.com in \challenge \references $\backslash$ structure.

Ohmoto, H., 1986, Stable isotope geochemistry of ore deposits, Chp. 14, In Valley, J.W., Taylor, H.P., Jr., and O'Neil, J.R. (Eds), Stable isotopes in High Temperature Geological Processes, Mineral. Assoc, America Reviews in Mineralogy, Vol. 16, pp. 491-559. 
Ohmoto, H., and Rye, R.O., 1979, Isotopes of sulphur and carbon. In: Geochemistry of Hydrothermal Ore Deposits, second edition, Barnes, H.L. (editor). John Wiley and Sons, New Yark, pp. 509-567

O'Neil, J.R., 1986, Theoretical and experimental aspects of isotopic fractionation, Chp. 1, In Valley, J.W., Taylor, H.P., Jr., and O’Neil, J.R. (Eds), Stable isotopes in High Temperature Geological Processes, Mineral. Assoc, America Reviews in Mineralogy, Vol. 16, pp. 185-225.

Pan, Y., and Fleet, M.E., 1992, Calc-Silicate Alteration in the Hemlo Gold Deposit, Ontario: Mineral Assemblage P-T-X Constraints and Significance, Economic Geology, 87, pp. 1104-1120

Parker, J.R., 2000, Gold mineralization and wallrock alteration in the Red Lake greenstone belt: A regional perspective; in Summary of Field Work and Other Activities, Ontario Geological Survey, Open File Report 6032, pp. 22-1 - 2228.

Penczak, R., 1999, Geochemistry and alteration around some high-grade zones and geochemical characteristics of altered rocks at the Red Lake Mine, Unpublished Company Report, Goldcorp Canada Inc., Red Lake Mine Division, $86 \mathrm{p}$.

Penzak, R., and Mason, R., 1999, Characteristics and Origin of Archean Premetamorphic Hydrothermal Alteration at the Campbell Gold Mine, Northwestern Ontario, Canada, Economic Geology, 94, pp. 507-528.

Penzak, R., and Mason, R., 1997, Metamorphosed Archean epithermal Au-As-Sb-Zn(Hg) vein mineralization at the Campbell Mine, northwestern Ontario; Economic Geology, 92, pp. 696-719.

Penczak, R., 1996, The geological context of alteration and gold mineralization at the Campbell mine, Red Lake district, Ontario, Unpublished M.Sc. thesis, Kingston, Ontario, Queen's University, 334 p.

Pirie, J., 1981, Regional geological setting of gold deposits in the Red Lake area, northwestern Ontario: Ontario Geological Survey Miscellaneous Paper 97, pp. 71-93

Poulsen, K.H., Robert, F., and Dubé, B., 2000, Geological Classification of Canadian Gold Deposits, Geological Survey of Canada Bulletin 540,113p.

Ramboz, C., Pichavant, M., Weisbrod, A., 1982, Fluid immiscibility in natural processes: use and misuse of fluid inclusion data, Chemical Geology, 37, pp. 29-48. 
Revez, K.M., Landwehr, J.M., and Keybl, J., 2001, Measurement of delta ${ }^{13} \mathrm{C}$ and delta ${ }^{18} \mathrm{O}$ Isotopic Ratios of $\mathrm{CaCO}_{3}$ using a Thermoquest Finnigan GasBench II Delta Plus XL Continuous Flow Isotope Ratio Mass Spectrometer with Application to Devils Hole Core DH-11 Calcite. USGS Open-File Report 01-257.

Riciputi, L.R., Paterson, B.A., and Ripperdan, R.L., 1998, Measurement of light stable isotope ratios by SIMS: Matrix effects for oxygen, carbon, and sulfur isotopes in minerals, International Journal of Mass Spectrometry, 178, pp. 81-112.

Rickard, D., Luthor, G.W., 2007, Chemistry of Iron Sulfides, Chem. Rev., 107, pp. 514562

Robb.L.J., 2005. Introduction to ore-forming processes, first edition, Blackwell Publishing, Malden, Massachusetts, 373 p.

Robert, F., Brommecker, R., Bourne, B.T., Dobak, P.J., McEwan, C.J., Rowe, R.R., and Zhou, X., 2007, Models and Exploration Methods for Major Gold Deposit Types, Ore Deposits and Exploration Technology, Paper 48, In "Proceedings of Exploration 07: Fifth Decennial International Conference on Mineral Exploration" edited by B. Milkereit, 2007, p. 691-711

Robert, F., Poulsen, K.H., Cassidy, K.F., Hodgson, C.J., 2005, Gold Metallogeny of the Superior and Yilgarn Cratons, Economic Geology 100th Anniversary Volume, p. 1001-1033.

Robert, F., and Poulsen, H.K., 1997, 'World-class Archaean gold deposits in Canada: An overview', Australian Journal of Earth Sciences, 44, pp. 329 - 351.

Robert, F., 1990, Structural setting and control of gold-quartz veins of the Val d'Or area, southeastern Abitibi subprovince, in Ho, S.E., Robert, F., and Groves, D.I., eds., Gold and Base-Metal Mineralization in the Abitibi Subprovince, Canada, with Emphasis on the Quebec Segment: University of Western Australia, Short Course Notes, v. 24, pp. 167-210.

Robert, F., and Kelly, W.C., 1987, Ore-Forming Fluids in Archean Gold-Bearing Quartz Veins at the Sigma Mine, Abitibi Greenstone Belt, Quebec, Canada, Economic Geology, 82, p. 1464 - 1482.

Roberts, R.G., 1987, Ore Deposit Models \#11, Archean Gold Deposits, Geoscience Canada, 14, no. 1, pp. 37-52.

Roedder, E., 1984. Fluid Inclusions, Mineralogical Society of America, Reviews in Mineralogy, Volume 12, 644 p. 
Rushton, R.W., Nesbitt, B.E., Muehlenbachs, K., and Mortensen, J.K. (1993): A fluid inclusion and stable isotope study of Au quartz veins in the Klondike District, Yukon Territory, Canada: A Section through a Mesothermal Vein System. Economic Geology, 88, p. 647 - 678.

Russell, I., 2011, Personal Communication, Rubicon Minerals Corp.

Rye, R.O., Plumlee, G.S., Bethke, P.M., and Barton, P.B., 1988, Stable Isotope Geochemistry of the Creede, Colorado, Hydrothermal System, United States Geological Survey, Open File Report 88-356, 40 p.

Sanborn-Barrie, M., Skulski, T., and Parker, J.R., 2004, Geology, Red Lake greenstone belt western Superior province, Ontario: Gelogical Survey of Canada Open File 4594, 1:50,000 scale color map.

Sanborn-Barrie, M., Skulski, T., and Parker, J., 2001, 300 m.y. of tectonic history recorded by the Red Lake greenstone belt: Ontario Geological Survey of Canada, Current Research 2001-C19, 32 p.

Sanborn-Barrie, M., Skulski, T., Parker, J., and Dubé, B., 2000, Integrated Regional Analysis of the Red Lake Greenstone Belt and its Mineral Deposits, Western Superior Province, Ontario: Geological Survey of Canada - Current Research 2000-C18, 18 p.

Sanborn, M.M., 1987, The Role of Brittle-Ductile Shear in the Formation of goldbearing quartz-carbonate veins in the West Carbonate Zone of the Cochenour-Willans Gold Mine, Red Lake, Ontario, unpublished M.Sc. thesis, University of Toronto, $189 \mathrm{p}$.

Sannes, D.L., Dehn, M., 2000, Mineral Showings - East Bay Area, Draft Version, Goldcorp Internal Report, $52 \mathrm{p}$.

Saunders, J.A., Unger, D.L., Kamenov, G.D., Fayek, M., Hames, W.E., and Utterback, W.C., 2008, Genesis ofMiddle Miocene Yellowstone-hotspot-related bonanza epithermal Au-Ag deposits, Northern Great Basin Region, USA, Mineralium Deposita, 43, p. 715-734.

Seal, R.R., 2006, Sulfur isotope geochemistry of sulfide minerals, USGS Staff Published Research. Paper 345, 47 p.

Schnieders, B.R., Smyk, M.C., and Muir, T.L., 1991, Hemlo Deposit Overview, Ch. 5, Muir, T.L., Schnieders, B.R., and Smyk, M.C., (Eds), In, Geology and Gold Deposits of the Hemlo Area, Geological Association of Canada Joint Annual Meeting 1991, $126 \mathrm{p}$.

Sharp, Z., 2007, Principles of stable isotope geochemistry, first edition, Pearson 
Education, Inc., Upper Saddle River, New Jersey, 344 p.

Shepherd, T.J., Rankin, A.H., and Alderton, D.H.M., 1985. A Practical Guide to Fluid Inclusion Studies, Blackie \& Son Limited, Bishopbriggs, Glasgow, G64 2NZ, $239 \mathrm{p}$.

Sheppard, S.M.F., 1986, Characterization and isotopic variations in natural waters, Chp. 6. In Valley, J.W., Taylor, H.P., Jr., and O'Neil, J.R., (eds), Stable isotopes in High Temperature Geological Processes, Mineralogical Association of America Reviews in Mineralogy, 16, pp. 165-184.

Sheppard, S.M.F., 1984, Stable isotope studies of formation waters and associated $\mathrm{Pb}-\mathrm{Zn}$ hydrothermal deposits. In: Thermal Phenomena in Sedimentary Basins, Durand, B. (editor), Additions Technic. Paris, pp. 301-317.

Siddorn, J.P., 2011, The Giant-Con gold deposit: A once-linked Archean lode-gold system, unpublished Ph.D. Thesis, University of Toronto, $330 \mathrm{p}$.

Simpson, M.P, and Mauk, J.L., 2011, Hydrothermal alteration and veins at the epithermal Au-Ag deposits and prospects of the Waitekauri Area, Hauraki Goldfield, New Zealand, Economic Geology, 106, pp. 945 - 973.

Smith, H.A., Shannon, J.M., Nussipakynova, D., Pitman, C., Caron, S., and Roy, P., 2011, F2 Gold System - Phoenix Gold Project, Bateman Township, Red Lake Canada, Technical Report NI43-101 for Rubicon Minerals Corp. prepared by AMC Mining Consultants (Canada) Ltd., 188 p.

Smith, T.J., Cloke, P.L., and Kesler, S.E., 1984, Geochemistry of Fluid Inclusions from the McIntyre-Hollinger Gold Deposit, Timmins, Ontario, Canada, Economic Geology, 79, pp. 1265 - 1285.

Stacey, J.S. and Kramers J.D., 1975, Approximation of terrestrial lead isotope evolution by a two-stage model. Earth Planetary Science Lett., 26, pp. 207221.

Steiger, R.H. and Jäger, E., 1977, Subcommission on geochronology: convention on the use of decay constants in geo- and cosmochronology. Earth Planetary Science Lett., 36, pp. 359-362.

Stott, G.M., Corkery, M.T., Percival, J.A., Simard, M. and Goutier, J. 2010. A revised terrane subdivision of the Superior Province; in Summary of Field Work and Other Activities 2010, Ontario Geological Survey, Open File Report 6260, pp. 20-1 to 20-10.

Stott, G.M., and Corfu, F., 1991, Uchi Subprovince; in Geology of Ontario, Ontario Geological Survey, Special Volume 4, pt. 1, pp. 145-236. 
Tarnocai, C., 2000, Gold mineralization at the Campbell mine, Red Lake greenstone belt, Uchi subprovince Ontario: Unpublished Ph.D. thesis, Ottawa, Ontario, University of Ottawa, $227 \mathrm{p}$.

Taylor, B.E., 2007. Epithermal gold deposits, in Goodfellow, W.D., ed., Mineral Deposits of Canada: A Synthesis of Major Deposit-Types, District Metallogeny, the Evolution of Geological Provinces, and Exploration Methods: Geological Association of Canada, Mineral Deposits Division, Special Publication No. 5, pp. 113-139.

Taylor, H.P., $1973,{ }^{18} \mathrm{O} /{ }^{16} \mathrm{O}$ evidence for meteoric-hydrothermal alteration and ore deposition in the Tonopah, Comstock Lode, and Goldfield mining districts, Nevada, Economic Geology, 68, pp. 747-764

Thébaud, N., Phililppot, P., Rey, P., and Cauzid, J., 2006, Composition and origin of fluids associated with lode gold deposits in a Mesoarchean greenstone belt Warrawoona Syncline, Pilbara Craton, Western Australia) using synchrotron radiation X-ray fluorescence. Contributions to Mineralogy and Petrology, 152, pp. $485-503$.

Thomas, R., 2009, Exploration Activities of Rubicon Minerals Corporation on the Phoenix Gold Project, Red Lake, Ontario for the period January 2006 to October 2008, NI43-101 report for Rubicon Minerals Inc., 82 p.; posted on Sedar.

Thompson, P.H., 2003, Toward a new metamorphic framework for gold exploration in the Red Lake greenstone belt; Ontario Geological Survey, Open File Report $6122,52 \mathrm{p}$.

Van den Kerkhof, F., Hein, U., 2001, Fluid inclusion petrography, Lithos, 55, pp. 2747

Van Hees, E.H.P., Shelton, K.L., McMenamy, T.A., Ross, Jr, L.M., Cousens, B.L., Flack, H., Robb, M.E., and Canam, T.W., 1999, Metasedimentary influence on metavolcanic-rock-hosted greenstone gold deposits: Geochemistry of the Giant mine, Yellowknife, Northwest Territories, Canada, Geology, 27, pp. 7174

Wanless, R.K., Boyle, R.W., and Lowdon, J.A., 1960, Sulphur isotope investigations of the gold-quartz deposits of the Yellowknife district, Economic Geology, 55, pp. 1591-1621

Weir, R.H., and Kerrick, D.M., 1987, Mineralogic, fluid inclusion, and stable isotope studies of several gold mines in the Mother Lode, Tuolumne and Mariposa counties, California, Economic Geology, 82, pp. 328-344 
Wilkinson, J.J., 2001, Fluid inclusions in hydrothermal ore deposits, Lithos, 55, pp. 229-272

Williams, I.S., 1998, U-Th-Pb geochronology by ion microprobe. In: Reviews of microanalytical techniques to understanding mineralising processes, McKibben, M.A., Shanks, III, W.C. and Ridley, W.I. (eds), Reviews in Economic Geology, 7, pp. 1- 35.

Winter, J.D., 2001, An Introduction to igneous and metamorphic petrology, first edition, Prentice-Hall, Inc., Upper Saddle River, New Jersey, 697 p.

Yao, Y., and Robb, L.J., 2000, Gold mineralization in Palaeoproterozoic granitoids at Obuasi, Ashanti region, Ghana; ore geology, geochemistry and fluid characteristics, South African Journal of Geology, 103, pp. 255-278

Zairi, N.M., Sher, S.D., Strizhev, V.P., Batrak, V.N., and Pankratyeva, L.D., 1978, Isotopic composition of sulphur from the zone of a gold-bearing sulphide impregnation, International Geology Revue, 20, pp. 935-941.

Zhang, G., Germaine, J.T., Martin, T., and Whittle, A.J., 2003, A simple samplemounting method for random powder x-ray diffraction; Clays and Clay Minerals, 51, no. 2, pp. 218-225

Zhang, X., Nesbitt, B.E., and Muehlenbachs, K., 1989, Gold mineralization in the Okanagan Valley, southern British Columbia: Fluid inclusion and stable isotope studies, Economic Geology, 84, pp. $410-424$.

Zheng, Y.F., 1993, Calculation of oxygen isotope fractionation in anhydrous silicate minerals. Geochim. Cosmochim. Acta, 57, pp. 1079-1091

Zoheir, B.A., 2008, Structural controls, temperature-pressure conditions and fluid evolution of orogenic gold mineralization at the Betam mine, south Eastern Desert, Egypt, Mineralum Deposita, 43, pp. 79-95 
Appendix A

Sample Analysis Listing 
Table A1 - Sample location, mineralogy, and analyses performed on each sample. Samples are listed in order of drill hole and their location within the stratigraphy of the hole. TRM (transmitted \& reflected light microscopy), SEM (scanning electron microscope), EMP (electron microprobe) and WRG (whole rock geochemistry)

\begin{tabular}{|c|c|c|c|c|c|}
\hline Sample & $\begin{array}{l}\text { Sample } \\
\text { Property }\end{array}$ & Location & $\begin{array}{c}\text { Gold } \\
\text { (g/tonne) }\end{array}$ & Dominant Mineralogy & $\begin{array}{l}\text { Analytical } \\
\text { methods }\end{array}$ \\
\hline CO20L-01 & $\begin{array}{l}\text { Cochenour } \\
\text { Mine }\end{array}$ & Drill Core & 0.188 & $\begin{array}{c}\text { Carbonate, Quartz, Amphibole, } \\
\text { Plagioclase }\end{array}$ & TRM \\
\hline CO20L-03 & $\begin{array}{l}\text { Cochenour } \\
\text { Mine }\end{array}$ & Drill Core & 8.113 & Quartz, Actinolite, carbonate & TRM, FI, SIMS \\
\hline CO20L-04 & $\begin{array}{l}\text { Cochenour } \\
\text { Mine }\end{array}$ & Drill Core & 147.425 & Quartz, Actinolite, Calcite & TRM \\
\hline MB891-01 & Marboy & Drill Core & 0.0 & $\begin{array}{l}\text { Plagioclase, Chlorite, Biotite, } \\
\text { Pyroxene, Pyrite }\end{array}$ & $\mathrm{TM}$ \\
\hline MB891-02 & Marboy & Drill Core & 0.0 & $\begin{array}{l}\text { Quartz, Plagioclase, Muscovite, } \\
\text { Chlorite }\end{array}$ & $\mathrm{TM}$ \\
\hline MB891-03 & Marboy & Drill Core & 0.0 & $\begin{array}{l}\text { Plagioclase, Hornblende, Quartz, } \\
\text { Carbonate }\end{array}$ & $\mathrm{TM}$ \\
\hline MB891-04 & Marboy & Drill Core & 10.531 & Quartz & TRM \\
\hline MB891-05 & Marboy & Drill Core & 35.219 & $\begin{array}{l}\text { Quartz, Calcite, Plagioclase, } \\
\text { Biotite/Chlorite }\end{array}$ & TRM \\
\hline MB891-06 & Marboy & Drill Core & 35.219 & Carbonate, Quartz & TRM, SIMS \\
\hline MB894-01 & Marboy & Drill Core & 0.0 & Carbonate, Quartz, Plagioclase & TRM \\
\hline MB10034-01 & Marboy & Drill Core & 0.038 & Carbonate, Quartz & TRM, CL, \\
\hline MB10034-02 & Marboy & Drill Core & 11.156 & Quartz, Carbonate & TRM, CL \\
\hline MB10034-03 & Marboy & Drill Core & 0.006 & Carbonate, Quartz & TRM, CL, SIMS \\
\hline MB10034-04 & Marboy & Drill Core & 5.575 & $\begin{array}{c}\text { Carbonate, Sercite, Plagioclase, } \\
\text { Quartz }\end{array}$ & TRM \\
\hline EB903-01 & Chevron & Drill Core & 20.0 & Quartz & TRM \\
\hline EB903-02 & Chevron & Drill Core & 0.002 & Quartz, carbonate, Chlorite & TRM, CL \\
\hline EB9010-01 & Chevron & Drill Core & 6.094 & Quartz, Carbonate, Biotite/Chlorite & TRM \\
\hline EB9012-01 & Chevron & Drill Core & 0.003 & Carbonate, Sericite, Quartz & TRM \\
\hline EB9012-02 & Chevron & Drill Core & 14.063 & & \\
\hline EB9017-01 & Chevron & Drill Core & 11.156 & Quartz, Chlorite & TRM, FI, SIMS \\
\hline EB9017-02 & Chevron & Drill Core & 0.006 & Carbonate, Quartz & TRM, FI, SIMS \\
\hline EB9022-01 & Chevron & Drill Core & 0.002 & Plagioclase, Chlorite, Quartz & $\mathrm{TM}$ \\
\hline
\end{tabular}




\begin{tabular}{|c|c|c|c|c|c|}
\hline AB117-01 & Abino & Drill Core & 0.300 & Chlorite, Biotite, Quartz & TRM \\
\hline AB117-02 & Abino & Drill Core & 0.300 & Quartz, Biotite & TRM \\
\hline AB117-03 & Abino & Drill Core & 0.300 & Quartz & TRM \\
\hline ABU35-01 & Abino & Drill Core & 9.344 & & \\
\hline ABU38-01 & Abino & Drill Core & 0.0 & Quartz, Biotite & TRM \\
\hline ABU38-02 & Abino & Drill Core & 10.334 & Quartz, Carbonate & TRM \\
\hline ABU38-03 & Abino & Drill Core & 10.344 & Quartz, Chlorite & TRM \\
\hline ABU38-04 & Abino & Drill Core & 0.938 & $\begin{array}{l}\text { Quartz, Plagioclase, Chlorite, } \\
\text { Carbonate }\end{array}$ & TRM \\
\hline ABU49-01 & Abino & Drill Core & 29.800 & Quartz & TRM, FI, SIMS \\
\hline ABU51-01 & Abino & Drill Core & 0.0 & Quartz, Muscovite, Plagioclase & TRM, FI, SIMS \\
\hline ABU51-02 & Abino & Drill Core & 20.687 & Quartz, Plagioclase, Muscovite & TRM \\
\hline ABU53-01 & Abino & Drill Core & 0.0 & & \\
\hline EB09031-01 & Duchesne & Drill Core & 9.0 & Biotite, Quartz, Chlorite & TRM, FI \\
\hline EB10040-01 & Duchesne & Drill Core & 0.019 & Chlorite, Talc, Altered Plagioclase & $\mathrm{TM}$ \\
\hline EB10040-02 & Duchesne & Drill Core & 0.028 & Quartz, Carbonate, Pyroxene & TRM, FI, SIMS \\
\hline EB10040-03 & Duchesne & Drill Core & 1.928 & Quartz, Sulphides & TRM \\
\hline EB10040-04 & Duchesne & Drill Core & 0.353 & Quartz, Biotite, Pyrite & $\mathrm{TM}$ \\
\hline EB10040-05 & Duchesne & Drill Core & 1.928 & & \\
\hline EB10048-01 & Duchesne & Drill Core & 0.0 & Pyroxene, Plagioclase, Serpentine & $\mathrm{TM}$ \\
\hline EB10048-02 & Duchesne & Drill Core & 0.013 & Chlorite, Plagioclase, Quartz & $\mathrm{TM}$ \\
\hline EB10048-03 & Duchesne & Drill Core & 58.788 & Quartz, Biotite, Actinolite & TRM, FI, SIMS \\
\hline EB10048-05 & Duchesne & Drill Core & 0.478 & & \\
\hline EB10048-06 & Duchesne & Drill Core & 0.478 & & \\
\hline SG11-AR01 & Abino & Surface & - & Fuchsite, Quartz & TRM \\
\hline SG11-AR02 & Abino & Surface & - & Quartz, Sericite & TRM \\
\hline SG11-AR03 & Abino & Surface & - & & \\
\hline SG11-006 & Cochenour & Surface & & Carbonate, Chlorite, Biotite & $\mathrm{TM}$ \\
\hline SG11-017 & Marboy & Surface & & Chlorite, Biotite, Pyroxene & $\mathrm{TM}$ \\
\hline SG11-075 & Abino & Surface & & Quartz, Carbonate & \\
\hline
\end{tabular}




\begin{tabular}{|c|c|c|c|c|}
\hline SG11-102 & Abino & Surface & $\begin{array}{l}\text { Quartz, Plagioclase, } \\
\text { Biotite/Muscovite }\end{array}$ & TM \\
\hline SG11-127 & Beatrice & Surface & Plagioclase, Quartz, Biotite & TM \\
\hline SG11-163 & East Bay North & Surface & Quartz, Sericite, Microcline & $\mathrm{TM}$ \\
\hline SG11-171A & Tuckers Knob & Surface & Carbonate, Quartz & TRM \\
\hline SG11-171C & Tuckers Knob & Surface & Carbonate, Chlorite, Quartz, & TRM \\
\hline SG11-171D & Tuckers Knob & Surface & Carbonate, Quartz, Chlorite, Biotite & TRM, CL, FI, SIMS \\
\hline SG11-171E & Tuckers Knob & Surface & Carbonate, Tremolite & TRM \\
\hline SG11-173 & McFinley & Surface & Plagioclase, Biotite, Carbonate & TM \\
\hline SG11-174A1 & Marboy & Surface & $\begin{array}{l}\text { Carbonate, Tourmaline, Quartz, } \\
\text { Chlorite }\end{array}$ & TRM, FI \\
\hline SG11-174A2 & Marboy & Surface & $\begin{array}{c}\text { Tourmaline, Quartz, Calcite, } \\
\text { Plagioclase }\end{array}$ & TRM \\
\hline SG11-174B & Marboy & Surface & Carbonate, Quartz, Biotite & TRM \\
\hline SG11-175A & Tuckers Knob & Surface & Quartz, Chlorite, Carbonate & TM \\
\hline SG11-175B & Tuckers Knob & Surface & Orthoclase, Quartz & TM \\
\hline SG11-175C & Tuckers Knob & Surface & Quartz, Amphibole, Chlorite & TM \\
\hline SG11-175D1 & Tuckers Knob & Surface & Quartz & TRM \\
\hline SG11-175D2 & Tuckers Knob & Surface & Carbonate, Quartz & TRM, CL \\
\hline SG11-175E & Tuckers Knob & Surface & Carbonate, Quartz & TRM, CL \\
\hline SG11-175F & Tuckers Knob & Surface & Carbonate, Quartz & TRM \\
\hline SG11-175J & Tuckers Knob & Surface & Carbonate, Quartz & TRM \\
\hline SG11-176A & McFinley & Surface & Biotite, Plagioclase, Quartz, Calcite & TM \\
\hline SG11-176B & McFinley & Surface & Carbonate & TRM \\
\hline SG11-176D & McFinley & Surface & Carbonate, Biotite, Quartz & TM \\
\hline SG11-177A & Abino & Surface & Carbonate, Quartz, Albite & TRM \\
\hline SG11-177B & Abino & Surface & $\begin{array}{c}\text { Carbonate, Quartx, Albite, } \\
\text { Tourmaline }\end{array}$ & TRM \\
\hline SG11-178A & Abino & Surface & Tourmaline, Quartz & TRM, XRD, EMP \\
\hline SG11-178B & Abino & Surface & $\begin{array}{l}\text { Quartz, Carbonate, Chlorite, } \\
\text { plagioclase }\end{array}$ & TRM \\
\hline SG11-178C & Abino & Surface & Quartz, Carbonate, Biotite, Chlorite & TRM \\
\hline SG11-179 & McFinley & Surface & Quartz, carbonate, Chlorite & TRM \\
\hline
\end{tabular}




\begin{tabular}{cc|cc}
\hline \multicolumn{3}{c}{ Table A2 - Thin Section Summary Chart Legend } \\
\hline Symbol & Mineral & Symbol & Mineral \\
\hline Qtz & quartz & Py & pyrite \\
Plag & plagioclase & Po & pyrrhotite \\
Q-C & quartz- & Apy & arsenopyrite \\
& carbonate & & \\
Bio & Biotite & $\mathrm{Cpy}$ & Chalcopyrite \\
Ser & sericite & $\mathrm{Sp}$ & Sphalerite \\
Fch & fuchsite & $\mathrm{Mt}$ & Magnetite \\
Bio & biotite & $\mathrm{Ilm}$ & ilmenite \\
$\mathrm{Chl}$ & chlorite & $\mathrm{Mt}$ & magnetite \\
$\mathrm{Ab}$ & albite & $\mathrm{Sch}$ & scheelite \\
$\mathrm{Pyx}$ & pyroxene & $\mathrm{Ttn}$ & titanite \\
$\mathrm{Srp}$ & serpentine & $\mathrm{Rt}$ & rutile \\
$\mathrm{Tour}$ & tourmaline & $\mathrm{St}$ & stibnite \\
$\mathrm{Dol}$ & dolomite & $\mathrm{Mb}$ & molybdenite \\
$\mathrm{Crb}$ & carbonate & $\mathrm{Ga}$ & Galena \\
$\mathrm{Act}$ & actinolite & $\mathrm{Tet}$ & tetrahedrite \\
$\mathrm{Ja}$ & jamesonite & $\mathrm{Zr}$ & zircon \\
$\mathrm{Au} / \mathrm{Vg}$ & Gold & $\mathrm{Ag}$ & Silver \\
\hline
\end{tabular}

Legend for image annotations and table 5.2 mineralogy abbreviations 
Appendix B

Powder X-ray Diffraction Spectra 
Figure B.1 - Powder x-ray diffraction spectrum of sample SG11-175E carbonate, Tuckers Knob, Red Lake, Ontario

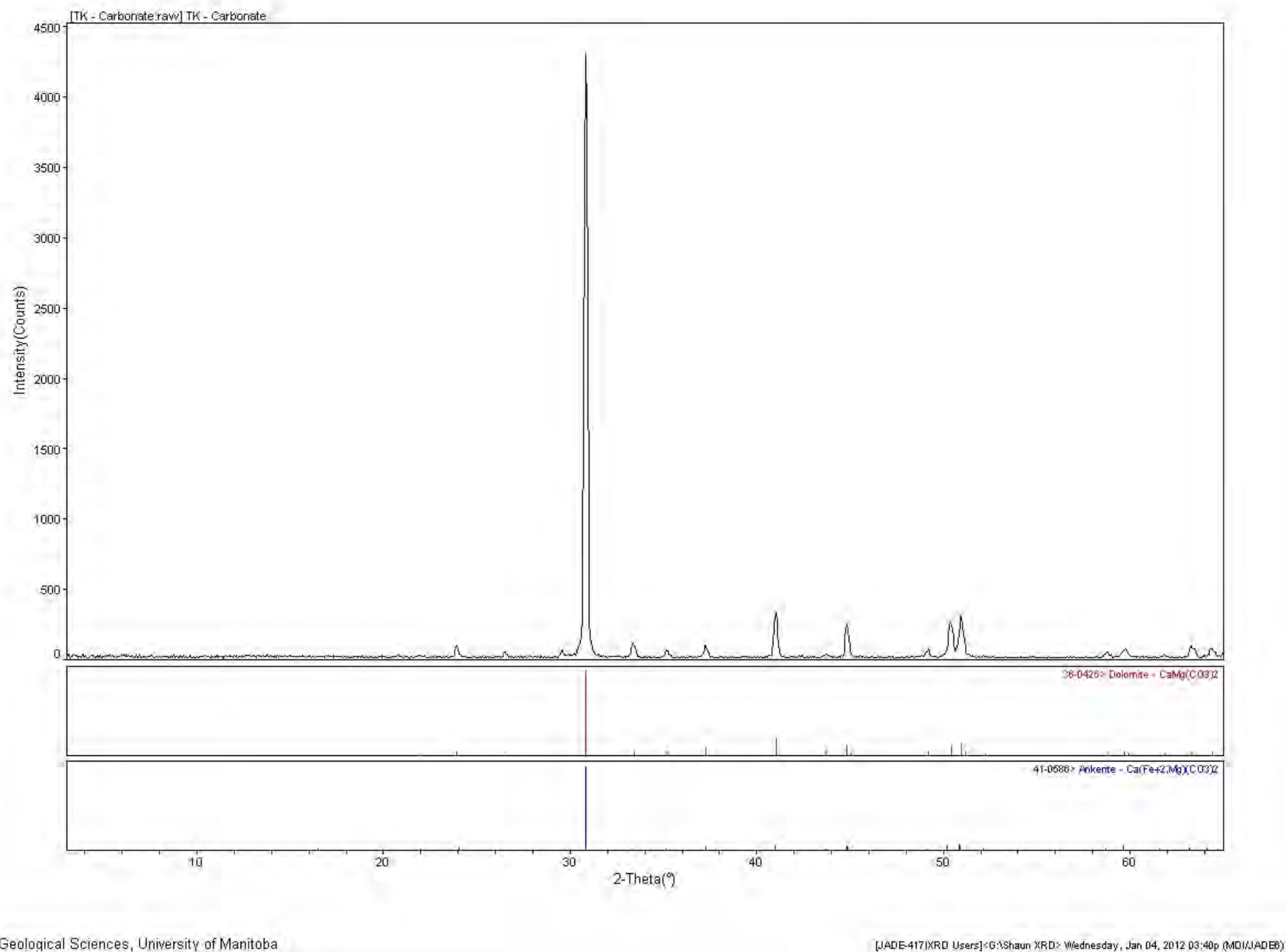


Figure B.2 - Powder x-ray diffraction spectrum of sample MB10035 carbonate, Marboy Deposit, Red Lake, Ontario

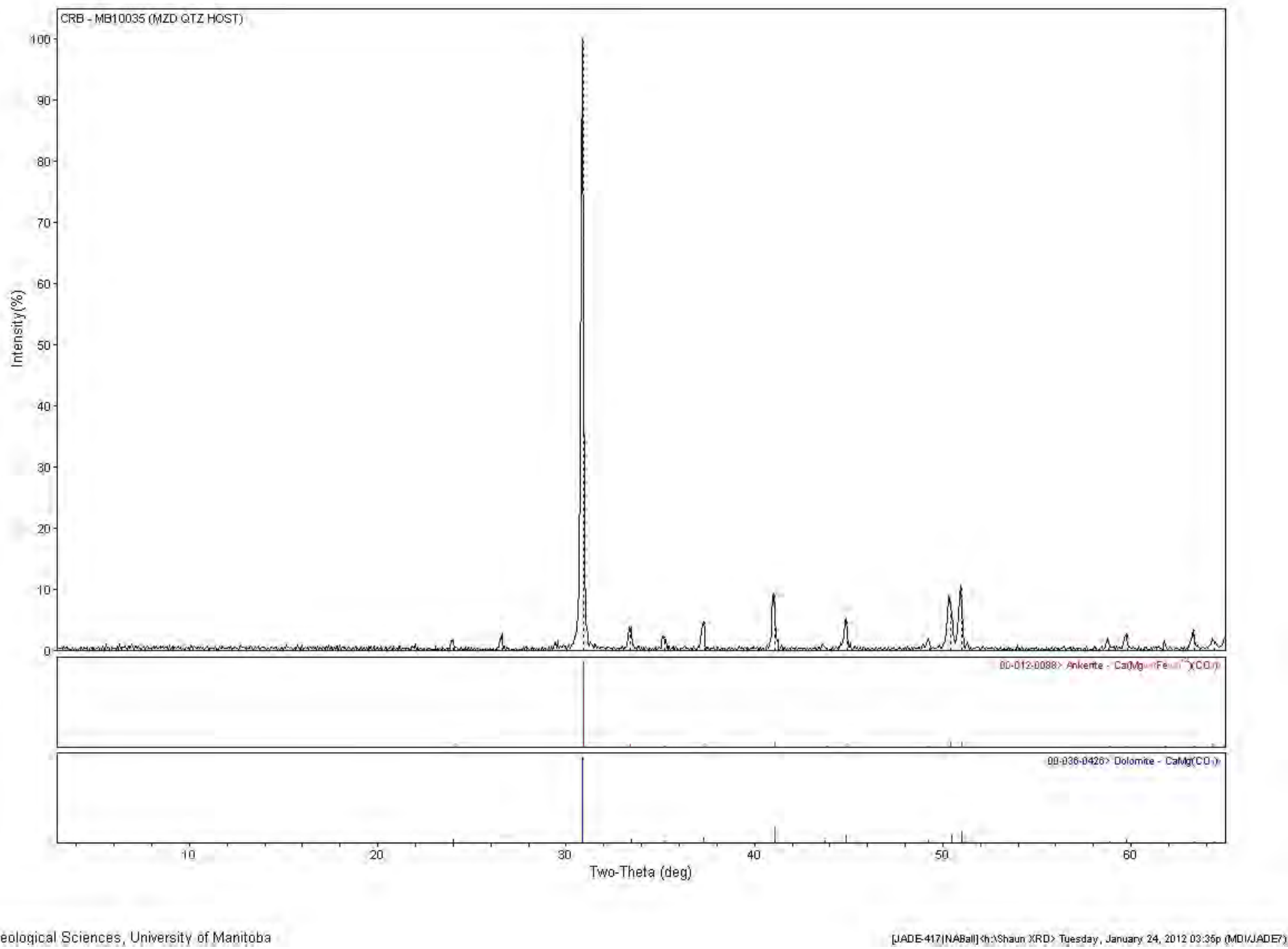


Figure B.3 - Powder x-ray diffraction spectrum of sample MB89-4 quartz/carbonate, Marboy Deposit, Red Lake, Ontario

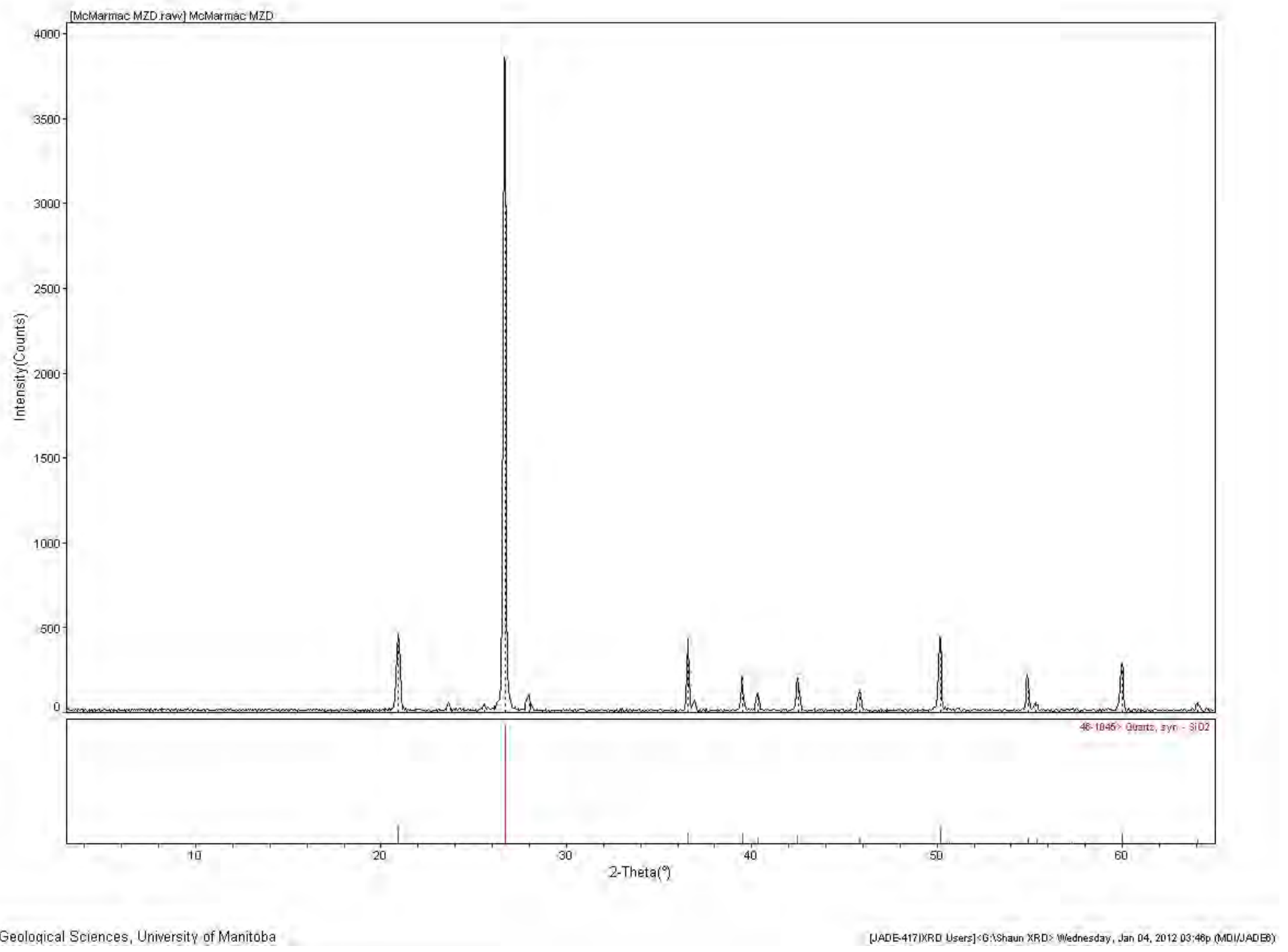


Figure B.4 - Powder x-ray diffraction spectrum of sample SG11-178A black line fault, Abino Property, Red Lake, Ontario

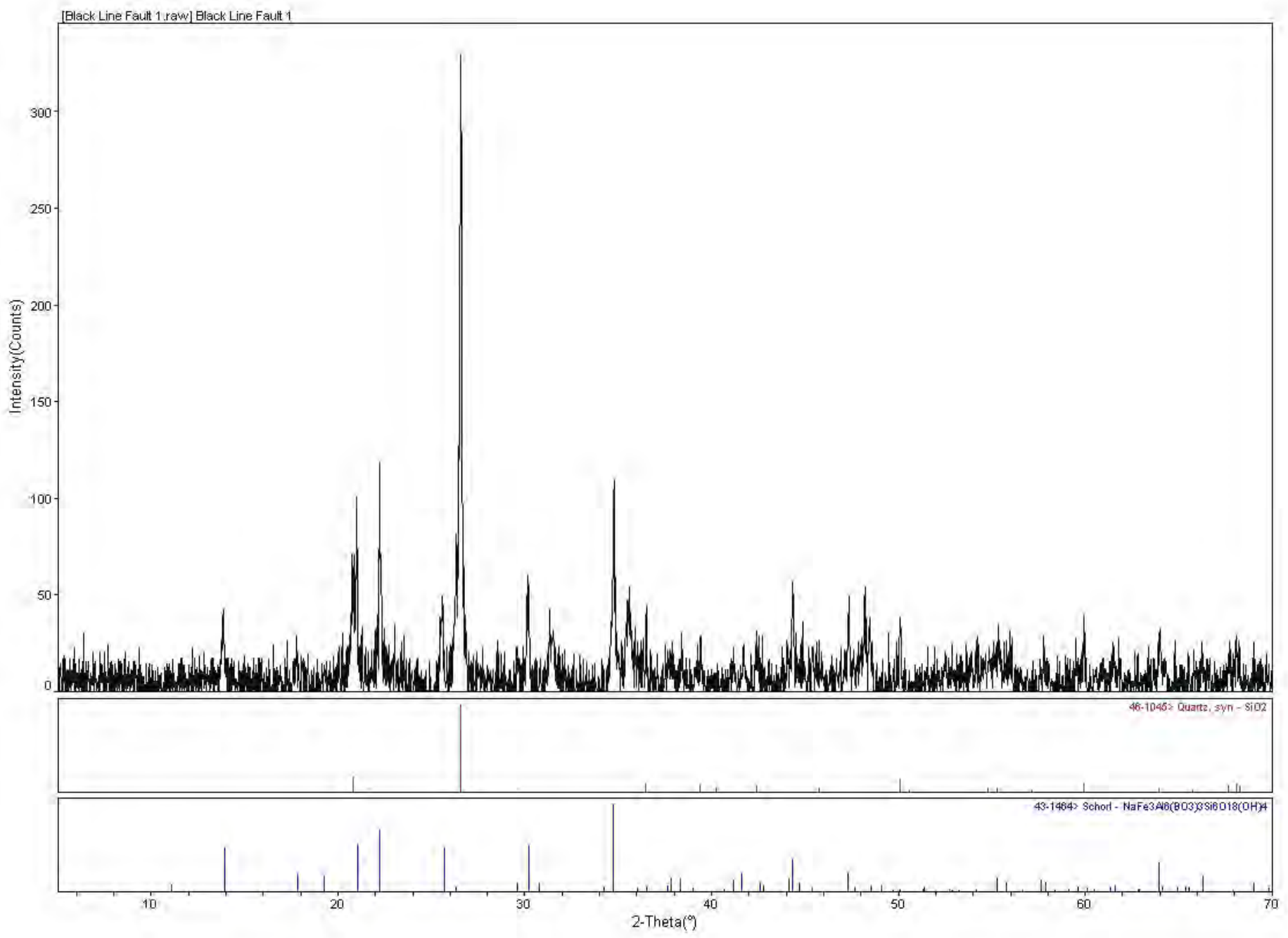

Dept. of Geological Sciences, University of Manitoba 
Figure B.5 - Powder x-ray diffraction spectrum of sample SG11-AR01 fuchsite zone, Abino Property, Red Lake, Ontario

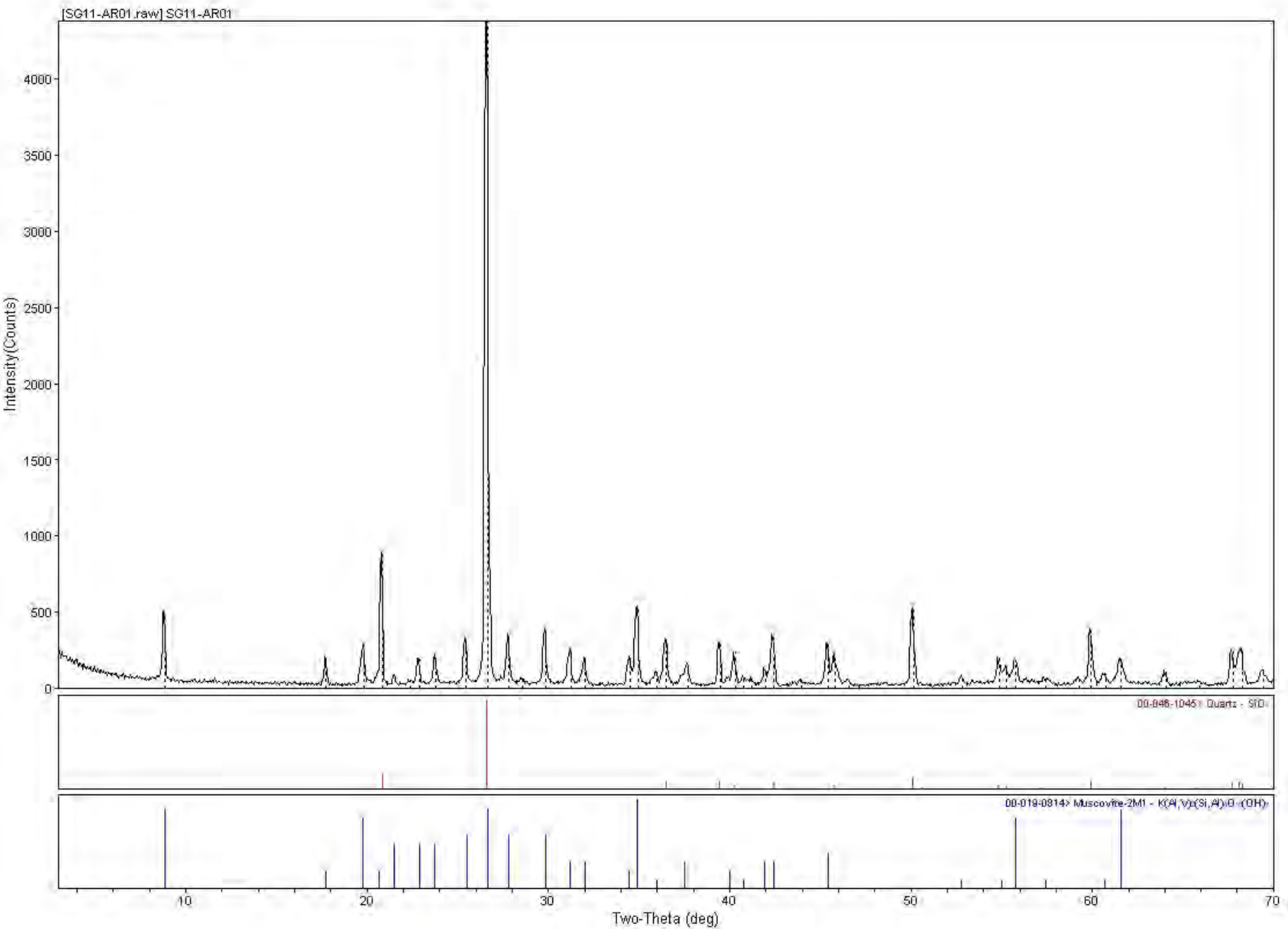

Dept. of Geological Sciences, University of Manitaba 
Figure B.6 - Powder x-ray diffraction spectrum of sample SG11-AR02 sericite zone, Abino Property, Red Lake, Ontario

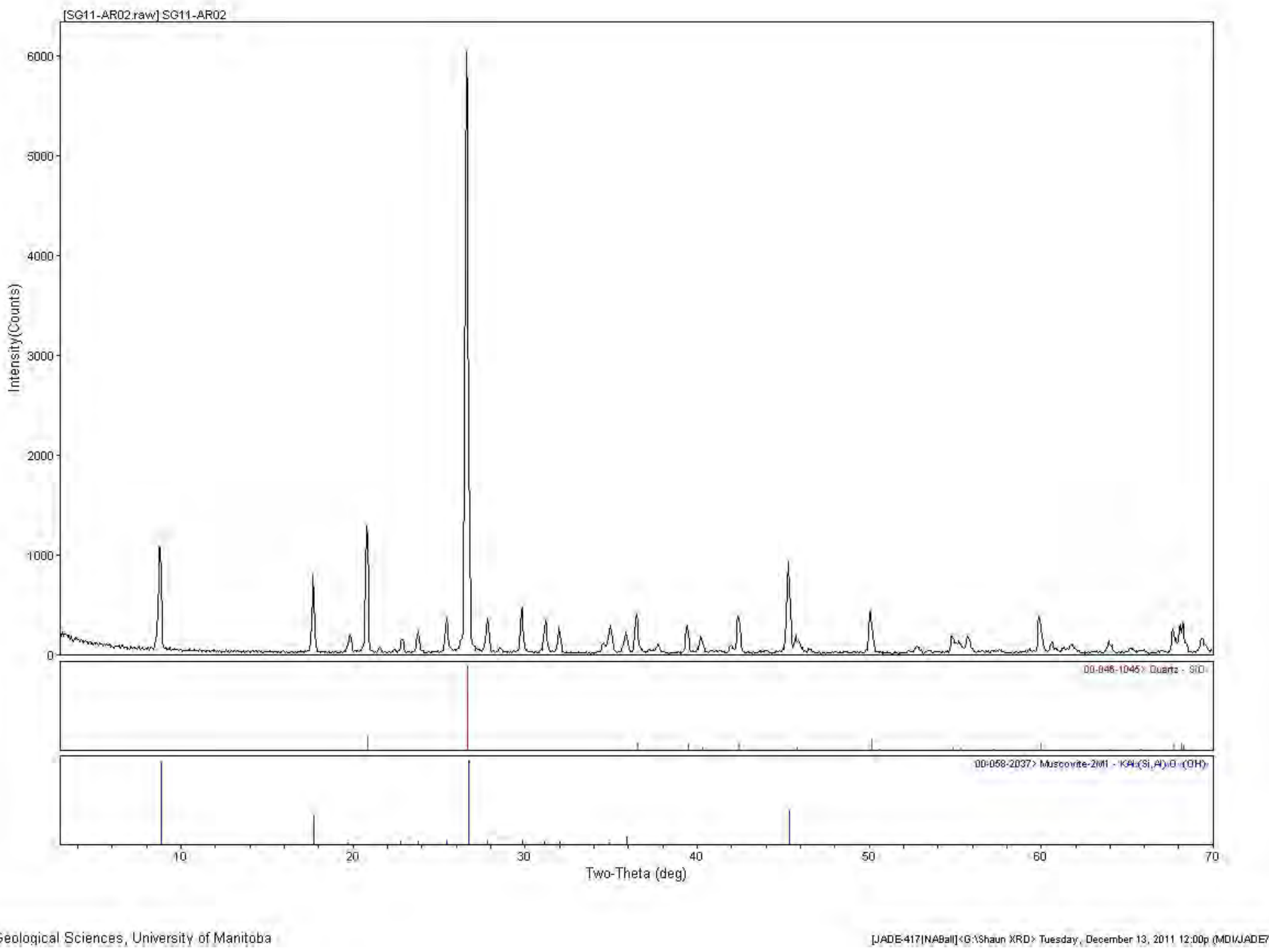


Figure B.7 - Powder x-ray diffraction spectrum of sample SG11-AR03 biotite zone, Abino Property, Red Lake, Ontario

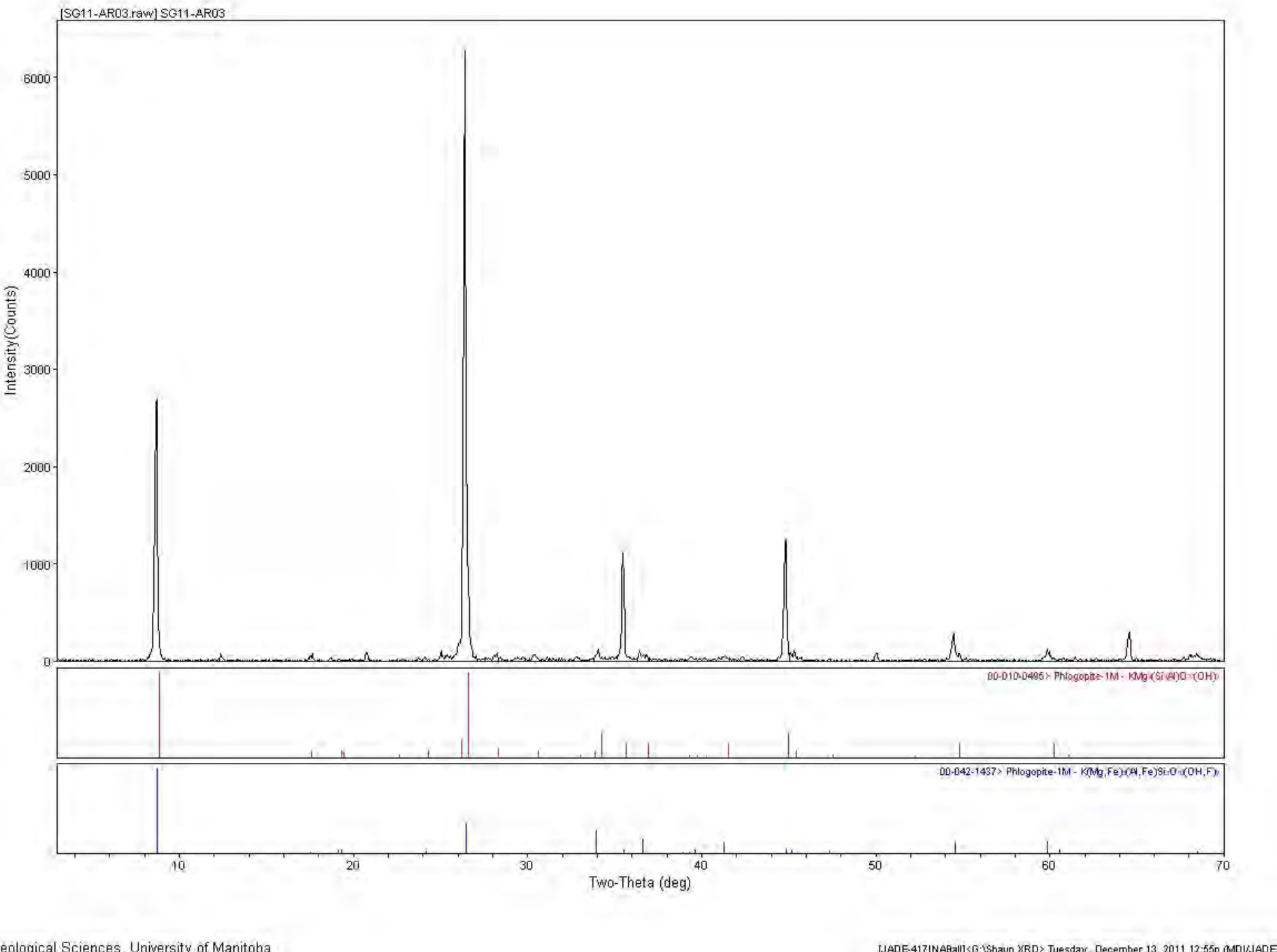


Appendix C

Electron Microprobe Analysis 
Table C.1 - Electron microprobe analyses on tourmalines from quartz-tourmaline veins - Element weight \%

\section{Element Weight \%}

\begin{tabular}{|c|c|c|c|c|c|c|c|c|c|c|c|c|c|c|c|c|c|}
\hline Sample \# & $\mathrm{Na}$ & Al & $\mathrm{Si}$ & $\mathbf{F}$ & $\mathrm{Mg}$ & K & $\mathrm{Ca}$ & $\mathrm{Fe}$ & $\mathrm{Mn}$ & $\mathrm{Ti}$ & v & $\mathrm{Cr}$ & B & 0 & H & Total & Mineral \\
\hline SG11-178A_1 & 1.15 & 16.06 & 20.88 & 0.00 & 3.52 & 0.02 & 0.15 & 3.88 & 0.00 & 0.18 & 0.01 & 0.03 & 2.73 & 48.17 & 0.32 & 97.10 & Elbaite \\
\hline SG11-178A_2 & 1.26 & 16.14 & 20.84 & 0.07 & 3.42 & 0.01 & 0.18 & 4.29 & 0.01 & 0.32 & 0.01 & 0.04 & 2.52 & 50.55 & 0.33 & 100.00 & Elbaite \\
\hline SG11-178A_3 & 1.28 & 16.55 & 19.93 & 0.10 & 3.56 & 0.01 & 0.21 & 4.46 & 0.00 & 0.20 & 0.03 & 0.03 & 2.87 & 50.48 & 0.30 & 100.00 & Elbaite \\
\hline SG11-178A_4 & 1.16 & 16.40 & 20.11 & 0.02 & 3.51 & 0.01 & 0.20 & 4.43 & 0.00 & 0.21 & 0.03 & 0.04 & 2.92 & 50.66 & 0.31 & 100.00 & Elbaite \\
\hline SG11-178A_5 & 1.38 & 17.82 & 17.89 & 0.15 & 3.83 & 0.01 & 0.18 & 4.64 & 0.01 & 0.26 & 0.00 & 0.03 & 2.99 & 50.43 & 0.37 & 100.00 & Elbaite \\
\hline SG11-178A_6 & 1.38 & 17.14 & 18.86 & 0.00 & 3.70 & 0.01 & 0.22 & 4.49 & 0.01 & 0.20 & 0.03 & 0.02 & 2.91 & 50.65 & 0.38 & 100.00 & Elbaite \\
\hline SG11-178A_7 & 0.18 & 1.76 & 43.79 & 0.00 & 0.38 & 0.01 & 0.06 & 0.52 & 0.02 & 0.02 & 0.01 & 0.02 & 0.17 & 52.99 & 0.08 & 100.00 & Elbaite \\
\hline SG11-178A_8 & 0.59 & 19.43 & 22.19 & 0.00 & 0.32 & 8.64 & 0.01 & 0.87 & 0.01 & 0.23 & 0.00 & 0.01 & 0.00 & 0.28 & 47.40 & 100.00 & Elbaite \\
\hline SG11-178A_9 & 1.15 & 14.43 & 23.55 & 0.12 & 3.13 & 0.02 & 0.15 & 3.85 & 0.00 & 0.20 & 0.01 & 0.01 & 2.57 & 0.19 & 50.62 & 100.00 & Elbaite \\
\hline SG11-178A_10 & 1.38 & 17.25 & 19.12 & 0.16 & 3.64 & 0.01 & 0.20 & 4.54 & 0.02 & 0.29 & 0.01 & 0.03 & 2.95 & 0.25 & 50.14 & 100.00 & Elbaite \\
\hline SG11-178A_11 & 1.08 & 13.35 & 25.14 & 0.11 & 2.86 & 0.01 & 0.13 & 3.49 & 0.00 & 0.43 & 0.00 & 0.02 & 2.60 & 0.10 & 50.68 & 100.00 & Elbaite \\
\hline SG11-178A_12 & 1.31 & 16.27 & 20.55 & 0.18 & 3.47 & 0.02 & 0.14 & 4.19 & 0.00 & 0.40 & 0.04 & 0.05 & 2.44 & 0.37 & 50.57 & 100.00 & Elbaite \\
\hline SG11-174A2_1 & 0.00 & 0.01 & 0.03 & 0.00 & 0.36 & 0.00 & 43.35 & 1.38 & 0.54 & 0.01 & 0.00 & 0.00 & 0.00 & 4.05 & 50.27 & 100.00 & Dravite \\
\hline SG11-174A2_2 & 2.06 & 15.23 & 16.69 & 0.07 & 3.17 & 0.04 & 0.16 & 10.41 & 0.01 & 0.40 & 0.11 & 0.03 & 3.12 & 0.32 & 48.19 & 100.00 & Dravite \\
\hline SG11-174A2_3 & 2.00 & 15.16 & 16.66 & 0.00 & 3.15 & 0.04 & 0.16 & 10.51 & 0.01 & 0.50 & 0.10 & 0.02 & 3.10 & 0.34 & 48.26 & 100.00 & Dravite \\
\hline SG11-174A2_4 & 2.12 & 15.10 & 16.54 & 0.10 & 3.16 & 0.03 & 0.14 & 10.69 & 0.00 & 0.46 & 0.10 & 0.03 & 2.94 & 0.39 & 48.22 & 100.00 & Dravite \\
\hline SG11-174A2_5 & 2.06 & 14.84 & 16.76 & 0.00 & 3.26 & 0.03 & 0.16 & 10.85 & 0.00 & 0.51 & 0.10 & 0.03 & 3.10 & 0.30 & 48.00 & 100.00 & Dravite \\
\hline SG11-174A2_6 & 2.11 & 15.12 & 16.78 & 0.00 & 3.27 & 0.04 & 0.14 & 10.50 & 0.01 & 0.46 & 0.11 & 0.03 & 3.07 & 0.30 & 48.07 & 100.00 & Dravite \\
\hline SG11-174A2_7 & 0.02 & 0.00 & 1.05 & 0.00 & 0.66 & 0.00 & 32.74 & 12.45 & 0.74 & 0.00 & 0.02 & 0.00 & 0.00 & 3.78 & 48.53 & 100.00 & Dravite \\
\hline SG11-174A2_8 & 2.03 & 15.27 & 16.80 & 0.00 & 3.28 & 0.03 & 0.12 & 10.65 & 0.02 & 0.27 & 0.08 & 0.02 & 2.99 & 0.32 & 48.11 & 100.00 & Dravite \\
\hline SG11-174A2_9 & 2.11 & 15.75 & 16.78 & 0.04 & 3.39 & 0.04 & 0.13 & 10.09 & 0.00 & 0.27 & 0.05 & 0.04 & 3.14 & 0.22 & 47.95 & 100.00 & Dravite \\
\hline
\end{tabular}


Table C.1 (Cont)

\begin{tabular}{|c|c|c|c|c|c|c|c|c|c|c|c|c|c|c|c|c|c|}
\hline Sample \# & $\mathrm{Na}$ & Al & $\mathrm{Si}$ & $\mathbf{F}$ & $\mathrm{Mg}$ & K & $\mathrm{Ca}$ & $\mathrm{Fe}$ & $M n$ & $\mathrm{Ti}$ & v & $\mathrm{Cr}$ & B & 0 & H & Total & Mineral \\
\hline SG11-177B_1 & 0.38 & 0.03 & 0.00 & 0.02 & 0.01 & 0.18 & 0.47 & 0.31 & 0.00 & 55.86 & 1.02 & 0.68 & 0.06 & 0.25 & 40.74 & 100.00 & Elbaite \\
\hline SG11-177B_2 & 1.05 & 17.88 & 17.28 & 0.00 & 4.02 & 0.01 & 0.00 & 5.61 & 0.00 & 0.02 & 0.00 & 0.00 & 2.83 & 0.53 & 50.75 & 100.00 & Elbaite \\
\hline SG11-177B_3 & 1.63 & 17.63 & 17.03 & 0.65 & 3.80 & 0.03 & 0.06 & 5.88 & 0.04 & 0.24 & 0.03 & 0.01 & 2.65 & 0.49 & 49.84 & 100.00 & Elbaite \\
\hline SG11-177B_4 & 1.38 & 18.14 & 17.15 & 0.00 & 3.56 & 0.02 & 0.06 & 5.66 & 0.00 & 0.27 & 0.05 & 0.02 & 3.02 & 0.40 & 50.27 & 100.00 & Elbaite \\
\hline SG11-177B_5 & 0.00 & 0.01 & 46.54 & 0.04 & 0.00 & 0.00 & 0.00 & 0.05 & 0.02 & 0.00 & 0.01 & 0.01 & 0.00 & 0.03 & 53.29 & 100.00 & Elbaite \\
\hline SG11-177B_6 & 1.25 & 17.91 & 17.34 & 0.00 & 4.08 & 0.02 & 0.09 & 5.44 & 0.00 & 0.09 & 0.07 & 0.00 & 2.46 & 0.59 & 50.64 & 100.00 & Elbaite \\
\hline SG11-177B_7 & 1.55 & 17.28 & 17.16 & 0.02 & 4.05 & 0.02 & 0.01 & 5.80 & 0.00 & 0.03 & 0.11 & 0.15 & 2.71 & 0.58 & 50.53 & 100.00 & Elbaite \\
\hline SG11-177B_8 & 1.64 & 17.67 & 17.23 & 0.35 & 3.86 & 0.01 & 0.05 & 5.50 & 0.01 & 0.26 & 0.03 & 0.00 & 3.06 & 0.37 & 49.98 & 100.00 & Elbaite \\
\hline SG11-177B_9 & 0.94 & 17.79 & 17.41 & 0.11 & 4.08 & 0.01 & 0.01 & 5.53 & 0.00 & 0.01 & 0.03 & 0.03 & 2.56 & 0.61 & 50.86 & 100.00 & Elbaite \\
\hline SG11-174B_1 & 1.46 & 4.79 & 3.59 & 0.00 & 2.88 & 0.01 & 0.04 & 10.05 & 0.00 & 0.08 & 0.09 & 0.00 & 1.50 & 6.54 & 68.98 & 100.00 & Dravite \\
\hline SG11-174B_2 & 2.16 & 14.49 & 16.73 & 0.12 & 3.73 & 0.06 & 0.19 & 10.39 & 0.02 & 0.55 & 0.08 & 0.03 & 3.12 & 0.31 & 48.02 & 100.00 & Dravite \\
\hline SG11-174B_3 & 2.09 & 13.23 & 16.51 & 0.11 & 3.67 & 0.05 & 0.22 & 11.68 & 0.01 & 1.54 & 0.14 & 0.02 & 3.32 & 0.20 & 47.21 & 100.00 & Dravite \\
\hline SG11-174B_4 & 2.18 & 14.31 & 16.53 & 0.12 & 3.82 & 0.06 & 0.21 & 10.59 & 0.02 & 0.50 & 0.11 & 0.01 & 2.77 & 0.48 & 48.31 & 100.00 & Dravite \\
\hline SG11-174B_5 & 0.01 & 0.00 & 0.03 & 0.00 & 0.47 & 0.02 & 45.55 & 1.53 & 0.42 & 0.01 & 0.00 & 0.00 & 0.00 & 3.68 & 48.28 & 100.00 & Dravite \\
\hline SG11-174B_6 & 2.40 & 13.54 & 16.48 & 0.06 & 4.07 & 0.21 & 0.12 & 11.46 & 0.01 & 0.24 & 0.10 & 0.00 & 4.02 & 0.05 & 47.25 & 100.00 & Dravite \\
\hline SG11-174B_7 & 2.22 & 13.47 & 16.67 & 0.00 & 4.11 & 0.06 & 0.08 & 12.10 & 0.04 & 0.25 & 0.09 & 0.01 & 2.56 & 0.50 & 47.85 & 100.00 & Dravite \\
\hline SG11-174B_8 & 2.18 & 12.91 & 16.34 & 0.00 & 3.66 & 0.08 & 0.18 & 13.22 & 0.02 & 0.76 & 0.12 & 0.04 & 3.15 & 0.29 & 47.04 & 100.00 & Dravite \\
\hline SG11-174B_9 & 2.51 & 13.85 & 16.39 & 0.00 & 3.71 & 0.27 & 0.21 & 10.91 & 0.00 & 0.68 & 0.11 & 0.00 & 4.64 & 0.00 & 48.38 & 101.65 & Dravite \\
\hline
\end{tabular}


Table C2 - Electron microprobe analyses on tourmalines from quartz-tourmaline veins - Oxide weight \%

\section{Oxide Weight \%}

\begin{tabular}{|c|c|c|c|c|c|c|c|c|c|c|c|c|c|c|c|c|}
\hline Sample \# & $\mathrm{Na2O}$ & Al203 & $\mathrm{SiO} 2$ & $\mathbf{F}$ & MgO & K2O & $\mathrm{CaO}$ & $\mathrm{FeO}$ & $\mathrm{MnO}$ & TiO2 & V2O3 & Cr2O3 & B2O3 & $\mathrm{H} 2 \mathrm{O}$ & Total & Mineral \\
\hline SG11-178A_1 & 1.55 & 30.34 & 44.67 & 0.00 & 5.85 & 0.02 & 0.21 & 4.99 & 0.00 & 0.30 & 0.02 & 0.04 & 8.79 & & 96.78 & Elbaite \\
\hline SG11-178A_2 & 1.70 & 30.50 & 44.59 & 0.07 & 5.68 & 0.02 & 0.25 & 5.53 & 0.01 & 0.53 & 0.02 & 0.05 & 8.12 & 2.93 & 100.00 & Elbaite \\
\hline SG11-178A_3 & 1.73 & 31.27 & 42.63 & 0.10 & 5.91 & 0.02 & 0.29 & 5.74 & 0.00 & 0.33 & 0.05 & 0.04 & 9.24 & 2.67 & 100.00 & Elbaite \\
\hline SG11-178A_4 & 1.56 & 30.98 & 43.01 & 0.02 & 5.83 & 0.01 & 0.28 & 5.70 & 0.00 & 0.35 & 0.04 & 0.05 & 9.42 & 2.74 & 100.00 & Elbaite \\
\hline SG11-178A_5 & 1.86 & 33.68 & 38.28 & 0.15 & 6.36 & 0.01 & 0.25 & 5.97 & 0.01 & 0.43 & 0.00 & 0.05 & 9.63 & 3.33 & 100.00 & Elbaite \\
\hline SG11-178A_6 & 1.86 & 32.39 & 40.34 & 0.00 & 6.14 & 0.02 & 0.31 & 5.77 & 0.01 & 0.33 & 0.05 & 0.03 & 9.38 & 3.38 & 100.00 & Elbaite \\
\hline SG11-178A_7 & 0.24 & 3.33 & 93.69 & 0.00 & 0.63 & 0.01 & 0.08 & 0.67 & 0.02 & 0.04 & 0.01 & 0.03 & 0.55 & 0.70 & 100.00 & Elbaite \\
\hline SG11-178A_8 & 0.80 & 36.71 & 47.47 & 0.00 & 0.54 & 10.41 & 0.01 & 1.12 & 0.02 & 0.39 & 0.00 & 0.02 & 0.00 & 2.52 & 100.00 & Elbaite \\
\hline SG11-178A_9 & 1.55 & 27.27 & 50.39 & 0.12 & 5.19 & 0.02 & 0.21 & 4.95 & 0.00 & 0.33 & 0.01 & 0.01 & 8.27 & 1.67 & 100.00 & Elbaite \\
\hline SG11-178A_10 & 1.86 & 32.60 & 40.91 & 0.16 & 6.03 & 0.01 & 0.28 & 5.84 & 0.02 & 0.49 & 0.02 & 0.05 & 9.49 & 2.24 & 100.00 & Elbaite \\
\hline SG11-178A_11 & 1.46 & 25.23 & 53.79 & 0.11 & 4.75 & 0.01 & 0.18 & 4.49 & 0.00 & 0.71 & 0.00 & 0.03 & 8.36 & 0.89 & 100.00 & Elbaite \\
\hline SG11-178A_12 & 1.77 & 30.75 & 43.97 & 0.18 & 5.75 & 0.03 & 0.19 & 5.38 & 0.00 & 0.66 & 0.06 & 0.07 & 7.86 & 3.32 & 100.00 & Elbaite \\
\hline SG11-174A2_1 & 0.00 & 0.01 & 0.06 & 0.00 & 0.60 & 0.00 & 60.65 & 1.78 & 0.70 & 0.02 & 0.00 & 0.00 & 0.00 & 36.18 & 100.00 & Dravite \\
\hline SG11-174A2_2 & 2.78 & 28.78 & 35.71 & 0.07 & 5.26 & 0.04 & 0.22 & 13.39 & 0.01 & 0.67 & 0.16 & 0.04 & 10.04 & 2.84 & 100.00 & Dravite \\
\hline SG11-174A2_3 & 2.70 & 28.64 & 35.65 & 0.00 & 5.22 & 0.05 & 0.22 & 13.52 & 0.01 & 0.84 & 0.14 & 0.03 & 10.00 & 3.00 & 100.00 & Dravite \\
\hline SG11-174A2_4 & 2.85 & 28.52 & 35.39 & 0.10 & 5.23 & 0.04 & 0.20 & 13.75 & 0.00 & 0.76 & 0.14 & 0.04 & 9.48 & 3.50 & 100.00 & Dravite \\
\hline SG11-174A2_5 & 2.78 & 28.04 & 35.86 & 0.00 & 5.40 & 0.04 & 0.22 & 13.96 & 0.00 & 0.85 & 0.15 & 0.04 & 9.97 & 2.68 & 100.00 & Dravite \\
\hline SG11-174A2_6 & 2.84 & 28.56 & 35.90 & 0.00 & 5.43 & 0.04 & 0.20 & 13.51 & 0.01 & 0.76 & 0.15 & 0.04 & 9.87 & 2.67 & 100.00 & Dravite \\
\hline SG11-174A2_7 & 0.03 & 0.01 & 2.24 & 0.00 & 1.10 & 0.00 & 45.82 & 16.01 & 0.95 & 0.00 & 0.03 & 0.00 & 0.00 & 33.81 & 100.00 & Dravite \\
\hline SG11-174A2_8 & 2.73 & 28.86 & 35.95 & 0.00 & 5.44 & 0.04 & 0.17 & 13.71 & 0.02 & 0.44 & 0.12 & 0.03 & 9.62 & 2.87 & 100.00 & Dravite \\
\hline SG11-174A2_9 & 2.84 & 29.75 & 35.90 & 0.04 & 5.63 & 0.05 & 0.19 & 12.98 & 0.00 & 0.45 & 0.07 & 0.06 & 10.11 & 1.94 & 100.00 & Dravite \\
\hline
\end{tabular}


Table C2 (Cont)

\begin{tabular}{|c|c|c|c|c|c|c|c|c|c|c|c|c|c|c|c|c|}
\hline Sample \# & $\mathrm{Na2O}$ & Al203 & $\mathrm{SiO2}$ & $\mathbf{F}$ & MgO & $\mathrm{K} 2 \mathrm{O}$ & $\mathrm{CaO}$ & $\mathrm{FeO}$ & MnO & TiO2 & V2O3 & $\mathrm{Cr} 2 \mathrm{O3}$ & B2O3 & $\mathrm{H} 2 \mathrm{O}$ & Total & Minera \\
\hline SG11-177B_1 & 0.51 & 0.05 & 0.00 & 0.02 & 0.01 & 0.22 & 0.66 & 0.39 & 0.00 & 93.17 & 1.50 & 0.99 & 0.20 & 2.27 & 100.00 & Elbaite \\
\hline SG11-177B_2 & 1.41 & 33.79 & 36.98 & 0.00 & 6.67 & 0.02 & 0.00 & 7.21 & 0.00 & 0.03 & 0.01 & 0.00 & 9.13 & 4.75 & 100.00 & Elbaite \\
\hline SG11-177B_3 & 2.20 & 33.30 & 36.43 & 0.65 & 6.30 & 0.04 & 0.08 & 7.56 & 0.05 & 0.40 & 0.04 & 0.02 & 8.53 & 4.39 & 100.00 & Elbaite \\
\hline SG11-177B_4 & 1.86 & 34.28 & 36.70 & 0.00 & 5.90 & 0.02 & 0.08 & 7.28 & 0.00 & 0.46 & 0.07 & 0.03 & 9.72 & 3.61 & 100.00 & Elbaite \\
\hline SG11-177B_5 & 0.00 & 0.02 & 99.58 & 0.04 & 0.00 & 0.01 & 0.00 & 0.07 & 0.02 & 0.00 & 0.01 & 0.01 & 0.00 & 0.25 & 100.00 & Elbaite \\
\hline SG11-177B_6 & 1.69 & 33.85 & 37.09 & 0.00 & 6.77 & 0.02 & 0.13 & 7.00 & 0.00 & 0.15 & 0.11 & 0.01 & 7.92 & 5.27 & 100.00 & Elbaite \\
\hline SG11-177B_7 & 2.10 & 32.65 & 36.71 & 0.02 & 6.71 & 0.03 & 0.02 & 7.46 & 0.00 & 0.06 & 0.16 & 0.22 & 8.71 & 5.16 & 100.00 & Elbaite \\
\hline SG11-177B_8 & 2.21 & 33.38 & 36.86 & 0.35 & 6.40 & 0.01 & 0.07 & 7.07 & 0.01 & 0.43 & 0.04 & 0.00 & 9.86 & 3.31 & 100.00 & Elbaite \\
\hline SG11-177B_9 & 1.27 & 33.62 & 37.24 & 0.11 & 6.77 & 0.01 & 0.02 & 7.11 & 0.00 & 0.02 & 0.05 & 0.05 & 8.24 & 5.49 & 100.00 & Elbaite \\
\hline SG11-174B_1 & 1.97 & 9.05 & 7.69 & 0.00 & 4.78 & 0.02 & 0.05 & 12.92 & 0.00 & 0.13 & 0.13 & 0.00 & 4.81 & 58.46 & 100.00 & Dravite \\
\hline SG11-174B_2 & 2.92 & 27.38 & 35.80 & 0.12 & 6.19 & 0.07 & 0.27 & 13.37 & 0.02 & 0.91 & 0.11 & 0.04 & 10.04 & 2.77 & 100.00 & Dravite \\
\hline SG11-174B_3 & 2.82 & 25.00 & 35.33 & 0.11 & 6.08 & 0.06 & 0.31 & 15.03 & 0.01 & 2.57 & 0.21 & 0.03 & 10.70 & 1.75 & 100.00 & Dravite \\
\hline SG11-174B_4 & 2.93 & 27.03 & 35.36 & 0.12 & 6.34 & 0.07 & 0.29 & 13.62 & 0.02 & 0.83 & 0.16 & 0.01 & 8.92 & 4.29 & 100.00 & Dravite \\
\hline SG11-174B_5 & 0.02 & 0.01 & 0.07 & 0.00 & 0.78 & 0.02 & 63.73 & 1.97 & 0.54 & 0.01 & 0.01 & 0.00 & 0.00 & 32.84 & 100.00 & Dravite \\
\hline SG11-174B_6 & 3.23 & 25.58 & 35.26 & 0.06 & 6.76 & 0.25 & 0.17 & 14.74 & 0.01 & 0.40 & 0.14 & 0.00 & 12.93 & 0.46 & 100.00 & Dravite \\
\hline SG11-174B_7 & 2.99 & 25.45 & 35.65 & 0.00 & 6.81 & 0.07 & 0.11 & 15.56 & 0.05 & 0.42 & 0.13 & 0.01 & 8.24 & 4.49 & 100.00 & Dravite \\
\hline SG11-174B_8 & 2.94 & 24.39 & 34.96 & 0.00 & 6.07 & 0.10 & 0.26 & 17.00 & 0.03 & 1.27 & 0.18 & 0.05 & 10.14 & 2.60 & 100.00 & Dravite \\
\hline SG11-174B_9 & 3.39 & 26.18 & 35.06 & 0.00 & 6.14 & 0.33 & 0.29 & 14.04 & 0.00 & 1.13 & 0.16 & 0.00 & 14.95 & 0.00 & 101.65 & Dravite \\
\hline
\end{tabular}


Table C3 - Electron microprobe analyses on sulphides from East Bay - Elemental weight \%

Element Weight\%

\begin{tabular}{|c|c|c|c|c|c|c|c|c|c|c|c|c|c|c|}
\hline Sample \# & $\mathbf{S}$ & $\mathbf{F e}$ & $\mathbf{N i}$ & $\mathbf{C u}$ & As & Cd & Ag & $\mathbf{W}$ & $\mathbf{P b}$ & $\mathbf{A u}$ & Te & $\mathrm{Zn}$ & Total & Mineral \\
\hline SG11-175F-1 & 53.13 & 46.47 & 0.23 & 0.00 & 0.32 & 0.00 & 0.02 & 0.00 & 0.13 & 0.00 & 0.00 & 0.01 & 100.31 & Pyrite \\
\hline SG11-175F-2 & 52.51 & 46.58 & 0.23 & 0.00 & 0.13 & 0.00 & 0.00 & 0.00 & 0.16 & 0.07 & 0.00 & 0.00 & 99.67 & Pyrite \\
\hline SG11-175F-3 & 34.63 & 30.60 & 0.00 & 34.61 & 0.04 & 0.05 & 0.01 & 0.00 & 0.08 & 0.00 & 0.00 & 0.00 & 100.00 & Chalcopyrite \\
\hline SG11-175F-4 & 34.90 & 30.63 & 0.00 & 34.47 & 0.05 & 0.04 & 0.01 & 0.00 & 0.13 & 0.04 & 0.00 & 0.02 & 100.27 & Chalcopyrite \\
\hline SG11-175F-5 & 39.20 & 59.38 & 0.31 & 0.00 & 0.07 & 0.00 & 0.03 & 0.00 & 0.11 & 0.00 & 0.00 & 0.00 & 99.10 & Pyrrhotite \\
\hline SG11-175F-6 & 39.48 & 59.37 & 0.36 & 0.00 & 0.07 & 0.02 & 0.01 & 0.00 & 0.10 & 0.00 & 0.00 & 0.00 & 99.41 & Pyrrhotite \\
\hline SG11-175F-7 & 39.39 & 59.29 & 0.36 & 0.01 & 0.06 & 0.00 & 0.01 & 0.00 & 0.14 & 0.06 & 0.00 & 0.02 & 99.33 & Pyrrhotite \\
\hline SG11-175F-8 & 39.33 & 59.62 & 0.36 & 0.00 & 0.08 & 0.01 & 0.03 & 0.00 & 0.15 & 0.00 & 0.00 & 0.00 & 99.58 & Pyrrhotite \\
\hline SG11-175F-9 & 39.31 & 59.70 & 0.37 & 0.00 & 0.04 & 0.00 & 0.02 & 0.00 & 0.12 & 0.00 & 0.00 & 0.01 & 99.57 & Pyrrhotite \\
\hline SG11-175F-10 & 52.34 & 46.74 & 0.09 & 0.00 & 0.04 & 0.04 & 0.01 & 0.00 & 0.17 & 0.02 & 0.00 & 0.01 & 99.45 & Pyrite \\
\hline SG11-175F-11 & 52.91 & 46.57 & 0.26 & 0.00 & 0.09 & 0.01 & 0.03 & 0.00 & 0.11 & 0.00 & 0.00 & 0.00 & 99.98 & Pyrite \\
\hline SG11-175F-12 & 34.35 & 30.48 & 0.00 & 34.36 & 0.06 & 0.00 & 0.01 & 0.00 & 0.06 & 0.08 & 0.00 & 0.01 & 99.42 & Chalcopyrite \\
\hline SG11-175F-13 & 0.00 & 65.68 & 0.00 & 0.01 & 0.12 & 0.00 & 0.02 & 0.00 & 0.04 & 0.00 & 0.00 & 0.01 & 65.88 & N/A \\
\hline SG11-175F-14 & 39.25 & 59.73 & 0.36 & 0.01 & 0.04 & 0.03 & 0.01 & 0.00 & 0.10 & 0.00 & 0.00 & 0.02 & 99.56 & Pyrrhotite \\
\hline MB891-05-1 & 39.04 & 60.67 & 0.15 & 0.05 & 0.06 & 0.05 & 0.00 & 0.00 & 0.10 & 0.00 & 0.00 & 0.00 & 100.13 & Pyrrhotite \\
\hline MB891-05-2 & 34.61 & 30.74 & 0.01 & 34.50 & 0.03 & 0.02 & 0.00 & 0.00 & 0.13 & 0.00 & 0.00 & 0.01 & 100.06 & Chalcopyrite \\
\hline MB891-05-3 & 53.42 & 46.88 & 0.01 & 0.00 & 0.07 & 0.03 & 0.02 & 0.00 & 0.13 & 0.07 & 0.00 & 0.00 & 100.64 & Pyrite \\
\hline MB891-05-4 & 53.19 & 45.96 & 0.01 & 0.03 & 0.14 & 0.04 & 0.02 & 0.00 & 0.11 & 0.04 & 0.00 & 0.00 & 99.52 & Pyrite \\
\hline MB891-05-5 & 34.65 & 30.29 & 0.00 & 34.42 & 0.06 & 0.03 & 0.00 & 0.00 & 0.12 & 0.00 & 0.00 & 0.00 & 99.56 & Chalcopyrite \\
\hline MB891-05-6 & 38.91 & 60.52 & 0.26 & 0.02 & 0.05 & 0.03 & 0.02 & 0.00 & 0.12 & 0.06 & 0.00 & 0.00 & 99.99 & Pyrrhotite \\
\hline MB891-05-7 & 38.36 & 60.43 & 0.25 & 0.00 & 0.06 & 0.01 & 0.03 & 0.00 & 0.09 & 0.04 & 0.00 & 0.01 & 99.29 & Pyrrhotite \\
\hline MB891-05-8 & 38.57 & 60.36 & 0.25 & 0.00 & 0.05 & 0.00 & 0.03 & 0.00 & 0.13 & 0.00 & 0.00 & 0.00 & 99.38 & Pyrrhotite \\
\hline
\end{tabular}


Table C3 (Cont)

\begin{tabular}{|c|c|c|c|c|c|c|c|c|c|c|c|c|c|c|}
\hline Sample \# & $\mathbf{S}$ & $\mathbf{F e}$ & $\mathrm{Ni}$ & $\mathrm{Cu}$ & As & Cd & $\mathbf{A g}$ & $\mathbf{W}$ & $\mathbf{P b}$ & $\mathbf{A u}$ & Te & Zn & Total & Mineral \\
\hline MB891-05-9 & 33.75 & 30.51 & 0.02 & 34.12 & 0.02 & 0.01 & 0.01 & 0.00 & 0.14 & 0.00 & 0.00 & 0.00 & 98.57 & Chalcopyrite \\
\hline MB891-05-10 & 38.37 & 60.42 & 0.12 & 0.15 & 0.08 & 0.01 & 0.01 & 0.00 & 0.12 & 0.05 & 0.00 & 0.01 & 99.33 & Pyrrhotite \\
\hline MB891-05-11 & 34.23 & 31.04 & 0.02 & 33.91 & 0.03 & 0.08 & 0.01 & 0.00 & 0.14 & 0.00 & 0.00 & 0.03 & 99.49 & Chalcopyrite \\
\hline MB891-05-12 & 38.68 & 60.39 & 0.13 & 0.00 & 0.05 & 0.02 & 0.03 & 0.00 & 0.11 & 0.04 & 0.00 & 0.01 & 99.46 & Pyrrhotite \\
\hline MB891-05-13 & 39.20 & 59.86 & 0.05 & 0.01 & 0.02 & 0.04 & 0.02 & 0.00 & 0.05 & 0.00 & 0.00 & 0.00 & 99.25 & Pyrrhotite \\
\hline EB10040-03-1 & 34.22 & 29.91 & 0.01 & 34.55 & 0.04 & 0.00 & 0.00 & 0.00 & 0.09 & 0.00 & 0.00 & 0.03 & 98.86 & Chalcopyrite \\
\hline EB10040-03-2 & 38.48 & 59.75 & 0.54 & 0.00 & 0.06 & 0.18 & 0.01 & 0.00 & 0.11 & 0.05 & 0.00 & 0.02 & 99.20 & Pyrrhotite \\
\hline EB10040-03-3 & 39.02 & 59.94 & 0.34 & 0.03 & 0.11 & 0.07 & 0.01 & 0.00 & 0.05 & 0.03 & 0.00 & 0.02 & 99.62 & Pyrrhotite \\
\hline EB10040-03-4 & 52.78 & 46.83 & 0.01 & 0.00 & 0.02 & 0.06 & 0.00 & 0.00 & 0.12 & 0.06 & 0.00 & 0.01 & 99.90 & Pyrite \\
\hline EB10040-03-5 & 52.02 & 46.95 & 0.00 & 0.00 & 0.05 & 0.02 & 0.00 & 0.00 & 0.09 & 0.01 & 0.00 & 0.00 & 99.14 & Pyrite \\
\hline EB10040-03-6 & 51.54 & 44.63 & 0.09 & 0.00 & 2.09 & 0.03 & 0.00 & 0.00 & 0.22 & 0.00 & 0.00 & 0.00 & 98.61 & Arsenopyrite \\
\hline EB10040-03-7 & 50.83 & 44.15 & 0.12 & 0.02 & 2.50 & 0.06 & 0.03 & 0.00 & 0.09 & 0.00 & 0.00 & 0.00 & 97.79 & Arsenopyrite \\
\hline EB10040-03-8 & 33.61 & 6.37 & 0.00 & 0.00 & 0.04 & 0.67 & 0.00 & 0.00 & 0.06 & 0.00 & 0.00 & 60.25 & 101.00 & Sphalerite \\
\hline EB10040-03-9 & 36.75 & 40.81 & 0.00 & 29.78 & 0.05 & 0.04 & 0.00 & 0.00 & 0.06 & 0.00 & 0.00 & 0.62 & 108.09 & Chalcopyrite \\
\hline EB10040-03-10 & 38.88 & 60.19 & 0.45 & 0.01 & 0.04 & 0.00 & 0.03 & 0.00 & 0.10 & 0.05 & 0.00 & 0.05 & 99.80 & Pyrrhotite \\
\hline EB10040-03-11 & 38.73 & 60.42 & 0.49 & 0.02 & 0.05 & 0.00 & 0.01 & 0.00 & 0.14 & 0.03 & 0.00 & 0.03 & 99.91 & Pyrrhotite \\
\hline EB10040-03-12 & 33.54 & 6.22 & 0.00 & 0.01 & 0.01 & 0.61 & 0.01 & 0.02 & 0.10 & 0.00 & 0.00 & 59.66 & 100.17 & Sphalerite \\
\hline EB10040-03-13 & 33.31 & 6.27 & 0.00 & 0.00 & 0.00 & 0.67 & 0.01 & 0.01 & 0.14 & 0.00 & 0.00 & 59.05 & 99.47 & Sphalerite \\
\hline EB10040-03-14 & 34.18 & 30.18 & 0.00 & 34.38 & 0.00 & 0.00 & 0.01 & 0.01 & 0.04 & 0.02 & 0.01 & 0.07 & 98.90 & Chalcopyrite \\
\hline EB10040-03-15 & 52.57 & 46.10 & 0.03 & 0.01 & 0.11 & 0.05 & 0.00 & 0.00 & 0.18 & 0.00 & 0.00 & 0.01 & 99.05 & Pyrite \\
\hline EB10040-03-16 & 32.43 & 30.37 & 34.82 & 0.00 & 0.03 & 0.07 & 0.01 & 0.00 & 0.08 & 0.05 & 0.00 & 0.00 & 97.84 & Pentlandite \\
\hline EB10040-03-17 & 39.42 & 59.62 & 0.22 & 0.00 & 0.04 & 0.00 & 0.00 & 0.00 & 0.15 & 0.06 & 0.00 & 0.01 & 99.52 & Pyrrhotite \\
\hline EB10040-03-18 & 38.54 & 60.25 & 0.54 & 0.01 & 0.04 & 0.01 & 0.02 & 0.00 & 0.13 & 0.05 & 0.00 & 0.02 & 99.60 & Pyrrhotite \\
\hline EB10040-03-19 & 33.21 & 31.02 & 34.44 & 0.00 & 0.03 & 0.02 & 0.02 & 0.00 & 0.12 & 0.00 & 0.00 & 0.01 & 98.87 & Pentlandite \\
\hline
\end{tabular}


Table C3 (Cont)

\begin{tabular}{|c|c|c|c|c|c|c|c|c|c|c|c|c|c|c|}
\hline Sample \# & $\mathbf{S}$ & $\mathbf{F e}$ & $\mathbf{N i}$ & $\mathbf{C u}$ & As & Cd & Ag & $\mathbf{W}$ & $\mathbf{P b}$ & $\mathbf{A u}$ & Te & $\mathbf{Z n}$ & Total & Mineral \\
\hline EB10040-03-20 & 38.89 & 59.74 & 0.18 & 0.01 & 0.04 & 0.01 & 0.00 & 0.00 & 0.14 & 0.04 & 0.00 & 0.00 & 99.06 & Pyrrhotite \\
\hline EB10040-03-21 & 33.36 & 6.40 & 0.01 & 0.01 & 0.05 & 0.68 & 0.01 & 0.02 & 0.11 & 0.01 & 0.00 & 59.81 & 100.46 & Sphalerite \\
\hline EB10040-03-22 & 35.39 & 36.06 & 0.04 & 26.90 & 0.10 & 0.06 & 0.01 & 0.00 & 0.08 & 0.00 & 0.00 & 0.37 & 99.00 & Chalcopyrite \\
\hline EB10040-03-23 & 39.53 & 59.75 & 0.25 & 0.00 & 0.05 & 0.01 & 0.04 & 0.00 & 0.10 & 0.07 & 0.00 & 0.02 & 99.82 & Pyrrhotite \\
\hline EB10040-03-24 & 38.93 & 60.38 & 0.49 & 0.01 & 0.06 & 0.04 & 0.00 & 0.00 & 0.12 & 0.02 & 0.00 & 0.01 & 100.05 & Pyrrhotite \\
\hline EB10040-03-25 & 53.27 & 46.15 & 0.01 & 0.00 & 0.15 & 0.06 & 0.01 & 0.00 & 0.16 & 0.08 & 0.00 & 0.00 & 99.88 & Pyrite \\
\hline EB10040-03-26 & 53.07 & 45.99 & 0.02 & 0.00 & 0.06 & 0.05 & 0.00 & 0.00 & 0.17 & 0.01 & 0.00 & 0.01 & 99.38 & Pyrite \\
\hline EB10040-03-27 & 52.12 & 45.86 & 0.00 & 0.02 & 0.26 & 0.07 & 0.02 & 0.00 & 0.21 & 0.00 & 0.00 & 0.00 & 98.56 & Pyrite \\
\hline EB10040-03-28 & 52.41 & 45.57 & 0.04 & 0.00 & 0.51 & 0.32 & 0.02 & 0.00 & 0.17 & 0.00 & 0.00 & 0.01 & 99.03 & Pyrite \\
\hline EB10040-03-29 & 52.53 & 46.38 & 0.01 & 0.00 & 0.22 & 0.02 & 0.01 & 0.00 & 0.10 & 0.03 & 0.00 & 0.02 & 99.32 & Pyrite \\
\hline EB10040-03-30 & 33.25 & 6.13 & 0.00 & 0.01 & 0.07 & 0.58 & 0.00 & 0.00 & 0.07 & 0.01 & 0.00 & 59.70 & 99.83 & Sphalerite \\
\hline ABU38-02-1 & 34.53 & 30.52 & 0.00 & 34.40 & 0.03 & 0.07 & 0.01 & 0.00 & 0.09 & 0.00 & 0.00 & 0.00 & 99.65 & Chalcopyrite \\
\hline ABU38-02-2 & 39.25 & 60.29 & 0.00 & 0.00 & 0.04 & 0.00 & 0.01 & 0.00 & 0.20 & 0.08 & 0.00 & 0.00 & 99.88 & Pyrrhotite \\
\hline ABU38-02-3 & 39.82 & 60.29 & 0.00 & 0.02 & 0.09 & 0.00 & 0.03 & 0.00 & 0.10 & 0.00 & 0.00 & 0.00 & 100.35 & Pyrrhotite \\
\hline ABU38-02-4 & 40.21 & 60.06 & 0.01 & 0.00 & 0.04 & 0.02 & 0.03 & 0.00 & 0.10 & 0.07 & 0.00 & 0.00 & 100.53 & Pyrrhotite \\
\hline ABU38-02-5 & 39.49 & 60.13 & 0.03 & 0.00 & 0.11 & 0.00 & 0.03 & 0.00 & 0.09 & 0.03 & 0.00 & 0.02 & 99.93 & Pyrrhotite \\
\hline ABU38-02-6 & 39.56 & 60.38 & 0.01 & 0.00 & 0.03 & 0.00 & 0.01 & 0.00 & 0.07 & 0.02 & 0.00 & 0.02 & 100.11 & Pyrrhotite \\
\hline ABU38-02-7 & 39.13 & 60.21 & 0.01 & 0.00 & 0.04 & 0.00 & 0.00 & 0.00 & 0.12 & 0.01 & 0.00 & 0.00 & 99.53 & Pyrrhotite \\
\hline MB894-01-1 & 53.26 & 46.59 & 0.01 & 0.01 & 0.15 & 0.00 & 0.05 & 0.00 & 0.17 & 0.04 & 0.00 & 0.00 & 100.27 & Pyrite \\
\hline MB894-01-2 & 51.73 & 46.14 & 0.03 & 0.00 & 0.18 & 0.01 & 0.00 & 0.00 & 0.15 & 0.05 & 0.00 & 0.00 & 98.29 & Pyrite \\
\hline MB894-01-3 & 52.43 & 46.84 & 0.04 & 0.02 & 0.49 & 0.00 & 0.02 & 0.00 & 0.11 & 0.00 & 0.00 & 0.00 & 99.94 & Pyrite \\
\hline MB894-01-4 & 50.35 & 44.01 & 0.03 & 1.86 & 0.50 & 0.00 & 0.03 & 0.00 & 0.16 & 0.00 & 0.00 & 0.24 & 97.19 & Pyrite \\
\hline MB894-01-5 & 52.76 & 46.99 & 0.01 & 0.00 & 0.06 & 0.02 & 0.01 & 0.00 & 0.15 & 0.00 & 0.00 & 0.00 & 99.99 & Pyrite \\
\hline
\end{tabular}




\section{Table C3 (Cont)}

\begin{tabular}{|c|c|c|c|c|c|c|c|c|c|c|c|c|c|c|}
\hline Sample \# & $\mathbf{S}$ & $\mathbf{F e}$ & $\mathrm{Ni}$ & $\mathrm{Cu}$ & As & Cd & Ag & $\mathbf{W}$ & $\mathbf{P b}$ & $\mathbf{A u}$ & Te & Zn & Total & Mineral \\
\hline MB894-01-6 & 52.89 & 46.68 & 0.06 & 0.01 & 0.25 & 0.09 & 0.04 & 0.00 & 0.13 & 0.00 & 0.00 & 0.01 & 100.18 & Pyrite \\
\hline MB894-01-7 & 27.20 & 4.40 & 0.00 & 38.26 & 0.85 & 0.25 & 0.17 & 0.00 & 0.05 & 0.09 & 0.00 & 5.59 & 76.86 & Chalcopyrite \\
\hline MB894-01-8 & 53.04 & 46.98 & 0.04 & 0.00 & 0.13 & 0.03 & 0.04 & 0.00 & 0.16 & 0.00 & 0.00 & 0.02 & 100.43 & Pyrite \\
\hline MB894-01-9 & 53.03 & 46.77 & 0.02 & 0.02 & 0.22 & 0.09 & 0.01 & 0.00 & 0.13 & 0.03 & 0.00 & 0.00 & 100.33 & Pyrite \\
\hline MB894-01-10 & 34.74 & 29.64 & 0.00 & 34.56 & 0.06 & 0.00 & 0.00 & 0.00 & 0.15 & 0.00 & 0.00 & 0.00 & 99.15 & Chalcopyrite \\
\hline MB894-01-11 & 34.73 & 29.94 & 0.00 & 34.71 & 0.04 & 0.08 & 0.01 & 0.00 & 0.06 & 0.00 & 0.00 & 0.00 & 99.57 & Chalcopyrite \\
\hline MB894-01-12 & 53.07 & 47.04 & 0.00 & 0.02 & 0.02 & 0.05 & 0.00 & 0.00 & 0.12 & 0.00 & 0.00 & 0.00 & 100.33 & Pyrite \\
\hline
\end{tabular}


Appendix D

Fluid Inclusion Analysis 


\section{Tuckers Knob}

\begin{tabular}{|c|c|c|c|c|c|c|c|c|c|}
\hline Sample & $\begin{array}{l}\text { Occurrence of } \\
\text { fluid inclusions }\end{array}$ & $\begin{array}{l}\text { Primary/ } \\
\text { Secondary }\end{array}$ & $\begin{array}{l}\text { Size } \\
(\mu \mathrm{m})\end{array}$ & $\begin{array}{l}\mathrm{T}_{\mathrm{m}-\mathrm{CO} 2} \\
\left({ }^{\circ} \mathrm{C}\right)\end{array}$ & $\begin{array}{c}\mathbf{T}_{\mathrm{m}-\mathrm{H} 2 \mathrm{O}} \\
\left({ }^{\circ} \mathrm{C}\right)\end{array}$ & $\begin{array}{l}\mathrm{T}_{\mathrm{h}-\mathrm{CO} 2} \\
\left({ }^{\circ} \mathrm{C}\right)\end{array}$ & $\begin{array}{l}\mathrm{T}_{\mathrm{h}-\mathrm{H} 2 \mathrm{O}} \\
\left({ }^{\circ} \mathrm{C}\right)\end{array}$ & $\begin{array}{l}\mathrm{Wt} \% \\
\mathrm{NaCl}- \\
\mathrm{MgCl}_{2}\end{array}$ & Vol \% \\
\hline SG11-171D & Angular/ Isolated & Primary & $\sim 20$ & -58.4 & & 8.9 & & & $\begin{array}{l}\sim 80 \% \text { Vapor } \\
\sim 20 \% \text { Liquid }\end{array}$ \\
\hline SG11-171D & $\begin{array}{c}\text { Subrounded/ } \\
\text { Scattered Cluster }\end{array}$ & Primary & $\sim 8$ & -57.9 & & 13.5 & & & $\begin{array}{l}\sim 65 \% \mathrm{~V} \\
\sim 35 \% \mathrm{~L}\end{array}$ \\
\hline SG11-171D & $\begin{array}{l}\text { Oval/ Edge of } \\
\text { Cluster }\end{array}$ & Primary & $\sim 22$ & -59.2 & & 9.1 & & & $\begin{array}{l}\sim 20 \% \mathrm{~V} \\
\sim 80 \% \mathrm{~L}\end{array}$ \\
\hline SG11-171D & Elongate/ Cluster & Primary & $\sim 12$ & -58.1 & & 9.0 & & & $\begin{array}{l}\sim 40 \% \mathrm{~V} \\
\sim 60 \% \mathrm{~L}\end{array}$ \\
\hline SG11-171D & Angular/ Cluster & Primary & $\sim 25$ & -58.9 & & 15.6 & & & $\begin{array}{l}\sim 40 \% \mathrm{~V} \\
\sim 60 \% \mathrm{~L}\end{array}$ \\
\hline SG11-171D & $\begin{array}{l}\text { Oval-elongate/ } \\
\text { cluster }\end{array}$ & Primary & $\sim 10$ & -58.9 & & 12.9 & & & $\begin{array}{l}\sim 50 \% \mathrm{~V} \\
\sim 50 \% \mathrm{~L}\end{array}$ \\
\hline SG11-171D & $\begin{array}{l}\text { Oval/ Scattered } \\
\text { Cluster }\end{array}$ & Primary & $\sim 8$ & -58.7 & & 15.0 & & & $\begin{array}{l}\sim 30 \% \mathrm{~V} \\
\sim 70 \% \mathrm{~L}\end{array}$ \\
\hline SG11-171D & Oval/ Cluster & Primary & $\sim 12$ & -58.6 & & 14.8 & & & $\begin{array}{l}\sim 40 \% \mathrm{~V} \\
\sim 60 \% \mathrm{~L}\end{array}$ \\
\hline SG11-171D & $\begin{array}{l}\text { Subrounded/ } \\
\text { Cluster }\end{array}$ & Primary & $\sim 15$ & -58.6 & & 17.7 & & & $\begin{array}{l}\sim 30 \% \mathrm{~V} \\
\sim 70 \% \mathrm{~L}\end{array}$ \\
\hline SG11-171D & $\begin{array}{c}\text { Rounded/ Scattered } \\
\text { Cluster }\end{array}$ & Primary & $\sim 30$ & -59.0 & & 14.6 & & & $\begin{array}{l}\sim 35 \% \mathrm{~V} \\
\sim 65 \% \mathrm{~L}\end{array}$ \\
\hline SG11-171D & Elongate/ Cluster & Primary & $\sim 20$ & -59.7 & & 18.0 & & & $\begin{array}{l}\sim 45 \% \mathrm{~V} \\
\sim 55 \% \mathrm{~L}\end{array}$ \\
\hline SG11-171D & Elongate/ Cluster & Primary & $\sim 18$ & -58.2 & & 19.1 & & & $\begin{array}{l}\sim 25 \% \mathrm{~V} \\
\sim 75 \% \mathrm{~L}\end{array}$ \\
\hline SG11-171D & Elongate/ Cluster & Primary & $\sim 15$ & -58.5 & & 17.4 & & & $\begin{array}{l}\sim 30 \% \mathrm{~V} \\
\sim 70 \% \mathrm{~L}\end{array}$ \\
\hline SG11-171D & Oval/ Cluster & Primary & $\sim 15$ & -58.7 & & 16.6 & & & $\begin{array}{l}\sim 30 \% \mathrm{~V} \\
\sim 70 \% \mathrm{~L}\end{array}$ \\
\hline SG11-171D & Oval/ Cluster & Primary & $\sim 15$ & -59.8 & & 10.0 & & & $\begin{array}{l}\sim 25 \% \mathrm{~V} \\
\sim 75 \% \mathrm{~L}\end{array}$ \\
\hline SG11-171D & $\begin{array}{c}\text { Elongate/ Scattered } \\
\text { Cluster }\end{array}$ & Primary & $\sim 40$ & -58.6 & & 9.7 & & & $\begin{array}{l}\sim 20 \% \mathrm{~V} \\
\sim 80 \% \mathrm{~L}\end{array}$ \\
\hline SG11-171D & Angular/ Cluster & Primary & $\sim 15$ & -58.7 & & 16.7 & & & $\begin{array}{l}\sim 30 \% \mathrm{~V} \\
\sim 70 \% \mathrm{~L}\end{array}$ \\
\hline SG11-171D & Elongate/ Trail & Secondary & $\sim 12$ & & -1.0 & & 205.4 & 1.0 & $\begin{array}{l}\sim 15 \% \mathrm{~V} \\
\sim 85 \% \mathrm{~L}\end{array}$ \\
\hline SG11-171D & Elongate/ Trail & Secondary & $\sim 15$ & & -18.6 & & 222.1 & 21.4 & $\begin{array}{l}\sim 20 \% \mathrm{~V} \\
\sim 80 \% \mathrm{~L}\end{array}$ \\
\hline SG11-171D & $\begin{array}{l}\text { Subrounded/ } \\
\text { Isolated }\end{array}$ & Primary & $\sim 10$ & -59.1 & & 14.9 & & & $\begin{array}{l}\sim 30 \% \mathrm{~V} \\
\sim 70 \% \mathrm{~L}\end{array}$ \\
\hline SG11-171D & & Secondary & & & & & & & $\begin{array}{l}\sim 15 \% \mathrm{~V} \\
\sim 85 \% \mathrm{~L}\end{array}$ \\
\hline SG11-171D & Oval/ Isolated & Primary & $\sim 15$ & -57.8 & & 17.2 & & & $\begin{array}{l}\sim 30 \% \mathrm{~V} \\
\sim 70 \% \mathrm{~L}\end{array}$ \\
\hline SG11-171D & Angular/ Cluster & Primary & $\sim 20$ & -58.5 & & 14.5 & & & $\begin{array}{l}\sim 60 \% \mathrm{~V} \\
\sim 40 \% \mathrm{~L}\end{array}$ \\
\hline SG11-171D & Elongate/ Trail & Secondary & $\sim 15$ & & -18.8 & & 213.7 & 21.6 & $\begin{array}{l}\sim 10 \% \mathrm{~V} \\
\sim 90 \% \mathrm{~L}\end{array}$ \\
\hline SG11-171D & Oval/ Cluster & Secondary & $\sim 25$ & & -20.8 & & 212.0 & 23.0 & $\begin{array}{l}\sim 20 \% \mathrm{~V} \\
\sim 80 \% \mathrm{~L}\end{array}$ \\
\hline
\end{tabular}




\begin{tabular}{|c|c|c|c|c|c|c|c|c|c|}
\hline Sample & $\begin{array}{l}\text { Occurrence of } \\
\text { fluid inclusions }\end{array}$ & $\begin{array}{l}\text { Primary / } \\
\text { Secondary }\end{array}$ & $\begin{array}{l}\text { Size } \\
(\mu \mathrm{m})\end{array}$ & $\begin{array}{l}\mathrm{T}_{\mathrm{m}-\mathrm{CO} 2} \\
\left({ }^{\circ} \mathrm{C}\right)\end{array}$ & $\begin{array}{c}\mathrm{T}_{\mathrm{m}-\mathrm{H} 2 \mathrm{O}} \\
\left({ }^{\circ} \mathrm{C}\right)\end{array}$ & $\begin{array}{l}\mathrm{T}_{\mathrm{h}-\mathrm{CO} 2} \\
\left({ }^{\circ} \mathrm{C}\right)\end{array}$ & $\begin{array}{l}\mathrm{T}_{\mathrm{h}-\mathrm{H} 2 \mathrm{O}} \\
\left({ }^{\circ} \mathrm{C}\right)\end{array}$ & $\begin{array}{l}\text { Wt \% } \\
\text { NaCl }\end{array}$ & Vol \% \\
\hline SG11-171D & Oval/ Cluster & Secondary & $\sim 12$ & & -23.3 & & 202.4 & 24.6 & $\begin{array}{l}\sim 15 \% \mathrm{~V} \\
\sim 85 \% \mathrm{~L}\end{array}$ \\
\hline SG11-171D & Oval/ Cluster & Primary & $\sim 15$ & -58.2 & & 15.7 & & & $\begin{array}{l}\sim 20 \% \mathrm{~V} \\
\sim 80 \% \mathrm{~L}\end{array}$ \\
\hline SG11-171D & Elongate/ Cluster & Primary & $\sim 10$ & -59.1 & & 15.1 & & & $\begin{array}{l}\sim 25 \% \mathrm{~V} \\
\sim 75 \% \mathrm{~L}\end{array}$ \\
\hline SG11-171D & Angular/ Cluster & Primary & $\sim 25$ & & -19.5 & & 216.9 & 22.1 & $\begin{array}{l}\sim 10 \% \mathrm{~V} \\
\sim 90 \% \mathrm{~L}\end{array}$ \\
\hline SG11-171D & Oval/ Isolated & Primary & $\sim 15$ & -58.8 & & 16.2 & & & $\begin{array}{l}\sim 20 \% \mathrm{~V} \\
\sim 80 \% \mathrm{~L}\end{array}$ \\
\hline SG11-171D & Oval/ Isolated & Primary & $\sim 15$ & -58.5 & & 9.8 & & & $\begin{array}{l}\sim 25 \% \mathrm{~V} \\
\sim 75 \% \mathrm{~L}\end{array}$ \\
\hline SG11-171D & $\begin{array}{c}\text { Subrounded/ } \\
\text { Scattered Cluster }\end{array}$ & Primary & $\sim 20$ & -57.0 & -10.8 & 9.9 & $278.9^{\mathrm{D}}$ & 13.8 & $\begin{array}{l}\sim 35 \% \mathrm{~V} \\
\sim 65 \% \mathrm{~L}\end{array}$ \\
\hline SG11-171D & $\begin{array}{l}\text { Oval/ Scattered } \\
\text { Cluster }\end{array}$ & Primary & $\sim 15$ & -57.6 & -7.4 & 10.0 & 267.2 & 15.1 & $\begin{array}{l}\sim 25 \% \mathrm{~V} \\
\sim 75 \% \mathrm{~L}\end{array}$ \\
\hline SG11-171D & $\begin{array}{c}\text { Oval/ Scattered } \\
\text { Cluster }\end{array}$ & Primary & $\sim 12$ & -58.2 & -8.6 & 9.9 & 270.8 & 12.6 & $\begin{array}{l}\sim 20 \% \mathrm{~V} \\
\sim 80 \% \mathrm{~L}\end{array}$ \\
\hline SG11-171D & $\begin{array}{c}\text { Subangular/ } \\
\text { Scattered Cluster }\end{array}$ & Primary & $\sim 35$ & -58.2 & -9.8 & 7.8 & 288.3 & 13.5 & $\begin{array}{l}\sim 35 \% \mathrm{~V} \\
\sim 65 \% \mathrm{~L}\end{array}$ \\
\hline SG11-171D & $\begin{array}{l}\text { Subangular/ } \\
\text { Cluster }\end{array}$ & Primary & $\sim 25$ & -57.9 & & 8.8 & & & $\begin{array}{l}\sim 40 \% \mathrm{~V} \\
\sim 60 \% \mathrm{~L}\end{array}$ \\
\hline
\end{tabular}

\section{CHEVRON ZONE (Mineralized)}

\begin{tabular}{|c|c|c|c|c|c|c|c|c|c|}
\hline Sample & $\begin{array}{l}\text { Occurrence of } \\
\text { fluid inclusions }\end{array}$ & $\begin{array}{l}\text { Primary / } \\
\text { Secondary }\end{array}$ & $\begin{array}{l}\text { Size } \\
(\mu \mathbf{m})\end{array}$ & $\begin{array}{l}\mathrm{T}_{\mathrm{m}-\mathrm{CO} 2} \\
\left({ }^{\circ} \mathrm{C}\right)\end{array}$ & $\begin{array}{l}\mathbf{T}_{\mathrm{m}-\mathrm{H} 2 \mathrm{O}} \\
\left({ }^{\circ} \mathbf{C}\right)\end{array}$ & $\begin{array}{l}\mathrm{T}_{\mathrm{h}-\mathrm{CO} 2} \\
\left({ }^{\circ} \mathrm{C}\right)\end{array}$ & $\begin{array}{l}\mathrm{T}_{\mathrm{h}-\mathrm{H} 2 \mathrm{O}} \\
\left({ }^{\circ} \mathrm{C}\right)\end{array}$ & $\begin{array}{l}\text { Wt \% } \\
\text { NaCl }\end{array}$ & Vol \% \\
\hline EB9017-01 & $\begin{array}{c}\text { Angular/ Scattered } \\
\text { Cluster }\end{array}$ & Primary & $\sim 20$ & -56.9 & -11.6 & 19.7 & $229.8 \mathrm{D}$ & 15.7 & $\begin{array}{l}\sim 15 \% \mathrm{~V} \\
\sim 85 \% \mathrm{~L}\end{array}$ \\
\hline EB9017-01 & $\begin{array}{c}\text { Square/ Scattered } \\
\text { Cluster }\end{array}$ & Primary & $\sim 25$ & -56.6 & & 1.2 & $212.4 \mathrm{D}$ & & $\begin{array}{l}\sim 20 \% \mathrm{~V} \\
\sim 80 \% \mathrm{~L}\end{array}$ \\
\hline EB9017-01 & $\begin{array}{c}\text { Angular/ Scattered } \\
\text { Cluster }\end{array}$ & Primary & $\sim 25$ & -56.7 & -18.6 & 6.4 & $276.7 \mathrm{D}$ & 21.5 & $\begin{array}{l}\sim 20 \% \mathrm{~V} \\
\sim 80 \% \mathrm{~L}\end{array}$ \\
\hline EB9017-01 & $\begin{array}{l}\text { Angular-elongate/ } \\
\text { Scattered Cluster }\end{array}$ & Primary & $\sim 30$ & -56.7 & -19.6 & 5.6 & $196.2 \mathrm{D}$ & 22.1 & $\begin{array}{l}\sim 20 \% \mathrm{~V} \\
\sim 80 \% \mathrm{~L}\end{array}$ \\
\hline EB9017-01 & Oval/ Cluster & Primary & $\sim 20$ & -56.8 & & 19.2 & & & $\begin{array}{l}\sim 40 \% \mathrm{~V} \\
\sim 60 \% \mathrm{~L}\end{array}$ \\
\hline EB9017-01 & $\begin{array}{l}\text { Subrounded/ } \\
\text { Cluster }\end{array}$ & Primary & $\sim 10$ & -56.9 & & 12.0 & & & $\begin{array}{l}\sim 30 \% \mathrm{~V} \\
\sim 70 \% \mathrm{~L}\end{array}$ \\
\hline EB9017-01 & $\begin{array}{l}\text { Subrounded/ } \\
\text { Cluster }\end{array}$ & Primary & $\sim 15$ & -56.3 & & 11.6 & & & $\begin{array}{l}\sim 20 \% \mathrm{~V} \\
\sim 80 \% \mathrm{~L}\end{array}$ \\
\hline EB9017-01 & $\begin{array}{l}\text { Oval/ Scattered } \\
\text { Cluster }\end{array}$ & Primary & $\sim 20$ & -56.2 & -19.4 & 17.7 & 230.4 & 22.2 & $\begin{array}{l}\sim 15 \% \mathrm{~V} \\
\sim 85 \% \mathrm{~L}\end{array}$ \\
\hline EB9017-01 & $\begin{array}{c}\text { Oval/ Scattered } \\
\text { Cluster }\end{array}$ & Primary & $\sim 20$ & -56.3 & -19.0 & 20.5 & $264.4 \mathrm{D}$ & 22.0 & $\begin{array}{l}\sim 15 \% \mathrm{~V} \\
\sim 85 \% \mathrm{~L}\end{array}$ \\
\hline EB9017-01 & $\begin{array}{c}\text { Oval/ Scattered } \\
\text { Cluster }\end{array}$ & Primary & $\sim 15$ & -57.0 & -13.4 & 4.3 & 255.7 & 17.1 & $\begin{array}{l}\sim 20 \% \mathrm{~V} \\
\sim 80 \% \mathrm{~L}\end{array}$ \\
\hline EB9017-01 & $\begin{array}{l}\text { Subrounded/ } \\
\text { Isolated }\end{array}$ & Primary & $\sim 20$ & -56.4 & -17.6 & 7.6 & $291.8 \mathrm{D}$ & 21.0 & $\begin{array}{l}\sim 30 \% \mathrm{~V} \\
\sim 70 \% \mathrm{~L}\end{array}$ \\
\hline
\end{tabular}




\begin{tabular}{|c|c|c|c|c|c|c|c|c|c|}
\hline EB9017-01 & Elongate/ Trail & Secondary & $\sim 12$ & & -23.2 & & 182.8 & 24.7 & $\begin{array}{l}\sim 20 \% \mathrm{~V} \\
\sim 80 \% \mathrm{~L}\end{array}$ \\
\hline EB9017-01 & Elongate/ Trail & Secondary & $\sim 10$ & & -22.6 & & 192.4 & 24.1 & $\begin{array}{l}\sim 10 \% \mathrm{~V} \\
\sim 90 \% \mathrm{~L}\end{array}$ \\
\hline EB9017-01 & Oval/ Trail & Secondary & $\sim 10$ & & -24.2 & & 155.8 & 25.5 & $\begin{array}{l}\sim 15 \% \mathrm{~V} \\
\sim 85 \% \mathrm{~L}\end{array}$ \\
\hline EB9017-01 & $\begin{array}{l}\text { Very Elongated/ } \\
\text { Trail }\end{array}$ & Secondary & $\begin{array}{c}\sim 5 \times 2 \\
5\end{array}$ & & -21.3 & & 172.6 & 23.1 & $\begin{array}{l}\sim 10 \% \mathrm{~V} \\
\sim 90 \% \mathrm{~L}\end{array}$ \\
\hline EB9017-01 & Oval/ Trail & Secondary & $\sim 12$ & -56.6 & -22.4 & 7.9 & 197.6 & 24.0 & $\begin{array}{l}\sim 30 \% \mathrm{~V} \\
\sim 70 \% \mathrm{~L}\end{array}$ \\
\hline EB9017-01 & Oval/ Cluster & Primary & $\sim 15$ & & -6.0 & & 334.1 & 9.2 & $\begin{array}{l}\sim 20 \% \mathrm{~V} \\
\sim 80 \% \mathrm{~L}\end{array}$ \\
\hline EB9017-01 & $\begin{array}{l}\text { Oval-Elongate/ } \\
\text { Cluster }\end{array}$ & Primary & $\sim 8$ & & -8.2 & & 364.7 & 12.2 & $\begin{array}{l}\sim 35 \% \mathrm{~V} \\
\sim 65 \% \mathrm{~L}\end{array}$ \\
\hline EB9017-01 & Oval/ Isolated & Primary & $\sim 20$ & -57.4 & & 5.1 & & & $\sim 20 \% \mathrm{CO} 2$ \\
\hline EB9017-01 & $\begin{array}{c}\text { Oval/ Scattered } \\
\text { Cluster }\end{array}$ & Primary & $\sim 15$ & -57.6 & & 6.5 & & & $\sim 35 \% \mathrm{CO} 2$ \\
\hline EB9017-01 & $\begin{array}{l}\text { Subrounded/ } \\
\text { Isolated }\end{array}$ & Primary & $\sim 18$ & -56.1 & -11.1 & 9.1 & $261.7 \mathrm{D}$ & 14.3 & $\begin{array}{l}\sim 55 \% \mathrm{H} 2 \mathrm{O} \\
\sim 30 \% \mathrm{CO} 2\end{array}$ \\
\hline EB9017-01 & $\begin{array}{c}\text { Oval/ Scattered } \\
\text { Cluster }\end{array}$ & Primary & $\sim 15$ & -56.1 & -12.6 & 11.2 & 278.3 & 16.2 & $\begin{array}{l}\sim 35 \% \mathrm{H} 2 \mathrm{O} \\
\sim 20 \% \mathrm{CO} 2\end{array}$ \\
\hline EB9017-01 & Oval/ Isolated & Primary & $\sim 20$ & -56.7 & -14.2 & 5.6 & 286.2 & 18.0 & $\begin{array}{l}\sim 65 \% \mathrm{H} 2 \mathrm{O} \\
\sim 30 \% \mathrm{CO} 2\end{array}$ \\
\hline EB9017-01 & $\begin{array}{c}\text { Subrounded/ } \\
\text { Scattered Cluster }\end{array}$ & Primary & $\sim 20$ & -56.9 & -16.1 & -1.2 & 224.2 & 19.9 & $\begin{array}{l}\sim 30 \% \mathrm{H} 2 \mathrm{O} \\
\sim 15 \% \mathrm{CO} 2\end{array}$ \\
\hline
\end{tabular}

\section{CHEVRON ZONE (Barren)}

\begin{tabular}{|c|c|c|c|c|c|c|c|c|c|}
\hline Sample & $\begin{array}{l}\text { Occurrence of } \\
\text { fluid inclusions }\end{array}$ & $\begin{array}{l}\text { Primary / } \\
\text { Secondary }\end{array}$ & $\begin{array}{c}\text { Size } \\
(\mu \mathrm{m})\end{array}$ & $\begin{array}{l}\mathbf{T}_{\mathrm{m}-\mathrm{CO} 2} \\
\left({ }^{\circ} \mathrm{C}\right)\end{array}$ & $\begin{array}{l}\mathbf{T}_{\mathrm{m}-\mathrm{H} 2 \mathrm{O}} \\
\left({ }^{\circ} \mathrm{C}\right)\end{array}$ & $\begin{array}{l}\mathrm{T}_{\mathrm{h}-\mathrm{CO} 2} \\
\left({ }^{\circ} \mathrm{C}\right)\end{array}$ & $\begin{array}{l}\mathbf{T}_{\mathrm{h}-\mathrm{H} 2 \mathrm{O}} \\
\left({ }^{\circ} \mathrm{C}\right)\end{array}$ & $\begin{array}{l}\mathrm{Wt} \% \\
\mathrm{NaCl}\end{array}$ & Vol \% \\
\hline EB9017-02 & Angular/Isolated & Primary & $\sim 25$ & -56.3 & -8.4 & 17.7 & 243.7 & 12.1 & $\begin{array}{l}\sim 65 \% \mathrm{H} 2 \mathrm{O} \\
\sim 35 \% \mathrm{CO} 2\end{array}$ \\
\hline EB9017-02 & Angular/Isolated & Primary & $\sim 25$ & -56.5 & -9.8 & 21.5 & 292.6 & 13.7 & $\begin{array}{l}\sim 30 \% \mathrm{H} 2 \mathrm{O} \\
\sim 20 \% \mathrm{CO} 2\end{array}$ \\
\hline EB9017-02 & $\begin{array}{l}\text { Oval/ Scattered } \\
\text { Cluster }\end{array}$ & Primary & $\sim 15$ & -56.2 & & -2.4 & & & $\sim 25 \% \mathrm{CO} 2$ \\
\hline EB9017-02 & Elongate/ Isolated & Primary & $\sim 15$ & -55.8 & -10.2 & 21.2 & $277.1 \mathrm{D}$ & 14.4 & $\begin{array}{l}\sim 60 \% \mathrm{H} 2 \mathrm{O} \\
\sim 35 \% \mathrm{CO} 2\end{array}$ \\
\hline EB9017-02 & $\begin{array}{c}\text { Angular/ Scattered } \\
\text { Cluster }\end{array}$ & Primary & $\sim 45$ & -55.8 & & 7.2 & & & $\sim 30 \% \mathrm{CO} 2$ \\
\hline EB9017-02 & $\begin{array}{l}\text { Angular/ Scattered } \\
\text { Cluster }\end{array}$ & Primary & $\sim 40$ & -56.0 & -12.0 & 7.1 & $246.4 \mathrm{D}$ & 16.0 & $\begin{array}{l}\sim 55 \% \mathrm{H} 2 \mathrm{O} \\
\sim 35 \% \mathrm{CO} 2\end{array}$ \\
\hline EB9017-02 & $\begin{array}{l}\text { Oval/ Scattered } \\
\text { Cluster }\end{array}$ & Primary & $\sim 15$ & -55.9 & -10.4 & 6.9 & 299.2 & 14.4 & $\begin{array}{l}\sim 35 \% \mathrm{H} 2 \mathrm{O} \\
\sim 25 \% \mathrm{CO} 2\end{array}$ \\
\hline EB9017-02 & Oval/ Isolated & Primary & $\sim 15$ & -56.1 & -15.8 & 6.0 & $269.7 \mathrm{D}$ & 19.4 & $\begin{array}{l}\sim 55 \% \mathrm{H} 2 \mathrm{O} \\
\sim 40 \% \mathrm{CO} 2\end{array}$ \\
\hline EB9017-02 & Oval/ Trail & Secondary & $\sim 8$ & -56.7 & -12.5 & 7.4 & $173.4 \mathrm{D}$ & 16.2 & $\begin{array}{l}\sim 65 \% \mathrm{H} 2 \mathrm{O} \\
\sim 25 \% \mathrm{CO} 2\end{array}$ \\
\hline EB9017-02 & Oval/ Trail & Secondary & $\sim 12$ & & & & & & \\
\hline EB9017-02 & $\begin{array}{l}\text { Subrounded/ } \\
\text { Isolated }\end{array}$ & Primary & $\sim 40$ & -55.6 & -12.6 & 4.9 & $196.4 \mathrm{D}$ & 16.3 & $\begin{array}{l}\sim 60 \% \mathrm{H} 2 \mathrm{O} \\
\sim 15 \% \mathrm{CO} 2\end{array}$ \\
\hline EB9017-02 & $\begin{array}{c}\text { Angular/ Scattered } \\
\text { Cluster }\end{array}$ & Primary & $\sim 20$ & -55.7 & -12.3 & 3.1 & $237.9 \mathrm{D}$ & 16.1 & $\begin{array}{l}\sim 80 \% \mathrm{H} 2 \mathrm{O} \\
\sim 15 \% \mathrm{CO} 2\end{array}$ \\
\hline
\end{tabular}




\begin{tabular}{|c|c|c|c|c|c|c|c|c|c|}
\hline EB9017-02 & $\begin{array}{c}\text { Subrounded/ } \\
\text { Scattered Cluster }\end{array}$ & Primary & $\sim 15$ & -55.6 & -14.5 & 7.6 & $233.7 \mathrm{D}$ & 18.2 & $\begin{array}{l}\sim 80 \% \mathrm{H} 2 \mathrm{O} \\
\sim 15 \% \mathrm{CO} 2\end{array}$ \\
\hline EB9017-02 & $\begin{array}{c}\text { Angular/ Scattered } \\
\text { Cluster }\end{array}$ & Primary & $\sim 30$ & -55.8 & -15.6 & 5.1 & $192.3 \mathrm{D}$ & 19.3 & $\begin{array}{l}\sim 80 \% \mathrm{H} 2 \mathrm{O} \\
\sim 15 \% \mathrm{CO} 2\end{array}$ \\
\hline EB9017-02 & Angualr/ Cluster & Primary & $\sim 20$ & -55.7 & -13.8 & 7.1 & 384.4 & 17.6 & $\begin{array}{l}\sim 75 \% \mathrm{H} 2 \mathrm{O} \\
\sim 15 \% \mathrm{CO} 2\end{array}$ \\
\hline EB9017-02 & $\begin{array}{l}\text { Subrounded/ } \\
\text { Scattered Cluster }\end{array}$ & Primary & $\sim 15$ & -55.7 & -12.4 & 6.3 & $256.7 \mathrm{D}$ & 16.1 & $\begin{array}{l}\sim 80 \% \mathrm{H} 2 \mathrm{O} \\
\sim 20 \% \mathrm{CO} 2\end{array}$ \\
\hline EB9017-02 & Subround/Trail & Secondary & $\sim 15$ & -59.4 & -7.4 & 14.3 & 206.4 & 10.9 & $\begin{array}{l}\sim 20 \% \mathrm{CO} 2 \\
\sim 35 \% \mathrm{H} 2 \mathrm{O}\end{array}$ \\
\hline EB9017-02 & Round/Rough Trail & Secondary & $\sim 20$ & -57.2 & -8.2 & 14.2 & 183.4 & 12.1 & $\begin{array}{l}\sim 20 \% \mathrm{CO} 2 \\
\sim 30 \% \mathrm{H} 2 \mathrm{O}\end{array}$ \\
\hline EB9017-02 & $\begin{array}{c}\text { Subround/ Rough } \\
\text { Trail }\end{array}$ & Secondary & $\sim 35$ & -59.0 & & 15.2 & & & $\sim 25 \% \mathrm{CO} 2$ \\
\hline EB9017-02 & $\begin{array}{c}\text { Elongate/ Rough } \\
\text { Trail }\end{array}$ & Secondary & $\sim 25$ & -58.7 & & -1.3 & & & $\sim 35 \% \mathrm{CO} 2$ \\
\hline EB9017-02 & $\begin{array}{c}\text { Elongate/ Rough } \\
\text { Trail }\end{array}$ & Secondary & $\sim 20$ & -58.9 & & 7.1 & & & $\sim 25 \% \mathrm{CO} 2$ \\
\hline EB9017-02 & $\begin{array}{c}\text { Subround/ } \\
\text { Scattered Trail }\end{array}$ & Secondary & $\sim 20$ & -59.1 & -8.7 & 14.6 & 242.1 & 12.6 & $\begin{array}{l}\sim 20 \% \mathrm{CO} 2 \\
\sim 30 \% \mathrm{H} 2 \mathrm{O}\end{array}$ \\
\hline
\end{tabular}

\section{Marboy (Mineralized - 1.127oz/t)}

\begin{tabular}{|c|c|c|c|c|c|c|c|c|c|}
\hline Sample & $\begin{array}{l}\text { Occurrence of } \\
\text { fluid inclusions }\end{array}$ & $\begin{array}{l}\text { Primary / } \\
\text { Secondary }\end{array}$ & $\begin{array}{l}\text { Size } \\
(\mu \mathrm{m})\end{array}$ & $\begin{array}{l}\mathrm{T}_{\mathrm{m}-\mathrm{CO} 2} \\
\left({ }^{\circ} \mathrm{C}\right)\end{array}$ & $\begin{array}{l}\mathbf{T}_{\mathrm{m}-\mathrm{H} 2 \mathrm{O}} \\
\left({ }^{\circ} \mathrm{C}\right)\end{array}$ & $\begin{array}{l}\mathrm{T}_{\mathrm{h}-\mathrm{CO} 2} \\
\left({ }^{\circ} \mathrm{C}\right)\end{array}$ & $\begin{array}{l}\mathrm{T}_{\mathrm{h}-\mathrm{H} 2 \mathrm{O}} \\
\left({ }^{\circ} \mathrm{C}\right)\end{array}$ & $\begin{array}{l}\mathrm{Wt} \% \\
\mathrm{NaCl}\end{array}$ & Vol \% \\
\hline MB891-06 & Angular/ Isolated & Primary & $\sim 15$ & -57.7 & -16.9 & 15.0 & $292.4 \mathrm{D}$ & 20.0 & $\begin{array}{l}\sim 70 \% \mathrm{H} 2 \mathrm{O} \\
\sim 15 \% \mathrm{CO} 2\end{array}$ \\
\hline MB891-06 & $\begin{array}{c}\text { Subrounded/ } \\
\text { Scattered Cluster }\end{array}$ & Primary & $\sim 20$ & -56.0 & -12.1 & 17.0 & $297.6 \mathrm{D}$ & 15.8 & $\begin{array}{l}\sim 65 \% \mathrm{H} 2 \mathrm{O} \\
\sim 20 \% \mathrm{CO} 2\end{array}$ \\
\hline MB891-06 & $\begin{array}{c}\text { Angular/Scattered } \\
\text { Cluster }\end{array}$ & Primary & $\sim 25$ & -56.1 & -17.1 & 16.8 & $299.4 \mathrm{D}$ & 20.1 & $\begin{array}{l}\sim 75 \% \mathrm{H} 2 \mathrm{O} \\
\sim 15 \% \mathrm{CO} 2\end{array}$ \\
\hline MB891-06 & $\begin{array}{c}\text { Subrounded/ } \\
\text { Scattered Cluster }\end{array}$ & Primary & $\sim 45$ & -57.1 & & 4.4 & & & $\sim 25 \% \mathrm{CO} 2$ \\
\hline MB891-06 & $\begin{array}{l}\text { Oval/ Scattered } \\
\text { Cluster }\end{array}$ & Primary & $\sim 20$ & -56.7 & -15.9 & 16.2 & $398.8 \mathrm{D}$ & 19.6 & $\begin{array}{l}\sim 60 \% \mathrm{H} 2 \mathrm{O} \\
\sim 20 \% \mathrm{CO} 2\end{array}$ \\
\hline MB891-06 & $\begin{array}{c}\text { Subrounded/ } \\
\text { Scattered Cluster }\end{array}$ & Primary & $\sim 20$ & -59.1 & & -3.0 & & & $\sim 30 \% \mathrm{CO} 2$ \\
\hline MB891-06 & $\begin{array}{l}\text { Oval/ Scattered } \\
\text { Cluster }\end{array}$ & Primary & $\sim 20$ & -58.1 & -15.1 & 10.8 & $293.2 \mathrm{D}$ & 19.1 & $\begin{array}{l}\sim 55 \% \mathrm{H} 2 \mathrm{O} \\
\sim 30 \% \mathrm{CO} 2\end{array}$ \\
\hline MB891-06 & $\begin{array}{l}\text { Oval/ Scattered } \\
\text { Cluster }\end{array}$ & Primary & $\sim 15$ & -57.7 & -12.3 & 6.1 & $304.7 \mathrm{D}$ & 16.1 & $\begin{array}{l}\sim 60 \% \mathrm{H} 2 \mathrm{O} \\
\sim 15 \% \mathrm{CO} 2\end{array}$ \\
\hline MB891-06 & Angular/Isolated & Primary & $\sim 12$ & -57.5 & -11.8 & 17.9 & $315.7 \mathrm{D}$ & 15.8 & $\begin{array}{l}\sim 70 \% \mathrm{H} 2 \mathrm{O} \\
\sim 30 \% \mathrm{CO} 2\end{array}$ \\
\hline MB891-06 & $\begin{array}{l}\text { Oval/ Scattered } \\
\text { Cluster }\end{array}$ & Primary & $\sim 20$ & -58.1 & & 11.7 & & & $\sim 30 \% \mathrm{CO} 2$ \\
\hline MB891-06 & $\begin{array}{c}\text { Angular/Scattered } \\
\text { Cluster }\end{array}$ & Primary & $\sim 25$ & -58.0 & -22.4 & 5.0 & $325.2 \mathrm{D}$ & 24.0 & $\begin{array}{l}\sim 40 \% \mathrm{H} 2 \mathrm{O} \\
\sim 20 \% \mathrm{CO} 2\end{array}$ \\
\hline MB891-06 & Oval/ Isolated & Primary & $\sim 15$ & -57.7 & -16.5 & 11.9 & $305.6 \mathrm{D}$ & 20.1 & $\begin{array}{l}\sim 70 \% \mathrm{H} 2 \mathrm{O} \\
\sim 15 \% \mathrm{CO} 2\end{array}$ \\
\hline MB891-06 & $\begin{array}{l}\text { Oval/ Scattered } \\
\text { Cluster }\end{array}$ & Primary & $\sim 15$ & -58.4 & & 9.6 & & & $\sim 25 \% \mathrm{CO} 2$ \\
\hline MB891-06 & $\begin{array}{l}\text { Oval/ Scattered } \\
\text { Cluster }\end{array}$ & Primary & $\sim 20$ & -57.4 & & 19.0 & & & $\sim 20 \% \mathrm{CO} 2$ \\
\hline
\end{tabular}




\begin{tabular}{|c|c|c|c|c|c|c|c|c|c|}
\hline \multicolumn{10}{|c|}{ Marboy (Barren) } \\
\hline Sample & $\begin{array}{l}\text { Occurrence of } \\
\text { fluid inclusions }\end{array}$ & $\begin{array}{l}\text { Primary / } \\
\text { Secondary }\end{array}$ & $\begin{array}{l}\text { Size } \\
(\mu \mathrm{m})\end{array}$ & $\begin{array}{c}\mathrm{T}_{\mathrm{m}-\mathrm{CO} 2} \\
\left({ }^{\circ} \mathrm{C}\right)\end{array}$ & $\begin{array}{c}\mathrm{T}_{\mathrm{m}-\mathrm{H} 2 \mathrm{O}} \\
\left({ }^{\circ} \mathrm{C}\right)\end{array}$ & $\begin{array}{c}\mathrm{T}_{\mathrm{h}-\mathrm{CO} 2} \\
\left({ }^{\circ} \mathrm{C}\right)\end{array}$ & $\begin{array}{c}\mathrm{T}_{\mathrm{h}-\mathrm{H} 2 \mathrm{O}} \\
\left({ }^{\circ} \mathrm{C}\right)\end{array}$ & $\begin{array}{l}\text { Wt \% } \\
\text { NaCl }\end{array}$ & Vol \% \\
\hline MB10034-03 & $\begin{array}{c}\text { Elongate/ Rough } \\
\text { Trail }\end{array}$ & Secondary & $\sim 15$ & -57.6 & -11.3 & 8.1 & 277.4 & 15.3 & $\begin{array}{l}\sim 35 \% \mathrm{H} 2 \mathrm{O} \\
\sim 25 \% \mathrm{CO} 2\end{array}$ \\
\hline MB10034-03 & Oval/ Angled Trail & Secondary & $\sim 20$ & -58.6 & -10.2 & 7.8 & 253.9 & 14.4 & $\begin{array}{l}\sim 45 \% \mathrm{H} 2 \mathrm{O} \\
\sim 50 \% \mathrm{CO} 2\end{array}$ \\
\hline MB10034-03 & $\begin{array}{c}\text { Elongate/ Angled } \\
\text { Trail }\end{array}$ & Secondary & $\sim 30$ & -57.1 & -13.3 & 8.2 & $281.6 \mathrm{D}$ & 17.0 & $\begin{array}{l}\sim 80 \% \mathrm{H} 2 \mathrm{O} \\
\sim 20 \% \mathrm{CO} 2\end{array}$ \\
\hline MB10034-03 & $\begin{array}{c}\text { Elongate/ Angled } \\
\text { Trail }\end{array}$ & Secondary & $\sim 20$ & -57.4 & -10.6 & 8.4 & 271.4 & 14.5 & $\begin{array}{l}\sim 40 \% \mathrm{H} 2 \mathrm{O} \\
\sim 25 \% \mathrm{CO} 2\end{array}$ \\
\hline MB10034-03 & $\begin{array}{c}\text { Very Elongate/ } \\
\text { Angled Trail }\end{array}$ & Secondary & $\begin{array}{c}\sim 8 \times 5 \\
0\end{array}$ & -56.9 & -9.3 & 1.4 & $212.7 \mathrm{D}$ & 13.3 & $\begin{array}{l}\sim 30 \% \mathrm{H} 2 \mathrm{O} \\
\sim 15 \% \mathrm{CO} 2\end{array}$ \\
\hline MB10034-03 & $\begin{array}{l}\text { Rough Elongate/ } \\
\text { Angled Trail }\end{array}$ & Secondary & $\sim 20$ & -57.1 & -8.8 & 12.4 & $221.8 \mathrm{D}$ & 12.8 & $\begin{array}{l}\sim 55 \% \mathrm{H} 2 \mathrm{O} \\
\sim 30 \% \mathrm{CO} 2\end{array}$ \\
\hline MB10034-03 & $\begin{array}{c}\text { Elongate/ Scattered } \\
\text { Cluster }\end{array}$ & Primary & $\sim 20$ & -57.6 & & 1.6 & & & $\sim 30 \% \mathrm{CO} 2$ \\
\hline MB10034-03 & $\begin{array}{c}\text { Elongate/ Angled } \\
\text { Trail }\end{array}$ & Secondary & $\sim 20$ & -57.4 & -6.8 & 8.7 & 256.5 & 10.2 & $\begin{array}{l}\sim 30 \% \mathrm{H} 2 \mathrm{O} \\
\sim 15 \% \mathrm{CO} 2\end{array}$ \\
\hline MB10034-03 & $\begin{array}{c}\text { Subrounded/ } \\
\text { Scattered Cluster }\end{array}$ & Primary & $\sim 18$ & -58.6 & -10.1 & -13.2 & $232.7 \mathrm{D}$ & 13.5 & $\begin{array}{l}\sim 35 \% \mathrm{H} 2 \mathrm{O} \\
\sim 30 \% \mathrm{CO} 2\end{array}$ \\
\hline MB10034-03 & $\begin{array}{c}\text { Angular/ Scattered } \\
\text { Cluster }\end{array}$ & Primary & $\sim 25$ & -56.6 & & 11.4 & & & $\sim 20 \% \mathrm{CO} 2$ \\
\hline MB10034-03 & $\begin{array}{c}\text { Angular/ Scattered } \\
\text { Cluster }\end{array}$ & Primary & $\sim 30$ & -56.7 & & 9.6 & & & $\sim 30 \% \mathrm{CO} 2$ \\
\hline MB10034-03 & $\begin{array}{l}\text { Elongate Oval/ } \\
\text { Scattered Cluster }\end{array}$ & Primary & $\sim 20$ & -57.1 & & 13.3 & & & $\sim 25 \% \mathrm{CO} 2$ \\
\hline MB10034-03 & $\begin{array}{c}\text { Subrounded/ } \\
\text { Isolated }\end{array}$ & Primary & $\sim 18$ & -55.9 & & 26.3 & & & $\sim 60 \% \mathrm{CO} 2$ \\
\hline MB10034-03 & $\begin{array}{c}\text { Oval/ Scattered } \\
\text { Cluster }\end{array}$ & Primary & $\sim 15$ & -57.2 & & 20.7 & & & $\sim 50 \% \mathrm{CO} 2$ \\
\hline MB10034-03 & $\begin{array}{c}\text { Subrounded/ } \\
\text { Scattered Cluster }\end{array}$ & Primary & $\sim 15$ & -56.9 & & 7.7 & & & $\sim 35 \% \mathrm{CO} 2$ \\
\hline MB10034-03 & Oval/ Isolated & Primary & $\sim 20$ & -57.3 & & 8.4 & & & $\sim 45 \% \mathrm{CO} 2$ \\
\hline MB10034-03 & Round/ Isolated & Primary & $\sim 15$ & -57.4 & & 12.8 & & & $\sim 40 \% \mathrm{CO} 2$ \\
\hline MB10034-03 & Round/ Isolated & Primary & $\sim 20$ & -57.5 & & 14.7 & & & $\sim 40 \% \mathrm{CO} 2$ \\
\hline MB10034-03 & $\begin{array}{c}\text { Angular/ Scattered } \\
\text { Cluster }\end{array}$ & Primary & $\sim 20$ & -57.2 & & 13.6 & & & $\sim 30 \% \mathrm{CO} 2$ \\
\hline MB10034-03 & Round/ Isolated & Primary & $\sim 15$ & -58.7 & & 19.8 & & & $\sim 25 \% \mathrm{CO} 2$ \\
\hline MB10034-03 & Oval/ Isolated & Primary & $\sim 12$ & -56.6 & & 13.6 & & & $\sim 35 \% \mathrm{CO} 2$ \\
\hline
\end{tabular}




\begin{tabular}{|c|c|c|c|c|c|c|c|c|c|}
\hline \multicolumn{10}{|c|}{ McFinley (Barren) } \\
\hline Sample & $\begin{array}{l}\text { Occurrence of } \\
\text { fluid inclusions }\end{array}$ & $\begin{array}{l}\text { Primary / } \\
\text { Secondary }\end{array}$ & $\begin{array}{l}\text { Size } \\
(\mu \mathrm{m})\end{array}$ & $\begin{array}{c}\mathrm{T}_{\mathrm{m}-\mathrm{CO} 2} \\
\left({ }^{\circ} \mathrm{C}\right)\end{array}$ & $\begin{array}{c}\mathbf{T}_{\mathrm{m}-\mathrm{H} 2 \mathrm{O}} \\
\left({ }^{\circ} \mathrm{C}\right)\end{array}$ & $\begin{array}{c}\mathrm{T}_{\mathrm{h}-\mathrm{CO} 2} \\
\left({ }^{\circ} \mathrm{C}\right)\end{array}$ & $\begin{array}{c}\mathrm{T}_{\mathrm{h}-\mathrm{H} 2 \mathrm{O}} \\
\left({ }^{\circ} \mathrm{C}\right)\end{array}$ & $\begin{array}{c}\text { Wt \% } \\
\text { NaCl- } \\
\mathrm{MgCl}_{2}\end{array}$ & Vol \% \\
\hline EB10048-02 & $\begin{array}{c}\text { Subrounded/ } \\
\text { Scattered Cluster }\end{array}$ & Primary & $\sim 35$ & -56.6 & & -3.1 & & & $\sim 20 \% \mathrm{CO} 2$ \\
\hline EB10048-02 & $\begin{array}{l}\text { Oval/ Scattered } \\
\text { Cluster }\end{array}$ & Primary & $\sim 20$ & -56.7 & & -5.6 & & & $\sim 15 \% \mathrm{CO} 2$ \\
\hline EB10048-02 & $\begin{array}{c}\text { Round/ Scattered } \\
\text { Cluster }\end{array}$ & Primary & $\sim 20$ & -56.2 & & 2.1 & & & $\sim 35 \% \mathrm{CO} 2$ \\
\hline EB10048-02 & $\begin{array}{c}\text { Subrounded/ } \\
\text { Scattered Cluster }\end{array}$ & Primary & $\sim 20$ & -56.0 & & 5.8 & & & $\sim 30 \% \mathrm{CO} 2$ \\
\hline EB10048-02 & $\begin{array}{c}\text { Oval/ Scattered } \\
\text { Cluster }\end{array}$ & Primary & $\sim 10$ & -56.3 & & 2.4 & & & $\sim 30 \% \mathrm{CO} 2$ \\
\hline EB10048-02 & $\begin{array}{c}\text { Subrounded/ } \\
\text { Scattered Cluster }\end{array}$ & Primary & $\sim 15$ & -57.1 & & 14.7 & & & $\sim 20 \% \mathrm{CO} 2$ \\
\hline EB10048-02 & Elongate/ Trail & Secondary & $\sim 15$ & -56.9 & & 2.3 & & & $\sim 25 \% \mathrm{CO} 2$ \\
\hline EB10048-02 & Subrounded/ Trail & Secondary & $\sim 10$ & -57.2 & & 8.2 & & & $\sim 35 \% \mathrm{CO} 2$ \\
\hline EB10048-02 & Subrounded/ Trail & Secondary & $\sim 8$ & -56.7 & & 1.2 & & & $\sim 30 \% \mathrm{CO} 2$ \\
\hline EB10048-02 & Round/ Trail & Secondary & $\sim 8$ & -56.9 & & 5.4 & & & $\sim 35 \% \mathrm{CO} 2$ \\
\hline EB10048-02 & $\begin{array}{l}\text { Round/ Scattered } \\
\text { Cluster }\end{array}$ & Primary & $\sim 18$ & -55.9 & & -9.4 & & & $\sim 25 \% \mathrm{CO} 2$ \\
\hline EB10048-02 & $\begin{array}{c}\text { Round/ Isolated } \\
\text { Cluster }\end{array}$ & Primary & $\sim 15$ & -55.8 & & 9.6 & & & $\sim 40 \% \mathrm{CO} 2$ \\
\hline EB10048-02 & $\begin{array}{l}\text { Angular/ Isolated } \\
\text { Cluster }\end{array}$ & Primary & $\sim 20$ & -55.6 & & 13.6 & & & $\sim 25 \% \mathrm{CO} 2$ \\
\hline EB10048-02 & $\begin{array}{c}\text { Round/ Scattered } \\
\text { Cluster }\end{array}$ & Primary & $\sim 18$ & -55.8 & & -3.8 & & & $\sim 20 \% \mathrm{CO} 2$ \\
\hline EB10048-02 & Round/ Trail & Secondary & $\sim 10$ & -56.4 & & 6.6 & & & $\sim 20 \% \mathrm{CO} 2$ \\
\hline EB10048-02 & Subrounded/ Trail & Secondary & $\sim 12$ & -56.3 & & 4.8 & & & $\sim 25 \% \mathrm{CO} 2$ \\
\hline EB10048-02 & $\begin{array}{l}\text { Oval/ Isolated } \\
\text { Cluster }\end{array}$ & Primary & $\sim 20$ & -56.0 & & 8.7 & & & $\sim 30 \% \mathrm{CO} 2$ \\
\hline EB10048-02 & $\begin{array}{c}\text { Subrounded/ } \\
\text { Scattered Cluster }\end{array}$ & Primary & $\sim 20$ & -56.1 & & 4.8 & & & $\sim 30 \% \mathrm{CO} 2$ \\
\hline \multicolumn{10}{|c|}{ McFinley (Mineralized 1.880z/t) } \\
\hline Sample & $\begin{array}{l}\text { Occurrence of } \\
\text { fluid inclusions }\end{array}$ & $\begin{array}{l}\text { Primary / } \\
\text { Secondary }\end{array}$ & $\begin{array}{c}\text { Size } \\
(\mu \mathrm{m})\end{array}$ & $\begin{array}{c}\mathrm{T}_{\mathrm{m}-\mathrm{CO} 2} \\
\left({ }^{\circ} \mathrm{C}\right)\end{array}$ & $\begin{array}{c}\mathbf{T}_{\mathrm{m}-\mathrm{H} 2 \mathrm{O}} \\
\left({ }^{\circ} \mathrm{C}\right)\end{array}$ & $\begin{array}{c}\mathrm{T}_{\mathrm{h}-\mathrm{CO} 2} \\
\left({ }^{\circ} \mathrm{C}\right)\end{array}$ & $\begin{array}{c}\mathbf{T}_{\mathrm{h}-\mathrm{H} 2 \mathrm{O}} \\
\left({ }^{\circ} \mathrm{C}\right)\end{array}$ & $\begin{array}{l}\text { Wt } \% \\
\mathrm{NaCl}\end{array}$ & Vol \% \\
\hline EB10048-03 & Oval/ Weak Trail & Secondary & $\sim 10$ & & -14.5 & & 349.8 & 18.2 & $\sim 35 \% \mathrm{H} 2 \mathrm{O}$ \\
\hline EB10048-03 & Elongate/ Isolated & Primary? & $\begin{array}{c}\sim 10 \mathrm{x} \\
30\end{array}$ & -58.0 & & 13.7 & & & $\sim 25 \% \mathrm{CO} 2$ \\
\hline EB10048-03 & $\begin{array}{c}\text { Angular/ Scattered } \\
\text { Cluster }\end{array}$ & Primary & $\sim 35$ & -58.9 & & 16.2 & & & $\sim 50 \% \mathrm{CO} 2$ \\
\hline EB10048-03 & Angular/ Isolated & Primary & $\sim 30$ & -57.6 & & 16.8 & & & $\sim 50 \% \mathrm{CO} 2$ \\
\hline EB10048-03 & $\begin{array}{c}\text { Oval/ Scattered } \\
\text { Cluster }\end{array}$ & Primary & $\sim 15$ & -57.9 & & 14.6 & & & $\sim 30 \% \mathrm{CO} 2$ \\
\hline
\end{tabular}




\begin{tabular}{|c|c|c|c|c|c|c|c|c|c|}
\hline EB10048-03 & $\begin{array}{c}\text { Elongated/ Angled } \\
\text { Trail }\end{array}$ & Secondary & $\sim 15$ & -58.4 & & 4.3 & & & $\sim 20 \% \mathrm{CO} 2$ \\
\hline EB10048-03 & $\begin{array}{l}\text { Subrounded/ } \\
\text { Rough Trail }\end{array}$ & Secondary & $\sim 15$ & -56.3 & & 16.7 & & & $\sim 40 \% \mathrm{CO} 2$ \\
\hline EB10048-03 & Oval/ Isolated & Primary & $\sim 12$ & -58.7 & & 9.1 & & & $\sim 20 \% \mathrm{CO} 2$ \\
\hline EB10048-03 & $\begin{array}{l}\text { Oval/ Scattered } \\
\text { Cluster }\end{array}$ & Primary & $\sim 15$ & -56.7 & & 8.8 & & & $\sim 35 \% \mathrm{CO} 2$ \\
\hline EB10048-03 & $\begin{array}{l}\text { Subrounded/ } \\
\text { Rough Trail }\end{array}$ & $\begin{array}{l}\text { Pseudosec } \\
\text { ondary? }\end{array}$ & $\sim 15$ & & -5.4 & & 345.2 & 8.1 & $\sim 65 \% \mathrm{H} 2 \mathrm{O}$ \\
\hline EB10048-03 & $\begin{array}{c}\text { Angular/ Scattered } \\
\text { Cluster }\end{array}$ & Primary & $\sim 20$ & & -12.5 & & $421.5 \mathrm{D}$ & 16.2 & $\sim 40 \% \mathrm{H} 2 \mathrm{O}$ \\
\hline EB10048-03 & $\begin{array}{c}\text { Subrounded/ } \\
\text { Scattered Cluster }\end{array}$ & Primary & $\sim 30$ & -58.3 & & 11.2 & & & $\sim 40 \% \mathrm{CO} 2$ \\
\hline EB10048-03 & $\begin{array}{c}\text { Elongate/ Rough } \\
\text { Trail }\end{array}$ & Secondary & $\sim 20$ & -56.8 & & 10.4 & & & $\sim 25 \% \mathrm{CO} 2$ \\
\hline EB10048-03 & $\begin{array}{c}\text { Subrounded/ Large } \\
\text { Cluster }\end{array}$ & Secondary & $\sim 15$ & -56.9 & & 16.2 & & & $\sim 35 \% \mathrm{CO} 2$ \\
\hline EB10048-03 & $\begin{array}{l}\text { Subrounded/ } \\
\text { isolated }\end{array}$ & Primary & $\sim 15$ & -58.2 & & 15.9 & & & $\sim 40 \% \mathrm{CO} 2$ \\
\hline EB10048-03 & $\begin{array}{l}\text { Subrounded/ } \\
\text { isolated }\end{array}$ & Primary & $\sim 15$ & & -10.3 & & 559.4 & 14.4 & $\sim 15 \% \mathrm{H} 2 \mathrm{O}$ \\
\hline EB10048-03 & Oval/Small Cluster & Primary & $\sim 25$ & -58.3 & & -7.7 & & & $\sim 35 \% \mathrm{CO} 2$ \\
\hline EB10048-03 & $\begin{array}{l}\text { Oval/ Scattered } \\
\text { Cluster }\end{array}$ & Primary & $\sim 15$ & -57.8 & & 5.3 & & & $\sim 25 \% \mathrm{CO} 2$ \\
\hline EB10048-03 & $\begin{array}{l}\text { Subrounded/ } \\
\text { Rough Trail }\end{array}$ & Secondary & $\sim 15$ & -57.8 & & 12.8 & & & $\sim 15 \% \mathrm{CO} 2$ \\
\hline EB10048-03 & Oval/ Rough Trail & Secondary & $\sim 12$ & -56.0 & & 17.2 & & & $\sim 30 \% \mathrm{CO} 2$ \\
\hline EB10048-03 & Oval/ Rough Trail & Secondary & $\sim 20$ & -57.2 & & 16.7 & & & $\sim 15 \% \mathrm{CO} 2$ \\
\hline \multicolumn{10}{|c|}{ Abino (Barren) } \\
\hline Sample & $\begin{array}{r}\text { Occurrence of } \\
\text { fluid inclusions }\end{array}$ & $\begin{array}{c}\text { Primary / } \\
\text { Secondary }\end{array}$ & $\begin{array}{l}\text { Size } \\
(\mu \mathrm{m})\end{array}$ & $\begin{array}{l}\mathrm{T}_{\mathrm{m}-\mathrm{CO} 2} \\
\left({ }^{\circ} \mathrm{C}\right)\end{array}$ & $\begin{array}{l}\mathrm{T}_{\mathrm{m}-\mathrm{H} 2 \mathrm{O}} \\
\left({ }^{\circ} \mathrm{C}\right)\end{array}$ & $\begin{array}{l}\mathrm{T}_{\mathrm{h}-\mathrm{CO} 2} \\
\left({ }^{\circ} \mathrm{C}\right)\end{array}$ & $\begin{array}{l}\mathrm{T}_{\mathrm{h}-\mathrm{H} 2 \mathrm{O}} \\
\left({ }^{\circ} \mathrm{C}\right)\end{array}$ & $\begin{array}{l}\mathrm{Wt} \% \\
\mathrm{NaCl}\end{array}$ & Vol \% \\
\hline ABU51-01 & Elongate/ Scattered & Primary & $\sim 18$ & -58.7 & & -0.3 & & & $\sim 35 \% \mathrm{CO} 2$ \\
\hline ABU51-01 & $\begin{array}{l}\text { Subrounded/ } \\
\text { Scattered }\end{array}$ & Primary & $\sim 30$ & -57.1 & & 14.2 & & & $\sim 35 \% \mathrm{CO} 2$ \\
\hline ABU51-01 & Elongate/ Trail & Secondary & $\sim 20$ & -57.6 & & 16.9 & & & $\sim 30 \% \mathrm{CO} 2$ \\
\hline ABU51-01 & Oval Trail & Secondary & $\sim 15$ & -57.4 & & 18.8 & & & $\sim 45 \% \mathrm{CO} 2$ \\
\hline ABU51-01 & $\begin{array}{c}\text { Very Elongate/ } \\
\text { Trail }\end{array}$ & Secondary & $\begin{array}{c}\sim 7 \times 1 \\
5\end{array}$ & -56.8 & & 17.2 & & & $\sim 35 \% \mathrm{CO} 2$ \\
\hline ABU51-01 & Oval/ Trail & Secondary & $\sim 12$ & -56.7 & & 14.8 & & & $\sim 45 \% \mathrm{CO} 2$ \\
\hline ABU51-01 & $\begin{array}{l}\text { Round/ Scattered } \\
\text { Cluster }\end{array}$ & Secondary & $\sim 18$ & & -12.2 & & 194.6 & 15.8 & $\sim 35 \% \mathrm{H} 2 \mathrm{O}$ \\
\hline ABU51-01 & $\begin{array}{c}\text { Elongate/ Scattered } \\
\text { Cluster }\end{array}$ & Primary & $\sim 25$ & & -11.5 & & 266.4 & 14.5 & $\sim 40 \% \mathrm{H} 2 \mathrm{O}$ \\
\hline ABU51-01 & $\begin{array}{l}\text { Oval/ Scattered } \\
\text { Cluster }\end{array}$ & Primary & $\sim 15$ & & -11.9 & & 259.7 & 15.9 & $\sim 30 \% \mathrm{H} 2 \mathrm{O}$ \\
\hline
\end{tabular}




\begin{tabular}{|c|c|c|c|c|c|c|c|c|c|}
\hline ABU51-01 & $\begin{array}{c}\text { Round/ Scattered } \\
\text { Cluster }\end{array}$ & Primary & $\sim 10$ & & -12.1 & & 271.2 & 15.9 & $\sim 35 \% \mathrm{H} 2 \mathrm{O}$ \\
\hline ABU51-01 & $\begin{array}{c}\text { Subrounded/ } \\
\text { Cluster Along Trail }\end{array}$ & Primary & $\sim 25$ & & -12.9 & & 291.4 & 16.5 & $\sim 40 \% \mathrm{H} 2 \mathrm{O}$ \\
\hline ABU51-01 & Oval/ Trail & Secondary & $\sim 25$ & -59.4 & -12.8 & 16.0 & 198.7 & 17.5 & $\begin{array}{l}\sim 45 \% \mathrm{H} 2 \mathrm{O} \\
\sim 50 \% \mathrm{CO} 2\end{array}$ \\
\hline ABU51-01 & Oval/ Isolated & Primary & $\sim 20$ & -59.7 & -13.1 & 18.6 & 312.6 & 17.1 & $\begin{array}{l}\sim 40 \% \mathrm{H} 2 \mathrm{O} \\
\sim 50 \% \mathrm{CO} 2\end{array}$ \\
\hline ABU51-01 & Oval/ Isolated & Primary & $\sim 15$ & -58.1 & -13.6 & 16.5 & 335.2 & 17.4 & $\begin{array}{l}\sim 35 \% \mathrm{H} 2 \mathrm{O} \\
\sim 45 \% \mathrm{CO} 2\end{array}$ \\
\hline ABU51-01 & $\begin{array}{c}\text { Elongate/ Rough } \\
\text { Trail }\end{array}$ & Secondary & $\begin{array}{c}\sim 5 \times 1 \\
8\end{array}$ & & -15.9 & & 196.4 & 19.4 & $\sim 45 \% \mathrm{H} 2 \mathrm{O}$ \\
\hline ABU51-01 & $\begin{array}{l}\text { Subrounded/ } \\
\text { Rough Trail }\end{array}$ & Secondary & $\sim 15$ & -58.3 & & 9.8 & & & $\sim 35 \% \mathrm{CO} 2$ \\
\hline
\end{tabular}

\section{Abino (Mineralized)}

\begin{tabular}{|c|c|c|c|c|c|c|c|c|c|}
\hline Sample & $\begin{array}{l}\text { Occurrence of } \\
\text { fluid inclusions }\end{array}$ & $\begin{array}{l}\text { Primary / } \\
\text { Secondary }\end{array}$ & $\begin{array}{l}\text { Size } \\
(\mu \mathrm{m})\end{array}$ & $\begin{array}{l}\mathbf{T}_{\mathrm{m}-\mathrm{CO} 2} \\
\left({ }^{\circ} \mathrm{C}\right)\end{array}$ & $\begin{array}{l}\mathrm{T}_{\mathrm{m}-\mathrm{H} 2 \mathrm{O}} \\
\left({ }^{\circ} \mathrm{C}\right)\end{array}$ & $\begin{array}{l}\mathrm{T}_{\mathrm{h}-\mathrm{CO} 2} \\
\left({ }^{\circ} \mathrm{C}\right)\end{array}$ & $\begin{array}{l}\mathrm{T}_{\mathrm{h}-\mathrm{H} 2 \mathrm{O}} \\
\left({ }^{\circ} \mathrm{C}\right)\end{array}$ & $\begin{array}{l}\mathrm{Wt} \% \\
\mathrm{NaCl}\end{array}$ & Vol \% \\
\hline ABU35-01 & $\begin{array}{c}\text { Subrounded/ } \\
\text { Scattered Cluster }\end{array}$ & Primary & $\sim 20$ & & -20.1 & & $189.7 \mathrm{D}$ & 22.5 & $\sim 15 \% \mathrm{H} 2 \mathrm{O}$ \\
\hline ABU35-01 & $\begin{array}{c}\text { Round/ Scattered } \\
\text { Cluster }\end{array}$ & Primary & $\sim 15$ & & -21.9 & & $245.6 \mathrm{D}$ & 23.4 & $\sim 20 \% \mathrm{H} 2 \mathrm{O}$ \\
\hline ABU35-01 & $\begin{array}{c}\text { Angular/ Scattered } \\
\text { Cluster }\end{array}$ & Primary & $\sim 30$ & & -20.4 & & 223.8 & 22.6 & $\sim 15 \% \mathrm{H} 2 \mathrm{O}$ \\
\hline ABU35-01 & $\begin{array}{c}\text { Round/ Scattered } \\
\text { Cluster }\end{array}$ & Secondary & $\sim 12$ & -56.9 & & -3.9 & & & $\sim 10 \% \mathrm{CO} 2$ \\
\hline ABU35-01 & $\begin{array}{c}\text { Elongate/ Scattered } \\
\text { Cluster }\end{array}$ & Secondary & $\sim 15$ & -57.4 & & -3.1 & & & $\sim 10 \% \mathrm{CO} 2$ \\
\hline ABU35-01 & $\begin{array}{c}\text { Elongate/ Scattered } \\
\text { Cluster }\end{array}$ & Secondary & $\sim 10$ & -56.6 & & 9.5 & & & $\sim 25 \% \mathrm{CO} 2$ \\
\hline ABU35-01 & $\begin{array}{l}\text { Round/ Scattered } \\
\text { Cluster }\end{array}$ & Primary & $\sim 12$ & -56.4 & & 21.9 & & & $\sim 20 \% \mathrm{CO} 2$ \\
\hline ABU35-01 & $\begin{array}{l}\text { Oval/ Scattered } \\
\text { Cluster }\end{array}$ & Primary & $\sim 15$ & & -18.7 & & 308.3 & 21.6 & $\sim 25 \% \mathrm{H} 2 \mathrm{O}$ \\
\hline ABU35-01 & $\begin{array}{c}\text { Subrounded/ } \\
\text { Scattered Cluster }\end{array}$ & Primary & $\sim 20$ & -56.6 & & 20.4 & & & $\sim 20 \% \mathrm{CO} 2$ \\
\hline \multicolumn{10}{|c|}{ Cochenour (Mineralized) } \\
\hline Sample & $\begin{array}{r}\text { Occurrence of } \\
\text { fluid inclusions }\end{array}$ & $\begin{array}{l}\text { Primary / } \\
\text { Secondary }\end{array}$ & $\begin{array}{l}\text { Size } \\
(\mu \mathrm{m})\end{array}$ & $\begin{array}{l}\mathrm{T}_{\mathrm{m}-\mathrm{CO} 2} \\
\left({ }^{\circ} \mathrm{C}\right)\end{array}$ & $\begin{array}{l}\mathrm{T}_{\mathrm{m}-\mathrm{H} 2 \mathrm{O}} \\
\left({ }^{\circ} \mathrm{C}\right)\end{array}$ & $\begin{array}{l}\mathrm{T}_{\mathrm{h}-\mathrm{CO} 2} \\
\left({ }^{\circ} \mathrm{C}\right)\end{array}$ & $\begin{array}{l}\mathrm{T}_{\mathrm{h}-\mathrm{H} 2 \mathrm{O}} \\
\left({ }^{\circ} \mathbf{C}\right)\end{array}$ & $\begin{array}{l}\text { Wt \% } \\
\text { NaCl }\end{array}$ & Vol \% \\
\hline $\mathrm{CO} 20 \mathrm{~L}-03$ & $\begin{array}{c}\text { Subrounded/ } \\
\text { Scattered Cluster }\end{array}$ & Primary & $\sim 10$ & & -12.8 & & 261.7 & 16.4 & $\sim 25 \% \mathrm{H} 2 \mathrm{O}$ \\
\hline CO20L-03 & $\begin{array}{c}\text { Subrounded/ } \\
\text { Scattered Cluster }\end{array}$ & Primary & $\sim 25$ & & -11.6 & & 306.5 & 14.6 & $\sim 15 \% \mathrm{H} 2 \mathrm{O}$ \\
\hline CO20L-03 & $\begin{array}{l}\text { Subrounded/ } \\
\text { Scattered Cluster }\end{array}$ & Primary & $\sim 20$ & & -15.1 & & 184.2 & 19.1 & $\sim 20 \% \mathrm{H} 2 \mathrm{O}$ \\
\hline CO20L-03 & $\begin{array}{l}\text { Oval/ Scattered } \\
\text { Cluster }\end{array}$ & Primary & $\sim 15$ & & -15.9 & & 241.3 & 19.4 & $\sim 20 \% \mathrm{H} 2 \mathrm{O}$ \\
\hline CO20L-03 & $\begin{array}{c}\text { Subrounded/ } \\
\text { Scattered Cluster }\end{array}$ & Primary & $\sim 20$ & & -13.8 & & 233.4 & 17.4 & $\sim 20 \% \mathrm{H} 2 \mathrm{O}$ \\
\hline
\end{tabular}




\begin{tabular}{|c|c|c|c|c|c|c|c|c|c|}
\hline CO20L-03 & $\begin{array}{c}\text { Oval/ Scattered } \\
\text { Trail }\end{array}$ & Secondary & $\sim 25$ & & -12.5 & & $371.2 \mathrm{D}$ & 16.2 & $\sim 15 \% \mathrm{H} 2 \mathrm{O}$ \\
\hline CO20L-03 & $\begin{array}{l}\text { Subrounded/ } \\
\text { Scattered Trail }\end{array}$ & Secondary & $\sim 15$ & & -11.9 & & 278.8 & 15.9 & $\sim 20 \% \mathrm{H} 2 \mathrm{O}$ \\
\hline CO20L-03 & $\begin{array}{l}\text { Subrounded/ } \\
\text { Rough Trail }\end{array}$ & $\begin{array}{l}\text { Pseudosec } \\
\text { ondary }\end{array}$ & $\sim 18$ & & -14.2 & & 205.7 & 18.0 & $\sim 20 \% \mathrm{H} 2 \mathrm{O}$ \\
\hline CO20L-03 & $\begin{array}{l}\text { Subrounded/ } \\
\text { Rough Trail }\end{array}$ & Secondary & $\sim 20$ & & -16.8 & & 178.4 & 20.2 & $\sim 15 \% \mathrm{H} 2 \mathrm{O}$ \\
\hline CO20L-03 & $\begin{array}{c}\text { Elongate/ Scattered } \\
\text { Trail }\end{array}$ & Secondary & $\sim 20$ & & -17.1 & & 224.3 & 20.2 & $\sim 15 \% \mathrm{H} 2 \mathrm{O}$ \\
\hline CO20L-03 & $\begin{array}{l}\text { Subrounded/ } \\
\text { Scattered Trail }\end{array}$ & Secondary & $\sim 15$ & & -16.5 & & 286.7 & 20.0 & $\sim 20 \% \mathrm{H} 2 \mathrm{O}$ \\
\hline CO20L-03 & $\begin{array}{c}\text { Subrounded/ } \\
\text { Scattered Cluster }\end{array}$ & Primary & $\sim 8$ & -58.1 & & 16.6 & & & $\sim 30 \% \mathrm{CO} 2$ \\
\hline CO20L-03 & $\begin{array}{l}\text { Subrounded/ } \\
\text { Scattered Cluster }\end{array}$ & Primary & $\sim 12$ & -58.6 & & 14.2 & & & $\sim 45 \% \mathrm{CO} 2$ \\
\hline CO20L-03 & Oval & Primary & $\sim 15$ & -58.4 & & 14.8 & & & $\sim 30 \% \mathrm{CO} 2$ \\
\hline \multicolumn{10}{|c|}{ Tuckers Knob (Qtz-Tour) } \\
\hline Sample & $\begin{array}{r}\text { Occurrence of } \\
\text { fluid inclusions }\end{array}$ & $\begin{array}{l}\text { Primary / } \\
\text { Secondary }\end{array}$ & $\begin{array}{l}\text { Size } \\
(\mu \mathrm{m})\end{array}$ & $\begin{array}{l}\mathrm{T}_{\mathrm{m}-\mathrm{CO} 2} \\
\left({ }^{\circ} \mathrm{C}\right)\end{array}$ & $\begin{array}{c}\mathrm{T}_{\mathrm{m}-\mathrm{H} 2 \mathrm{O}} \\
\left({ }^{\circ} \mathrm{C}\right)\end{array}$ & $\begin{array}{l}\mathrm{T}_{\mathrm{h}-\mathrm{CO} 2} \\
\left({ }^{\circ} \mathrm{C}\right)\end{array}$ & $\begin{array}{l}\mathrm{T}_{\mathrm{h}-\mathrm{H} 2 \mathrm{O}} \\
\left({ }^{\circ} \mathrm{C}\right)\end{array}$ & $\begin{array}{l}\mathrm{Wt} \% \\
\mathrm{NaCl}\end{array}$ & Vol \% \\
\hline $\begin{array}{l}\text { SG11- } \\
175 \mathrm{D} 2\end{array}$ & Elongate/ Trail & Secondary & $\begin{array}{c}\sim 3 \times 1 \\
5\end{array}$ & & -8.7 & & $146.7 \mathrm{D}$ & 12.1 & $\sim 80 \% \mathrm{H} 2 \mathrm{O}$ \\
\hline $\begin{array}{l}\text { SG11- } \\
175 \mathrm{D} 2\end{array}$ & Subrounded/ Trail & Secondary & $\sim 25$ & & -8.5 & & $152.3 \mathrm{D}$ & 12.2 & $\sim 80 \% \mathrm{H} 2 \mathrm{O}$ \\
\hline $\begin{array}{l}\text { SG11- } \\
175 \mathrm{D} 2\end{array}$ & $\begin{array}{c}\text { Elongate/ Rough } \\
\text { Trail }\end{array}$ & Secondary & $\sim 30$ & & -8.9 & & 154.3 & 12.7 & $\sim 20 \% \mathrm{H} 2)$ \\
\hline $\begin{array}{l}\text { SG11- } \\
175 \mathrm{D} 2\end{array}$ & $\begin{array}{c}\text { Rhombohedral/ } \\
\text { Trail }\end{array}$ & Secondary & $\sim 20$ & -57.9 & -9.6 & 25.6 & 162.8 & 13.3 & $\begin{array}{l}\sim 30 \% \mathrm{H} 2 \mathrm{O} \\
\sim 10 \% \mathrm{CO} 2\end{array}$ \\
\hline $\begin{array}{l}\text { SG11- } \\
175 \mathrm{D} 2\end{array}$ & $\begin{array}{l}\text { Subrounded/ } \\
\text { Scattered Cluster }\end{array}$ & Primary & $\sim 20$ & -56.8 & & 22.3 & & & $\sim 20 \% \mathrm{CO} 2$ \\
\hline $\begin{array}{l}\text { SG11- } \\
175 \mathrm{D} 2\end{array}$ & $\begin{array}{l}\text { Subrounded/ } \\
\text { Scattered Cluster }\end{array}$ & Primary & $\sim 15$ & & -6.5 & & 173.4 & 9.8 & $\sim 15 \% \mathrm{H} 2 \mathrm{O}$ \\
\hline $\begin{array}{l}\text { SG11- } \\
175 \mathrm{D} 2\end{array}$ & $\begin{array}{l}\text { Subrounded/ } \\
\text { Isolated Cluster }\end{array}$ & Primary & $\sim 25$ & & -8.1 & & 176.2 & 11.8 & $\sim 30 \% \mathrm{H} 2 \mathrm{O}$ \\
\hline $\begin{array}{l}\text { SG11- } \\
175 D 2\end{array}$ & $\begin{array}{l}\text { Subrounded/ } \\
\text { Isolated Cluster }\end{array}$ & Primary & $\sim 20$ & & -7.2 & & 164.8 & 10.9 & $\sim 20 \% \mathrm{H} 2 \mathrm{O}$ \\
\hline $\begin{array}{l}\text { SG11- } \\
175 \mathrm{D} 2\end{array}$ & Round/ Isolated & Primary & $\sim 20$ & -56.3 & -7.8 & 22.6 & 182.1 & 11.2 & $\begin{array}{l}\sim 20 \% \mathrm{H} 2 \mathrm{O} \\
\sim 15 \% \mathrm{CO} 2\end{array}$ \\
\hline $\begin{array}{l}\text { SG11- } \\
175 D 2\end{array}$ & $\begin{array}{l}\text { Subrounded/ } \\
\text { Isolated Cluster }\end{array}$ & Primary & $\sim 25$ & -56.2 & -6.8 & 28.7 & 157.3 & 10.2 & $\begin{array}{l}\sim 25 \% \mathrm{H} 2 \mathrm{O} \\
\sim 15 \% \mathrm{CO} 2\end{array}$ \\
\hline $\begin{array}{l}\text { SG11- } \\
175 \mathrm{D} 2\end{array}$ & $\begin{array}{c}\text { Elongate/ Scattered } \\
\text { Cluster }\end{array}$ & Primary & $\sim 30$ & -56.4 & -6.6 & 29.0 & 206.1 & 9.9 & $\begin{array}{l}\sim 20 \% \mathrm{H} 2 \mathrm{O} \\
\sim 15 \% \mathrm{CO} 2\end{array}$ \\
\hline $\begin{array}{l}\text { SG11- } \\
175 \mathrm{D} 2\end{array}$ & $\begin{array}{c}\text { Subrounded/ } \\
\text { Scattered Cluster }\end{array}$ & Primary & $\sim 15$ & -56.9 & & 23.3 & & & $\sim 25 \% \mathrm{CO} 2$ \\
\hline
\end{tabular}




\section{Appendix E}

Gas Bench Mass Spectrometer Stable Isotope Data 
Table E1 - Gas Source Mass Spectrometer analysis of carbonate from the East Bay Trend, Red Lake, Ontario

\begin{tabular}{|c|c|c|c|c|c|c|}
\hline Lab ID & Sample Name & $\begin{array}{c}\delta^{13} \mathrm{C} \\
(\mathrm{PDB})\end{array}$ & $\begin{array}{c}\delta^{18} \mathbf{O} \\
(\mathrm{VSMOW})\end{array}$ & $2 \sigma$ & $\begin{array}{l}\text { Sample wt. } \\
\text { used }\end{array}$ & $\begin{array}{c}\text { Property/ } \\
\text { Deposit }\end{array}$ \\
\hline C-62589 & MB894 & 2.50 & 17.86 & 0.1 & 0.543 & Marboy \\
\hline C- 62590 & MB10034 & 1.82 & 15.26 & 0.1 & 0.592 & Marboy \\
\hline C-62591 & MB10034 & 1.35 & 16.35 & 0.1 & 0.639 & Marboy \\
\hline C- 62592 & MB10035 & 0.98 & 15.24 & 0.1 & 0.561 & Marboy \\
\hline C-62593 & EB90-03 & -1.72 & 13.54 & 0.1 & 0.582 & Chevron \\
\hline C-62594 & EB90-03 & -0.97 & 13.59 & 0.1 & 0.539 & Chevron \\
\hline C-62595 & EB90-12 & -2.07 & 13.29 & 0.1 & 0.544 & Chevron \\
\hline C-62596 & EB90-12 DUP & -2.05 & 13.61 & 0.1 & 0.541 & Chevron \\
\hline C-62597 & ABU-34 & 1.07 & 13.71 & 0.1 & 0.582 & Abino \\
\hline C-62598 & EB09031 & -1.63 & 13.13 & 0.1 & 0.614 & Duchesne \\
\hline C-62599 & SG11-046 & 2.65 & 16.32 & 0.1 & 0.521 & Marboy \\
\hline C- 62600 & SG11-050B & 0.44 & 14.98 & 0.1 & 0.562 & Tuckers Knob \\
\hline C-62601 & SG11-060 & -0.16 & 11.12 & 0.1 & 0.527 & Marboy \\
\hline C- 62602 & SG11-115 & 1.23 & 12.96 & 0.1 & 0.547 & Redcon \\
\hline C- 62603 & SG11-171A & 3.74 & 16.18 & 0.1 & 0.616 & Tuckers Knob \\
\hline C- 62604 & SG11-174B & 0.06 & 14.58 & 0.1 & 0.604 & Tuckers Knob \\
\hline C- 62605 & SG11-175E & 1.96 & 14.68 & 0.1 & 0.542 & Tuckers Knob \\
\hline C-62606 & SG11-175E & 2.11 & 15.34 & 0.1 & 0.591 & Tuckers Knob \\
\hline C- 62607 & SG11-175J & 3.33 & 17.17 & 0.1 & 0.557 & Tuckers Knob \\
\hline C- -62608 & SG11-176B & 0.76 & 13.74 & 0.1 & 0.559 & Tuckers Knob \\
\hline C-62609 & SG11-176C & 1.54 & 14.34 & 0.1 & 0.564 & Tuckers Knob \\
\hline C- 62610 & SG11-176C DUP & 1.53 & 14.34 & 0.1 & 0.559 & McFinley \\
\hline C-62611 & SG11-177A & 1.97 & 17.05 & 0.1 & 0.599 & Abino \\
\hline C- 62612 & $\begin{array}{l}\text { SG11-177A (Light } \\
\text { CRB vein) }\end{array}$ & 1.53 & 15.82 & 0.1 & 0.523 & Abino \\
\hline C- 62613 & SG11-177B & 1.42 & 14.94 & 0.1 & 0.641 & Abino \\
\hline C- 62614 & SG11-177C & 0.91 & 16.15 & 0.1 & 0.558 & Abino \\
\hline
\end{tabular}

Blind Standard C-44:

$\delta^{13} \mathrm{C}(\mathrm{PDB})=-1.77, \mathrm{n}=2$, st.dev. $=0.08$

$\delta^{18} 0($ VSMOW $)=8.96, n=2$, st.dev. $=0.09$

Note: data for C and $\mathrm{O}$ were normalized using international standards NBS-18, NBS-19, and LSVEC (C only). 
Appendix F

Secondary Ion Mass Spectrometer Data 
Table F1 - Secondary ion mass spectrometer analyses of quartz veins from the East Bay Trend, Red Lake, Ontario

\begin{tabular}{lccccc}
\hline Sample Number & Sample Name & ${ }^{\mathbf{1 8}} \mathbf{O} /{ }^{\mathbf{1 6}} \mathbf{O}_{\text {meas }}$ & Mass Bias & $\mathbf{1 \sigma}$ & $\boldsymbol{\delta}^{\mathbf{1 8}} \mathbf{O}$ VSMOW (\%o) \\
\hline 7-120-std-sp4 & UWQ std & 1.865472 & 0.9190 & 1.2 & -81.0 \\
7-120-std-sp6 & UWQ std & 1.863534 & 0.9180 & 1.2 & -82.0 \\
$7-120$-std-sp7 & UWQ std & 1.860683 & 0.9166 & 1.2 & -83.4 \\
7-120-std-sp9 & UWQ std & 1.858866 & 0.9157 & 1.2 & -84.3 \\
& & & & \\
Average & & 1.8621 & 0.9174 & & -82.6 \\
Standard Deviation & 0.0025 & & & 1.3 \\
Instrumental Mass Fractionation & & & & 1.8395 \\
\hline
\end{tabular}

True VSMOW $18 \mathrm{O} / 16 \mathrm{O}$ value $=2.0052$

True UWQ quartz value $=2.0299$

\begin{tabular}{ccccc}
\hline Sample Number & Sample Name & ${ }^{\mathbf{1 8}} \mathbf{O} /{ }^{\mathbf{1 6}} \mathbf{O}_{\text {meas }}$ & $\mathbf{1 \sigma}$ & $\boldsymbol{\delta}^{\mathbf{1 8}} \mathbf{O}$ VSMOW (\%o) \\
\hline $7-12011$ & EB9017-02-1 & 1.850053 & 1.2 & 5.7 \\
$7-12012$ & EB9017-02-2 & 1.849052 & 1.2 & 5.2 \\
$7-12013$ & EB9017-02-3 & 1.850625 & 1.2 & 6.1 \\
$7-12014$ & EB9017-02-4 & 1.842202 & 1.2 & 1.5 \\
$7-12015$ & EB9017-02-5 & 1.845016 & 1.2 & 3.0 \\
$7-12016$ & EB9017-02-6 & 1.84744 & 1.2 & 4.3 \\
$7-12026$ & EB10048-2-1 & 1.856445 & 1.2 & 9.2 \\
$7-12027$ & EB10048-2-2 & 1.86136 & 1.2 & 11.9 \\
$7-12028$ & EB10048-2-3 & 1.854984 & 1.2 & 8.4 \\
$7-12029$ & EB10048-2-4 & 1.853466 & 1.2 & 7.6 \\
$7-12030$ & EB10048-2-5 & 1.855241 & 1.2 & 8.6 \\
$7-12031$ & ABU86-49-1 & 1.849299 & 1.2 & 5.3 \\
$7-12032$ & ABU86-49-2 & 1.846432 & 1.2 & 3.8 \\
$7-12033$ & ABU86-49-3 & 1.854862 & 1.2 & 8.4 \\
$7-12034$ & ABU86-49-4 & 1.845316 & 1.2 & 3.2 \\
$7-12035$ & ABU86-49-5 & 1.838859 & 1.2 & -0.3 \\
\hline
\end{tabular}


Table F1 Continued

\begin{tabular}{|c|c|c|c|c|c|}
\hline Sample Number & Sample Name & ${ }^{18} \mathrm{O} /{ }^{16} \mathrm{O}_{\text {meas }}$ & Mass Bias & $1 \sigma$ & $\delta^{18}$ O VSMOW (\%o) \\
\hline $7-1304$ & UWQ std & 1.851728 & 0.9122 & 1.2 & -87.8 \\
\hline $7-1306$ & UWQ std & 1.850977 & 0.9119 & 1.2 & -88.1 \\
\hline $7-1307$ & UWQ std & 1.847188 & 0.9100 & 1.2 & -90.0 \\
\hline $7-1308$ & UWQ std & 1.847446 & 0.9101 & 1.2 & -89.9 \\
\hline $7-1309$ & UWQ std & 1.844507 & 0.9087 & 1.2 & -91.3 \\
\hline \multicolumn{2}{|l|}{ Average } & 1.8484 & 0.9106 & & -89.4 \\
\hline \multicolumn{2}{|c|}{ Standard Deviation } & 0.0027 & & & 1.3 \\
\hline \multicolumn{5}{|c|}{ Instrumental Mass Fractionation } & 1.8395 \\
\hline
\end{tabular}

True VSMOW 180/160 value $=2.0052$

True UWQ quartz value $=2.0299$

\begin{tabular}{|c|c|c|c|c|}
\hline Sample Number & Sample Name & ${ }^{18} \mathrm{O} /{ }^{16} \mathrm{O}_{\text {meas }}$ & $1 \sigma$ & $\delta^{18}$ O VSMOW (\%o) \\
\hline 7-13o10 & ABU-51-1-1 & 1.838082 & 1.2 & 6.7 \\
\hline $7-13011$ & ABU-51-1-2 & 1.836256 & 1.2 & 5.7 \\
\hline 7-13o12 & ABU-51-1-3 & 1.842111 & 1.2 & 8.9 \\
\hline 7-13o13 & ABU-51-1-4 & 1.842558 & 1.2 & 9.1 \\
\hline 7-13o14 & ABU-51-1-5 & 1.841808 & 1.2 & 8.7 \\
\hline $7-12017$ & EB9017-1-1 & 1.843689 & 1.2 & 9.8 \\
\hline 7-13o15 & ЕВ9017-1-2 & 1.847772 & 1.2 & 12.0 \\
\hline 7-13o16 & EB9017-1-3 & 1.841475 & 1.2 & 8.5 \\
\hline 7-13o17 & ЕВ9017-1-4 & 1.845260 & 1.2 & 10.6 \\
\hline 7-13o18 & EB9017-1-5 & 1.843465 & 1.2 & 9.6 \\
\hline 7-13o19 & EB9017-1-6 & 1.838875 & 1.2 & 7.1 \\
\hline $7-12020$ & SG11-175D2-1 & 1.803329 & 1.2 & -12.3 \\
\hline $7-12021$ & SG11-175D2-2 & 1.837362 & 1.2 & 6.3 \\
\hline $7-12022$ & SG11-175D2-3 & 1.823018 & 1.2 & -1.6 \\
\hline $7-12023$ & SG11-175D2-4 & 1.828598 & 1.2 & 1.5 \\
\hline $7-12024$ & SG11-175D2-5 & 1.832453 & 1.2 & 3.6 \\
\hline $7-12025$ & SG11-175D2-6 & 1.839404 & 1.2 & 7.4 \\
\hline
\end{tabular}


Table F1 Continued

\begin{tabular}{|c|c|c|c|c|c|}
\hline Sample Number & Sample Name & ${ }^{18} \mathrm{O} /{ }^{16} \mathrm{O}_{\text {meas }}$ & Mass Bias & $1 \sigma$ & $\delta^{18}$ O VSMOW (\%o) \\
\hline $7-1604$ & UWQ std & 1.843080 & 0.9080 & 1.2 & -92.0 \\
\hline 7-16o6 & UWQ std & 1.843634 & 0.9082 & 1.2 & -91.8 \\
\hline $7-1607$ & UWQ std & 1.838376 & 0.9056 & 1.2 & -94.4 \\
\hline $7-1608$ & UWQ std & 1.843092 & 0.9080 & 1.2 & -92.0 \\
\hline \multicolumn{2}{|l|}{ Average } & 1.8420 & 0.9075 & & -92.5 \\
\hline \multicolumn{2}{|c|}{ Standard Deviation } & 0.0021 & & & 1.0 \\
\hline \multicolumn{5}{|c|}{ Instrumental Mass Fractionation } & 1.8395 \\
\hline
\end{tabular}

True VSMOW 18O/160 value $=2.0052$

True UWQ quartz value $=2.0299$

\begin{tabular}{|c|c|c|c|c|}
\hline Sample Number & Sample Name & ${ }^{18} \mathrm{O} /{ }^{16} \mathrm{O}_{\text {meas }}$ & $1 \sigma$ & $\delta^{18}$ O VSMOW (\%o) \\
\hline $7-1609$ & MB891-06-1 & 1.838020 & 1.2 & 10.1 \\
\hline $7-16010$ & MB891-06-2 & 1.840652 & 1.2 & 11.6 \\
\hline $7-16011$ & MB891-06-3 & 1.841046 & 1.2 & 11.8 \\
\hline $7-16012$ & MB891-06-4 & 1.843943 & 1.2 & 13.4 \\
\hline $7-16013$ & MB891-06-5 & 1.833832 & 1.2 & 7.8 \\
\hline $7-16014$ & MB891-06-6 & 1.840364 & 1.2 & 11.4 \\
\hline $7-16015$ & MB10034-03-1 & 1.830676 & 1.2 & 6.1 \\
\hline 7-16o16 & MB10034-03-2 & 1.822294 & 1.2 & 1.5 \\
\hline $7-16017$ & MB10034-03-3 & 1.817885 & 1.2 & -1.0 \\
\hline $7-16018$ & MB10034-03-4 & 1.818602 & 1.2 & -0.6 \\
\hline 7-16o19 & SG11-171D-1 & 1.875153 & 1.2 & 30.5 \\
\hline $7-16020$ & SG11-171D-2 & 1.829960 & 1.2 & 5.7 \\
\hline $7-16021$ & SG11-171D-3 & 1.829628 & 1.2 & 5.5 \\
\hline $7-16022$ & SG11-171D-4 & 1.828550 & 1.2 & 4.9 \\
\hline $7-16023$ & SG11-171D-5 & 1.828681 & 1.2 & 5.0 \\
\hline $7-16024$ & SG11-171D-6 & 1.824006 & 1.2 & 2.4 \\
\hline
\end{tabular}


Table F1 Continued

\begin{tabular}{|c|c|c|c|c|c|}
\hline Sample Number & Sample Name & ${ }^{18} \mathrm{O} /{ }^{16} \mathrm{O}_{\text {meas }}$ & Mass Bias & $1 \sigma$ & $\delta^{18}$ O VSMOW (\%o) \\
\hline 7-17o1 & UWQ std & 1.812081 & 0.8927 & 1.2 & -107.3 \\
\hline $7-17 \mathrm{o} 2$ & UWQ std & 1.808656 & 0.8910 & 1.2 & -109.0 \\
\hline $7-17$ o3 & UWQ std & 1.807844 & 0.8906 & 1.2 & -109.4 \\
\hline $7-17 o 4$ & UWQ std & 1.811302 & 0.8923 & 1.2 & -107.7 \\
\hline $7-17$ o5 & UWQ std & 1.813094 & 0.8932 & 1.2 & -106.8 \\
\hline \multicolumn{2}{|l|}{ Average } & 1.8106 & 0.8920 & & -108.0 \\
\hline \multicolumn{2}{|c|}{ Standard Deviation } & 0.0020 & & & 1.0 \\
\hline \multicolumn{5}{|c|}{ Instrumental Mass Fractionation } & 1.8395 \\
\hline
\end{tabular}

True VSMOW 180/160 value $=2.0052$

True UWQ quartz value $=2.0299$

\begin{tabular}{ccccc}
\hline Sample Number & Sample Name & ${ }^{\mathbf{1 8}} \mathbf{O} /{ }^{\mathbf{1 6}} \mathbf{O}_{\text {meas }}$ & $\mathbf{1 \sigma}$ & $\boldsymbol{\delta}^{\mathbf{1 8}}$ O VSMOW (\%o) \\
\hline $7-1706$ & EB10048-03-1 & 1.805142 & 1.2 & 9.3 \\
$7-1707$ & EB10048-03-2 & 1.811126 & 1.2 & 12.6 \\
$7-1708$ & EB10048-03-3 & 1.808330 & 1.2 & 11.1 \\
$7-1709$ & EB10048-03-4 & 1.810389 & 1.2 & 12.2 \\
$7-17$ o10 & EB10048-03-5 & 1.808878 & 1.2 & 11.4 \\
$7-17011$ & CO20L-03-1 & 1.807742 & 1.2 & 10.7 \\
$7-17$ o12 & CO20L-03-2 & 1.813346 & 1.2 & 13.9 \\
$7-17013$ & CO20L-03-3 & 1.811664 & 1.2 & 12.9 \\
$7-17$ o14 & CO20L-03-4 & 1.811498 & 1.2 & 12.8 \\
$7-17015$ & CO20L-03-5 & 1.811491 & 1.2 & 12.8 \\
\hline
\end{tabular}


Table F2 - Secondary ion mass spectrometer analyses of pyrite from the East Bay Trend, Red Lake, Ontario

\begin{tabular}{ccccc}
\hline Sample Number & Sample Name & ${ }^{\mathbf{3 4}} \mathbf{S} /{ }^{\mathbf{3 2}} \mathbf{S}_{\text {meas }}$ & $\mathbf{1 \sigma}$ & Mass Bias \\
\hline 4-13s-std-sp8 & Balmat Py Std & 4.267369 & 0.3 & -65.9 \\
4-13s-std-sp9 & Balmat Py Std & 4.264867 & 0.3 & -66.4 \\
4-13s-std-sp10 & Balmat Py Std & 4.264784 & 0.3 & -66.5 \\
4 -13s-std-sp11 & Balmat Py Std & 4.265839 & 0.3 & -66.2 \\
4 -13s-std-sp12 & Balmat Py Std & 4.263641 & 0.3 & -66.7 \\
4 -13s-std-sp40 & Balmat Py Std & 4.263641 & 0.3 & -66.7 \\
Average & & & & -66.41 \\
Standard Deviation & & 4.265024 & & 0.3 \\
Instrumental Mass Fractionation & & & 4.201586 \\
\hline
\end{tabular}

True CDT 34S $/ 32$ S value $=4.50045$

True Balmat pyrite value $=4.5684$

\begin{tabular}{|c|c|c|c|c|c|}
\hline Sample Number & Sample Name & ${ }^{\mathbf{3 4}} \mathbf{S} /{ }^{32} \mathbf{S}_{\text {meas }}$ & $\mathbf{1 \sigma}$ & $\boldsymbol{\delta}^{\mathbf{3 4}} \mathbf{S} \mathbf{C D T}(\mathbf{\% o})$ & $\mathbf{2 \sigma}$ (totl) \\
\hline 4-13s-sp13 & MB891-05-1 & 4.220945 & 0.3 & 4.5 & 0.4 \\
4-13s-sp14 & MB891-05-2 & 4.224988 & 0.3 & 5.5 & 0.4 \\
4-13s-sp15 & MB891-05-3 & 4.220895 & 0.3 & 4.5 & 0.4 \\
4-13s-sp16 & MB891-05-4 & 4.216574 & 0.3 & 3.5 & 0.4 \\
4-13s-sp17 & MB891-05-5 & 4.211105 & 0.3 & 2.2 & 0.4 \\
4-13s-sp18 & MB891-05-6 & 4.213667 & 0.3 & 2.8 & 0.4 \\
4-13s-sp19 & MB891-05-7 & 4.210185 & 0.3 & 2.0 & 0.4 \\
4-13s-sp20 & MB891-05-8 & 4.213311 & 0.3 & 2.7 & 0.4 \\
4-13s-sp21 & MB10034-2-1 & 4.220928 & 0.3 & 4.5 & 0.4 \\
4-13s-sp22 & MB10034-2-2 & 4.233424 & 0.3 & 7.5 & 0.4 \\
$4-13 s-s p 23$ & MB10034-2-3 & 4.217476 & 0.3 & 3.7 & 0.4 \\
4-13s-sp24 & MB10034-2-4 & 4.220510 & 0.3 & 4.4 & 0.4 \\
4-13s-sp25 & MB10034-2-5 & 4.225717 & 0.3 & 5.7 & 0.4 \\
4-13s-sp26 & MB10034-2-6 & 4.221732 & 0.3 & 4.7 & 0.4 \\
4-13s-sp27 & MB10034-2-7 & 4.220960 & 0.3 & 4.5 & 0.4 \\
\hline
\end{tabular}


Table F2 Continued

\begin{tabular}{|c|c|c|c|c|c|}
\hline Sample Number & Sample Name & ${ }^{34} \mathrm{~S} /{ }^{32} \mathrm{~S}_{\text {meas }}$ & $1 \sigma$ & $\delta^{34} \mathrm{~S}$ CDT (\%o) & $2 \sigma$ (totl) \\
\hline $4-13 s-s p 28$ & ABU51-02-1 & 4.213577 & 0.3 & 2.8 & 0.4 \\
\hline $4-13 s-s p 29$ & ABU51-02-2 & 4.223445 & 0.3 & 5.1 & 0.4 \\
\hline $4-13 s-s p 30$ & ABU51-02-3 & 4.233365 & 0.3 & 7.5 & 0.4 \\
\hline $4-13 s-s p 31$ & ABU51-02-4 & 4.216786 & 0.3 & 3.6 & 0.4 \\
\hline 4-13s-sp32 & ABU51-02-5 & 4.222400 & 0.3 & 4.9 & 0.4 \\
\hline $4-13 s-s p 33$ & ABU51-02-6 & 4.210767 & 0.3 & 2.1 & 0.4 \\
\hline 4-13s-sp34 & ABU51-02-7 & 4.237462 & 0.3 & 8.5 & 0.4 \\
\hline 4-13s-sp35 & ABU51-01-1 & 4.251251 & 0.3 & 11.8 & 0.4 \\
\hline 4-13s-sp36 & ABU51-01-2 & 4.220713 & 0.3 & 4.5 & 0.4 \\
\hline $4-13 s-s p 37$ & ABU51-01-3 & 4.217769 & 0.3 & 3.8 & 0.4 \\
\hline 4-13s-sp38 & ABU51-01-4 & 4.204105 & 0.3 & 0.5 & 0.4 \\
\hline $4-13 s-s p 39$ & ABU51-01-5 & 4.226210 & 0.3 & 5.8 & 0.4 \\
\hline
\end{tabular}


Table F2 Continued - Second Analytical Session

\begin{tabular}{ccccc}
\hline Sample Number & Sample Name & ${ }^{\mathbf{3 4}} \mathbf{S} /{ }^{\mathbf{3 2}} \mathbf{S}_{\text {meas }}$ & $\mathbf{1 \sigma}$ & Mass Bias \\
\hline 7-17s-std-sp1 & Balmat Py Std & 4.228524 & 0.3 & -74.4 \\
$7-17 s-s t d-s p 2$ & Balmat Py Std & 4.228038 & 0.3 & -74.5 \\
$7-17 s-s t d-s p 3$ & Balmat Py Std & 4.223874 & 0.3 & -75.4 \\
$7-17 s-s t d-s p 4$ & Balmat Py Std & 4.227192 & 0.3 & -74.7 \\
$7-17 s-s t d-s p 5$ & Balmat Py Std & 4.219495 & 0.3 & -76.4 \\
& & & & -75.08 \\
Average & & 4.225425 & & 0.8 \\
Standard Deviation & 0.003779 & & 4.1626 \\
Instrumental Mass Fractionation & & & \\
\hline
\end{tabular}

True CDT 34S $/ 32$ S value $=4.50045$

True Balmat pyrite value $=4.5684$

\begin{tabular}{|c|c|c|c|c|c|}
\hline Sample Number & Sample Name & ${ }^{34} \mathrm{~S} /{ }^{32} \mathrm{~S}_{\text {meas }}$ & $1 \sigma$ & $\delta^{34}$ S CDT (\%o) & $2 \sigma$ (totl) \\
\hline $7-17 \mathrm{~s}-\mathrm{sp} 7$ & EB903-01-1 & 4.180900 & 0.3 & 4.4 & 0.9 \\
\hline $7-17 \mathrm{~s}-\mathrm{sp} 8$ & EB903-01-2 & 4.188848 & 0.3 & 6.3 & 0.9 \\
\hline $7-17 \mathrm{~s}-\mathrm{sp} 9$ & EB903-01-3 & 4.188741 & 0.3 & 6.3 & 0.9 \\
\hline $7-17 s-s p 10$ & EB903-01-4 & 4.185469 & 0.3 & 5.5 & 0.9 \\
\hline 7-17s-sp11 & EB903-01-5 & 4.187572 & 0.3 & 6.0 & 0.9 \\
\hline 7-17s-sp12 & EB9017-01-1 & 4.185102 & 0.3 & 5.4 & 0.9 \\
\hline $7-17 s-s p 13$ & EB9017-01-2 & 4.175080 & 0.3 & 3.0 & 0.9 \\
\hline $7-17 s-s p 14$ & EB9017-01-3 & 4.170403 & 0.3 & 1.9 & 0.9 \\
\hline $7-17 s-s p 15$ & EB9017-01-4 & 4.182497 & 0.3 & 4.8 & 0.9 \\
\hline $7-17 s-s p 16$ & EB9017-01-5 & 4.180240 & 0.3 & 4.2 & 0.9 \\
\hline $7-17 s-s p 17$ & EB9017-01-6 & 4.163614 & 0.3 & 0.2 & 0.9 \\
\hline $7-17 s-s p 18$ & SG11-171C-1 & 4.174204 & 0.3 & 2.8 & 0.9 \\
\hline $7-17 \mathrm{~s}-\mathrm{sp} 19$ & SG11-171C-2 & 4.170705 & 0.3 & 2.0 & 0.9 \\
\hline $7-17 s-s p 20$ & SG11-171C-3 & 4.174355 & 0.3 & 2.8 & 0.9 \\
\hline $7-17 s-s p 21$ & SG11-171C-4 & 4.188906 & 0.3 & 6.3 & 0.9 \\
\hline
\end{tabular}


Table F3 - Secondary ion mass spectrometer analyses of quartz within quartztourmaline vein SG11-174B from the East Bay Trend, Red Lake, Ontario

\begin{tabular}{cccccc}
\hline Sample Number & Sample Name & ${ }^{\mathbf{1 8}} \mathbf{O} /{ }^{16} \mathbf{O}_{\text {meas }}$ & Mass Bias & $\mathbf{1 \sigma}$ & $\boldsymbol{\delta}^{\mathbf{1 8}} \mathbf{O}$ VSMOW (\%o) \\
\hline 4-3o-std-sp6 & UWQ Qtz std & 1.860726 & 0.9167 & 1.2 & -83.3 \\
4-3o-std-sp7 & UWQ Qtz std & 1.854366 & 0.9135 & 1.2 & -86.5 \\
4-3o-std-sp8 & UWQ Qtz std & 1.858393 & 0.9155 & 1.2 & -84.5 \\
4-30-std-sp10 & UWQ Qtz std & 1.860984 & 0.9168 & 1.2 & -83.2 \\
4-30-std-sp11 & UWQ Qtz std & 1.858564 & 0.9156 & 1.2 & -84.4 \\
& & & & \\
Average & & 1.8586 & 0.9156 & & -84.4 \\
Standard Deviation & 0.0024 & & & 1.2 \\
Instrumental Mass Fractionation & & & & 1.8360 \\
\hline
\end{tabular}

True VSMOW $18 \mathrm{O} / 16 \mathrm{O}$ value $=2.0052$

True UWQ quartz value $=2.0299$

\begin{tabular}{ccccc}
\hline Sample Number & Sample Name & ${ }^{\mathbf{1 8}} \mathbf{O} /{ }^{\mathbf{1 6}} \mathbf{O}_{\text {meas }}$ & $\mathbf{1 \sigma}$ & $\boldsymbol{\delta}^{\mathbf{1 8}} \mathbf{O}$ VSMOW (\%o) \\
\hline 4-30-sp12 & SG11-174B & 1.863946 & 1.2 & 15.2 \\
4 4-30-sp13 & SG11-174B & 1.869075 & 1.2 & 18.0 \\
4 4-30-sp15 & SG11-174B & 1.869668 & 1.2 & 18.3 \\
4-30-sp16 & SG11-174B & 1.868288 & 1.2 & 17.6 \\
& & & & \\
Average & & 1.8677 & & 17.3 \\
Standard Deviation & & 0.0041 & & 1.2 \\
\hline
\end{tabular}


Table F4 - Secondary ion mass spectrometer analyses of quartz within quartztourmaline vein SG11-177B from the East Bay Trend, Red Lake, Ontario

\begin{tabular}{cccccc}
\hline Sample Number & Sample Name & ${ }^{\mathbf{1 8}} \mathbf{O} /{ }^{\mathbf{1 6}} \mathbf{O}_{\text {meas }}$ & Mass Bias & $\mathbf{1 \sigma}$ & $\boldsymbol{\delta}^{\mathbf{1 8}} \mathbf{O}$ VSMOW (\%o) \\
\hline 4-3o-std-sp31 & UWQ Qtz std & 1.867730 & 0.9201 & 1.2 & -79.9 \\
4-3o-std-sp32 & UWQ Qtz std & 1.867062 & 0.9198 & 1.2 & -80.2 \\
4-3o-std-sp33 & UWQ Qtz std & 1.870010 & 0.9212 & 1.2 & -78.8 \\
4-3o-std-sp35 & UWQ Qtz std & 1.868450 & 0.9205 & 1.2 & -79.5 \\
4-3o-std-sp36 & UWQ Qtz std & 1.866475 & 0.9195 & 1.2 & -80.5 \\
4-3o-std-sp37 & UWQ Qtz std & 1.867095 & 0.9198 & 1.2 & -80.2 \\
& & & & & \\
Average & & 1.8678 & 0.9201 & & -79.9 \\
Standard Deviation & & 0.0011 & & & 0.6 \\
Instrumental Mass Fractionation & & & & 1.8360 \\
\hline
\end{tabular}

True VSMOW $18 \mathrm{O} / 16 \mathrm{O}$ value $=2.0052$

True UWQ quartz value $=2.0299$

\begin{tabular}{ccccc}
\hline Sample Number & Sample Name & ${ }^{\mathbf{1 8}} \mathbf{O} /{ }^{\mathbf{1 6}} \mathbf{O}_{\text {meas }}$ & $\mathbf{1 \sigma}$ & $\boldsymbol{\delta}^{\mathbf{1 8}} \mathbf{O}$ VSMOW (\%o) \\
\hline 4-30-sp21 & SG11-177B & 1.876458 & 1.3 & 17.0 \\
4-3o-sp23 & SG11-177B & 1.875321 & 1.2 & 16.4 \\
4-30-sp25 & SG11-177B & 1.878785 & 1.2 & 18.3 \\
4-30-sp26 & SG11-177B & 1.876535 & 1.2 & 17.1 \\
4-3o-sp29 & SG11-177B & 1.876359 & 1.2 & 17.0 \\
4-3o-sp30 & SG11-177B & 1.877732 & 1.2 & 17.7 \\
& & & & \\
Average & & 1.8769 & & 17.2 \\
Standard Deviation & & 0.0011 & & 0.6 \\
\hline
\end{tabular}


Table F5 - Secondary ion mass spectrometer analyses of tourmaline within quartztourmaline veins SG11-177B from the East Bay Trend, Red Lake, Ontario

\begin{tabular}{ccccc}
\hline Sample Number & Sample Name & ${ }^{\mathbf{1 8}} \mathbf{O} /{ }^{\mathbf{1 6}} \mathbf{O}_{\text {meas }}$ & $\mathbf{1 \sigma}$ & $\boldsymbol{\delta}^{\mathbf{1 8}} \mathbf{O}$ VSMOW (\%o) \\
\hline 4-2o-std-sp10 & 98144 Elbaite & 1.915320 & 1.2 & -57.9 \\
4-2o-std-sp11 & 98144 Elbaite & 1.912587 & 1.2 & -59.3 \\
4-2o-std-sp12 & 98144 Elbaite & 1.910829 & 1.2 & -60.1 \\
4-2o-std-sp13 & 98144 Elbaite & 1.912941 & 1.2 & -59.1 \\
4-2o-std-sp14 & 98144 Elbaite & 1.911901 & 1.2 & -59.6 \\
& & & & -59.2 \\
Average & & 1.9127 & & 0.8 \\
Standard Deviation & 0.0017 & & 1.8865 \\
Instrumental Mass Fractionation & & & \\
\hline
\end{tabular}

True VSMOW $18 \mathrm{O} / 16 \mathrm{O}$ value $=2.0052$

True 98144 Elbaite value $=2.0331$

\begin{tabular}{ccccc}
\hline Sample Number & Sample Name & ${ }^{\mathbf{1 8}} \mathbf{O} /{ }^{\mathbf{1 6}} \mathbf{O}_{\text {meas }}$ & $\mathbf{1 \sigma}$ & $\boldsymbol{\delta}^{\mathbf{1 8}} \mathbf{O}$ VSMOW (\%o) \\
\hline 4-2o-sp12 & SG11-177B & 1.876458 & 1.2 & 11.0 \\
4-2o-sp13 & SG11-177B & 1.875321 & 1.2 & 7.8 \\
4-2o-sp14 & SG11-177B & 1.878785 & 1.2 & 10.8 \\
4-2o-sp16 & SG11-177B & 1.876535 & 1.2 & 8.9 \\
& & & & \\
Average & & 1.9046 & & 9.6 \\
Standard Deviation & 0.0028 & & 1.5 \\
\hline
\end{tabular}


Table F6 - Secondary ion mass spectrometer analyses of tourmaline within quartztourmaline veins SG11-174B from the East Bay Trend, Red Lake, Ontario

\begin{tabular}{ccccc}
\hline Sample Number & Sample Name & ${ }^{\mathbf{1 8}} \mathbf{O} /{ }^{\mathbf{1 6}} \mathbf{O}_{\text {meas }}$ & $\mathbf{1 \sigma}$ & $\boldsymbol{\delta}^{\mathbf{1 8}} \mathbf{O}$ VSMOW (\%o) \\
\hline 4-2o-std-sp24 & 108796 Dravite & 1.850755 & 1.2 & -86.5 \\
4-2o-std-sp25 & 108796 Dravite & 1.845694 & 1.2 & -89.0 \\
4-2o-std-sp26 & 108796 Dravite & 1.846749 & 1.2 & -88.4 \\
4-2o-std-sp28 & 108796 Dravite & 1.849705 & 1.2 & -87.0 \\
4-2o-std-sp29 & 108796 Dravite & 1.853768 & 1.2 & -85.0 \\
& & & & -87.2 \\
Average & & 1.8493 & & 1.6 \\
Standard Deviation & 0.0032 & & 1.830438 \\
Instrumental Mass Fractionation & & & \\
\hline
\end{tabular}

True VSMOW $18 \mathrm{O} / 16 \mathrm{O}$ value $=2.0052$

True 108796 Dravite value $=2.0259$

\begin{tabular}{ccccc}
\hline Sample Number & Sample Name & ${ }^{\mathbf{1 8}} \mathbf{O} /{ }^{\mathbf{1 6}} \mathbf{O}_{\text {meas }}$ & $\mathbf{1 \sigma}$ & $\boldsymbol{\delta}^{\mathbf{1 8}} \mathbf{O}$ VSMOW (\%o) \\
\hline 4-2o-sp12 & SG11-174B & 1.847814 & 1.2 & 9.5 \\
4-2o-sp13 & SG11-174B & 1.845251 & 1.2 & 8.1 \\
4-2o-sp14 & SG11-174B & 1.847063 & 1.2 & 9.1 \\
4-2o-sp16 & SG11-174B & 1.84959 & 1.2 & 10.5 \\
& & & & \\
Average & & 1.8474 & & 9.3 \\
Standard Deviation & 0.0018 & & 1.0 \\
\hline
\end{tabular}


Table F7 - Oxygen isotope values from quartz vein samples

Marboy barren sample $\delta^{18} 0$ isotopic values

\begin{tabular}{ccccc}
\hline Sample Number & Sample Name & ${ }^{\mathbf{1 8}} \mathbf{O} /{ }^{\mathbf{1 6}} \mathbf{O}_{\text {meas }}$ & $\mathbf{1 \sigma}$ & $\boldsymbol{\delta}^{\mathbf{1 8}} \mathbf{O}_{\text {vSMOW }}(\%)$ \\
\hline $7-16016$ & MB10034-03-2 & 1.822294 & 1.2 & 1.5 \\
$7-16017$ & MB10034-03-3 & 1.817885 & 1.2 & -1.0 \\
$7-16018$ & MB10034-03-4 & 1.818602 & 1.2 & -0.6
\end{tabular}

\begin{tabular}{lll} 
Average & 1.8196 & $\mathbf{0 . 0}$ \\
Standard Deviation & 0.0019 & $\mathbf{1 . 1}$ \\
\hline
\end{tabular}

\begin{tabular}{lrrrr}
\hline \multicolumn{5}{c}{ Marboy auriferous sample $\delta^{18}$ O isotopic values } \\
\hline 7-1609 & MB891-06-1 & 1.838020 & 1.2 & 10.1 \\
$7-16010$ & MB891-06-2 & 1.840652 & 1.2 & 11.6 \\
$7-16011$ & MB891-06-3 & 1.841046 & 1.2 & 11.8 \\
$7-16014$ & MB891-06-6 & 1.840364 & 1.2 & 11.4 \\
& & & & \\
Average & & 1.8400 & & $\mathbf{1 1 . 2}$ \\
Standard Deviation & & 0.0012 & & $\mathbf{0 . 6}$ \\
\hline
\end{tabular}

\begin{tabular}{|c|c|c|c|c|}
\hline \multicolumn{5}{|c|}{ Chevron barren sample $\delta^{18} 0$ isotopic values } \\
\hline $7-12011$ & EB9017-02-1 & 1.850053 & 1.2 & 5.7 \\
\hline $7-12012$ & EB9017-02-2 & 1.849052 & 1.2 & 5.2 \\
\hline $7-12013$ & EB9017-02-3 & 1.850625 & 1.2 & 6.1 \\
\hline $7-12016$ & EB9017-02-6 & 1.847440 & 1.2 & 4.3 \\
\hline Average & & 1.8493 & & 5.3 \\
\hline Standard Deviation & & 0.0012 & & 0.7 \\
\hline
\end{tabular}

Chevron auriferous sample $\delta^{18} 0$ isotopic values

\begin{tabular}{ccccc}
\hline Sample Number & Sample Name & ${ }^{\mathbf{1 8}} \mathbf{O} /{ }^{\mathbf{1 6}} \mathbf{O}_{\text {meas }}$ & $\mathbf{1 \sigma}$ & $\boldsymbol{\delta}^{\mathbf{1 8}} \mathbf{O}_{\text {vSMOW }}(\mathbf{0}$ \\
\hline $7-12017$ & EB9017-1-1 & 1.843689 & 1.2 & 9.8 \\
$7-13016$ & EB9017-1-3 & 1.841475 & 1.2 & 8.5 \\
$7-13017$ & EB9017-1-4 & 1.845260 & 1.2 & 10.6 \\
$7-13018$ & EB9017-1-5 & 1.843465 & 1.2 & 9.6
\end{tabular}

$\begin{array}{lll}\text { Average } & 1.8435 & \mathbf{9 . 6}\end{array}$

Standard Deviation

0.0013

0.7

\begin{tabular}{|c|c|c|c|c|}
\hline \multicolumn{5}{|c|}{ Abino Barren sample $\delta^{18} 0$ isotopic values } \\
\hline $7-13010$ & ABU-51-1-1 & 1.838082 & 1.2 & 6.7 \\
\hline $7-13012$ & ABU-51-1-3 & 1.842111 & 1.2 & 8.9 \\
\hline 7-13o13 & ABU-51-1-4 & 1.842558 & 1.2 & 9.1 \\
\hline 7-13o14 & ABU-51-1-5 & 1.841808 & 1.2 & 8.7 \\
\hline
\end{tabular}

Average

1.8411

Standard Deviation

0.0018

\begin{tabular}{lrrrr}
\hline \multicolumn{4}{c}{ Abino auriferous sample } & $\delta^{18}$ O isotopic values \\
\hline $7-12031$ & ABU86-49-1 & 1.849299 & 1.2 & 5.3 \\
$7-12032$ & ABU86-49-2 & 1.846432 & 1.2 & 3.8 \\
$7-12034$ & ABU86-49-4 & 1.845316 & 1.2 & 3.2 \\
& & & & \\
Average & 1.8470 & & $\mathbf{4 . 1}$ \\
Standard Deviation & 0.0017 & & $\mathbf{0 . 9}$ \\
\hline
\end{tabular}


Table F7 (Cont) - Oxygen isotope values from quartz vein samples

Duchesne Barren sample $\delta^{18} 0$ isotopic values

\begin{tabular}{|c|c|c|c|c|}
\hline Sample Number & Sample Name & ${ }^{18} \mathrm{O} /{ }^{16} \mathrm{O}_{\text {meas }}$ & $1 \sigma$ & $\delta^{18} \mathrm{O}_{\text {vSMOW }}(\%)$ \\
\hline $7-12026$ & EB10048-2-1 & 1.856445 & 1.2 & 9.2 \\
\hline $7-12028$ & EB10048-2-3 & 1.854984 & 1.2 & 8.4 \\
\hline $7-12029$ & EB10048-2-4 & 1.853466 & 1.2 & 7.6 \\
\hline $7-12030$ & EB10048-2-5 & 1.855241 & 1.2 & 8.6 \\
\hline \multicolumn{2}{|l|}{ Average } & 1.8550 & & 8.5 \\
\hline \multicolumn{2}{|c|}{ Standard Deviation } & 0.0011 & & 0.6 \\
\hline \multicolumn{5}{|c|}{ Duchesne auriferous sample $\delta^{18} 0$ isotopic values } \\
\hline $7-17$ o7 & EB10048-03-2 & 1.811126 & 1.2 & 12.6 \\
\hline $7-17$ o8 & EB10048-03-3 & 1.808330 & 1.2 & 11.1 \\
\hline $7-17 \circ 9$ & EB10048-03-4 & 1.810389 & 1.2 & 12.2 \\
\hline $7-17$ o10 & EB10048-03-5 & 1.808878 & 1.2 & 11.4 \\
\hline \multicolumn{2}{|l|}{ Average } & 1.8097 & & 11.8 \\
\hline \multicolumn{2}{|c|}{ Standard Deviation } & 0.0011 & & 0.6 \\
\hline \multicolumn{5}{|c|}{ Cochenour auriferous sample $\delta^{18} 0$ isotopic values } \\
\hline 7-17o12 & CO20L-03-2 & 1.813346 & 1.2 & 13.9 \\
\hline $7-17 o 13$ & CO20L-03-3 & 1.811664 & 1.2 & 12.9 \\
\hline $7-17$ o14 & CO20L-03-4 & 1.811498 & 1.2 & 12.8 \\
\hline 7-17o15 & CO20L-03-5 & 1.811491 & 1.2 & 12.8 \\
\hline \multicolumn{2}{|l|}{ Average } & 1.8120 & & 13.1 \\
\hline \multicolumn{2}{|c|}{ Standard Deviation } & 0.0008 & & 0.4 \\
\hline
\end{tabular}

$\stackrel{N}{\stackrel{\omega}{~}}$
Tuckers Knob barren sample $\delta^{18} 0$ isotopic values

\begin{tabular}{|c|c|c|c|c|}
\hline Sample Number & Sample Name & ${ }^{18} \mathrm{O} /{ }^{16} \mathrm{O}_{\text {meas }}$ & $1 \sigma$ & $\delta^{18} \mathrm{O}_{\text {vSMOW }}$ \\
\hline $7-16020$ & SG11-171D-2 & 1.829960 & 1.2 & 5.7 \\
\hline $7-16021$ & SG11-171D-3 & 1.829628 & 1.2 & 5.5 \\
\hline $7-16022$ & SG11-171D-4 & 1.828550 & 1.2 & 4.9 \\
\hline $7-16023$ & SG11-171D-5 & 1.828681 & 1.2 & 5.0 \\
\hline \multicolumn{2}{|l|}{ Average } & 1.8292 & & 5.3 \\
\hline \multicolumn{2}{|c|}{ Standard Deviation } & 0.0006 & & 0.3 \\
\hline \multicolumn{5}{|c|}{ Tuckers Knob barren sample $\delta^{18} 0$ isotopic values } \\
\hline $7-12 o 21$ & SG11-175D2-2 & 1.837362 & 1.2 & 6.3 \\
\hline $7-12024$ & SG11-175D2-5 & 1.832453 & 1.2 & 3.6 \\
\hline $7-12025$ & SG11-175D2-6 & 1.839404 & 1.2 & 7.4 \\
\hline \multicolumn{2}{|l|}{ Average } & 1.8364 & & 5.8 \\
\hline \multicolumn{2}{|c|}{ Standard Deviation } & 0.0029 & & 1.6 \\
\hline
\end{tabular}


Appendix G

Sulphur Isotope Data for Figure 5.7 
Table G1 - Sulphur isotope data and references that were used to construct figure 5.XX

\begin{tabular}{|c|c|c|c|c|c|}
\hline Deposit & Age & $\begin{array}{l}\text { Minerals } \\
\text { Analyzed }\end{array}$ & $\delta^{34} S_{\text {CDT }}(\%)$ & Reference & $\begin{array}{c}\text { Rank on Figure } \\
\text { (top to bottom) }\end{array}$ \\
\hline East Bay Trend, Red Lake, Canada & Archean & Pyrite & $2.17-5.27$ & This Study & 1 \\
\hline RLGM, Red Lake, Canada & Archean & $\begin{array}{c}\text { Pyrite, } \\
\text { Pyrrhotite }\end{array}$ & $0.8-6.2$ & Lavigne \& Cocket, 1982 & 2 \\
\hline Val D’Or, Abitibi, Canada & Archean & Pyrite & $0.6-6$ & Beaudoin \& Pitre, 2005 & 3 \\
\hline Hemlo, Ontario, Canada & Archean & Pyrite & $-17.5-7$ & Cameron \& Hattori, 1985 & 4 \\
\hline Con-Giant, Yellowknife, Canada & Archean & Pyrite & $0-5$ & Wanless et al., 1960 & 5 \\
\hline Meguma, Nova Scotia, Canada & Paleozoic & Pyrite & $6-12$ & Kontak et al., 1990 & 6 \\
\hline Homestake, South Dakota, USA & Archean & $\begin{array}{c}\text { Pyrite, } \\
\text { Arsenopyrite }\end{array}$ & $5-10$ & Zairi et al., 1978 & 7 \\
\hline Juneau Belt, Alaska, USA & Paleozoic & Pyrite & $-7--5$ & Goldfarb et al., 1991 & 8 \\
\hline Carlin Deposits, Nevada, USA & Mesozoic & Pyrite & $-1-4$ & Kesler et al., 2005 & 9 \\
\hline Oriental Mine, Nevada, USA & Mesozoic & Pyrite & $-0.8-5.5$ & Bohlke, et al., 1988 & 10 \\
\hline Eastern Goldfields, Yilgarn, Australia & Archean & Pyrite & $-4-4$ & Hodkiewicz et al., 2008 & 11 \\
\hline Maratoto/Golden Cross, New Zealand & Cenozoic & Pyrite & $2-5.5$ & Kusakabe, 1974 & 12 \\
\hline
\end{tabular}


Appendix $\mathrm{H}$

Oxygen Isotope Data for Figure 5.11 
Table H1 - Oxygen isotope data and references that were used to construct figure 5.11

\begin{tabular}{|c|c|c|c|c|c|}
\hline Deposit & Age & Deposit Style & $\delta^{18} \mathrm{O}_{\text {vsmow }}(\%)$ & Reference & $\begin{array}{l}\text { Rank on Figure } \\
\text { (top to bottom) }\end{array}$ \\
\hline $\begin{array}{c}\text { East Bay Trend, Red Lake, Canada } \\
\text { Auriferous Quartz }\end{array}$ & Archean & Mesothermal? & $9.6-13.1$ & This Study & 1 \\
\hline $\begin{array}{l}\text { East Bay Trend, Red Lake, Canada } \\
\text { Auriferous Quartz-Tourmaline }\end{array}$ & Archean & Mesothermal? & $17.2-17.3$ & This Study & 1 \\
\hline Buffalo Deposit, Red Lake, Canada & Archean & Mesothermal & $11.4-11.9$ & Chi et al, 2010 & 2 \\
\hline Ashanti Gold Mine, Ghana & Proterozoic & Mesothermal & $14.4-17.4$ & Yao et al., 2000 & 3 \\
\hline $\begin{array}{c}\text { Dufferin Deposit, Meguma, Nova Scotia, } \\
\text { Canada }\end{array}$ & Paleozoic & Mesothermal & $12.3-16.7$ & Kontak et al, 2011 & 4 \\
\hline Juneau Belt, Alaska, USA & Paleozoic & Mesothermal & $15.2-20.8$ & Goldfarb et al, 1991 & 5 \\
\hline Mother Lode, California, USA & Archean & Mesothermal & $15-17.5$ & Weir \& Kerrick, 1987 & 6 \\
\hline Warrawoona syncline, Australia & Archean & Mesothermal & $11.5-16.6$ & Thébaud et al, 2005 & 7 \\
\hline Yilgarn District, Australia & Archean & Mesothermal & $10.8-12.4$ & Knight et al., 2000 & 8 \\
\hline Hemlo Deposit, Ontario, Canada & Archean & Mesothermal & $13.9-17.7$ & Kuhns et al. 1994 & 9 \\
\hline Klondike District, Yukon, Canada & Archean & Mesothermal & $12.4-19.3$ & Rushton et al, 1993 & 10 \\
\hline Con Giant, Yellowknife, NWT, Canada & Archean & Mesothermal & $11.7-14$ & Van Hees et al., 1999 & 11 \\
\hline Abitibi Belt, Sigma deposit & Archean & Mesothermal & $11-11.3$ & Neumayr, et al, 2007 & 12 \\
\hline Abitibi Belt, Cartier Malartic deposit & Archean & Mesothermal & $11.8-12.3$ & Neumayr, et al, 2007 & 13 \\
\hline
\end{tabular}


Table H1 (Cont) - Oxygen isotope data and references that were used to construct figure 5.11

\begin{tabular}{|c|c|c|c|c|c|}
\hline Deposit & Age & Deposit Style & $\delta^{18} O_{\text {vsmow }}(\%)$ & Reference & $\begin{array}{l}\text { Rank on Figure } \\
\text { (top to bottom) }\end{array}$ \\
\hline Abitibi Belt, Astoria deposit & Archean & Mesothermal & $14.4-15.1$ & Neumayr, et al, 2007 & 14 \\
\hline Golden Cross, New Zealand & Cenozoic & Epithermal & $7.0-11.7$ & De Ronde \& Blattner, 1988 & 15 \\
\hline Hauraki Goldfield, New Zealand & Cenozoic & Epithermal & $4.1-9.7$ & Simpson \& Mauk, 2011 & 16 \\
\hline Comstock Lode, Nevada, USA & Cenozoic & Epithermal & $1.5-3$ & Taylor, 1973 & 17 \\
\hline Sleeper Deposit, Nevada, USA & Cenozoic & Epithermal & $8.6-13.7$ & Saunders et al, 2008 & 18 \\
\hline Okanogan, British Columbia, Canada & Mesozoic & Epithermal & $0.8-2.8$ & Zhang et al, 1989 & 19 \\
\hline Toodooggone, British Columbia, Canada & Mesozoic & Epithermal & $6.1-12.6$ & Diakow et al, 1991 & 20 \\
\hline Mount Skukum, Yukon, Canada & Cenozoic & Epithermal & $3.5-4.3$ & McDonald, 1990 & 21 \\
\hline Hishikari, Japan & Cenozoic & Epithermal & $7-9.5$ & Faure et al, 2002 & 22 \\
\hline Creede, Colorado, USA & Cenozoic & Epithermal & $3-10$ & Rye, et al., 1988 & 23 \\
\hline
\end{tabular}


Appendix I

SHRIMP II Geochronology Data 
Table I1 - Summary of SHRIMP U-Pb titanite data from the East Bay Trend, Red Lake, Ontario

\begin{tabular}{|c|c|c|c|c|c|c|c|c|c|c|c|c|c|c|c|c|c|}
\hline \multirow{2}{*}{$\begin{array}{l}\text { Spot } \\
1-1.1\end{array}$} & \multirow{2}{*}{$\begin{array}{c}\begin{array}{c}\% \\
{ }^{206} \mathbf{P b}_{\mathrm{c}}\end{array} \\
7.57\end{array}$} & \multirow{2}{*}{$\begin{array}{c}\mathbf{p p m} \\
\mathbf{U} \\
39\end{array}$} & \multirow{2}{*}{$\begin{array}{c}\text { ppm } \\
\text { Th } \\
15\end{array}$} & \multirow{2}{*}{$\begin{array}{r}{ }^{238} \mathrm{U} \\
\mathbf{0 . 4 0}\end{array}$} & \multirow{2}{*}{$\begin{array}{c}\underset{{ }^{006} \mathrm{~Pb}^{*}}{ } \\
17.1\end{array}$} & \multicolumn{2}{|c|}{$\begin{array}{c}\text { (1) } \\
{ }^{206} \mathrm{~Pb} /{ }^{238} \mathrm{U} \\
\text { Age }\end{array}$} & \multicolumn{2}{|c|}{$\begin{array}{c}(1) \\
{ }^{207} \mathrm{~Pb} /{ }^{206} \mathrm{~Pb} \\
\text { Age }\end{array}$} & \multirow{2}{*}{$\begin{array}{c}\% \\
\text { Discordant } \\
8\end{array}$} & \multirow{2}{*}{$\begin{array}{c}{ }^{(1)}{ }^{207} \mathrm{~Pb}^{*} / \\
{ }^{206} \mathrm{~Pb}^{*} \\
0.1854\end{array}$} & \multirow{2}{*}{$\begin{array}{r} \pm \% \\
3.3\end{array}$} & \multirow{2}{*}{$\begin{array}{c}{ }^{(1)}{ }^{207} \mathrm{~Pb}^{*} \\
{ }^{235} \mathrm{U} \\
12.01\end{array}$} & \multirow{2}{*}{$\begin{array}{r} \pm \% \\
4\end{array}$} & \multirow{2}{*}{$\begin{array}{c}{ }^{(1)} \\
{ }^{206} \mathbf{P b}^{*} \\
/^{238} \mathbf{U}\end{array}$} & \multirow{2}{*}{\begin{tabular}{r|} 
$\pm \%$ \\
2.2
\end{tabular}} & \multirow{2}{*}{$\begin{array}{c}\begin{array}{c}\text { err } \\
\text { corr }\end{array} \\
.557\end{array}$} \\
\hline & & & & & & 2483 & \pm 46 & 2702 & \pm 55 & & & & & & & & \\
\hline $1-1.2$ & 7.10 & 47 & 17 & 0.38 & 21.5 & 2588 & \pm 46 & 2694 & $\pm \mathbf{5 2}$ & 4 & 0.1845 & 3.2 & 12.57 & 3.8 & 0.494 & 2.1 & .559 \\
\hline $1-1.3$ & 8.09 & 38 & 15 & 0.42 & 16.4 & 2443 & \pm 56 & 2728 & \pm 70 & 10 & 0.1884 & 4.3 & 11.97 & 5.1 & 0.461 & 2.8 & .541 \\
\hline $1-1.4$ & 17.59 & 32 & 13 & 0.41 & 16.2 & 2559 & \pm 94 & 2701 & \pm 270 & 5 & 0.185 & 16 & 12.4 & 17 & 0.487 & 4.5 & .265 \\
\hline $2-1.1$ & 6.36 & 46 & 19 & 0.43 & 20.4 & 2528 & \pm 43 & 2715 & \pm 51 & 7 & 0.1869 & 3.1 & 12.37 & 3.7 & 0.4803 & 2.1 & .556 \\
\hline $2-1.2$ & 6.56 & 35 & 12 & 0.35 & 16.6 & 2680 & \pm 54 & 2695 & \pm 53 & 1 & 0.1846 & 3.2 & 13.12 & 4 & 0.516 & 2.5 & .610 \\
\hline $2-1.3$ & 5.24 & 56 & 13 & 0.25 & 26 & 2674 & \pm 46 & 2707 & \pm 58 & 1 & 0.186 & 3.5 & 13.18 & 4.1 & 0.514 & 2.1 & .508 \\
\hline $2-1.4$ & 6.47 & 34 & 12 & 0.36 & 16.2 & 2689 & \pm 51 & 2697 & \pm 56 & $\mathbf{0}$ & 0.1848 & 3.4 & 13.19 & 4.1 & 0.518 & 2.3 & .568 \\
\hline $2-1.5$ & 7.36 & 29 & 11 & 0.39 & 13.7 & 2633 & \pm 54 & 2745 & \pm 60 & 4 & 0.1904 & 3.6 & 13.24 & 4.4 & 0.504 & 2.5 & .569 \\
\hline $2-1.6$ & 5.90 & 50 & 18 & 0.38 & 21.9 & 2528 & \pm 44 & 2709 & \pm 48 & 7 & 0.1862 & 2.9 & 12.33 & 3.6 & 0.4802 & 2.1 & .583 \\
\hline $2-1.7$ & 6.68 & 42 & 15 & 0.37 & 18.1 & 2488 & \pm 46 & 2699 & \pm 55 & 8 & 0.1851 & 3.3 & 12.02 & 4 & 0.471 & 2.2 & .556 \\
\hline
\end{tabular}

Errors are $1 \sigma ; \mathrm{Pb}_{\mathrm{c}}$ and $\mathrm{Pb}^{*}$ indicate the common and radiogenic portions, respectively.

Error in Standard calibration was $0.52 \%$ (not included in above errors but required when comparing data from different mounts).

(1) Common $\mathrm{Pb}$ corrected using measured ${ }^{204} \mathrm{~Pb}$. 